UNIVERSIDADE DE BRASÍLIA

INSTITUTO DE CIÊNCIAS BIOLÓGICAS

DEPARTAMENTO DE FITOPATOLOGIA

PROGRAMA DE PÓS-GRADUAÇÃO EM FITOPATOLOGIA

Resistência induzida por agentes bióticos e abióticos na interação Oryza sativa-Magnaporthe oryzae

Eugenio Miranda Sperandio

Brasília - DF 


\title{
RESISTÊNCIA INDUZIDA POR AGENTES BIÓTICOS E ABIÓTICOS NA INTERAÇÃO ORYZA SATIVA-MAGNAPORTHE ORYZAE
}

\author{
Tese apresentada à \\ Universidade de Brasília \\ como requisito parcial para \\ a obtenção do título de \\ Doutor em Fitopatologia \\ pelo Programa de Pós- \\ graduação em Fitopatologia.
}

\section{Orientador}

Professor Dr. Helson Mário Martins do Vale

\section{Co-orientador}

Dra. Marta Cristina Corsi de Filippi

\section{Brasília - Distrito Federal}




\section{FICHA CATALOGRÁFICA}

SPERANDIO, Eugenio Miranda.

Resistência induzida por agentes bióticos e abióticos na interação Oryza sativa-Magnaporthe oryzae.

Brasília, 2016.

Número de páginas p.: 204

Tese de doutorado. Programa de Pós-graduação em Fitopatologia,

Universidade de Brasília, Brasília.

1. Indução de resistência - crosstalk

I. Universidade de Brasília. PPG/FIT.

II. Resistência induzida por agentes bióticos e abióticos na interação Oryza sativa-Magnaporthe oryzae. 
Aos meus pais e à minha família.

Dedico. 


\section{AGRADECIMENTOS}

Agradeço primeiramente a Deus e aos meus companheiros dos dois lados da vida que me ajudaram muito nessa etapa de minha vida.

Aos meus Pais, Ademir Sperandio e Olenice Dias de Miranda, meu amado porto seguro. Aos meus amados irmãos, Ademir Sperandio Júnior, Kellen Miranda, Gizeli Miranda de Oliveira, Luciane Sperandio, Lizandra Dias de Miranda e Luziano Batista de Miranda. À minha querida família que tanto amo. Aos companheiros da Comunidade Espírita Irmão José Martins pelos bons momentos de aprendizado e convívio antes, durante e após essa jornada. Aos queridos amigos e companheiros do Mocizade.

À minha namorada Leilane pelo apoio e compreensão.

Aos meus amigos que me toleraram esse tempo todo, sempre escutando minhas desculpas de "não posso, tenho experimento pra fazer".

À Cristina pelos ensinos e atenção a mim ministrados durante todo esse tempo.

Ao orientador e amigo Helson pela orientação e paciência nesse tempo todo de mestrado e doutorado. Foram muitos os momentos de aprendizado.

Aos amigos William Soares, Sandro Coelho e Alaerson Geraldine e aos demais colegas de doutorado e do Departamento de Fitopatologia - UnB.

Aos amigos da Embrapa, Fábio José Gonçalves, Stella Cristina, Maythsulene, Amanda, Thatiane, Bruna Alícia, Mythali, Rejanne e Wendell. Ao pessoal da Embrapa, Lívia, Elder, Mônica, Dra Valácia, Dra Anna Cristina, em especial pelo apoio do Márcio Vinícius. Ao pessoal do apoio técnico.

Aos brothers Fabyano Lopes e Andrei Steindorff pela ajuda que me deram nos momentos cruciais da reta final do meu doutorado. Ao amigo Gabriel Alves, muito obrigado pela ajuda, paciência e ensinamentos que me passou. Sua colaboração foi impressindível para o sucesso de minha tese. Ao Professor Robert por abrir as portas do seu laboratório a mim.

À Professora Letícia e à Elienai.

À Universidade de Brasília pela oportunidade de estudo. À CAPES e ao CNPq pela conseção da bolsa de doutorado.

À Fundação de Apoio à Pesquisa do Distrito Federal - FAPDF pelo financiamento do projeto ( $\left.\mathrm{n}^{\mathrm{o}}: 0193.000926 / 2015\right)$.

A todos que contribuíram com esse trabalho, por mais singelo que tenha sido a ajuda, muito obrigado! 
Trabalho realizado junto ao Departamento de Fitopatologia do Instituto de Ciências Biológicas da Universidade de Brasília, sob orientação do Professor Helson Mário Martins do Vale, com apoio da EMBRAPA Arroz e Feijão, FAPDF e CNPq.

\section{MECANISMOS DE RESISTÊNCIA E EXPRESSÃO GÊNICA INDUZIDOS NA INTERAÇÃO ORYZA SATIVA-MAGNAPORTHE ORYZAE.}

\section{EUGENIO MIRANDA SPERANDIO}

TESE APROVADA EM por:

Dra. Gisele Pereira Domiciano

Examinador externo

Profa. Dra. Eliane Ferreira Noronha - CEL - IB - UnB

Examinador externo

Prof. Dr. Robert Neil Gerard Miller - CEL - IB - UnB

Examinador interno

Profa. Dra. Marisa Alvares S. V. Ferreira - FIT - IB- UnB

Examinador interno

Profa. Dr. Helson Mário Martins do Vale - FIT - IB- UnB Orientador

BRASÍLIA - DISTRITO FEDERAL

BRASIL 


\section{SUMÁRIO}

LISTA DE TABELAS.

Página

LISTA DE FIGURAS

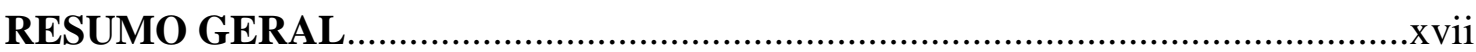

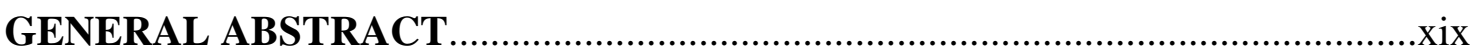

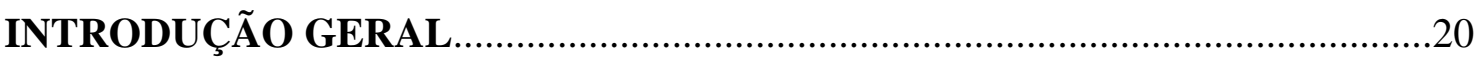

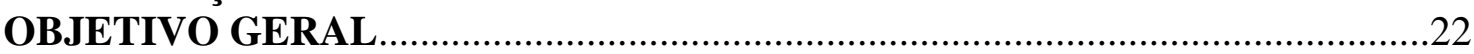

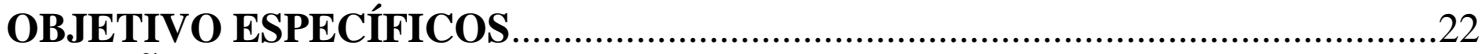

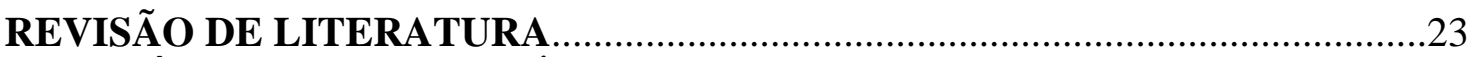

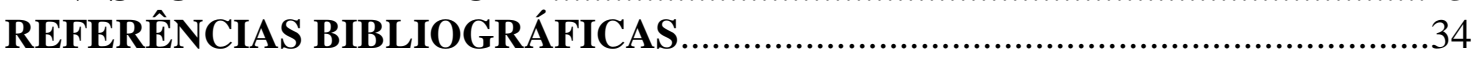

CAPÍTULO 1: Artigo: Evaluation of rhizobacteria in upland rice in Brazil: growth promotion and induced defense responses interaction against leaf blast (Magnaporthe

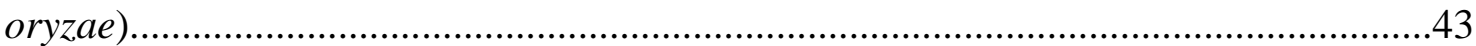

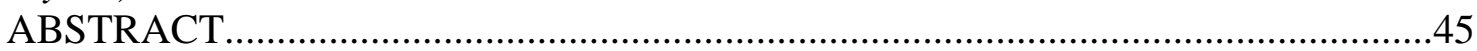

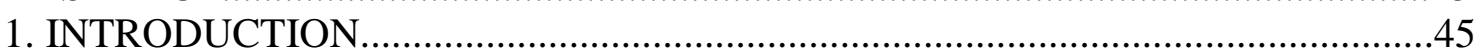

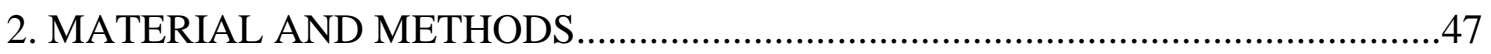

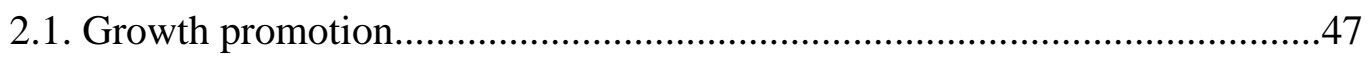

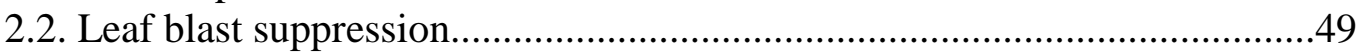

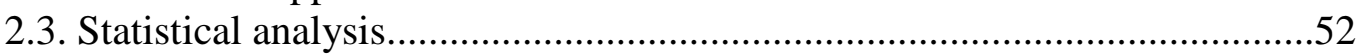

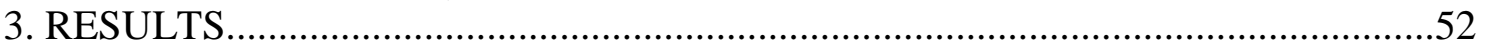

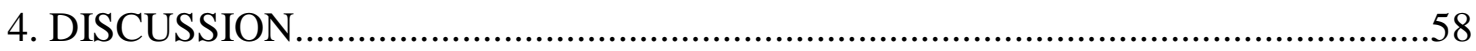

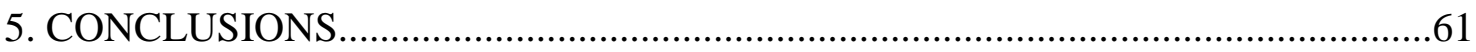

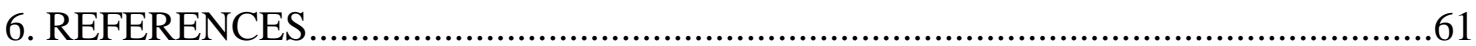

CAPÍTULO 2: Indução de resistência à brusone foliar em arroz por isolados

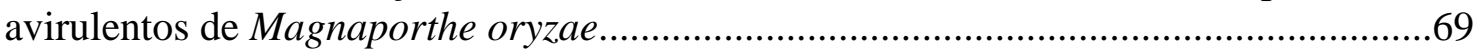

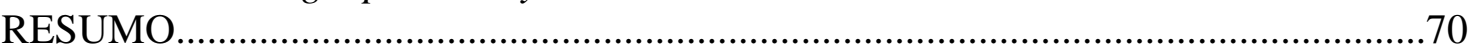

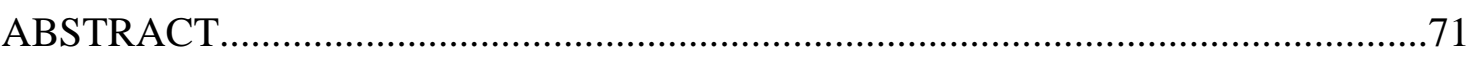

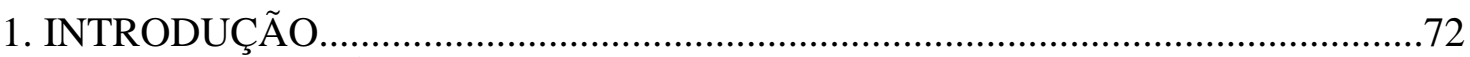

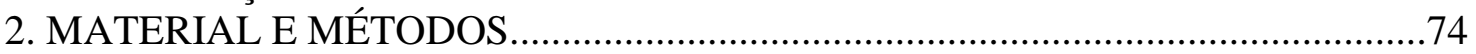

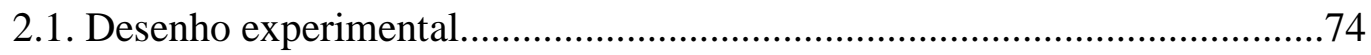

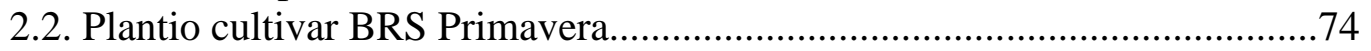

2.3. Seleção de isolados de Magnaporthe oryzae ...............................................75

2.4. Indução de resistência usando isolado avirulento de $M$. oryzae ....................75

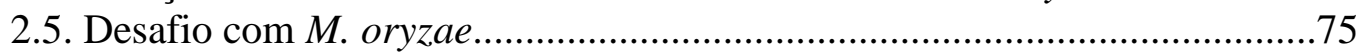

2.6. Determinação da atividade das enzimas $\beta-1,3$ glucanase, peroxidase, fenilalanina amônia-liase, quantificação de compostos fenólicos e teor de ácido salicílico em plantas de arroz.............................................................................76

2.7. Microscopia das folhas de arroz tratadas com isolado avirulento de $M$.

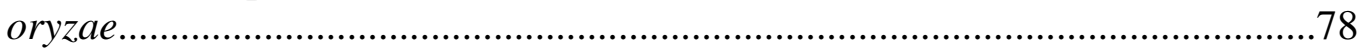

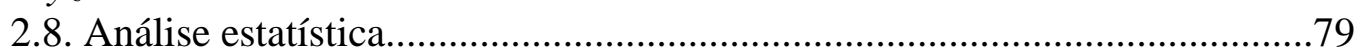

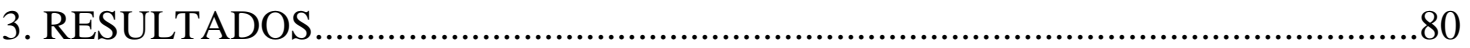

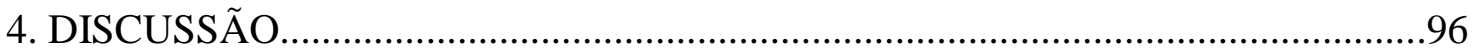

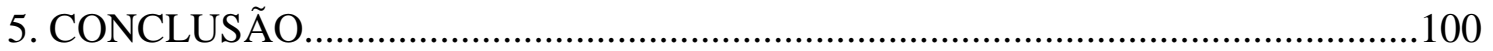

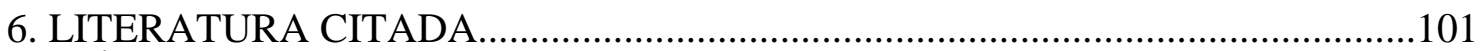

CAPÍTULO 3: Indução de resistência em arroz por meio de indutores abióticos para

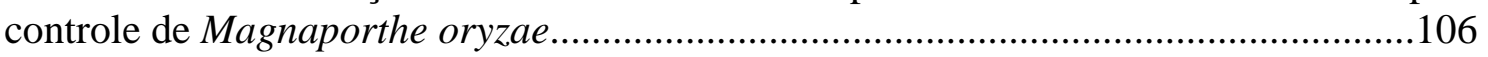

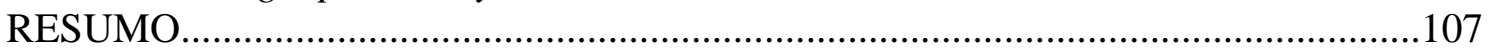

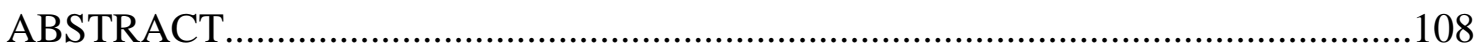

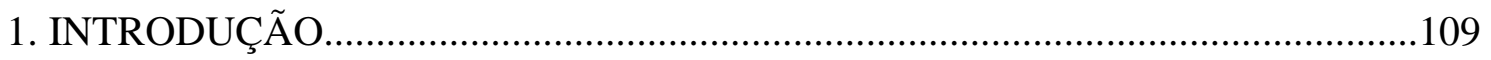




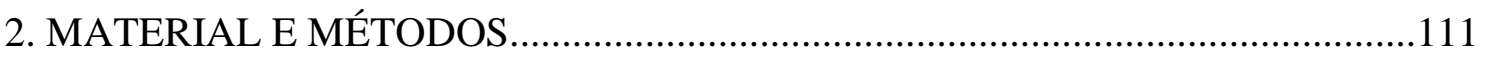

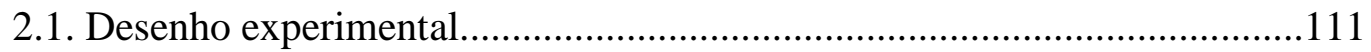

2.2. Plantio cultivar BRS Primavera..............................................................111

2.3. Aplicação das moléculas químicas de ASM e JA em plantas de arroz para controle de brusone...................................................................................... 11

2.4. Desafio com M. oryzae ......................................................................111

2.5. Determinação da atividade das enzimas $\beta-1,3$ glucanase, lipoxigenase, peroxidase, fenilalanina amônia-liase, quantificação de compostos fenólicos e teor de ácido salicílico em plantas de arroz......................................................112

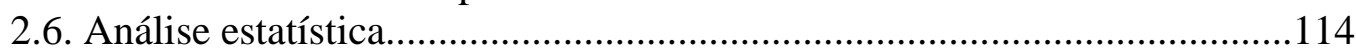

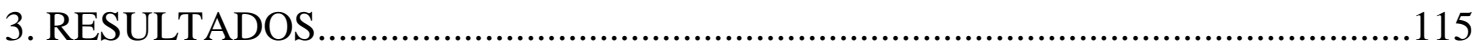

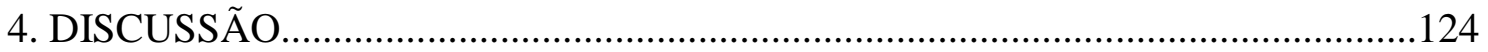

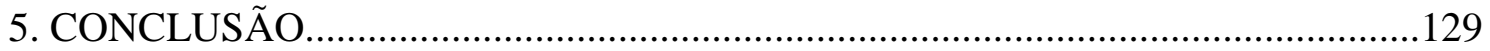

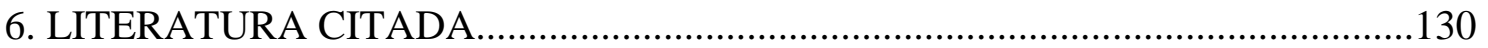

CAPÍTULO 4: Comparação do trascriptoma de arroz de terras altas induzidos com rizobactéria promotora de crescimento Serratia sp. e isolados avirulento e virulento de

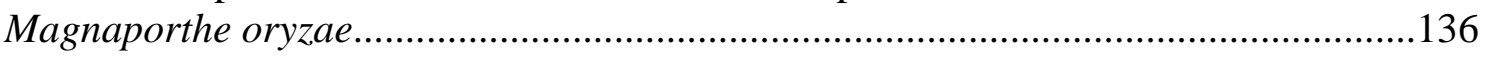

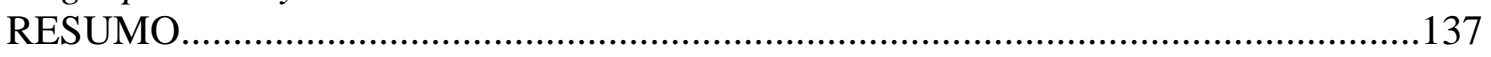

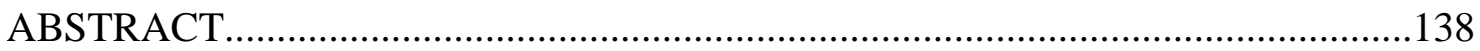

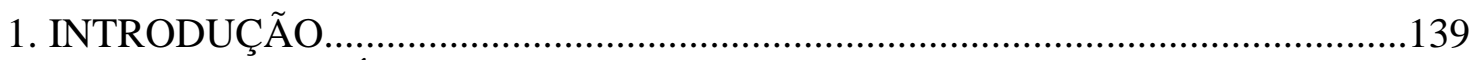

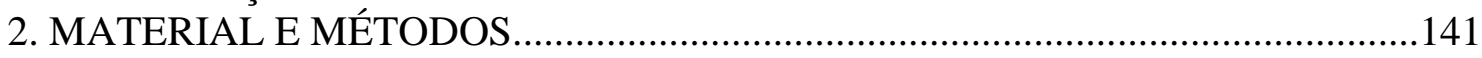

2.1. Produção de suspensão da PGPR BRM 32114 ..........................................141

2.2. Produção de inóculo do isolado avirulento de $M$. oryzae ............................141

2.3. Desafio das plantas de arroz com isolado virulento de M. oryzae..............141

2.4. Extração de RNA................................................................................... 142

2.5. Sequenciamento de RNA e análise de bioinformática................................142

2.6. Validação de RNAseq pela reação em cadeia da polimerase via transcriptase

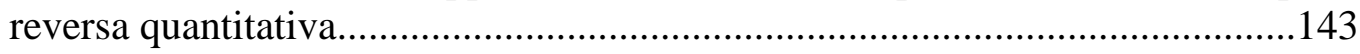

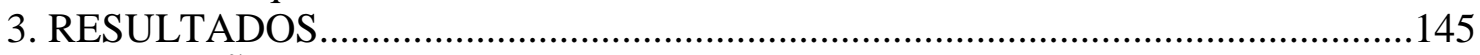

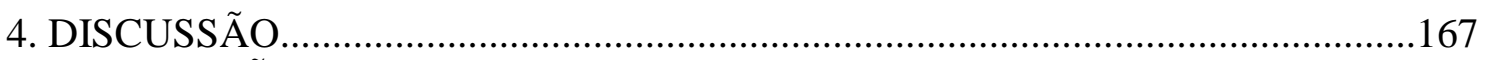

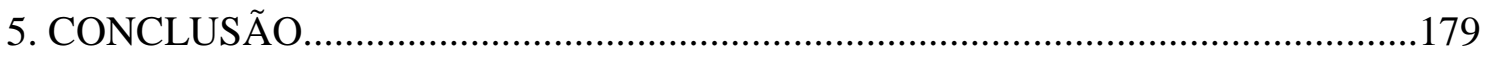

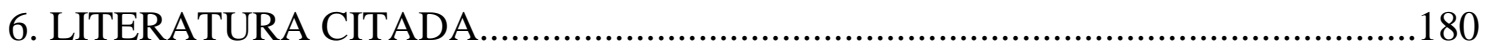

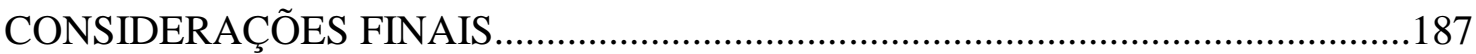

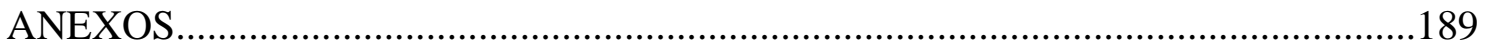




\section{LISTA DE TABELAS}

Página

CAPÍTULO 1: Evaluation of rhizobacteria in upland rice in Brazil: growth promotion and induced defense responses interaction against leaf blast (Magnaporthe oryzae).....41

Tabela 1. Length and biomass of roots and shoots, leaf area and Nitrate Reductase activity in leaves of rice plants treated with rhizobacteria BRM 32110 and BRM 32114.

Tabela 2. Table 2. proteins related to pathogenesis activity of $\beta$-1,3-glucanase (Glu), lipoxygenase (LOX), phenylalanine ammonia lyase (PAL), peroxidase (POX) and salicylic acid contents (SA), in upland rice plants treated with the rhizobacteria followed, or not, by challenge inoculation with $M$. oryzae 54

Tabela 3. Correlation matrix of variables related to induced resistance in rice to control rice blast (Magnaporthe oryzae) by BRM 32114 and BRM 32110 isolates and dimensions of principal component analysis with significance of $p<$ 0.05 . .56

CAPÍTULO 2: Indução de resistência à brusone foliar em arroz por isolados avirulentos de Magnaporthe oryzae. .68

Tabela 1. Atividade das proteínas relacionadas à patogênese $\beta-1,3$ glucanase (GLU), fenilalanina amônia-liase (PAL), peroxidase (POX), compostos fenólicos (CF), teor de ácido salicílico (SA) e severidade de brusone foliar em plantas de arroz de terras altas tratadas com as isolado avirulento seguidas ou não de inoculação desafiante com isolado virulento de M. oryzae PY10900......81 Tabela 2. Matriz de correlação das variáveis relacionadas a indução de resistência em arroz para controle da brusone foliar (Magnaporthe oryzae) por JA, ASM e JA+ASM e dimenções da análise de componentes principais com significância de $p<0.05$

CAPÍTULO 3: Indução de resistência à brusone foliar em arroz por meio de indutores abióticos para controle de Magnaporthe oryzae. 104

Tabela 1. Atividade das proteínas relacionadas à patogênese $\beta-1,3$ glucanase (GLU), fenilalanina amônia-liase (PAL), lipoxigenase (LOX), peroxidase (POX), compostos fenólicos (CF), teor de ácido salicílico (SA) e severidade de brusone foliar (SBF) em plantas de arroz de terras altas tratadas com as rizobactérias seguidas ou não de inoculação desafiante com M. oryzae. 116 
Página

Tabela 2. Matriz de correlação das variáveis relacionadas a indução de resistência em arroz para controle da brusone foliar (Magnaporthe oryzae) por JA, ASM e JA+ASM e dimenções da análise de componentes principais com significância de $p<0.05$ .121

CAPÍTULO 4: Comparação do trascritoma de arroz de terras altas induzidos com rizobactéria promotora de crescimento Serratia sp., M. oryzae avirulento e M. oryzae virulento. 134

Tabela 1. Descrição das bibliotecas sequenciadas (RNA-seq) de plantas de arroz.

ANEXOS

Tabela 1. Oligos utilizados na validação dos dados de RNAseq via qRTPCR.

Tabela 2.Genes diferencialmente expressos (DEG) relacionados com ácido salicílico (SA).

Tabela 3. Genes diferencialmente expressos (DEG) relacionados com ácido jasmônico (JA). 185

Tabela 4. Genes diferencialmente expressos (DEG) relacionados com Etileno (ET).

Tabela 5. Genes diferencialmente expressos (DEG) relacionados proteínas relacionadas à patogênese (PRP) 188

Tabela 6. Genes diferencialmente expressos (DEG) da família de fatores de transcrição WRKY

Tabela 6. Genes diferencialmente expressos (DEG) da família proteínas quinases ativadas por mitógenos (MAPK, MAPKK e MAPKKK)

Tabela 7. Genes diferencialmente expressos (DEG) relacionados com genes de resistência $(\mathrm{R})$.

Tabela 8. Genes diferencialmente expressos (DEG) relacionados com síntese de fitoalexinas.

Tabela 9. Genes diferencialmente expressos (DEG) do citocromo P450 195

Tabela 10.Genes diferencialmente expressos (DEG) de genes envolvidos no crosstalk das vias hormonais 


\section{LISTA DE FIGURAS}

Página

CAPÍTULO 1: Evaluation of rhizobacteria in upland rice in Brazil: growth promotion and induced defense responses interaction against leaf blast (Magnaporthe oryzae).....41

Figura 1. Root growth of rice seedling 10 days after planting. Seeds were microbiolized with water (A and D), with isolate BRM 32110 (B and E) and BRM 32114 ( $\mathrm{C}$ and $\mathrm{F}$ ) and transferred to test tubes containing water-agar medium $(0.8 \% \mathrm{w} / \mathrm{v})(\mathrm{bar}=5 \mathrm{~mm})$ .66

Figura 2. Area under the disease progress curve (AUDPC) of three different treatments: control (diamond): seeds microbiolized and plants drenched with water only and sprayed inoculated with $M$. oryzae conidial suspension; BRM32110 (square): seeds microbiolized and plants drenched with BRM 32110 suspension and sprayed inoculated with $M$. oryzae conidial suspension; BRM32114 (triangle): seeds microbiolized and plants drenched with BRM 32114 suspension and sprayed inoculated with $M$. oryzae conidial suspension. The bars above and below show maximum and minimum values of disease severity, respectively. Curves followed by the same letter are not statistically different by Tukey $(p=0,05)$ test. .66

Figura 3. Principal Component Analyses plot with induced resistance variables investigated for control of rice blast $(M$. oryzae) by plant growth-promoting rhizobacteria.

CAPÍTULO 2: Indução de resistência à brusone foliar em arroz por isolados avirulentos de Magnaporthe oryzae.

Figura 1. Severidade de brusone foliar em folhas de arroz. Plantas controle (A), induzidas com PY10749 (B), induzidas com PY10749 e desafiadas com PY10900 (C) e testemunha PY10900 (D). .79

Figura 2. PCA biplot com variaveis de investigadas na indução de resistência de plantas de arroz com isolado avirulento de $M$. oruzae de acordo com os dois primeiros componentes. A-correlação entre as variáveis; B-distribuição dos dados.

Figura 3. Observação de microscopia eletrônica de varredura. Folha de arroz inoculada com isolado virulento de M. oryzae PY10900 24h após o desafio (3DPI). A: apressório; GT: tubo germinativo; C: conídio. 
Página

Figura 4. Observação de microscopia eletrônica de varredura. Folha de arroz induzida com isolado avirulento PY10749 e inoculada com M. oryzae virulento 48h após o desafio (4DPI). A: apressório; GT: tubo germinativo. .88

Figura 5. Observação de microscopia eletrônica de varredura de folha de arroz tratadas com $\mathrm{H}_{2} \mathrm{O}$ (controle). E: estômato. .89

Figura 6. Microscopia óptica de luz em plantas de arroz. Corte transversal de folhas de plantas induzidas com M. oryzae avirulento (PY10749) e desafiada com M. oryzae virulento (PY10900). BC: células buliformes; UE: epiderme superior; LE: epiderme inferior; PC: parênquima clorofiliano; V: vesículas com conteúdo citoplasmático; HR: reação de hipersensibilidade - células mortas.....90 Figura 7. Microscopia óptica de luz em plantas de arroz. Corte transversal de folhas de plantas induzidas com M. oryzae avirulento (PY10749). AP: parênquima aquífero; $\mathrm{BC}$ : células buliformes; $\mathrm{CP}$ : parênquima clorofiliano; $\mathrm{CT}$ : células propriamente ditas; F: fibras; V: vesículas com conteúdo citoplasmático; P: floema; X: xilema.

Figura 8. Microscopia óptica de luz em plantas de arroz. Corte transversal em folhas de plantas desafiadas com PY10900 (testemunha). BC: células buliformes; PC: célula plasmolizada; NT: tecido necrosado.

Figura 9. Observação de microscopia óptica de epifluorescência. A e B: plantas de arroz induzidas com isolado PY10749 e desafiados com PY10900 mostrando células epidérmicas com flurescência indicando deposição de calose (CD) ao redor de áreas lesionadas (L); C: plantas tratadas com PY10900 (E=estômatos); D: plantas controle $\left(\mathrm{H}_{2} \mathrm{O}\right)$ com tricomas $(\mathrm{T})$

CAPÍTULO 3: Indução de resistência à brusone foliar em arroz por meio de indutores abióticos para controle de Magnaporthe oryzae. 104

Figura 1. Severidade de brusone foliar em folhas de arroz. Tratamento controle $\left(\mathrm{H}_{2} \mathrm{O}\right)(\mathrm{A})$. B-E: plantas induzidas com ASM (B), induzidas com JA+ASM (C), induzidas com JA (D) e testemunha (PY10900) (E) 114

Figura 2. PCA biplot com variaveis de investigadas na indução de resistência de plantas de arroz com JA, ASM e JA+ASM desafiadas com M. oruzae de acordo com os dois primeiros componentes. A-correlação entre as variáveis; Bdistribuição dos dados. 
Página

CAPÍTUlO 4: Comparação do trascritoma de arroz de terras altas induzidos com rizobactéria promotora de crescimento Serratia sp., M. oryzae avirulento e M. oryzae virulento.

Figura 1. Gráfico de média de expressão versus $\log ^{2}$ fold change (MA-plots). Mudanças transcricionais estão presentes nas plantas de arroz após a indução. Valores de média de expressão normalizadas são plotadas contra $\log 2$ fold changes. Genes com um FDR < 0.05 são plotados em vermelho. 144

Figura 2. Diagrama de DEGs modulados pelos respectivos agentes indutores. Os DEGs encontrados 24hs após a indução 145

Figura 3. Mudanças no perfil de DEGs entre as três amostras 145

Figura 4. Diagrama de Venn ilustrando a relação entre os genes modulados nas condições PGPR, AVR e VIR 146

Figura 5. Clusterização e heat map da expressão de genes da biossíntese de SA e genes responsivo a SA modulados segundo os diferentes tratamentos. A escala de cor indica o valor de expressão. O heat map foi gerado no programa $\mathrm{R}$ v.3.2.0 utilizando o pacote heatmap.2. Análise com distância euclidiana e usando o algorítimo UPGMA. O agrupamento do genes foi baseada na semelhança do padrão de expressão.

Figura 6. Clusterização e heat map da expressão de genes da biossíntese do JA e genes reponsivos a JA modulados segundo os diferentes tratamentos. A escala de cor indica o valor de expressão. O heat map foi gerado no programa $\mathrm{R}$ v.3.2.0 utilizando o pacote heatmap.2. Análise com distância euclidiana e usando o algorítimo UPGMA. O agrupamento do genes foi baseada na semelhança do padrão de expressão.

Figura 7. Clusterização e heat map da expressão de genes da biossíntese de etileno (ET) e de genes responsivos ao ET modulados segundo os diferentes tratamentos. A escala de cor indica o valor de expressão. O heat map foi gerado no programa R v.3.2.0 utilizando o pacote heatmap.2. Análise com distância euclidiana e usando o algorítimo UPGMA. O agrupamento do genes foi baseada na semelhança do padrão de expressão.

Figura 8. Clusterização e heat map da expressão de genes de proteínas relacionadas a patogênese (PRP) modulados segundo os diferentes tratamentos. A escala de cor indica o valor de expressão. O heat map foi gerado no programa 
Página

R v.3.2.0 utilizando o pacote heatmap.2. Análise com distância euclidiana e usando o algorítimo UPGMA. O agrupamento do genes foi baseada na semelhança do padrão de expressão

Figura 9. Clusterização e heat map da expressão de genes fatores de trasncrição WRKY modulados segundo os diferentes tratamentos. A escala de cor indica o valor de expressão. O heat map foi gerado no programa R v.3.2.0 utilizando o pacote heatmap.2. Análise com distância euclidiana e usando o algorítimo UPGMA. O agrupamento do genes foi baseada na semelhança do padrão de expressão.

Figura 10. Clusterização e heat map da expressão de genes MAP quinases modulados segundo os diferentes tratamentos. A escala de cor indica o valor de expressão. O heat map foi gerado no programa $\mathrm{R}$ v.3.2.0 utilizando o pacote heatmap.2. Análise com distância euclidiana e usando o algorítimo UPGMA. O agrupamento do genes foi baseada na semelhança do padrão de expressão.....156 Figura 11. Clusterização e heat map da expressão de genes da biossíntese de fitoalexinas modulados segundo os diferentes tratamentos. A escala de cor indica o valor de expressão. O heat map foi gerado no programa R v.3.2.0 utilizando o pacote heatmap.2. Análise com distância euclidiana e usando o algorítimo UPGMA. O agrupamento do genes foi baseada na semelhança do padrão de expressão.

Figura 12. Clusterização e heat map da expressão de genes do citocromo P450 modulados segundo os diferentes tratamentos. A escala de cor indica o valor de expressão. O heat map foi gerado no programa R v.3.2.0 utilizando o pacote heatmap.2. Análise com distância euclidiana e usando o algorítimo UPGMA. O agrupamento do genes foi baseada na semelhança do padrão de expressão.....159

Figura 13. Clusterização e heat map da expressão de genes relacionados com resistência $(\mathrm{R})$ modulados segundo os diferentes tratamentos. A escala de cor indica o valor de expressão. O heat map foi gerado no programa $\mathrm{R}$ v.3.2.0 utilizando o pacote heatmap.2. Análise com distância euclidiana e usando o algorítimo UPGMA. O agrupamento do genes foi baseada na semelhança do padrão de expressão.

Figura 14. Clusterização e heat map da expressão de genes envolvidos na interação de hormônios de defesa e modulados segundo os diferentes 
Página

tratamentos. A escala de cor indica o valor de expressão. O heat map foi gerado no programa R v.3.2.0 utilizando o pacote heatmap.2. Análise com distância euclidiana e usando o algorítimo UPGMA. O agrupamento do genes foi baseada na semelhança do padrão de expressão.

Figura 15. Validação via qRT-PCR dos dados da expressão relativa do genes obtidos via RNA-seq. Níveis de expressão dos transcritos selecionados estão na barra preta (qRT-PCR) e na linha (RNA-seq). Dois genes, um de actina e outro de ubiquitia foram utilizados para normalização dos dados de qRT-PCR. As barras de erro indicam o desvio padrão para ensaios feitos com duplicata técnica. 


\section{RESUMO GERAL}

SPERANDIO, Eugenio Miranda. Resistência induzida por agentes bióticos e abióticos na interação Oryza sativa-Magnaporthe oryzae. 204p. Tese (Doutorado em Fitopatologia) - Universidade de Brasília, Brasília, DF.

O arroz (Oryza sativa L.) é uma das culturas mais importantes do mundo, sendo base para alimentação de metade da população global. O vigor inicial de cultivares de terras altas e a brusone (Magnaporthe oryzae) são os principais desafios enfrentados por essa cultura. O controle dessa doença é feito principalmente pelo uso de fungicidas e de cultivares resistentes. A alta variabilidade adaptativa do patógeno permite o aparecimento de indivíduos resistentes aos princípios ativos e o surgimento de novas raças capazes de suplantar os genes de resistência das cultivares de arroz. Isso torna necessário a constante busca por meios para contornar esses problemas visando conciliar o controle com preservação ambiental e saúde humana. Plantas possuem mecanismos de defesa que permanecem latentes e podem ser ativados. A indução de resistência (IR) possui potencial para ser aplicada no controle de doença de plantas. Os agentes indutores podem ser rizobactérias promotoras de crescimento e patógenos avirulentos, bem como hormônios vegetais. O objetivo deste trabalho foi verificar o efeito de Serratia sp. na promoção de crescimento e determinar e comparar a expressão gênica, aspectos bioquímicos e fenotípicos durante a ativação e interação de respostas de defesa em plantas de arroz desencadeadas por rizobactéria (Serratia sp.), M. oryzae avirulento (AVR) e Acibenzolar-S-metil (ASM) em resposta ao desafio com M. oryzae. Serratia sp BRM32114 promoveu o crescimento, reduziu o progresso da doença e induziu resistência, ativou respostas de defesa inicialmente regulados pelo ácido salicílico. A infecção não se estabeleceu em plantas tratadas com M. oryzae avirulento onde houve uma rápida ativação de $\beta$-1,3-glucanase (GLU) e peroxidase (POX), reação de hipersensibilidade (RH) e modificações histológicas nas plantas de arroz. Acibenzolar-S-metil (ASM), análogo do SA, induziu resistência sistêmica nas plantas com aparição de sintomas de RH e a aplicação de JA seguida do desafio com M. oryzae aumentou a suscetibilidade de arroz à brusone; o antagonismo entre JA e ASM foi confirmado pela inoculação do patógeno após a indução da planta com a aplicação em conjunto de ambos agentes indutores. A análise do transcritoma de plantas induzidas indicou que há semelhanças e algumas diferenças entre as respostas de defesa ativadas ISR e SAR, desencadeadas por Serratia sp. e M. oryzae AVR, respectivamente. Serratia sp. modula diferencialmente genes relacionados com biossíntese de SA e também 
alguns envolvidos no cross-talk entre os hormônios de defesa. M. oryzae avirulento superexpressa enzimas que degradam parede celular fúngica como GLU e quitinases, bem como enzimas envolvidas no estresse oxidativo. Já o isolado de $M$. oryzae virulento modula a seu favor genes que antagonisam respostas governadas por SA, superexpressando genes envolvidos na síntese de JA e aqueles envolvidos na degradação de espécies reativas de oxigênio.

Palavras-chaves: Imunidade das plantas, MAMP, patógeno-hospedeiro, priming de defesa, PTI, transcritoma.

Orientador - Prof. Dr. Helson Mário Martins do Vale - Universidade de Brasília, Brasília-DF; Co-orientador - Dra. Marta Cristina Corsi de Filippi - EMBRAPA Arroz e Feijão, Santo Antônio de Goiás-GO. 


\section{GENERAL ABSTRACT}

SPERANDIO, Eugenio Miranda. Resistance induced by biotic and abiotic agents in the interaction Oryza sativa-Magnaporthe oryzae. 204p. Thesis ( $\mathrm{PhD}$ in Phytopathology) University of Brasília, Brasília, DF.

Rice (Oryza sativa L.) is one of the most important crops in the world wide, being the basis for feeding half the global population. The initial vigor of upland cultivars and blast (Magnaporthe oryzae) are the main challenges faced by this crop. Today control of this disease is mainly achieved by the use of fungicides and resistant cultivars. The high adaptive variability of the pathogen allows the appearance of individuals resistant to the active principles and the emergence of new breeds capable of supplanting the resistance genes of the rice cultivars. This makes it necessary to constantly search for means to overcome these problems in order to reconcile control with environmental preservation and human health. Plants have defense mechanisms that remain latent and can be activated. Induced resistance (IR) has potential to be applied to plant disease control. The inducing agents may be plant growth-promoting rhizobacteria and avirulent pathogens, as well as plant hormones. The objective of this work was to verify the effect of Serratia sp. In the promotion of growth and to determine and compare gene expression, biochemical and phenotypic aspects during the activation and interaction of defense responses in rice plants triggered by rhizobacteria (Serratia sp.), M. oryzae avirulent (AVR) and Acibenzolar-S- Methyl (ASM) in response to challenge with $M$. oryzae. Serratia sp. BRM32114 promoted growth, reduced disease progression and induced resistance, activated defense responses initially regulated by salicylic acid. The infection was not established in plants treated with avirulent $M$. oryzae where there was a rapid activation of $\beta$-1,3-glucanase (GLU) and peroxidase (POX), hypersensitivity reaction $(\mathrm{RH})$ and histological modifications in rice plants. Acibenzolar-S-methyl (ASM), an analogue of SA, induced systemic resistance in plants with the appearance of HR symptoms and the application of JA followed by challenge with $M$. oryzae increased rice susceptibility to blast; The antagonism between JA and ASM was confirmed by inoculation of the pathogen after induction of the plant with the application together of both inducing agents. Induced plant transcriptase analysis indicated that there are similarities and some differences between the ISR and SAR activated defense responses, triggered by Serratia sp. and M. oryzae AVR, respectively. Serratia sp. Differentially modulates genes related to SA biosynthesis and also some involved in the cross-talk between defense hormones. $M$. oryzae avirulent overexpresses 
enzymes that degrade fungal cell wall like GLU and chitinases, as well as enzymes involved in oxidative stress. In contrast, the virulent $M$. oryzae isolate modulates genes that antagonize SA-governed responses, overexpressing genes involved in the synthesis of JA, and those involved in the degradation of reactive oxygen species.

Keywords: Defense priming, host-pathogen, MAMP, plant immunity, PTI, transcriptome.

Advisory Committee: Prof. Dr. Helson Mário Martins do Vale - Universidade de Brasília, Brasília-DF (Advisor); Dra. Marta Cristina Corsi de Filippi - EMBRAPA Rice and Beans, Santo Antônio de Goiás-GO (Co-advisor). 


\section{INTRODUÇÃO GERAL}

O Brasil é o nono maior produtor mundial de arroz e o maior produtor fora do continente asiático produzindo mais de 11 milhões de toneladas no último ano, valor correspondente a 1,6\% da produção mundial. Segundo a FAO, há uma necessidade de incremento na produção de $3 \%$ ao ano, entretanto, a projeção de crescimento é de apenas 38\% até 2030 (FAO, 2013). Sua produção é destinada ao consumo interno, que atinge $75 \mathrm{Kg} /$ habitante/ano e constitui-se no principal produto da cesta básica, correspondendo $22 \%$ do orçamento em alimentação (EMBRAPA, 2005). De acordo com IBGE (2013), no estado de Goiás a área destinada ao plantio do arroz para a safra 2012/2013 foi 48,9\% menor do que a safra 2011/2012, totalizando cerca de 29.790 ha a menos e estima-se uma redução na produção de 65,9\%, o que corresponde a $61.953 \mathrm{t}$ a menos. Entre os entraves para o aumento da produtividade destacam-se os estresses bióticos, como a incidência das doenças fúngicas, causada pelos patógenos Magnaporthe oryzae, Monographella albescens, Bipolaris oryzae, Rhizoctonia solani e Sarocladium oryzae, que podem diminuir em até $100 \%$ o potencial produtivo das cultivares geneticamente melhorada (Prabhu et al., 2002; Prabhu et al., 2009).

Atualmente, o controle das doenças vem sendo feito com o manejo que integra a resistência genética da cultivar e práticas fitotécnicas, incluindo controle o químico. A intensificação de cultivo de arroz, altamente mecanizado em áreas extensas e contínuas, proporciona um rápido desenvolvimento das doenças. Este cenário cria um desafio para adoção do manejo integrado de doenças, que, atualmente, requer a inserção de métodos alternativos, viáveis e apropriados, considerando aspecto sócio econômico, conservação de ambiente e a complexa biologia do patógeno $M$. oryzae. As investigações sobre controle biológico de brusone se faz necessário, considerando as demandas por tecnologias sustentáveis, como a redução de danos ambientais com o uso intensivo de produtos químicos. Dentro deste enfoque, a indução de resistência constitui-se em uma opção para fortalecer a adoção do manejo integrado (Prabhu et al., 2002; Filippi \& Prabhu, 2006; Filippi et al., 2011).

Para defenderem-se contra os patógenos, as plantas possuem mecanismos de defesa constitutivos e induzíveis (Verhagen et al., 2006). Mesmo quando suscetíveis, há mecanismos nas plantas que são capazes de retardar ou até mesmo impedir que uma infecção se estabeleça. Essas defesas estão diretamente reguladas ao nível de hormônios, tais como ácido jasmônico (JA), etileno (ET) e ácido salicílico (SA). A 
indução de resistência é classificada como induzida (ISR - "Induced Systemic Resistance") ou adquirida (SAR - "Systenic Acquired Resistance"). SAR e ISR são fenotipicamente semelhantes, embora sejam reguladas por diferentes vias de sinalização (Van der Ent et al., 2009). Ambas desencadeiam respostas de defesa como acúmulo de hormônios vegetais como ácido salicílico e ácido jasmônico, aumento de proteínas relacionadas à patogênese tais como $\beta$-1,3-glucanase, quitinase, peroxidase, reforço das paredes celulares pela deposição de lignina e ativação da expressão de genes de defesa. A SAR pode ser desencadeada por um agente patogênico ou pela aplicação de moléculas químicas anteriores ao momento da infecção, podendo apresentar reações de hipersensibilidade (RH). ISR é induzida por outros microrganismos não-fitopatogênicos como fungos e rizobactérias promotoras de crescimento de plantas, PGPF e PGPR, respectivamente (Raj et al., 2012; Zhu et al., 2013).

As respostas de resistência sistêmica, tanto SAR quanto ISR, são iniciadas a partir do momento em que os elicitores são reconhecidos (Van der Ent et al., 2009). Isso se dá principalmente por meio de componentes da superfície celular, como polissacarídeos (quitina e glucana) e flagelos. Os receptores das plantas responsáveis pelo reconhecimento desses elicitores se localizam principalmente na membrana plasmática (Faulkner \& Robatzek, 2012). Esses componentes microbianos são conhecidos como padrões moleculares associados a microrganismos (MAMPs) e/ou a patógenos (PAMPs) (Schwessinger \& Zipfel, 2008; Boller \& Felix, 2009; Pieterse et al., 2014).

No presente trabalho, os agentes elicitores Serratia sp. BRM32114, M. oryzae avirulento e virulento, previamente identificados, foram utilizados para estudos comparativos bioquímicos, genéticos e histológicos entre as rotas metabólicas envolvidos na indução de resistência em arroz contra M. oryzae. Além da compreensão mais ampla sobre indução de resistência em arroz, este trabalho poderá fornecer respostas aplicáveis para contornar os desafios do aumento produtividade de arroz de terras altas e controle de doença pelas rizobactérias bem como genes de defesa por meio da indução desencadeada por isolados de M. oryzae avirulentos. 


\section{OBJETIVO GERAL}

Determinar e comparar a expressão gênica e aspectos fenotípicos durante a indução de SAR e ISR em plantas de arroz desafiadas com Magnaporthe oryzae.

\section{Objetivos Específicos}

1) Avaliar variáveis de promoção de crescimento (atividade de nitrato redutase e tamanho e peso de plantas) induzidas com rizobactérias Bacillus sp. (BRM32110) e Serratia sp. (BRM32114).

2) Quantificar as enzimas quitinase, $\beta$-1,3-glucanase, peroxidase, fenilalanina amônialiase, lipoxigenase, quantificar compostos fenólicos e ácido salicílico durante a defesa da planta induzida com Serratia sp. BRM32114 e M. oryzae avirulento contra brusone do arroz.

3) Verificar modificações estruturais por microscopia de luz in situ em folhas de arroz induzidas com M. oryzae avirulento.

4) Verificar o antagonismo entre as respostas de defesa desencadeadas por ASM e JA, como os mecanismos de defesa interagem e seus efeitos no controle de M. oryzae.

5) Comparar o perfil dos transcriptomas de plantas de arroz induzidas com Serratia sp., M. oryzae avirulento e $M$. oryzae virulento observando os genes diferencialmente expressos em cada um desses tratamentos. 


\section{REVISÃO DE LITERATURA}

\section{A cultura do arroz}

O arroz (Oryza sativa) é a fonte de $20 \%$ de calorias e $13 \%$ das proteínas consumidas no mundo para cerca de três bilhões de pessoas da população mundial, sendo a base da alimentação de metade da população mundial, sendo, portanto, uma cultura com grande importância na manutenção da segurança alimentar a nível mundial (FAO, 2013). O consumo do arroz cereal tende a aumentar à medida que a população cresce, porém a sua produção não sobe na mesma proporção e em alguns locais decresce, principalmente devido à redução da área plantada e a queda na produtividade. Uma das causas é a ocorrência de doenças. Há estimativas de que a produção deve ser dobrada até 2050 para atender a demanda populacional por este alimento (Khush, 2005).

A cadeia orizícola de produção movimenta anualmente cerca de $\mathrm{R} \$ 4$ bilhões ao ano no Brasil, representando $11 \%$ do total da produção agrícola brasileira. A produtividade média do arroz no país é aproximadamente 7 ton/ha (IBGE, 2012) e espera-se um crescimento de 7,2\% da produção nos próximos dez anos (MAPA, 2015). O cultivo do arroz no Brasil é feito sob dois sistemas: arroz irrigado e arroz de terras altas. O primeiro é cultivado principalmente nos estados do Rio Grande do Sul, Santa Catarina, Mato Grosso, Maranhão e Tocantins, sendo o irrigado o sistema com a maior produção e produtividade; o segundo é cultivado majoritariamente na região centronorte (CONAB, 2015). O sistema de produção de arroz de terras altas vem aumentando sua porcentagem na produção orizícola nacional, espalhando e aumentando sua área de cultivo no centro-oeste, norte e nordeste do Brasil (Crusciol et al., 2005). Menores custos de produção, gasto de eletricidade e consumo de água são algumas vantagens que este sistema possui sobre o cultivo irrigado, porém, o arroz de terras altas possui uma baixa resposta a adubação. Isso é devido a problemas de desenvolvimento inicial e crescimento da planta, principalmente em áreas de cultivos sucessivos, além da alta ocorrência de doenças, resultando numa baixa produtividade quando comparado ao arroz irrigado (Filippi et al., 2012).

\section{Brusone}

Entre as doenças do arroz, a brusone, cujo agente etiológico é o fungo Magnaporthe oryzae, é um dos principais fatores limitantes dessa cultura. Essa doença é comum a todas as regiões produtoras do mundo, e em anos de epidemias severas, as perdas podem chegar a 100\%. A brusone ocorre em todos os estádios fenológicos da 
planta de arroz. Os sintomas nas folhas iniciam-se com o aparecimento de lesões necróticas elípticas, geralmente com o centro cinza, onde ocorre a esporulação do fungo, e borda marrom, podendo coalescer à medida que crescem, levando à morte as folhas infectadas. Os sintomas são encontrados também em outras partes das plantas, como os nós, entrenós e panículas, potencializando as perdas (Prabhu et al., 2002; 2009).

M. oryzae é um patógeno hemibiotrófico pertencente ao Filo Ascomycota. Tem como anamorfo o hifomiceto moniliáceo Pyricularia oryzae. Suas hospedeiras são majoritariamente da família Poaceae. M. oryzae é utilizado como organismo modelo para investigação de interação planta-fungo. Isso ocorre devido à sua importância econômica, pelo fato de seu genoma bem como do arroz terem sido sequenciados e pelas características biológicas do próprio patógeno (Richard et al., 2009). O fungo pode atacar a planta de arroz em todos os seus estágios de desenvolvimento, podendo infectar folhas, caules, nós e panículas. O conídio do fungo se adere a superfície da planta por meio de uma mucilagem no ápice do conídio, prendendo-o na hospedeira e emitindo um tubo germinativo. Esse tubo dilata-se na ponta, forma uma parede celular mais espessa e então diferencia-se num apressório. O apressório começa a acumular melanina, cria a pressão de turgor, aumenta a pressão sob a superfície foliar, e emite uma hifa de penetração (peg), que perfura a cutícula permitindo a entrada do fungo na epiderme foliar. A colonização inicia-se com as hifas invasivas que produzem haustórios que invaginam na membrana plasmática das células da hospedeira. $\mathrm{O}$ movimento célula-à-célula. pode iniciar-se por meio dos plasmodesmos. As lesões tornam-se visíveis entre 72 e 96 horas após a penetração e a esporulação ocorre principalmente em condições altas de umidade. O seu desenvolvimento na planta iniciase por meio de uma colonização intercelular, com a formação de haustórios nas células das hospedeiras. Com a morte das células colonizadas, o fungo passa a nutrir-se de células mortas, iniciando-se a fase necrotrófica da colonização (Wilson \& Talbot, 2009; Dean et al., 2012).

Atualmente, o controle da brusone é baseado no manejo que integra o controle químico, a resistência genética e os tratos culturais. No Brasil, 41 produtos estão registrados no Ministério da Agricultura e Pecuária e Abastecimento (MAPA). Os principais grupos químicos são os triazol, estrobirulina e benzotiazol (AGROFIT, 2016). O uso de defensivos requer uma aplicação constante e o melhoramento genético necessita da disponibilidade de genes e ambos os métodos de controle são limitados a 
um ou poucos patógenos. A resistência genética visa minimizar as perdas causadas pela brusone. É uma estratégia considerada social, econômica e ecologicamente correta e ao longo dos anos tem-se obtido cultivares resistentes por meio de técnicas de melhoramento convencional. Entretanto, cultivares de arroz geneticamente melhoradas para resistência a brusone, não apresentam resistência estável, quando plantada em larga escala, causando descrécimos na produtividade (Ou et al., 1980). A duração da resistência de um determinado cultivar dependerá da velocidade e facilidade que o fitopatógeno seja capaz de produzir novos patótipos (Parleviet \& Zadoks, 1977), o que acontece de forma muito rápida quando se trata de $M$. oryzae, quando comparados com outros patógenos. O seu teleomorfo encontrado na natureza somente no centro de origem do arroz no sudeste da Ásia, porém, mutações e recombinações gênicas parassexuais são os principais eventos responsáveis pela alta variabilidade deste fitopatógeno (Dean et al., 2012).

Mais de 90 genes de resistência (R) para $M$. oryzae já foram identificados (Monaco et al., 2013), entretanto, embora esforços tenham sido feito para o desenvolvimento constante de novas cultivares resistentes, utilizando vários alelos de resistência como fonte para o melhoramento, o desafio do controle ainda permanece. Os conhecimentos sobre a interação patógeno-hospedeiro constituem-se num recurso eficiente nos estudo do processo infeccioso ajudando a esclarecer os acontecimentos do ciclo patogênico, antes, durante e após o estabelecimento da infecção, elucidando os eventos morfológicos e fisiológicos da patogênese. Isso possibilita um aumento na eficiência dos métodos de controle (Richard et al., 2009). A genômica permitiu obter-se um conhecimento mais amplo em relação aos genes envolvidos na resistência a brusone. Esta ferramenta possibilita explorar mais detalhadamente a complexidade dos mecanismos de defesa da planta, gerando perspectivas de novas estratégias de manejo (Monaco et al., 2013).

Neste contexto, a indução de resistência, que é a ativação de mecanismos de defesa da própria planta, surge como uma alternativa no controle desta doença, entretanto, para fazer uso dessa ferramenta, é necessário que se conheça os mecanismos envolvidos na interação entre patógeno e hospedeira (Van der Ent et al., 2009). Do ponto de vista ambiental, induzir a defesa de plantas é uma forma mais atrativa e inteligente quando comparada com controle químico, deixando que o hospedeiro se proteja através de seus próprios mecanismos contra uma ampla gama de fitopatógenos, de forma duradoura. O uso de defensivos ainda é, contudo, uma alternativa usada no 
controle da brusone (Schwan-Estrada et al., 2008; Raj et al., 2012). É provável que a resistência induzida contra doenças através de ativadores químicos ou por outros meios se torne um componente importante dos programas de manejo de doenças, particularmente nos casos onde os métodos atuais de controle mostram-se pouco efetivos, bem como no controle de doenças de pós-colheita envolvendo sementes, grãos, frutas e vegetais. Obviamente, um dos resultados dessa nova tecnologia deverá ser a diminuição no uso dos agrotóxicos tradicionais, o que vem de encontro com a preocupação mundial no tocante à preservação do meio ambiente e a redução da poluição, tornando-se uma importante ferramenta para uma agricultura sustentável (Van der Ent et al., 2009; Walters et al., 2013).

\section{Indução de resistência}

Plantas possuem mecanismos eficientes de defesa que permanecem latentes e são ativados por agentes indutores, tais mecanismos são conhecidos como pósformados. A deposição de materiais que reforçam as barreiras físicas celulares como lignina e calose, o acúmulo de fitoalexinas e aumento da produção de proteínas relacionadas a patogênese são considerados mecanismos pós-formados de defesa. Mesmo quando suscetíveis, esses mecanismos são capazes de retardar ou até mesmo impedir que a infecção se estabeleça. Compostos antimicrobianos desempenham um papel importante nos mecanismos de defesa da planta. Indução de defesa envolve a ativação de mecanismos múltiplos que incluem o aumento da atividade de proteínas relacionada à patogênese (PRP) e um aumento no nível de hormônios de defesa como ácido salicílico (SA) e ácido jasmônico (JA). O aumento do nível de tais hormônios é frequentemente relacionado com um ataque por patógenos. Esses aumentos dependem do fitopatógeno, visto que cada hormônio age na resistência contra uma dada gama patógenos e os papéis de diferentes hormônios variam de acordo com a interação plantapatógeno (Verhagen et al., 2006; Mengiste, 2012; Walters et al., 2013; Pieterse et al., 2014).

Quando atacadas, plantas são capazes de aumentar sua resistência e essa condição é referida como resistência adquirida ou induzida (Verhagen et al., 2006). A indução de resistência em plantas é organizada em dois tipos: resistência sistêmica adquirida (SAR) e resistência sistêmica induzida (ISR) (Figura 1). SAR pode ser desencadeada após uma infecção local ou em diferentes pontos, estendendo-se para partes da planta distante do local de infecção, podendo ser induzida por patógenos e por 
moléculas químicas (Zhu et al., 2003; Vlot et al., 2009; Walters et al., 2013). A indução da SAR é acompanhada pela produção e acúmulo local e/ou sistêmico do ácido salicílico (SA) e que ativam genes relacionados à patogênese (PR-genes) que por sua vez, se expressam através da síntese de proteínas relacionadas à patogênese (PRP) (Van Loon \& Van Strien, 1999; Vlot et al., 2009). Plantas possuem um mecanismo rápido e efetivo contra patógenos biotróficos, que previne a disseminação da infecção causada por fitopatógenos; este mecanismo é conhecido como reação de hipersensibilidade (HR). A HR é um processo que culmina numa morte rápida e programada das células que circundam os sítios de infecção, restringe a colonização pelo patógeno dos tecidos sítio de infecção e vizinhas a ele e impede o estabelecimento da doença. Esta reação se dá por meio da expressão de genes de defesa, produção de moléculas antimicrobianas, síntese de lignina e principalmente pela explosão oxidativa, que é a produção de espécies reativas de oxigênio (ROS) (Camejo et al., 2016), sendo este mecanismo, que pode ser observado em plantas induzidas, um indicador clássico de indução de resistência (Kunstler et al., 2016).

Microrganismos benéficos do solo podem induzir uma imunidade sistêmica similar a SAR. Este fenômeno é chamado de indução de resistência sistêmica (ISR). Em contraste com SAR, ISR pode ser ativado por microrganismos não-fitopatogênicos como rizobactérias promotoras de crescimento de plantas (PGPR) (Raj et al., 2012) e fungos (PGPF) (Campos-Soriano et al., 2012) e é regulada por vias de sinalização dependentes de jasmonatos e etileno (Pieterse el al., 2014). Lipopolissacarídeos são exemplos de elicitores de PGPRs que podem desencadear respostas de defesa em plantas. Xilanases, celulases e outras proteínas enzimáticas, bem como o pepitídeo Sm1 produzido por Trichoderma virens são exemplos de elicitores produzidos por PGPF (Pieterse et al., 2014). Estes microrganismos induzem a resistência e protege não só as raízes como também órgãos distantes por ela colonizados e podem exibir mecanismos antagônicos contra fitopatógenos, como competição por nicho e nutrientes, além de promover o crescimento (Babalola, 2010; Matilla et al., 2010). A promoção de crescimento pode ser atribuído a produção de hormônios de crescimento bem como um aumento da disponibilidade de nutrientes limitados no solo como $\mathrm{P}, \mathrm{Fe}$ e N, com o metabolismo do $\mathrm{N}$ possuindo papel de destaque no crescimento e em infecções (Bolton \& Thomma, 2008). Além da resistência basal que age nos sítios de infecção, as hospedeiras aumentam níveis de hormônios sinalizadores e aumentam também a expressão de genes de defesa em locais distantes dos sítios de infecção. Fortificação e 
espessamento da parede celular, formação de papilas, produção de compostos fenólicos e de espécies reativas de oxigênio (EROs) são algumas das mudanças observadas em plantas que estão no estado de ISR (Raj et al., 2012), onde hormônios vegetais como ácido jasmônico (JA), etileno (ET) e ácido abscísico estão envolvidos (Pieterse et al., 1998; Mengiste, 2012; Pieterse et al., 2014).

Apesar de SAR e ISR serem fenotipicamente semelhantes, conferindo às plantas uma proteção sistêmica contra uma gama de patógenos, elas são reguladas por diferentes tipos de vias de sinalização. Embora SAR e ISR forneçam às plantas uma proteção contra diferentes tipos de patógenos, o seu alcance pode ser diferente dependendo do tipo de colonização do patógeno (Van der Ent et al., 2009). Sinalização feita por SA ativa resistência contra patógenos biotróficos e hemibiotróficos. Já a combinação JA-ET ativa a defesa contra patógenos com estilo de nutrição necrotrófico (Glasebook, 2005). Essas vias de sinalização são antagônicas. Resistência contra patógenos biotróficos/hemibiotróficos são frequentemente relacionados com um aumento na suscetibilidade a patógenos necrotróficos e níveis elevados de resistência a patógenos necrotróficos estão associados com uma maior suscetibilidade das hospedeiras ao ataque de patógenos biotróficos e/ou hemibiotróficos (Van der Ert et al., 2008; Segarra et al., 2009; Shetty et al., 2012). A contribuição desses hormônios na relação patógeno-hospedeiro é crucial para uma possível patogênese (Robert-Seilaniantz et al., 2011).

A maioria dos estudos de indução com microrganismos benéficos são associados com JA/ET (Van Lon \& Bakker, 2006), entretanto, vários trabalhos apontam o envolvimento de não-fitopatógenos induzindo resistência utilizando SA como via de sinalização (Conn et al., 2008; Rudrappa et al., 2008; Pieterse et al., 2014). Sabe-se que o ácido salicílico está associado à SAR, entretanto, há evidências que há outros hormônios envolvidos nesta via de sinalização. Verbene et al. (2003) demonstraram que para o começo da SAR em tabaco, o etileno é requerido para desencadear o processo de indução via SA contra infecção por Tobbaco Mosaic Virus. Trabalhos feito por Truman et al. (2007) mostraram que mutantes de Arabidopsis thaliana nos genes (sgt1b, opr3 e jinl) envolvidos na via de sinalização de jasmonatos foram incapazes de manifestar SAR quando inoculadas com Pseudomonas syringae pv. tomato avirulentas. Por outro lado, mutantes dos genes jarl, eds8 e coil, todos envolvidos com a síntese de JA, submetidos ao mesmo tratamento, foram capazes de desencadear SAR (Pieterse et al., 
1998; Attaran et al., 2009). Isso sugere que JA está envolvido no desenvolvimento de SAR, mas seu papel exato em SAR ainda não foi elucidado (Van der Ent et al., 2009).

A proteína NPR1 (Nonexpressor of Pathogenesis-Related Genes1) é citada como crucial na indução de resistência, tendo um papel chave nas respostas de SAR (Delaney et al., 1995; Jiang et al., 2009; Sugano et al., 2010) e ISR (Pieterse et al., 2000; Mengiste, 2012) (Figura 1). Plantas demonstraram ser mais suscetíveis ao ataque de patógenos quando a expressão do gene NPRl (também conhecido como NIM1 ou SAI1) se mostrava reprimida (Delaney et al., 1995). Por outro lado, a superexpressão do NPR1 ou de genes análogos aumentou a resistência ao ataque de patógenos (Sugano et al., 2010). A ativação da NPR1 ocorre através da redução de uma forma oligomérica citoplasmática em uma forma monomérica. A forma monomérica é então transferida para o núcleo para a ativação dos PR-genes (Mou et al., 2003). Estudos revelaram que essa proteína regulatória desempenha papéis diferentes na regulação da indução de resistência mediada por SA ou JA/ET (Leon-Reyes et al., 2009). Mutantes do gene nprl em Arabidopsis foram incapazes de ativar a ISR quando inoculadas com a PGPR Pseudomonas putida LSW17S (Ahn et al., 2007). A expressão de PR-genes dependentes de SA é atribuído ao gene NPRl que regula positivamente a SAR (Sugano et al., 2010) entretanto, na ISR os genes PR ativados não são os mesmos que são diferencialmente expressos na SAR (Mengiste, 2012; Pieterse et al., 2014). 
$\downarrow$

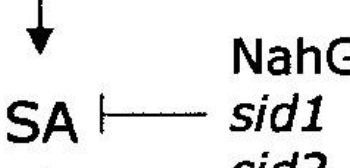

$\operatorname{sid} 2$

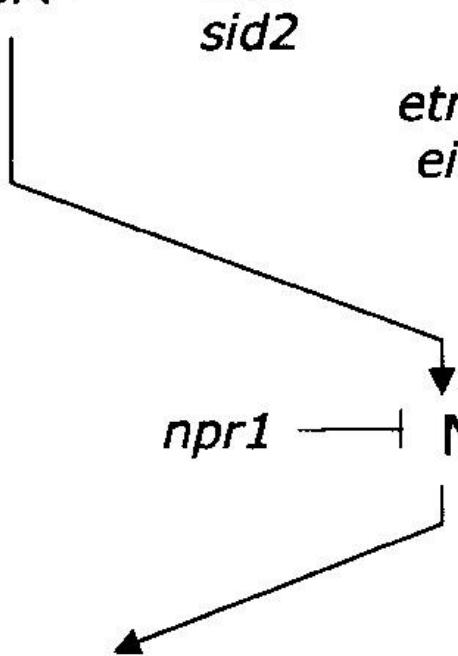

PRs

\section{SAR}

1

jar1 $\longrightarrow$ Resposta JA

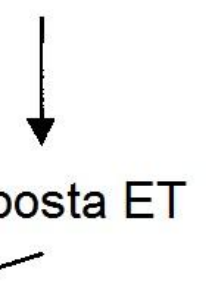

ein 1-ein $\longrightarrow$ Resposta ET

isr 1

eds8

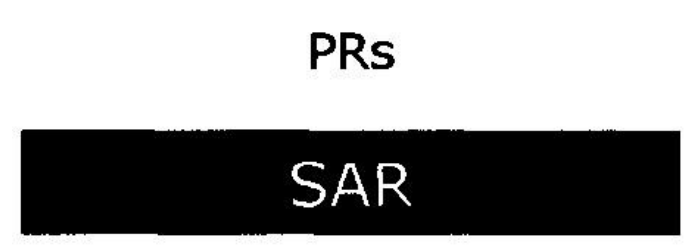

Priming para aumentar a expressão de genes de defesa

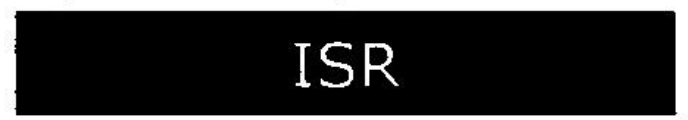

Pieterse et al., 2002.

Figura 1. Vias de transdução de sinais relacionados com SAR e ISR.

O genoma do arroz possui mais de 100 genes WRKY, genes envolvidos na regulação de genes associados à resistência do arroz a M. oryzae e/ou Xanthomonas oryzae pv. oryzae, genes estes ativados via SA e regulados por NPR1 (Berry et al., 2009; Abbruscato et al., 2012) e também estão envolvidos no equilíbrio entre as respostas de defesa dependentes de JA e SA. A aplicação de Glomus intraradices, um fungo formador de micorriza arbuscular em plantas de arroz, ativaram sistemicamente os genes OsNPR1, dependente de SA, e OsJAmyb e OsMPK7, estes últimos dependentes de JA (Campos-Soriano et al., 2012). O gene NPR1 quando ativado via SA, inibe as respostas gênicas desencadeadas via MeJA (metil-jasmonato), interferindo nos octadecanóides, moléculas envolvidas em ISR via JA (Mao et al., 2007). Trabalhos mostram que (ET) media o efeito-cruzado entre MeJA-AS, através de uma interação com NPR1 de uma maneira que varia dependendo da sua concentração (Leon-Reyes et al., 2009). O aumento do ET causado por herbivoria tem sido observado com uma produção simultânea de JA resultando numa elicitação de genes ativados por JA (Diezel 
et al., 2009). O contrário disso tem sido proposto: quando patógenos ou herbívoros não induzem um aumento de ET, o ácido salicílico atua inibindo a expressão de genes ativados por JA por mecanismos independentes de NPR1. Mecanismos dependentes ou não de NPR1 que atuam suprimindo as expressões de genes mediados por JA, podem deixar a planta numa condição de suscetibilidade em relação à herbivoria e ao ataque de patógenos necrotróficos (Leon-Reyes et al., 2009). NPR1 são também reguladores, em várias espécies de plantas, dos fatores de transcrição WRKY que estão envolvidos na ativação de SAR via SA. Plantas de arroz geneticamente modificadas que superexpressaram WRKY45 foram resistentes a $X$. oryzae pv. oryzae e a $M$. oryzae, patógenos biotróficos e hemibiotróficos respectivamente, entretanto, essas mesmas plantas se mostraram suscetíveis quando inoculadas com o patógeno necrotrófico Rhizoctonia solani (Shimono et al., 2012).

Todo mecanismo de resistência que a planta emprega contra um determinado patógeno ou estresse abiótico, é controlado pelo material genético tanto da planta hospedeira quanto do patógeno. O reconhecimento é realizado por produtos dos genes de resistência da planta. A resposta de resistência sistêmica é iniciada quando ocorre o reconhecimento dos indutores químicos e/ou dos microrganismos, patogênicos ou não (Van der Ent et al., 2009). Estes microrganismos são reconhecidos pela planta, majoritariamente, através de componentes da superfície microbiana de suas células, tais como $\beta$-1,3-glucana, flagelinas (proteína constituinte de flagelos) e Lipopolissacarídeos (LPS). As plantas possuem receptores de reconhecimento de padrões (PRRs) desses sinais na sua membrana plasmática que reconhecem essas estruturas microbianas (Faulkner \& Robatzek, 2012). Coletivamente, estes componentes reconhecidos pelas plantas são chamados de padrões moleculares associados a patógenos (PAMPs) e a microrganismos (MAMPs) (Schwessinger \& Zipfel, 2008; Kishi-Kaboshi et al., 2010; Yang et al., 2015). Quitina (Miya et al., 2007), peptideoglicano (Wilmann et al., 2011) e fatores de elongação bacterianos (Zipfel et al., 2006) são os padrões moleculares. Os padrões moleculares associados a danos (DAMPs), como peptídeos de plantas ou fragmentos da parede celular produzidos durante ataques de patógenos, são fatores também reconhecidos pelos PRRs (Monaghan \& Zipfel, 2012). PAMP são reconhecidas por PRRs em plantas, que por sua vez, engatilham mudanças fisiológicas nas plantas em resposta a este estímulo, resultando numa imunidade ativada por PAMP (PTI - PAMPtriggered immunity). São exemplos de uma resposta PTI o aumento no nível de cálcio e de EROs, bem como a ativação de quinases dependentes de cálcio e proteínas ativadas 
por mitógeno (CDPKs e MAPKs, respectivamente), levando a uma reprogramação massiva na transcrição de genes (Boller \& Felix, 2009). Essa interação molecular não raro ocorre de uma maneira específica entre cultivar da planta e estirpe do patógeno e é descrita como fator de avirulência (avr) do patógeno que por sua vez é reconhecido por genes de resistência das hospedeiras. A supressão da PTI juntamente com a produção de efetores do patógeno ativa outros mecanismos de defesa da planta. Este fenômeno é conhecido por imunidade ativada por efetores (ETI) (Figura 2). Quando há este reconhecimento, um processo de HR pode ser iniciado (Coll et al., 2010). Vários MAMPs produzidos por microrganismos benéficos como PGPRs têm sido identificados, estando envolvidos no começo de ISR. Quando este estado de indução das plantas é desencadeado por microrganismos, ele recebe o nome de imunidade ativada por MAMP (MTI) (Bakker et al., 2007; Kishi-Kaboshi et al., 2010; Pieterse et al., 2014).
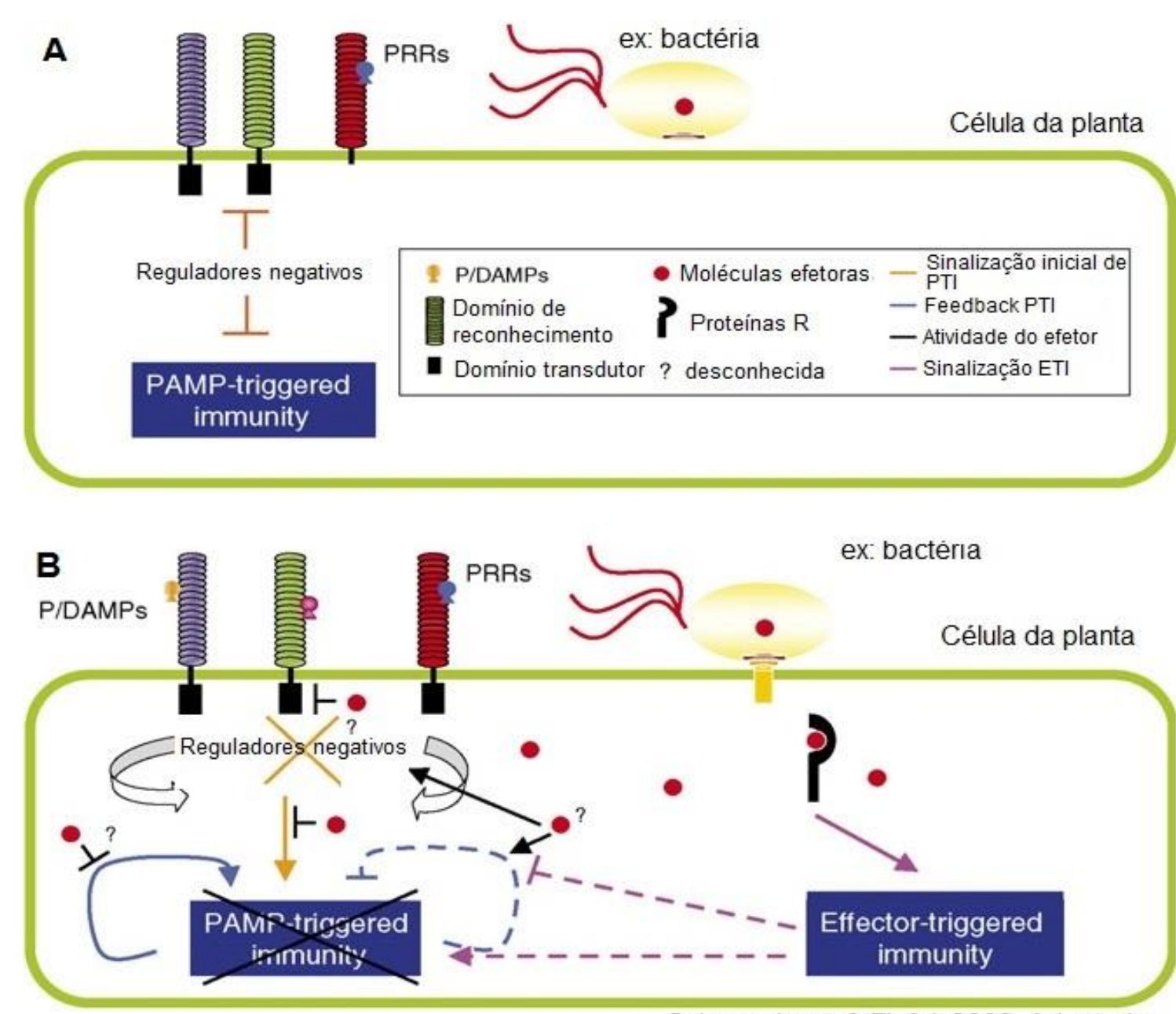

Schwessinger \& Zipfel, 2008. Adaptado

Figura 2. Esquema da ativação da defesa por patógenos - PTI (A) e por efetores - ETI (B). 
Trabalhos utilizando mutantes com os sinais de transdução e resposta de defesa defeituosa tem fornecido dados relacionados com a regulação da resistência de várias plantas a diferentes patógenos (Berrocal-Lobo \& Molina, 2008). Assim como em outros patossistemas, sabe-se pouco sobre a dinâmica do transcriptoma de defesa da planta de arroz quando induzida. Nos anos 90 e início do século XXI, utilizava-se a tecnologia de microarray para análise de expressão gênica via hibridização, identificando simultaneamente vários transcritos e genes diferencialmente expressos, entretanto, é necessário um conhecimento prévio destes genes (Zhu et al., 2013). A tecnologia de Next-Generation Sequencing (NGS) fornece uma estratégia eficiente para análise de transcriptomas. O sequenciamento do RNA é uma ferramenta de sequenciamento em larga escala para análises de transcriptomas e, diferente do método de microarray que hibridiza os transcritos de interesse, sequencia diretamente os transcritos presentes no material em estudo, sendo essa tecnologia bastante sensível e pode detectar transcritos pouco expressos. Solexa-Illumina ${ }^{\circledR}$ e SOLiD-Applied Biosystems são exemplos de plataformas utilizadas em estudos com a tecnologia NGS. A escolha da plataforma NGS depende, por exemplo, da natureza do experimento e do tamanho das sequencias a serem sequenciadas (Zhu et al., 2013b; Zhu et al., 2013).

É necessário um melhor conhecimento do papel que os hormônios de defesa SA, JA e ET e outros componentes das vias de defesa desempenham no patossistema $O$. sativa-M. oryzae entendendo o envolvimento destas vias de sinalização a fim de melhor explorar a indução de resistência, aplicando estes conhecimentos em condições de cultivo no campo para o controle sustentável da brusone do arroz. 


\section{REFERÊNCIAS BIBLIOGRÁFICAS}

ABBRUSCATO, P.; NEPUSZ, T.; MIZZI, L.; DEL CORVO, M.; MORANDINI, P.; FUMASONI, I.; MICHEL, C.; PACCANARO, A.; GUIDERDONI, E.; SCHAFFRATH, U.; MOREL, JB.; PIFFANELLI, P. \& FAIVRE-RAMPANT, O. 2012. OsWRKY22, a monocot WRKY gene, plays a role in the resistance response to blast. Molecular Plant Pathology 13:828-841.

AGROFIT

2016.

Disponível

em:

http://agrofit.agricultura.gov.br/agrofit_cons/principal_agrofit_cons. Acesso em 11 de dez. de 2016.

ATTARAN, E.; ZEIER, T.E.; GRIEBEL, T. \& ZEIER, J. 2009. Systemic acquired resistance in Arabidopsis is independent of methyl salicylate production and jasmonate signaling. Plant Cell, 21: 954-971.

BABALOLA, O.O. 2010. Beneficial bacteria of agricultural importance. Biotechnological Letters, 32: 1559-1570.

BAKKER, P.A.H.M.; PIETERSE, C.M.J. \& LOON, L.C.V. 2007. Induced systemic resistance by fluorescent Pseudomonas spp. Phytopathology, 97:239-243

BERRI, S.; ABBRUSCATO, P.; FAIVRE-RAMPANT, O.; BRASILEIRO, A.C.M.; FUMASONI, I.; SATOH, K.; KIKUCHI, S.; MIZZI, L.; MORANDINI, P.; PÈ, M.E. \& PIFFANELLI, P. 2009. Characterization of WRKY co-regulatory networks in rice and Arabidopsis. BMC Plant Biology 9:120.

BERROCAL-LOBO, M. \& MOLINA, A. 2008. Arabidopsis defense response against Fusarium oxysporum. Trends in Plant Science, 13:145-150.

BOLLER, T. \& FELIX, G. 2009. A renaissance of elicitors: perception of microbeassociated molecular patterns and danger signals by pattern-recognition receptors. Annual Review of Plant Biology, 60:379-406. 
BOLTON, M.D.; THOMMA, B.P.H.J. 2008. The complexity of nitrogen metabolism and nitrogen-regulated gene expression in plant pathogenic fungi. Physiological and Molecular Plant Pathology, 72: 104-110.

CAMEJO, D.; GUZMÁN-CEDEÑO, A. \& MORENO, A. 2016. Reactive oxygen species, essential molecules, during plant-pathogen interactions. Plant Physiology and Biochemistry 103:10-23.

CAMPOS-SORIANO, L.C.; GARCIA-MARTINEZ, J. \& SEGUNDO, B.S. 2012. The arbuscular mycorrhizal symbiosis promotes the systemic induction of regulatory defence-related genes in rice leaves and confers resistance to pathogen infection. Molecular Plant Pathology, 13: 579-592.

COLL, N.S.; VERCAMMEN, D.; SMIDLER, A.; CLOVER, C.; VAN BREUSEGEM, F.; DANGL, J.L. \& EPPLE, P. 2010. Arabidopsis type I metacaspases control cell death. Science, 330: 1393-1397.

CONAB 2015. $2^{\circ}$ Levantamento de grãos-Safra 2015/16. Disponível em: http://www.conab.gov.br/OlalaCMS/uploads/arquivos/15_11_16_15_18_26_safr as_nov_2015.pdf. Acesso em: 03 de dezembro de 2015.

CRUSCIOL, C.A.C.; MAUAD, M.; ALVAREZ, R.C.F.; LIMA, E.V. \& TIRITAN, C.S. 2005. Doses de fósforo e crescimento radicular de cultivares de arroz de terras altas. Bragantia, 64: 643-649.

DEAN, R.; VAN KAN, JAL.; PRETORIUS, Z.A.;, HAMMOND-KOSACK, K.E.; DI PIETRO, A.; SPANU, P.D.; RUDD, J.J.; DICKMAN, M; KAHMANN, R.; ELLIS, J. FOSTER, G.D. 2012. The Top 10 fungal pathogens in molecular plant pathology. Molecular Plant Pathology, 13: 414-430.

DELANEY, T.P.; FRIEDRICH, L. \& RYALS, J.A. 1995. Arabidopsis signal transduction mutant defective in chemically and biologically induced disease resistance. Proceedings of the National Academy of Science USA 92:66026606. 
EMBRAPA-Empresa Brasileira de Pesquisa Agropecuária - Embrapa Clima Temperado Sistemas de Produção, 3 ISSN 1806-9207 Versão Eletrônica Nov./2005. Disponível

em: <http://sistemasdeproducao.cnptia.embrapa.br/FontesHTML/Arroz/ArrozIrrigad oBrasil/cap11_01>. Acesso em: 07 set. 2013.

FAO 2013. FAOSTAT. Disponível em: http://faostat3.fao.org/faostatgateway/go/to/download/Q/QC/E. Acesso em: 07 de set. de 2013.

FAULKNER, C. \& ROBATZEK, S. 2012. Plants and Pathogens: putting infectio:n strategies and defence mechanisms on the map. Current Opinion in Plant Biology, 15: 699-707.

FILIPPI, M.C. \& PRABHU, A.S. 2006. Brusone em arroz: controle genético, progresso e perspectivas. Embrapa. Embrapa Arroz e Feijão (CNPAF), Santo Antônio de Goiás.

FILIPPI, M.C.C., SILVA, G.B., SILVA-LOBO, V.L., CÔRTES, M.V.C.B., MORAES, A.J.G., PRABHU, A.S., 2011. Leaf blast (Magnaporthe oryzae) suppression and growth promotion by rhizobacteria on aerobic rice in Brazil. Biological Control, 58:160-166.

FILIPPI, M.C.C.; SILVA, G.B.; CORTES, M.V.B.; SILVA-LOBO, V.L. \& PRABHU, AS. 2012. Indução de resistência e promoção de crescimento em arroz por agentes biológicos. In: RODRIGUES, F.A.; FORTUNATO, A.A. \& RESENDE, R.S. (Ed.). Indução de resistência a patógenos: VI Reunião Brasileira Sobre Indução de Resistência em Plantas a Patógenos na Universidade Federal de Viçosa. Suprema Gráfica e Editora Ltda. Viçosa. p.51-78.

GLAZEBROOK, J. 2005. Contrasting mechanisms of defense against biotrophic and necrotrophic pathogens. Annual Review of Phytopathology, 43:205-27

IBGE, 2012. Anual Estatístico do Brasil. 
MAPA, 2015. Ministério da Agricultura, Pecuária e Abastecimento. Projeções do agronegócio.

KHUSH, G.S. 2005. What it will take to feed 5.0 billion rice consumers in 2030. Plant Molecular Biology 59:1-6.

KISHI-KABOSHI， M.; OKADA， K.; KURIMOTO， L.; MURAKAMI， S.; UMEZAWA, T.; SHIBUYA, N.; YAMANE, H.; MIYAO, A.; TAKATSUJI, H.; TAKAHASHI, A. \& HIROCHIKA, H. 2010. A rice fungal MAMP-responsive MAPK cascade regulates metabolic flow to antimicrobial metabolite synthesis. The Plant Journal 63:599-612.

KUNSTLER, A.; BACSO, R.; GULLNER, G.; HAFEZ, Y.M. \& KIRALY, L. 2016. Staying alive - is cell death dispensable for plant disease resistance during the hypersensitive response? Physiological and Molecular Plant Pathology 93:75-84.

LEON-REYES, A.; SPOEL, S.H., DE LANGE, E.S;. ABE, H.; KOBAYASHI, M.; TSUDA， S.; MILLENAAR，F.F.; WELSCHEN， R.A.; RITSEMA，T. \& PIETERSE, C.M. 2009. Ethylene modulates the role of Nonexpressor of Pathogenesis-Related genes1 in cross talk between salicylate and jasmonate signaling. Plant Physiology. 149: 1797-1809.

MATILLA, M.A.; RAMOS, J.L.; BAKKER, P.A.H.M.; DOORNBOS, R.; BADRI, D.V.; VIVANCO, J.M. \& RAMOS-GONZALES, M.I. 2010. Pseudomonas putida KT2440 causes induced systemic resistance and changes in Arabidopsis root exudation. Environmental Microbiology Reports. 2: 381-388.

MENGISTE, T. 2012. Plant Immunity to necrotrophs. Annual Reviews of Phytopathology 50:267-294.

MIYA, A.; ALBERT, P.; SHINYA, T.; DESAKI, Y.; ICHIMURA, K.; SHIRASU, K.; NARUSAKA, Y.; KAWAKAMI, N.; KAKU, H. \& SHIBUYA, N. 2007. CERK1, a LysM receptor kinase, is essential for chitin elicitor signaling in 
Arabidopsis. Proceeds of the National Academy of Science USA, 104:1961319618.

MONACO, M.K.; STEIN, J.; NAITHANI, S.; WEI, S.; DHARMAWARDHANA, P.; KUMARI, S.; AMARASINGHE, V.; YOUENS-CLARK, K.; THOMASON, J.; PREECE, J.; PASTERNAK, S.; OLSON, A.; JIAO, Y.; LU, Z.; BOLSER, D.; KERHORNOU, A.; STAINES, D.; BRANDON, W.; WU, G.; D'EUSTACHIO, P.; HAW, R.; CROFT, D.; KERSEY, P.J.; STEIN, L.; JAISWAL, P. \& WARE, D. 2013. Gramene 2013: comparative plant genomics resources. Nucleic Acids Research 42: 1193-1199.

MONAGHAN, J. \& ZIPFEL, C. 2012. Plant pattern recognition receptor complexes at the plasma membrane. Current Opinion in Plant Biology, 15: 349-357.

MOU, Z.; FAN, W. \& DONG, X. 2003. Inducers of plant systemic acquired resistance regulate NPR1 function through redox changes. Cell 113: 935-944

OU, S.H. 1980. A look at worldwide rice blast disease control. Plant Disease. 64, 439445.

PARLEVIET, J.E. \& ZADOKS, J.C. 1977. The integrated concept of disease resistance: a new view including horizontal and vertical resistance in plants. Euphytica, 26: 5-21.

PIETERSE, C.M.J.; VAN WEES, S.C.M.; VAN PELT, J.A.; KNOESTER, M.; LAAN, R. \& GERRITS, H. 1998. A novel signaling pathway controlling induced systemic resistance in Arabidopsis. Plant Cell, 10: 1571-1580.

PIETERSE, C.M.J.; VAN PELT, J.A.; TON, J.; PARCHMANN, S.; MUELLER, M.J.; BUCHALA, A.J.; MÉTRAUX, J.P. \& VAN LOON, L.C. 2000. Rhizobacteriamediated induced systemic resistance (ISR) in Arabidopsis requires sensitivity to jasmonate and ethylene but is not accompanied by an increase in their production. Physiological and Molecular Plant Pathology, 57: 123-134. 
PIETERSE, C.M.J.; VAN WEES, S.C.M.; TON, J.; VAN PELT, J.A; Van LOON, L.C. 2002. Signalling in rhizobacteria-induced systemic resistance in Arabidopsis thaliana. Plant Biology, 4:535-544.

PIETERSE, C.M.J.; ZAMIOUDIS, C.; BERENDSEN, R.L.; WELLER, D.M.; Van WEES, S.C.M. \& BAKKER, P.A.H.M. 2014. Induced systemic resistance by beneficial microbes. Annual Review of Phytopathology 52:347-375.

PRABHU, A.S.; FILIPPI, M.C. \& ARAUJO, L.G. 2002. Pathotype diversity of Pyricularia grisea from improved upland rice cultivars in experimental plots. Fitopatologia Brasileira, 27: 468-473.

PRABHU, A.S., FILIPPI, M.C., SILVA, G.B., LOBO, V.L.S., MORAES, O.P., 2009. An unprecedented outbreak of rice blast on a newly released cultivar BRS Colosso in Brazil. In: Wang, G.L., Valente, B. (Eds.), Advances in Genetics, Genomics and Control of Rice Blast Disease. Springer, New York, pp. 257266.

RAJ, S.N.; LAVANYA, S.N.; AMRUTHESH, K.N.; NIRANJANA, S.R.; REDDY, M.S. \& SHETTY, H.S. 2012. Histo-chemical changes induced by PGPR during induction of resistance in pearl millet against downly mildew disease. Biological Control, 60:90-102.

RICHARD, A. \& TALBOT, N.J. 2009. Under pressure: investigating the biology of plant infection by Magnaporthe oryzae. Nature Reviews Microbiology 7:185195.

ROBERT-SEILANIANTZ，A.; GRANT, M. \& JONES, J.D.G. 2011. Hormone crosstalk in plant disease and defense: more than just JASMONATESALICYLATE antagonism. Annual Review of Phytopathology, 49:317-343.

RUDRAPPA, T.; CZYMMEK, K.J.; PARE, P.W. \& BAIS, H.P. 2008. Root-secreted malic acid recruits beneficial soil bacteria. Plant Physiology, 148:1547-1556. 
SCHWAN-ESTRADA, K.R.F.; STANGARLIN, J.R. \& PASCHOLATI, S.F. 2008. Mecanismos bioquímicos de defesa vegetal. In: Pascholati SF, Leite B, Stangarlin JR, Cia P (Eds). Interação planta-patógeno - fisiologia, bioquímica e biologia molecular. Fealq. Piracicaba. p.227-248.

SCHWESSINGER, B. \& ZIPFEL, C. 2008. News from the frontline: recent insights into PAMP-triggered immunity in plants. Current Opinion in Plant Biology, 11:389-395.

SHIMONO, M.; KOGA, H.; AKAGI, A.; HYASHI, N.; GOTO, S.; SAWADA, M.; KURIHARA, T.; MATSUSHITA, A.; SUGANO, S.; JIANG, C.J.; KAKU, H.; INOUE, H. \& TAKATSUJI, H. 2012. Rice WRKY45 plays important roles in fungal and bacterial disease resistance. Molecular Plant Pathology, 13:83-94.

SUGANO, S.; JIANG, CJ.; MIYAZAWA, SI.; MASUMOTO, C.; YAZAWA, K.; HAYASHI, N.; SHIMONO, M.; NAKAYAMA, A.; MIYAO, M. \& TAKATSUJII, H. 2010. Role of OsNPR1 in rice defense program as revealed by genome-wide expression analysis. Plant Molecular Biology 74:549-562.

TRUMAN, W.; BENNETT, M.H.; KUBIGSTELTIG, I.; TURNBULL, C. \& GRANT, M. 2007. Arabidopsis systemic immunity uses conserved defense signaling pathways and is mediated by jasmonates. Proceedings of the National Academy of Sciences USA, 104:1075-1080.

VAN DER ENT, S.; VAN WEES, S.C.M. \& PIETERSE, C.M.J. 2009. Jasmonate signaling in plant interactions with resistance-inducing beneficial microbes. Phytochemistry, 70:1581-1588.

VAN LOON, L.C. \& VAN STRIEN, E.A. 1999. The families of pathogenesis related proteins, their activities, and comparative analysis of PR-1 type proteins. Physiology Molecular Plant Pathology. 55:85-97. 
VAN LOON, L.C. \& BAKKER, P.A.H.M. 2006. Root-associated bacteria inducing systemic resistance. In: Gnanamanickam, S.S. (Ed.), Plant-Associated Bacteria. Springer, Dordrecht, p.269-316.

VERBERNE, M.C.; HOEKSTRA, J.; BOL, J.F. \& LINTHORST, H.J.M. 2003. Signaling of systemic acquired resistance in tobacco depends on ethylene perception. Plant Journal, 35:27-32.

VERHAGEN, B.A.S.W.M.; VAN LOON, L.C. \& PIETERSE, M.J. 2006. Induced Disease Resistance Signaling in Plants. Floriculture, Ornamental and Plant Biotechnology 3:334-343.

WALTERS, D.R.; RATSEP, J.; HAVIS, N.D. 2013. Crontrolling crop diseases using induced resistance: challenges for the future. Journal of Experimental Botany. 118.

WILLMANN, R.; LAJUNEN, H.M.; ERBS, G.; NEWMAN, M-A.; KOLB，D.; TSUDA, K.; KATAGIRI, F.; FLIEGMANN, J.; BONO, J-J. \& CULLIMORE, J.V. 2011. Arabidopsis lysin-motif proteins LYM1 LYM3 CERK1 mediate bacterial peptidoglycan sensing and immunity to bacterial infection. Proceed of the National Academy of Science USA, 108:19824-19829.

WILSON, R.A.; TALBOT, N.J. 2009. Under pressure: investigating the biology of plant infection by Magnaporthe oryzae. Nature Reviews of Microbiology, 7, $185-195$.

YANG, Z.; MA, H.; HONG, H.; YAO, W.; XIE, W.; XIAO, J.; LI, X. \& WANG, S. 2015. Transcriptome-based analysis of mitogen-actived protein kinase cascades in the rice response to Xanthomonas oryzae infection. Rice 8:4.

ZHU, Q.H.; STEPHEN, S.; KAZAN, K.; JIN, G.; FAN, L.; TAYLOR, J.; DENNIS, E.S.; HELLIWELL, C.A. \& WANG, M.B. 2013. Characterization of the defense transcriptome responsive to Fusarium oxysporum-infection in Arabidopsis using RNA-seq. Gene, 512:259-266. 
ZHU, S.; DAI, Y.M.; ZHANG, X.Y.; YE, J.R.; WANG, M.X. \& HUANG, M.R. $2013 b$. Untangling the transcriptome from fungus-infected plant tissues. Gene 519:238244.

ZHU, Y.J.; QIU, X.; MOORE, P.H.; BORTH, W.; HU, J.; FERREIRA, S. \& ALBERT, H.H. 2003. Systemic acquired resistance induced by BTH in papaya. Physiological and Molecular Plant Pathology, 63:237-248.

ZIPFEL, C.; KUNZE, G.; CHINCHILlA, D.; CANIARD, A.; JONES, J.D.G.; BOLLER, T.; FELIX, G. 2006. Perception of the bacterial PAMP EF-Tu by the receptor EFR restricts Agrobacterium-mediated transformation. Cell, 125: 749760. 


\section{CAPÍTULO 1}

Evaluation of rhizobacteria in upland rice in Brazil: growth promotion and induced defense responses interaction against leaf blast (Magnaporthe oryzae) 
1 Title: Evaluation of rhizobacteria in upland rice in Brazil: growth promotion

2 and induced defense responses interaction against leaf blast (Magnaporthe

3 oryzae)

4

5 Authors: Eugenio Miranda Sperandio ${ }^{a}$, Helson Mario Martins do Vale ${ }^{\mathrm{a}}$,

6 Marta Cristina Corsi de Filippi ${ }^{\mathrm{b}}$, Marcello de Souza Reis ${ }^{\mathrm{b}}$, Marcio Vinícius de

7 Carvalho Barros Cortes ${ }^{\mathrm{b}}$, Anna Cristina Lanna $\mathrm{b}$.

8

9 Author's affiliation: ${ }^{a}$ Departamento de Fitopatologia/Instituto de Ciências 10 Biológicas, Universidade de Brasília, Brasília, Distrito Federal, Brazil 11 70910-900. ${ }^{b}$ Embrapa Rice and Beans, Santo Antônio de Goiás, GO, Brazil 12 75375-000.

Author's

emails:

Eugenio

Miranda

Sperandio

(eugeniosperandio@gmail.com),

Helson Mario Martins do Vale

(helson@unb.br), Marta

Cristina

Corsi de

Filippi

(cristina.filippi@embrapa.br),

Marcello

de Souza

Reis (marcelloucg@hotmail.com), Marcio Vinícius de Carvalho Barros Cortes (marcio.cortes@embrapa.br), Anna Cristina Lanna (anna.lanna@embrapa.br)

To whom correspondence should be addressed:

Helson Mario Martins do Vale

Departamento de Fitopatologia/Instituto de Ciências Biológicas

Universidade de Brasília, Campus Universitário Darcy Ribeiro, Asa Norte,

Brasília, Distrito Federal, Brasil - 70910-900

Email: helson@unb.br

Phone: +55(61)31073060

Fax: +55(61)31072931 
Abstract

Blast and initial vigor of upland rice plants are the main challenges this crop faces in Brazilian no-tillage systems. The aim was to evaluate the growth promotion and defense responses against Magnaporthe oryzae in rice plants treated with rhizobacteria Bacillus sp. (BRM 32110) and Serratia sp. (BRM 32114) and to identify the causes of variance related to induced resistance effectiveness. Seeds of rice were microbiolized, and 14 days after emergence the soil was drenched with rhizobacteria suspensions. Growth promotion was evaluated by root and shoot biomass, root and shoot length, foliar area and nitrate reductase (NR) activity. The defense response was evaluated by quantification of rice blast severity (RBS), disease progress, pathogenesisrelated proteins (PRP) activity, and contents of salicylic acid (SA). Length and biomass of roots and shoots and foliar area of plants treated with BRM 32114 isolate increased, however, the NR activity was $43 \%$ lower, compared to control. Both isolates reduced severity and disease progress. Principal component analyses showed that RBS, $\beta$-1,3-glucanase (GLU), Peroxidase $(\mathrm{POX})$ and Phenylalanine ammonia lyase (PAL) were the main sources of the first components of variance, while lipoxygenase (LOX) and SA were the main sources of the second components and were negatively correlated. Serratia sp. isolate BRM 32114 can be used as a growth-promoting agent and has potential to induce resistance in rice plants. Results suggest that the interaction among levels and timing of activity of PRPs and the levels of SA play an important role in the defense responses against $M$. oryzae.

Keywords: rice blast, growth-promotion, induced resistance, pathogenesisrelated proteins, hormonal cross-talk.

\section{Introduction}

Plant Growth Promoting Rhizobacteria (PGPR) are beneficial microorganisms that inhabit the soil and actively participate in the nutritional dynamics of the soil. They influence the quality of ecosystems, making them important allies of sustainable agricultural production (Spaepen el al., 2009; Bhattacharya and Jha, 2012). PGPR increases the availability of nutrient 
synthesizing siderophores, stimulate the growth of roots and shoots (Nascimento et al., 2014) through the production of plant hormones such as auxin, cytokinins and gibberellins (Spaepen el al., 2009), and protect the plants against pathogen attack (Anith et al., 2004; Baysal et al., 2008; Mirik et al., 2008; Filippi et al., 2011).

Rhizobacteria act against pathogens through the production of antimicrobial compounds (Bhattacharya and Jha, 2012), competition for space and nutrients, and resistance induction (IR) (Lugtenberg and Kamilova, 2009). Contact between the plant and rhizobacteria activates the defense of the plant, which is called induced systemic resistance (ISR) (Kuc, 1982). In ISR, the plant shows increased production of reactive oxygen species (ROS), activity of proteins related to pathogenesis (PRP) and accumulation of phytoalexins as well as callose and lignin deposition in the plant cell wall. Many of these responses are regulated by cross-communication between plant hormones, such as salicylic (SA), jasmonic (JA) acid and their derivatives, and the central roles they play in defense responses (De Vleesschauwer et al., 2013).

Rice is one of the most important crops in the world and is a staple food for over half the world's population (Zeigler and Barclay, 2008). The cultivation of upland rice, or aerobic rice, has expanded in Brazil and is growing in global importance due to reduced availability of water resources and increases in industrial and human consumption (Nascente et al., 2011). However, two challenges facing increased upland rice yields are the low response of cultivars to nitrogen fertilization (Nascente et al., 2011; Lanna and Carvalho, 2013) and the high incidence of diseases (Ou, 1987). Rice blast caused by the fungus Magnaporthe oryzae is the major disease affecting this crop and is a huge threat to food security worldwide (Wilson and Talbot, 2009; Fisher et al., 2012).

A susceptible rice crop may be infected by $M$. oryzae in the vegetative and reproductive phases. In the vegetative stage, the lesions increase in size and number, reducing the photosynthetic area of the plant. The panicles may also be infected, preventing grain filling and causing serious consequences for production (Jeon et al., 2007; Talbot, 2003). When weather conditions are 
favorable for disease development, losses caused by the blast can reach $100 \%$ of the crop, even in cultivars with resistance genes (Prabhu et al., 2009).

Although genetic resistance of the host is the most viable and economically practical, it may no longer be effective after a few crop cycles, rapidly being overtaken due to the emergence of new races of pathogens. In a sustainable scenario for agriculture, control of rice blast requires integrated methods for effective and environmentally friendly control by reducing the use of pesticides (Ou, 1980). In this sense, beneficial rhizobacteria emerge as an alternative to agricultural inputs like fertilizers and pesticides for growing rice and allow for a reduction of environmental and health risks (Ahemad and Kibret, 2014).

This study aimed to investigate the effect of the PGPRs, BRM 32110 and BRM 32114 in growth promotion and leaf blast suppression, to analyze the interactions among relevant variables, and to understand the network of defenses of upland rice plants.

\section{Material and Methods}

Two experiments were conducted in order to evaluate growth promotion: one in laboratory and one in greenhouse. The third was conducted in greenhouse and quantified the suppression of leaf blast as a result of increases in the activity of enzymes and hormone levels related to plant defense.

\subsection{Growth promotion}

Shoot and root length data were obtained 10 days after sowing, and root and shoot biomass and nitrate reductase activity (NR) were recorded 24 days after emergence (DAE). The experimental units were outlined in a randomized complete block design with ten repetitions per treatment. Ten plants per treatment were evaluated.

\subsubsection{Rhizobacteria BRM 32110 and BRM 32114 suspension}


Rhizobacteria used in this study were isolated from rhizosphere of rice fields of cultivar BRS Primavera in Paragominas City, PA, Brazil in the first year of planting. These rhizobacteria isolates belonged to the Multifunctional Microorganisms Embrapa Rice and Beans Collection and were labeled as BRM 32110 (Bacillus sp.) and BRM 32114 (Serratia sp.), GenBank accession numbers KX378746 and KX378747, respectively. An aliquot of 30 $\mu \mathrm{L}$ of each PGPR isolate was spread utilizing a Drigalsky handle in Petri dishes containing 523 culture medium (Kado and Heskett, 1970) and incubated at $28^{\circ} \mathrm{C}$ for $24 \mathrm{~h}$. The bacterial suspension was scratched from plates, suspended in destiled water and adjusted to $600 \mathrm{~nm}(\mathrm{~A} 600=0.1$, corresponding to $10^{8} \mathrm{CFU}$ per $\mathrm{mL}$ ) absorbance.

Seeds of upland rice cultivar BRS Primavera were sequentialy sterilized with $70 \%$ ethanol (for three $\min$ ) and $2 \%$ hypochlorite (for one bacterial suspension and shaken - $150 \mathrm{rpm}$ for $24 \mathrm{~h}$ ) and dried at room temperature prior to planting.

The treatments to evaluate growth promotion consisted of seeds microbiolized with BRM 32110 and BRM 32114 plus a negative control (seeds microbiolized with distilled water).

\subsubsection{Length of rice plants}

Rice seeds were sown into $9 \mathrm{ml}$ test tubes containing water-agar $(0.8 \%$ w/v). Tubes were placed in germination chambers at $28^{\circ} \mathrm{C}$ and 12 -hour photoperiod. The root and shoot length were measured utilizing a caliper ruler ten days after sowing. Ten tubes of each treatment were measured. Each assay tube contained a seed and constituted an experimental unit.

\subsubsection{Root and shoot biomass, foliar area and nitrate reductase activity}

Seeds were sown in plastic trays $(15 \times 30 \times 10 \mathrm{~cm})$ containing $3 \mathrm{~kg}$ of fertilized soil (5 $\mathrm{g}$ of 5-30-15 NPK mix $+1 \mathrm{~g}$ of $\mathrm{Zn}$ and $1 \mathrm{~g}$ of $\left(\mathrm{NH}_{4}\right)_{2} \mathrm{SO}_{4}$ ). Three trays were used per treatment. Each tray was composed of eight lines and each line consisted of 10 plants, totaling 80 plants per tray. They were 
kept under greenhouse conditions $\left(28^{\circ} \mathrm{C}, 60 \%\right.$ relative humidity and 12 -hour photoperiod).

Twenty one days after sowing, ten plant of each treatment were collected. Shoots and roots were removed and washed in running water, separated, placed in envelopes and dried in an oven at $70{ }^{\circ} \mathrm{C}$. After $72 \mathrm{~h}$, samples were weighed, and biomass was quantified. The foliar area was estimated using a digital scanner and performed immediately after collecting the leaves.

The determination of NR activity was performed according to Jaworski (1971) methodology with modifications. Fragments of rice leaves of approximately $0.5 \mathrm{~cm}^{2}$ were prepared for in vivo testing of NR activity. The cut tissue was weighed $(50 \mathrm{mg})$, transferred to microcentrifuge tubes and then added to $750 \mu \mathrm{L}$ of incubation solution (phosphate buffer $0.1 \mathrm{~mol} \mathrm{~L}^{-1}, \mathrm{pH} 7.5$, 2-propanol $(2 \%, \mathrm{v} / \mathrm{v})$ and potassium nitrate $\left.0.02 \mathrm{~mol} . \mathrm{L}^{-1}\right)$. After $35 \mathrm{~min}$ of incubation, the samples were taken to a water bath $\left(100{ }^{\circ} \mathrm{C}\right.$ for $\left.5 \mathrm{~min}\right)$ and then cooled. Five hundred microliters of sulfanilamide (1\%) and $500 \mu \mathrm{L}$ of $\mathrm{n}$ naphthyl-ethylenediamine $(0.02 \%)$ were then added, and the samples were incubated for $20 \mathrm{~min}$. The color intensity of the solution (formation of a pinkcolored complex) was measured at $540 \mathrm{~nm}$ in a spectrophotometer. Calibration curves were obtained from a standard stock solution $\left(100 \mu \mathrm{mol} . \mathrm{L}^{-}\right.$ 1 of $\left.\mathrm{NaNO}_{2}\right)$. The nitrite $\left(\mathrm{NO}_{2}^{-}\right)$content of the leaves was calculated with reference to the calibration graph and plotted from the results obtained with diluted standard solutions containing 0, 10, 20, 30, 40, 50, 60, 70, 80, 90 and

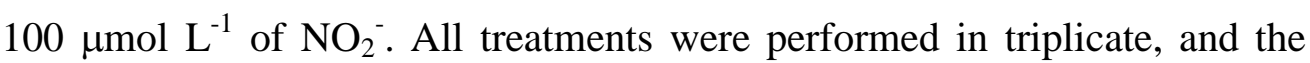
NR activity was expressed as $\mu \mathrm{mol} \mathrm{NO} \mathrm{N}^{-1} \mathrm{~g}^{-1} \mathrm{FW}$ (fresh weight).

\subsection{Leaf blast suppression}

Suspensions of rhizobacteria BRM 32110 and BRM 32114 were obtained according to item 2.1.1. Rice plants were drenched with $100 \mathrm{~mL}$ of bacterial suspension 10 DAE. Besides the treatments mentioned in item 2.1.1, new treatments were added: BRM $32110+M$. oryzae, BRM $32114+M$. oryzae and $M$. oryzae (positive control). The experiment was run in a 
complete randomized block design with ten replicates and the preparation of trays and planting was performed as described in item 2.1.3.

2.2.1. Challenge inoculation with Magnaporthe oryzae, rice blast severity (RBS) assessement and area under the disease progress curve (AUDPC)

The compatible $M$. oryzae isolate (labeled as 10900) to the cultivar Primavera was obtained from the Microorganism Multifunction Collection of Embrapa Rice and Beans. The fungus was pre-multiplicated in PDA (potatodextrose-agar) and then transferred into petri dishes containing oat medium (oat meal $2 \%$, dextrose $1.5 \%$, agar $1.5 \% \mathrm{w} / \mathrm{v}$ ), and incubated under continuous light at $28^{\circ} \mathrm{C}$ for colony growth. After 10 days of incubation, the mycelium of the grown colony was removed utilizing a sterilized glass rod (Filippi and Prabhu 2001). Next, the plates were maintained in a growth chamber at $28^{\circ} \mathrm{C}$ and $99 \%$ of humidity for 48 hours. The conidia were collected with a paint brush and sterilized water and adjusted to a concentration of $3 \times 10^{5}$ conidia.mL $\mathrm{m}^{-1}$ using a hemacytometer (Filippi and Prabhu 2001). Rice plants were challenged in V3 phenological stage (17 DAE) by spraying $20 \mathrm{~mL}$ of conidial suspension.

Thirty six plants of each treatment were previously marked to determine AUDPC. The percentage of leaf area affected by the blast was assessed using a rating scale from 0 to $82 \%$ of the leaf area affected (Notteghem (1981). The plants were evaluated at 1, 2, 3, 5 and 7 days postinoculation (DPI) of $M$. oryzae under controlled greenhouse conditions. The AUDPC was calculated based on the leaf blast severity using the trapezoid formula of disease progress curve with the following equation:

$$
\sum_{i=1}^{n-1}\left[\left(x_{i}+x_{i-1}\right) / 2\right]\left(t_{i}-t_{i-1}\right)
$$

where $x_{i}$ and $x_{i-1}$ are the means of disease severity at time $t_{i}$, corresponding to days post-inoculation; $t_{i}$ and $t_{i-1}$ are consecutive evaluation dates, and $t_{i}-t_{i-1}$ 
is equal to 1. The total AUDPC represents the sum of AUDPC for all plants evaluated for each treatment.

2.2.2. Determination of the activity of pathogenesis-related proteins and content of salicylic acid

The collected of shoots were done at 1,2 and 3 DPI. Ten shoots per treatment were collected at random to assay the enzymatic activity of pathogenesis-related proteins. They were immediately frozen using liquid nitrogen for subsequent use.

Samples were macerated in liquid nitrogen, and the buffer solution (Trish $10 \mathrm{mM}$; $\mathrm{NaCl}$ [150 $\mathrm{mm}$ ]; EDTA [2 $\mathrm{mm}$ ]; DTT [2 $\mathrm{mM}$ ]; PMFS [1 $\mathrm{mM}$ ]; Leptin $\left[10 \mu \mathrm{g} \cdot \mathrm{mL}^{-1}\right]$; Aprotinin $\left.\left[10 \mu \mathrm{g} \cdot \mathrm{mL}^{-1}\right]\right)$ was added to the samples. The content of total soluble proteins in the crude extract was measured according to the methodology of Bradford (1976) with bovine serum albumin (BSA) as the standard.

$\beta-1,3-$ Glucanase activity was measured according to methodology of Pan et al. (1991) by measuring the rate of reducing sugar production using laminarin as the substrate. Dinitrosalicylic acid (DNA) was used as the calorimetric agent. Activity of GLU was expressed in units per milligram of protein $\left(\mathrm{U}_{\mathrm{mg}} \mathrm{m}^{-1}\right)$. One unit of enzymatic activity was defined as the enzyme activity catalyzing the formation of reducing sugar that increases the absorbency of 1 unit of abs per hour.

Lipoxygenase activity was determined according to Axelrod et al. (1981) using linolenic acid as substrate. $50 \mu \mathrm{l}$ of rice shoot extracts were added in $2 \mathrm{~mL}$ of linoleic acid solution $(10 \mathrm{mM})$ in phosphate buffer $(50 \mathrm{mM}$, $\mathrm{pH} 6.0)(0,1 \% \mathrm{v} / \mathrm{v})$, at room temperature. The LOX activity was quantified in a spectrophotometer $(\lambda=234 \mathrm{~nm})$.

The activity of phenylalanine ammonia-lyase was measured by adding $50 \mu \mathrm{l}$ of rice shoot extracts from different treatments in $2 \mathrm{~mL}$ of phenylalanine solution $(10 \mathrm{mM})$ in borate buffer $(100 \mathrm{mM}, \mathrm{pH} 9.0)$. The mixture was homogenized and quantified in a spectrophotometer $(\lambda=290 \mathrm{~nm})$ (Côrtes et al., 2008). 
Peroxidase activity was assayed by measuring the rate of 2,2 '-azinobis (3-erthylbenzthiazoline-6-sulfonic acid) oxidation, using its own calorimetric property. One unit was defined as the enzyme activity catalyzing the formation of 2,2'-azino-bis (3-ethylbenzthiazoline-6-sulfonic acid) that increases the absorbency of 1 unit of abs per hour (Keesey, 1987).

For SA quantification in rice plants, $200 \mathrm{mg}$ of shoots from each treatment were macerated and transferred to microcentrifuge tubes $(2 \mathrm{~mL})$. One milliliter of methanol (90\%) was added to each well followed by stirring for 1 minute. The samples were centrifuged at $5000 \mathrm{rpm}$ for 10 minutes and transferred to a $15 \mathrm{ml}$ Falcon tube. One milliliter of methanol, $2 \mathrm{~mL}$ of trichloroacetic acid (5\%) and $2 \mathrm{~mL}$ of ethyl acetate, cyclopentane and isopropanol (50:50:1) were added to each tube. The samples were shaken for 1 minute, and the supernatant was transferred to another tube for lyophilization. To each tube was added $200 \mu \mathrm{L}$ of methanol (23\%) in acetate buffer (pH 5.0, $20 \mathrm{mM}$ ), which was filtered using a Millipore minifilter (0.45 $\mu \mathrm{m})$. The quantification of SA was carried out using HPLC (High Performance Liquid Chromatography) with a 4.8 minute retention time (Saikia et al., 2006; Meher et al., 2012.)

\subsection{Statistical analysis}

Statistical analysis was carried out with software SPSS (version 16.0), and the means were compared with Tukey's test $(p=0.05)$.

Principal components analysis (PCA) was performed to assess the multivariate effect of each variable related to plant defense responses and disease severity. The PCA tested induced resistance variables (PAL, LOX, GLU, POX, SA) with RBS and DPI. The PCA was performed using Rcmdr and FactormineR packages from 'R' software 2.15 ( $\mathrm{R}$ Development Core Team, Vienna, Austria).

\section{Results}

\subsection{Growth promotion}



other treatments in all evaluated parameters. There were increases of $41.9 \%$ and $43.4 \%$ in root (Fig. 1c) and shoot lengths, respectively, and increases of $46.5 \%$ in root biomass and $70 \%$ in shoot biomass (Table 1) when compared to control treatments. The foliar area was $23.64 \%$ greater in rice plants treated with the same isolate. Both PGPR isolates used in this study had no negative effects on seed germination (data not shown). The NR activity on plants treated with the isolates BRM 32114 and BRM 32110 were $43 \%$ and 62\%, lower than the control, respectively.

FIG. 1

\subsection{Leaf blast suppression}

The positive control treatment presented $35 \%$ of the leaf area affected by blast, which was significantly higher than other treatments (Fig. 2) at 7 days after challenge inoculation (Figure 2). The treatment with Bacillus sp. isolate BRM 32110 and Serratia sp. isolate BRM 32114 reduced the RBS by $40 \%$ and $35 \%$, respectively, compared to the control (M oryzae).

Fig1. Root growth of rice seedling 10 days after planting. Seeds were microbiolized with water (A and D), with isolate BRM 32110 (B and E) and BRM 32114 (C and F) and transferred to test tubes containing water-agar medium $(0.8 \% \mathrm{w} / \mathrm{v})(\mathrm{bar}=5 \mathrm{~mm})$.

\section{0\% and $35 \%$, respectively, compared to the control (M oryzae).}

9

Fig. 2 Area under the disease progress curve (AUDPC) of three different treatments: control (diamond): seeds microbiolized and plants drenched with water only and sprayed inoculated with $M$. oryzae conidial suspension; BRM 32110 (square): seeds microbiolized and plants drenched with BRM 32110 suspension and sprayed inoculated with $M$. oryzae conidial suspension; BRM 32114 (triangle): seeds microbiolized and plants drenched with BRM 32114 suspension and sprayed inoculated with $M$. oryzae conidial suspension. The bars above and below show maximum and minimum values of disease severity, respectively. Curves followed by the same letter are not statistically different by Tukey $(p=0,05)$ test. 
There was an increase of GLU activity at 1 and 3 DPI in plants treated with the isolate BRM 32114 and at 2 DPI in plants treated with BRM 32110 compared to controls $\left(\mathrm{H}_{2} \mathrm{O}\right)$. There was no difference in LOX activity among the treatments (Table 2). On the other hand, PAL activity was higher in plants treated with BRM 32110 at 1 DPI. POX activity at 1 DPI was higher in the controls. However, at 2 and 3 DPI, the highest POX activities were observed in BRM32110 and BRM 32114 treated plants, respectively.

SA levels were higher in plants treated with BRM 32114 at 1 and 2 DPI. The contents of SA were higher in plants treated with BRM 32110 at 3 DPI.

\subsubsection{In the presence of $M$. oryzae}

Plants that were induced and challenged with the pathogen (BRM $32114+$ M. oryzae and BRM $32110+$ M. oryzae), presented higher GLU activity that was significantly different from controls, which were only challenged with $M$. oryzae, on the third day $(\mathrm{p}=0.05)$. The LOX activity was higher in plants only challenged with $M$. oryzae in every analysis. However, plants induced with isolate BRM 32114 and challenged by the pathogen showed an increase in LOX activity from the first to the third rated day ( $p=$ 0.05). The control treatment (M. oryzae) showed the highest PAL activity in 1 DPI. In 2 DPI, the greatest activity was observed in treatment BRM $32110+$ M. oryzae, while in the $3 \mathrm{DPI}$, the highest activity was observed in 32114 BRM $+M$. oryzae treatment. From 1 to 2 DPI, PAL activity increased significantly in induced and challenged plants (Table 2) as well as in control plants $\left(\mathrm{H}_{2} \mathrm{O}\right)$. The POX activity was higher in the $M$. oryzae treatment at all times analyzed except in 2 DPI, in which plants that were induced and challenged presented the same level of POX activity than plants that were only challenged. Salicylic acid levels in induced plants were higher than in control plants $(\mathrm{H} 2 \mathrm{O})$ in each of the three analyses. At 1 DPI, the plants treated with BRM $32110+M$. oryzae presented the highest levels of SA. However, over the next days, the plants induced by BRM 32114 and challenged by $M$. oryzae also showed the highest levels of SA. 
Table 1. Length and biomass of roots and shoots, leaf area and Nitrate Reductase activity in leaves of rice plants treated with rhizobacteria BRM 32110 and BRM 32114.

\begin{tabular}{lccccc}
\hline Treatment & Root length $^{\mathrm{a}}$ & Shoot length $^{\mathrm{a}}$ & Root biomass $^{\mathrm{b}}$ & Shoot biomass $^{\mathrm{b}}$ & ${\text { Foliar } \text { area }^{\mathrm{c}}}^{\text {Nitrate reductase activity }^{\mathrm{d}}}$ \\
\hline BRM 32110 & $70.18 \mathrm{a}$ & $43.85 \mathrm{a}$ & $33.22 \mathrm{a}$ & $92.3 \mathrm{a}$ & $11.74 \mathrm{a}$ \\
BRM 32114 & $101.23 \mathrm{~b}$ & $60.8 \mathrm{~b}$ & $49 \mathrm{~b}$ & $136.7 \mathrm{~b}$ & $16.84 \mathrm{c}$ \\
$\mathrm{H}_{2} \mathrm{O}$ & $71.34 \mathrm{a}$ & $42.4 \mathrm{a}$ & $33.44 \mathrm{a}$ & $80.4 \mathrm{a}$ & $13.62 \mathrm{~b}$ \\
\hline
\end{tabular}

Mean values $(\mathrm{n}=10)$. Means followed by the same letter are statistically similar, according to Tukey test $(\mathrm{p}=0,05)$.

${ }^{\mathrm{a}} \mathrm{mm}$;

${ }^{b}$ mg of dry weight;

${ }^{\mathrm{c}} \mathrm{cm}^{2}$;

${ }^{\mathrm{d}} \mu \mathrm{mol} \mathrm{NaNO}{ }_{2} \cdot \mathrm{h}^{-1} \cdot \mathrm{g}^{-1} \mathrm{FW}$.

Table 2. proteins related to pathogenesis activity of $\beta$-1,3-glucanase (Glu), lipoxygenase (LOX), phenylalanine ammonia lyase (PAL), peroxidase (POX) and salicylic acid contents (SA), in upland rice plants treated with the rhizobacteria followed, or not, by challenge inoculation with $M$. oryzae

\begin{tabular}{|c|c|c|c|c|c|c|c|}
\hline \multirow[b]{2}{*}{ Variables } & \multirow[b]{2}{*}{$\mathbf{D P I}^{\mathbf{a}}$} & \multicolumn{6}{|c|}{ Treatments } \\
\hline & & BRM 32114 & BRM 32110 & $\mathrm{H}_{2} \mathrm{O}$ & BRM 32114 + M. oryzae & BRM 32110 + M. oryzae & M. oryzae \\
\hline \multirow{3}{*}{$\mathrm{GLU}^{\mathrm{b}}$} & 1 & $12.74 \mathrm{bC}$ & $9.60 \mathrm{aAB}$ & $9.92 \mathrm{bAB}$ & $10.41 \mathrm{bB}$ & $8.85 \mathrm{bA}$ & $9.59 \mathrm{bAB}$ \\
\hline & 2 & $8.93 \mathrm{aAB}$ & $32.57 \mathrm{bC}$ & $9.62 \mathrm{aAB}$ & $9.00 \mathrm{aAB}$ & $7.59 \mathrm{aA}$ & $11.71 \mathrm{cB}$ \\
\hline & 3 & $19.13 \mathrm{cC}$ & $7.57 \mathrm{aA}$ & $10.15 \mathrm{cB}$ & $10.05 \mathrm{bB}$ & $8.91 \mathrm{bAB}$ & $7.78 \mathrm{aA}$ \\
\hline \multirow{3}{*}{$\mathrm{LOX}^{\mathrm{b}}$} & 1 & $13.1 \times 10^{-5} \mathrm{aAB}$ & $10.3 \times 10^{-5} \mathrm{aAB}$ & $22.7 \times 10^{-5} \mathrm{aB}$ & $7.1 \times 10^{-5} \mathrm{aA}$ & $10 \times 10^{-5} \mathrm{aA}$ & $110 \times 10^{-5} \mathrm{cC}$ \\
\hline & 2 & $46.5 \times 10^{-5} \mathrm{cD}$ & $12.9 \times 10^{-5} \mathrm{aBC}$ & $48.2 \times 10^{-5} \mathrm{bD}$ & $14.3 \times 10^{-5} \mathrm{bA}$ & $29 \times 10^{-5} \mathrm{bB}$ & $37 \times 10^{-5} \mathrm{aC}$ \\
\hline & 3 & $29.3 \times 10^{-5} \mathrm{bA}$ & $60.9 \times 10^{-5} \mathrm{bBC}$ & $58.6 \times 10^{-5} \mathrm{bB}$ & $58.7 \times 10^{-5} \mathrm{cBC}$ & $25 \times 10^{-5} \mathrm{abA}$ & $69 \times 10^{-5} \mathrm{bC}$ \\
\hline \multirow{3}{*}{$\mathrm{PAL}^{\mathrm{b}}$} & 1 & $12 \times 10^{-5} \mathrm{bB}$ & $20.6 \times 10^{-5} \mathrm{cE}$ & $17.2 \times 10^{-5} \mathrm{aD}$ & $10 \times 10^{-5} \mathrm{aB}$ & $5 \times 10^{-5}$ aA & $13 \times 10^{-5} \mathrm{bC}$ \\
\hline & 2 & $23 \times 10^{-5} \mathrm{cD}$ & $5.6 \times 10^{-5} \mathrm{aA}$ & $30.1 \times 10^{-5} \mathrm{bE}$ & $14.4 \times 10^{-5} \mathrm{bC}$ & $25 \times 10^{-5} \mathrm{cD}$ & $9.1 \times 10^{-5} \mathrm{aB}$ \\
\hline & 3 & $10.4 \times 10^{-5} \mathrm{aA}$ & $11.6 \times 10^{-5} \mathrm{bA}$ & $40 \times 10^{-5} \mathrm{cB}$ & $12 \times 10^{-5} \mathrm{aA}$ & $11 \times 10^{-5} \mathrm{bA}$ & $12 \times 10^{-5} \mathrm{bA}$ \\
\hline \multirow{3}{*}{$\mathrm{POX}^{\mathrm{b}}$} & 1 & $11.96 \times 10^{-2} \mathrm{aB}$ & $11 \times 22.10^{-2} \mathrm{aAB}$ & $15.23 \times 10^{-2} \mathrm{bC}$ & $12.48 \times 10^{-2} \mathrm{bB}$ & $9.97 \times 10^{-2} \mathrm{aA}$ & $20.91 \times 10^{-2} \mathrm{cD}$ \\
\hline & 2 & $12.02 \times 10^{-2} \mathrm{aB}$ & $30.23 \times 10^{-2} \mathrm{bE}$ & $20.52 \times 10^{-2} \mathrm{cD}$ & $10.46 \times 10^{-2} \mathrm{aA}$ & $14 \times 40.10^{-2} \mathrm{bC}$ & $14.65 \times 10^{-2} \mathrm{aC}$ \\
\hline & 3 & $26.02 \times 10^{-2} \mathrm{bD}$ & $11.28 \times 10^{-2} \mathrm{aA}$ & $13.11 \times 10^{-2} \mathrm{aB}$ & $13.73 \times 10^{-2} \mathrm{bB}$ & $10.48 \times 10^{-2} \mathrm{aA}$ & $16.73 \times 10^{-2} \mathrm{bC}$ \\
\hline \multirow{3}{*}{$\mathrm{SA}^{\mathrm{c}}$} & 1 & $975.00 \mathrm{cD}$ & $881.67 \mathrm{bB}$ & $809.33 \mathrm{aA}$ & $1040.67 \mathrm{cE}$ & $1050.33 \mathrm{cF}$ & $906.00 \mathrm{cC}$ \\
\hline & 2 & $950.00 \mathrm{bD}$ & $692.33 \mathrm{aA}$ & $938.33 \mathrm{bD}$ & $1002.67 \mathrm{bE}$ & $846.67 \mathrm{aC}$ & $805.67 \mathrm{aB}$ \\
\hline & 3 & $864.67 \mathrm{aB}$ & $897.67 \mathrm{cC}$ & $809.33 \mathrm{aA}$ & $924.00 \mathrm{aD}$ & $867.00 \mathrm{bB}$ & $806.00 \mathrm{bA}$ \\
\hline $\mathrm{RBS}^{\mathrm{a}}$ & - & - & - & - & $23 \mathrm{~A}$ & $21 \mathrm{~A}$ & $35 \mathrm{~B}$ \\
\hline
\end{tabular}
$23 \mathrm{~A}$ $35 \mathrm{~B}$

377 .Means followed by the same capital letters (rows) are statistically similar according to the Tukey test $(\mathrm{p}=0.05)$

$378{ }^{\mathrm{a}} \mathrm{DPI}=$ days post inoculation. 
${ }^{\mathrm{b}}$ Leaf blast severity was measured according to a rating scale ranging from 0.5 to $82 \%$ of the affected. leaf area.

${ }^{\mathrm{c}}$ U.mg- ${ }^{1},{ }^{\mathrm{c}}$ ng.g- ${ }^{-}$. 


\subsection{Principal component analysis}

The principal component analysis showed that the first two components were responsible for $47.63 \%$ (PCA 1) and $23.65 \%$ (PCA 2) of the observed variance, making a total of $71.28 \%$ (Fig. 3). We believe that the first and second components provide sufficient information to support most of the results obtained. The protein variables related to the pathogenesis, salicylic acid content and leaf blast severity were responsible for most of the data variance.

The PAL activity was negatively correlated with GLU and POX activity, SA contents, rice blast severity and days post-inoculation. Much of this variance is explained by PCA 1. Such correlations indicate that PAL plays a key role in the metabolic pathways of these defense proteins (GLU and POX) as well as salicylic acid by getting involved in the early stages of hormone synthesis and in the cascade of events related to these enzymes. LOX was negatively correlated with SA, indicating that LOX and SA have antagonistically reciprocal effects upon each other, playing a key role in the regulation of one another. Both showed a clear influence upon the variance, and together with the SA, LOX showed a strong association with the second main component (Table 3).

FIG. 3

Fig. 3 Principal Component Analyses plot with induced resistance variables investigated for control of rice blast (M. oryzae) by plant growth-promoting rhizobacteria.

Table 3. Correlation matrix of variables related to induced resistance in rice to control rice blast (Magnaporthe oryzae) by BRM 32114 and BRM 32110 isolates and dimensions of principal component analysis with significance of $p<0.05$.

\begin{tabular}{lcc}
\hline \multicolumn{1}{c}{ Variables } & PCA1 & PCA2 \\
\hline Rice blast severity & 0,86 & NS \\
Days post inoculation & 0,858 & NS \\
B-1,3 Glucanase & 0,829 & NS \\
Peroxidase & 0,691 & NS \\
Phenylalanine ammonia-lyase & $-0,802$ & NS \\
Lipoxygenase & NS & 0,766 \\
Salicylic acid & NS & $-0,875$ \\
Explained Variance & $47,63 \%$ & $23,65 \%$ \\
Cumulative Variance & $47,63 \%$ & $71,28 \%$ \\
\hline NS = not significant at $p<0,05$. & &
\end{tabular}




\section{Discussion}

The results suggested that the isolate BRM 32114 stimulated the growth of upland rice plants because the length and dry weight of roots and shoots of plants treated with BRM 32114 were higher than in plants treated with BRM 32110 and control conditions (water) (Table 1). The gain in size and plant biomass can be explained due to the characteristics of the isolate 32114 BRM, which synthesizes indoleacetic acid and solubilizes phosphate (Martins, 2015). Some rhizobacteria have the ability to produce a variety of biologically active compounds (enzymes, vitamins, amino acids and plant hormones) that have active stimulating effect on plant growth and development (Larsen et al., 2009; Filippi et al., 2011; Bhattacharya et al., 2012; Dawwam et al., 2013). These results are relevant for agriculture and especially for rice grown in uplands under no-tillage systems with a lower performance and productivity when compared to flooded rice (Nascente et al., 2011). Statistically, there were no significant differences between the NR activities among treatments with rhizobacteria; however, the NR activities were lower than in control plants (Table 1). The NR enzyme catalyzes nitrate reduction to nitrite and represents the first step in the nitrogen assimilation pathway in the form of nitrate ions $\left(\mathrm{NO}_{3}{ }^{-}\right)$of organic components such as glutamate (Konishi and Yanagisawa 2011; Nemie-Feyissa et al., 2013). The low levels of NR activity in microbiolized and watered plants, especially on the treated plants with BRM 32114, may be attributed to the fact that the presence of rhizobacteria on the medium promoted $\mathrm{N}$ supply in the form of ammonium ions $\left(\mathrm{NH}_{4}{ }^{+}\right)$, which would prevent the upland rice plants from expending energy to reduce nitrate. This can be confirmed with growth data because the plants with the lowest NR values were the ones that showed the highest values in the analyzed growth promotion parameters (Table 1).

In addition to promoting the growth of plants, PGPRs can help in reducing disease severity because they produce antimicrobial compounds and/or induce resistance mechanisms (Son et al., 2014; Qin et al., 2015). In this study, the development of leaf blast was reduced on the plants treated with rhizobacteria. The disease progression indicates that treatment of the plants with inducer microorganisms enable the plant to react against pathogen invasion by activating defense mechanisms against $M$. oryzae more efficiently than untreated plants. Similar results were also reported in rice plants (Filippi et al., 2011), peppers (Son et al., 2014), chickpeas 
442 (Verma et al., 2014) and several other crops (Zaidi et al., 2015), suggesting an inducer role of PGPR in plant defense mechanisms against various diseases.

The treatment of plants with rhizobacteria resulted in differences in the levels of PRPs activity and SA content compared to plants that were only challenged with $M$. oryzae. The activity of $\beta$-1,3-glucanase was higher in plants treated with PGPR and not challenged with the pathogen. This enzyme belongs to the PR2 class from the PRP family and is known to inhibit the mycelial growth of a broad range of fungi (Nishizawa et al., 2003); it also plays a key role in cell division during the passage of cellular materials by plasmodesmata and during flower formation (Balasubramanian et al., 2012). Despite the fact that treatments receiving only rhizobacteria had shown an increase of lytic enzyme activity, in the presence of pathogens, these plants maintained constant GLU activity levels, with a small change occurring during the evaluation period. The activity was not significantly different from the positive control (M. oryzae) except at 3 DPI (BRM $32114+$ M. oryzae).

The highest LOX activity was observed at 1 DPI in plants that were only challenged with the pathogen. In the treatment that presented the lowest rates of RBS (BRM $32114+$ M. oryzae), the increase of LOX activity was gradual and continuous during the measured periods, with the highest level of activity occurring in the last day analyzed (Table 2). Similar results were obtained by Hao et al., (2009) when analyzing defense responses in the same pathosystem. LOX are isoenzymes that catalyze the oxidation of polyunsaturated fatty acids and are the first enzymes activated in the metabolic pathway of the defense hormone jasmonic acid (Wang et al., 2008). This hormone has a key role in plant defense responses against $M$. oryzae, especially in necrotrophic phase of colonization, which happens after penetration and initial phase of colonization (biotrophic) (Dean et al., 2012; De Vleesschauwer et al., 2013).

The PAL activity began to increase in the first 48 hours after challenge inoculation at 2 DPI. This is important in defense responses because PAL is the first enzyme of the phenyl-propanoid pathway and has important functions in plants exposed to environmental stresses and pathogen attacks. It is also involved in the synthesis of salicylic acid, phenolics and phytoalexins (Minami et al., 1989).

After induction, increases in POX activity were greater in non-challenged plants than in challenged ones. Only at 1 DPI were POX levels higher in the challenged plants (Table 2). The activity of enzymes related to oxidative stress may be modified by the use of rhizobacteria (García-Cristobal et al., 2015), and these differences may be 
attributed to the interaction between rhizobacteria and upland rice plants (Bais et al., 2006).

The leaf blast suppression was observed in rice plants treated with the rhizobacteria, in the form of low disease rates and higher levels of salicylic acid. It is well established that SA plays a key role in signaling of defense mechanisms, in rice and other plants, leading to the increased PRPs activities as well as other biochemical defense responses, such as the accumulation of phenolic compounds and phytoalexins (De Vleesschauwer et al., 2013). In this work, the plants with higher salicylic acid content were not necessarily the plants that presented the higher defense protein activities; however, they had the lowest disease rates.

Multivariate analysis showed how induced mechanisms involved in defense responses may contribute to a more effective response against pathogen attacks and thus prevent or lessen the severity of the disease. Isolates of PGPR with the potential for the promotion and induction of resistance of rice against $M$. oryzae have been characterized as inducing pathogenesis-related protein activities (Filippi et al., 2011) and increasing defense hormone levels; however, this analysis becomes more complex because other PRPs are being quantified.

PCA analyses allowed for an exploratory interpretation of many variables together as only two components summarized $71.28 \%$ of all data variance. The variable DPI is strongly correlated with increasing disease severity as expected, and with the increase in POX and GLU activities, which may be attributed to the presence of the pathogen and the continued progress of the disease (Figure 2). The PAL activity decreased as the activity of other PRPs in the PCA1 increased. Unlike the PRPs from PCA1, PAL is not an enzyme that acts directly on the pathogen, but rather is a key signal in a number of other metabolic pathways and compounds related to plant defense.

Salicylic acid was negatively correlated with LOX (Table 3). This enzyme is the precursor in the jasmonic acid pathway and is one of the most studied examples of cross-talk signals between SA and JA (De Vleesschauwer et al., 2013) pathways where the main interaction between them is antagonistic (Thaler et al., 2012). In rice, SA is predominantly associated with resistance to biotrophic pathogens, while JA is associated with defense responses against necrotrophic pathogens (Pieterse et al., 2009; Robert- Seilaniantz et al., 2011). M. oryzae presents two types of colonization and, therefore, is a hemibiotrophic fungus (De Vleesschauwer et al., 2013). The colonization of the plant begins with appressoria formation followed by intercellular colonization in 
host cells. With the death of the colonized cells, the fungus begins to nourish itself with dead cells, starting the necrotrophic phase of infection (Dean et al., 2012).

In the present study, SA levels were higher in plants treated with rhizobacteria and challenged with $M$. oryzae in the first 24 hours and decreased over time, especially for the treatment BRM $32114+$ M. oryzae. This treatment showed a significant increase in LOX activity on the last evaluation day (3 DPI), suggesting that an increase of JA content occurs when the content of SA diminishes; an alternative is that JA levels might trigger the decrease in SA. This demonstrates how essential SA is in the early hours after onset of infection in this pathosystem and also suggests that other metabolic pathways such as the jasmonates may be associated with defense responses in this pathosystem. These results illustrate the complexity of plant defense responses against pathogen attack and that numerous mechanisms that may be activated in different periods of infection. Identifying joint actions and their interactions may be the best key to understanding the defense mechanisms induced by PGPRs.

\section{Conclusions}

Isolate BRM 32114 showed beneficial effects by increasing root and shoot biomass, lengths and foliar area in the upland rice cultivar BRS Primavera. Both PGPR isolates enhanced GLU activity in rice plants. Plants treated with BRM 32114 and challenged with $M$. oryzae presented the highest levels of salicylic acid, indicating that this phytohormone may be used as a biochemical marker to select further resistance inducers in rice.

The principal component analysis offered an appropriate approach for indicating the importance of each of the evaluated variables and for establishing the correlation among them during resistance induction.

\section{Acknowledgements}

The authors would like to thank the National Council for Scientific and Technological Development (CNPq) and the Foundation for Research Support of Federal District (FAP-DF) for financial support.

\section{References}


545 Ahemad, M., Kibret, M., 2014. Mechanisms and applications of plant growth promoting

\author{
rhizobacteria: Current perspective. J. King Saud. Univ. Sci. 26, 1-20.
}

Anith, K.N., Momol, M.T., Kloepper, J.W., Marois, J.J., Olson, S.M., Jones, J.B., 2004. Efficacy of plant growth-promoting rhizobacteria, acibenzolar-S-methyl, and soil amendment for integrated management of bacterial wilt on tomato. Plant. Dis. 86,156161.

Axelrod, B.C., Cheesbrough, T.M., Laasko, S.L., 1981. Lipoxygenase from soybean. Method. Enzymol. 71, 441- 451.

Bais, H.P., Weir, L.T., Perry, L.G., Gilroy, S., Vivanco, J.M., 2006. The role of root exudates in rhizosphere interaction with plants and other organisms. Annu. Rev. Plant Biol. 57, 233-266.

Balasubramanian, V., Vashisht, D., Cletus, J., Sakthivel, N., 2012. Plant $\beta-1,3-$ glucanases: their biological functions and transgenic expression against phytopathogenic fungi. Biotchnol. Lett. 34, 1983-1990.

Baysal, Ö., Caliskan, M., Yesilova, Ö., 2008. An inhibitory effect of a new Bacillus subtilis strain (EU07) against Fusarium oxysporum f.sp. radicis-lycopersici. Physiol. and Mol. Plant Path. 73, 25-32.

Bhattacharya, P.N., Jha, D.K., 2012. Plant growth promoting rhizobacteria (PGPR): emergence in agriculture. World J. Microb. Biot. 28, 1327-1350.

Bradford, M., 1976. A rapid and sensitive method for the quantification of microgram quantities of protein utilizing the principle of protein-dye binding. Anal Biochem. 72, 248-254.

Côrtes, M.V.C.B., Viana, H.F., Silva, F.R., Silva-Lobo, V.L., Silva, G.B., Prabhu, A.S., Filippi, M.C.C., 2008. Quantificação da atividade enzimáticas de proteínas relacionadas à patogênese no patossistema Oryza sativa/Magnaporthe oryzae. Embrapa Arroz e Feijão, Santo Antônio de Goiás.

Dean, R., Van, Kan, J.A.L., Pretorius, Z.A., Hammond-Kosack, K.E., Di Pietro, A., Spanu, P.D., Rudd, J.J., Dickman, M., Kahmann, R., Ellis, .J, Foster, G.D., 2012. The Top 10 fungal pathogens in molecular plant pathology. Mol. Plant. Pathol. 13, 414-430.

Dawwam, G.E., Elbeltagy-Emara A.H.M., Abbas, I.H., Hassan, M.M., 2013. Beneficial effect of plant growth promoting bacteria isolated from the roots of potato plant. Ann. Agri. Sci. 58, 195-201.

Filippi, M.C., Prabhu, A.S., 2001. Phenotypic virulence analysis of Pyricularia grisea isolates from Brazilian upland rice cultivars. Pesq. Agropec. Bras. 36, $27-35$.

Filippi, M.C.C., da Silva, G.B., Silva-Lobo, V.L., Côrtes, M.V.C.B., Moraes, A.J.G., Prabhu, A.S., 2011. Leaf blast (Magnaporthe oryzae) suppression and growth promotion by rhizobacteria on aerobic rice in Brazil. Biol. Control 58, 160-166. 
Fisher, M.C., Henk, D.A., Briggs, C.J., Brownstein, J.S., Madoff, L.C., McCraw, S.L., Gurr, S.J., 2012. Emerging fungal threats to animal, plant and ecosystem health. Nature 484, 186-194.

García-Cristobal, J., García-Villaraco, A., Ramos, B., Gutierrez-Mañero, J., Lucas, J.A., 2015. Primming of pathogenesis related-proteins and enzymes related to oxidative stress by plant growth promoting rhizobacteria on rice plants upon abiotic and biotic stress challenge. J. Plant Physiol, 188, 72-79.

Hao, Z.N., Wang, L.P., Tao, R.X., 2009. Expression patterns of defense genes and antioxidant defence responses in a rice variety that is resistant to leaf blast but susceptible to neck blast. Physiol. Mol. Plant P. 74, 167-174.

Jaworski, E.G., 1971. Nitrate reductase assay in intact plant tissues. Biochem. Bioph. Res. 43, 1274-1279.

Jeon, J., Park, S-Y., Chi, M-H., Choi, J., Park, J., Rho, H-S., Kim, S., Goh, J., Yoo, S., Choi, J., Park, J-Y., Yi, M., Yang, S., Kwon, M-J., Han, S-S., Kim, B.R., Khang, C.H., Park, B., Lim, S-E., Jung, K., Kong, S., Karunakaran, M., Oh, H-S., Kim, H., Kim, S., Park, J., Kang, S., Choi, W-B., Kang, S., Lee, Y-H., 2007. Genome-wide functional analysis of pathogenicity genes in the rice blast fungus. Nature Genet. 39, 561-565.

Kado, C.I., Heskett, M.G., 1970. Selective media for isolation of Agrobacterium, Corynebacterium, Erwinia, Pseudomonas and Xanthomonas. Phytopathology 60, 969976.

Keesey, J., 1987. Biochemica Information. Boehringer Manhein Biochemicals, Indianapolis.

Konishi, M., Yanagisawa, S., 2011. The regulatory region controlling the nitrateresponsive expression of a nitrate reductase gene, NIA1, in Arabidopsis. Plant Cell Physiol. 52, 824-36.

Kức J., 1982. Induced immunity to plant disease. Bioscience 32, 54-60.

Lana, A.C., Carvalho, M.A.F., 2013. Nitrato redutase e sua importância no estabelecimento de plantas de arroz de terras altas. Embrapa Arroz e Feijão, Santo Antônio de Goiás.

Larsen, J., Cornejo, P., Barea, J.M., 2009. Interactions between the arbuscular mycorrhizal fungus Glomus intraradices and the plant growth promoting rhizobacteria Paenibacillus polymyxa and P. macerans in the mycorrhizosphere of Cucumis sativus. Soil Biol. Biochem. 41, 286-292.

Lugtenberg, B., Kamilova, F., 2009. Plant-growth-promoting rhizobacteria. Annu. Rev. Microbiol. 63, 541-556. 
Martins, B.E.M, 2015. Caracterização morfológica, bioquímica e molecular de isolados bacterianos antagonistas a Magnaporthe Oryzae. Dissertation, Universidade Federal de Goiás, Brasil. Meher, H.C., Gajbhite, V.T., Singh, G.A., 2012. Liquid chromatography method for determination of selected amino acids, coenzymes, growth regulators, and vitamins from Cicer arietinum (L.) and Solanum lycopersicum (L.). Journal AOAC Int. 95, 11421152.

Minami, E.I., Ozeki, Y., Matsuoka, M., Koizuka, N., Tanaka, Y., 1989. Structure and some characterization of the gene for phenylalanine ammonia-lyase from rice plants. European J. Biochem. 185, 19-25.

Mirik, M., Aysan, Y., Cinar, O., 2008. Biological control of bacterial spot disease of pepper with Bacillus strains. Turk. J. Agri. For. 32, 381-390.

Nascente, A.S., Kluthcouski, J., Rabelo, R.R., Oliveira, P., Cobucci, T., Crusciol, C.A.C., 2011. Produtividade do arroz de terras altas em função do manejo do solo e da época de aplicação de nitrogênio. Pesqui. Agropecu. Trop. 41, 60-65.

Nascimento, F.X., Rossi, M.J., Soares, C.R.F.S., McConkey, B.J., Glick, B.R., 2014. New insights into 1-aminocyclopropane-1-carboxylate (ACC) deaminase phylogeny, evolution and ecological significance. PLoS One 9, 1-17.

Nemie-Feyissa, D., Królicka, A., Forland, N., Hansen, M., Heidari, B., Lillo, C., 2013. Post-translational control of nitrate reductase activity responding to light and photosynthesis evolved already in the early vascular plants. J. Plant Physiol. 170, 662667.

Nishizawa, Y., Saruta, M., Nakazono, K., Nishio, Z., Soma, M., Yoshida, T., Nakajima, E., Hibi, T., 2003. Characterization of transgenic rice plants over-expressing the stressinducible $\beta$-glucanase gene Gns1. Plant Mol. Biol. 51, 143-152.

Notteghem, J.L., 1981. Cooperative experiment on horizontal resistance to rice blast. In: BLAST and upland rice: report and recommendations from the meeting for international collaboration in upland rice improvement. International Rice Research Institute, Los Baños, pp 43-51.

Ou, S.H., 1987. Rice Diseases 2nd edn. CAB International, Farnham House, Farnham Royal, Slough.

Ou, S.H., 1980. Pathogen variability and host resistance in rice blast disease. Annu, Rev. Phytopathol. 18, 167-187.

Pan, S.Q., Ye, X.S., Kuc, J., 1991. Association of a b-1,3-glucanase activity and isoform pattern with systemic resistance to blue mold in tobacco induced by stem injection with Peronospora tabacina or leaf inoculation with tobacco mosaic virus. Physio. Mol. Plant. P. 39, 25-39. 
Prabhu, A.S., Filippi, M.C., Silva, G.B., Lobo, V.L.S., Moraes, O.P., 2009. An unprecedented outbreak of rice blast on a newly released cultivar BRS Colosso in Brazil. In: Wang., G.L., Valente, B. (Eds.), Advances in Genetics, Genomics and Control of Rice Blast Disease. Springer, New York, pp 257-266.

Pieterse, C.M.J., Leon-Reyes, A., Van der Ent, S., Van Wees, S.C.M., 2009. Networking by small-molecule hormones in plant immunity. Nat. Chem. Biol. 5, 308316.

Qin, S., Miao, Q., Feng, W.W., Wang, Y., Zhu, X., Xing, K., Jiang, J.H., 2015. Biodiversity and plant growh promoting traits of culturable endophytic actinobacteria associated with Jatropha curcas L. growing in Panxi dry-hot valley soil. Appl. Soil Ecol. 93, 47-55.

Robert-Seilaniantz, A., Grant, M., Jones, J.D.G., 2011. Hormone crosstalk in plant disease and defense: more than just jasmonate-salicylate antagonism. Annu. Rev. Phytopathol. 49, 317-343.

Saikia, S., Parker, E.J., Koulman, A., Scott, B., 2006. Four gene products are required for the fungal synthesis of the indole-diterpene, paspaline. FEBS Lett. 580, 1625-1630

Spaepen, S., Vanderleyden, J., Okon, Y., 2009. Plant growth-promoting actions of rhizobacteria. Adv. Bot. Res. 51, 283-320.

Son, J.S., Sumayo, M., Hwang, Y.J., Kim, B.S., Ghim, S.Y., 2014. Screening of plant growth-promoting rhizobacteria as elicitor of systemic resistance against gray leaf spot disease in pepper. Appl. Soil Ecol. 72, 1-8.

Talbot, N.J., 2003. On the trail of a cereal killer: investigating the biology of Magnaporthe grisea. Annu. Rev. Microbiol. 57, 177-202.

Thaler, J.S., Humphrey, P.T., Whiteman, N.K., 2012. Evolution of jasmonate and salicylate signal crosstalk. Trends Plant. Sci. 17, 260-270.

Verma, J.P., Yadav, J., Tiwari, K.N., Jaiswal, D.K., 2014. Evaluation of plant growth promoting activities of microbial strains and their effect on growth and yield of chickpea (Cicer arietinum L.) in India. Soil Biol. Biochem. 70, 33-37.

De Vleesschauwer, D., Gheysen, G., Hofte, M., 2013. Hormone defense networking in rice: tales form a different world. Trends Plant Sci. 18, 555-565.

Wang, R., Shen, W.B., Liu, L.L., Jiang, L., Liu, Y.Q., Su, N., Wan, J., 2008. A novel lipoxygenase gene from developing rice seeds confers dual position specificity and responds to wounding and insect attack. Plant Mol. Biol. 66, 401-414.

Wilson, R.A., Talbot, N.J., 2009. Under pressure: investigating the biology of plant infection by Magnaporthe oryzae. Nat. Rev. Microbiol. 7, 185-195. 
739 Zaidi, A., Ahmad, E., Khan, M.S., Saif, S., Rizvi, A., 2015. Role of plant growth 740 promoting rizhobacteria in sustainable production of vegetables: Current perspective.

741 Sci. Hortic. 195, 231-239.

742

743

Zeigler, R.S., Barclay, A., 2008. The relevance of rice. Rice 1, 3-10. 


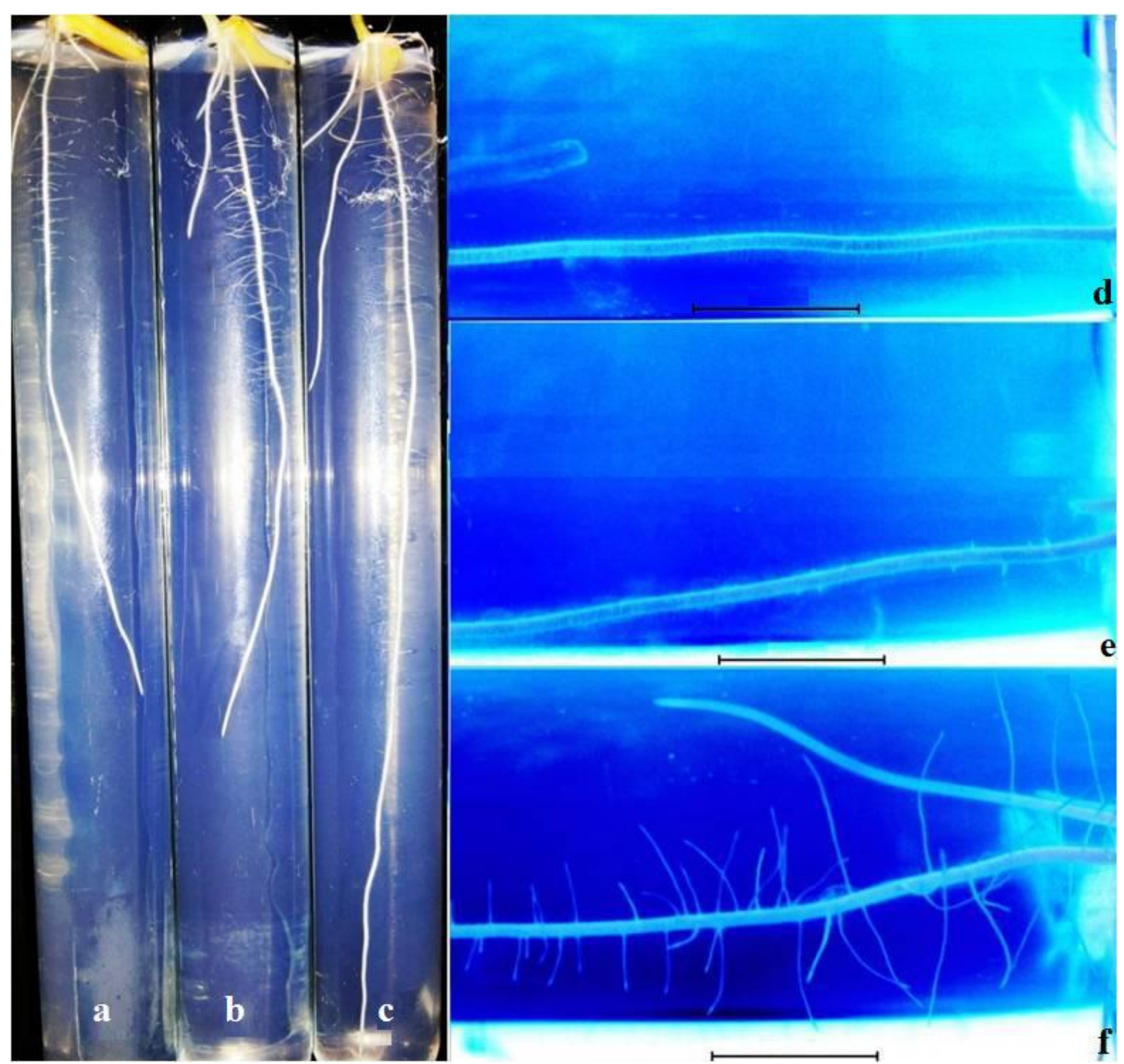

Fig. 1. Root growth of rice seedling 10 days after planting. Seeds were microbiolized with water (A and D), with isolates BRM 32110 (B and E) and BRM 32114 (C and F) and transferred to test tubes containing water-agar medium $(0.8 \% \mathrm{w} / \mathrm{v})(\mathrm{bar}=5 \mathrm{~mm})$.

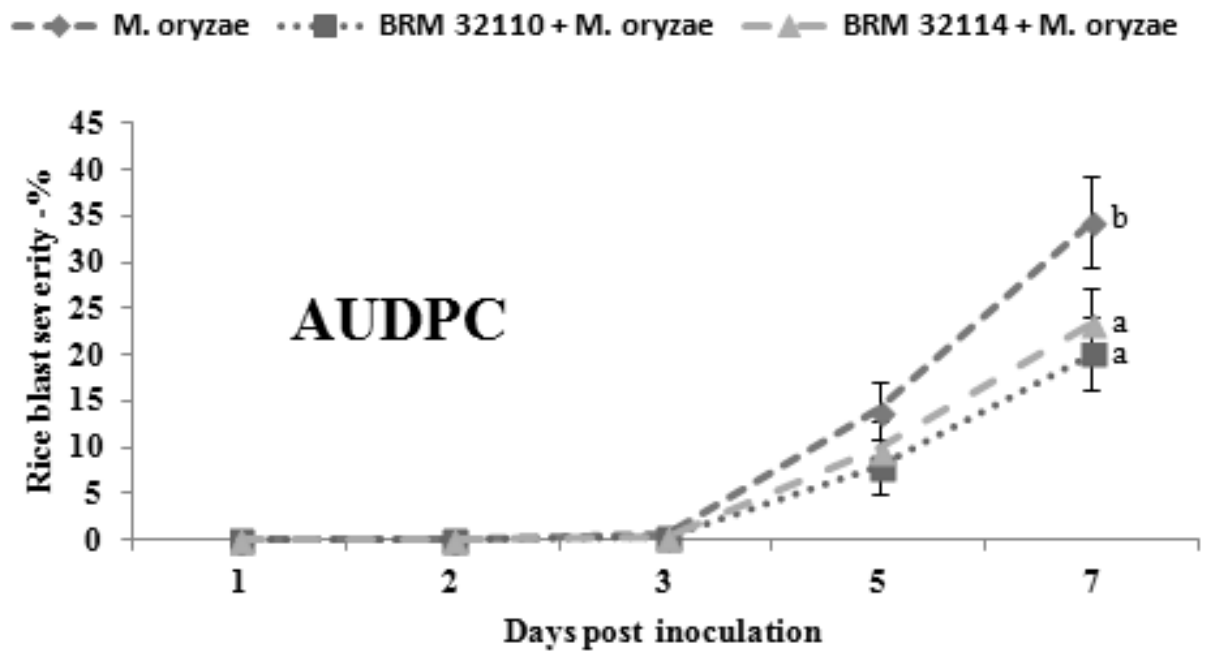


Fig. 2. Area under the disease progress curve (AUDPC) of three different treatments: control (diamond): seeds microbiolized and plants drenched with water only and sprayed inoculated with $M$. oryzae conidial suspension; BRM32110 (square): seeds microbiolized and plants drenched with BRM 32110 suspension and sprayed inoculated with M. oryzae conidial suspension; BRM32114 (triangle): seeds microbiolized and plants drenched with BRM 32114 suspension and sprayed inoculated with $M$. oryzae conidial suspension. The bars above and below show maximum and minimum values of disease severity, respectively. Curves followed by the same letter are not statistically different by Tukey $(p=0,05)$ test.

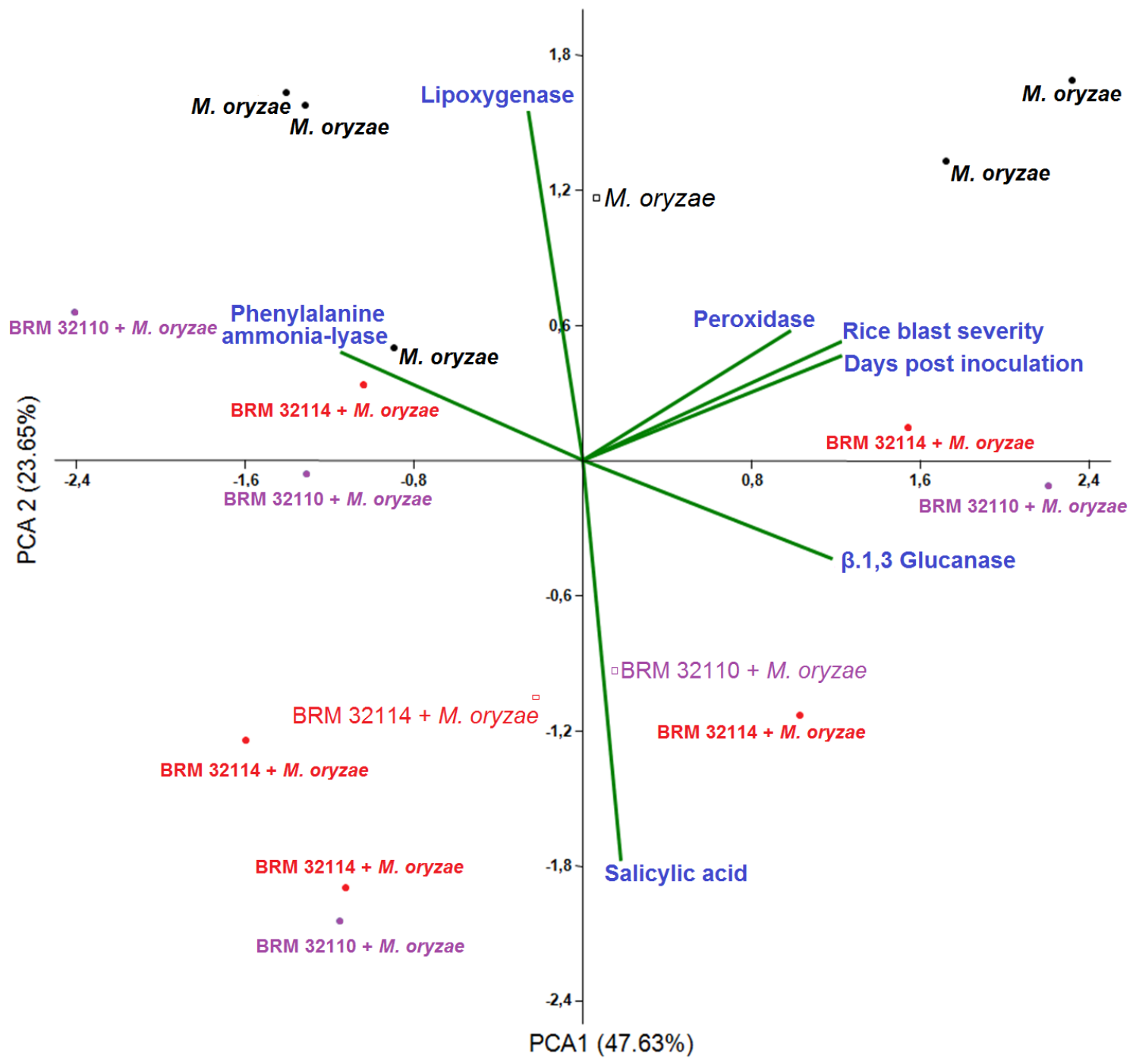

Fig. 3. Principal Component Analyses plot with induced resistance variables investigated for control of rice blast $(M$. oryzae $)$ by plant growth-promoting rhizobacteria. 


\section{CAPÍTULO 2 \\ Magnaporthe oryzae}


Indução de resistência à brusone foliar em arroz por isolados avirulentos de Magnaporthe oryzae.

\section{RESUMO}

A brusone do arroz é uma doença de difícil controle devido à alta variabilidade genética de $M$. oryzae. A resistência raça-específica é associada com reação de hipersensibilidade e pode induzir respostas de defesa da planta contra patógenos virulentos. $\mathrm{O}$ objetivo deste trabalho foi estudar os mecanismos de defesa envolvidos na indução de resistência (IR) e a interação dessas respostas de defesa contra M. oryzae. Quantificou-se a atividade das proteínas relacionadas à patogênese (PRP) conteúdo de compostos fenólicos (CF), teores de SA, além da identificação de modificações histológicas em plantas de arroz induzidas com M. oryzae avirulento (PY10749) e desafiadas com M. oryzae virulento (PY10900). Suspensão de conídios de PY10749 foi pulverizado nas folhas da cultivar de BRS Primavera 48 horas antes do desafio com PY10900. Comparadas a testemunha, a severidade de brusone foliar (SBF) foi menor nas plantas induzidas, que apresentaram lesões típicas de reação de hipersensibilidade. As atividades de $\beta$-1,3-glucanase (GLU), fenil alanina-amônio liase (PAL) e peroxidase (POX) foram maiores nas plantas induzidas nas primeiras horas após o desafio com PY10900, bem como a quantidade de CF e teor de SA. As variáveis de PRPs bem como CF, SA, dias após a indução (DPI) e SBF foram submetidas uma análise multivariada. A análise de componentes principais (PCA) revelou que GLU, PAL, SA e DPI foram a principal fonte de variância observada no primeiro componente; SBF, POX e PAL no segundo e SBF e CF no terceiro. Esses resultados sugerem que, em interações incompatíveis entre Oryza sativa-M. oryzae, a atividade GLU é alta nos primeiros dias, decrescendo com o passar o tempo e que os níveis de SA e PAL alternam entre si. SBF foi menor nas plantas com maior atividade de POX e indicam que essa PRP possui papel-chave no desenvolvimento de lesões do tipo RH. As análises de microscopia revelaram que as plantas induzidas responderam de forma rápida ao desafio de $M$. oryzae virulento. Apesar de seus conídios germinarem e formarem apressório, não houve penetração e colonização dos tecidos foliares.

Palavras-chave: Interação incompatível, Oryza sativa, reação de hipersensibilidade, resistência sistêmica adquirida. 
Induction of resistance in rice against leaf blast resistance by avirulent isolate of Magnaporthe oryzae.

\section{ABSTRACT}

Rice blast is a disease of difficult control due to the high genetic variability of the pathogen. Race-specific resistance is associated with sensitivity reaction and may induce plant defense responses against virulent pathogens. The goal of this work was to study the defense mechanisms involved in the induction of resistance (IR) through the quantification of pathogenesis proteins related (PRP), phenolic compounds content (CF), level of salicylic acid (SA) and to observe modifications at the cellular level in plants iniduced by avirulent M. oryzae (PY10749) and challenged with virulent isolate (PY10900). Suspension of PY10749 conidia was sprayed on the BRS Primavera rice cultivar 48 hours prior to challenge with PY10900. Compared to the control, the leaf blast severity (SBF) was lower in the induced plants, which presented lesions typical of the hypersensitivity reaction. $\beta-1,3-$ Glucanase (GLU), phenylalanine ammonium-lyase (PAL) and peroxidase (POX) activities were higher in the plants induced during the first hours after challenge with PY10900, as well as the amount of CF and SA content. The variables of PRPs as well as CF, SA, days after induction (DPI) and SBF were submitted to a multivariate analysis. Principal component analysis (PCA) revealed that GLU, PAL, SA and DPI were the main source of variance observed in the first component; SBF, POX and PAL in the second and SBF and CF in the third. These results suggest that in incompatible interactions between Oryza sativa-M. Oryzae, GLU activity is high in the early days, decreasing over time, and that SA and PAL levels alternate with each other. SBF was lower in plants with higher POX activity and indicate that this PRP has a key role in HR mediated by PY10749. Microscopy analysis revealed that the induced plants responded rapidly to the challenge of virulent $M$. oryzae. Although its conidia germinated and formed appressoria, there was no penetration and colonization of the foliar tissues.

Key words: Incompatible reaction, hypersensitivity reaction, Oryza sativa, systemic acquired resistance. 


\section{INTRODUÇÃO}

Uma característica do sistema imune em eucariotos é a habilidade de reconhecer patógenos invasores e mobilizar apropriadamente as respostas de defesas. As plantas são capazes de defenderem-se de uma ampla gama de patógenos por meio de mecanismos sofisticados de reconhecimento e sinalização (Spoel \& Dong, 2012). Durante a interação planta-patógeno, a primeira linha de defesa da planta é seu sistema de reconhecimento de padrões moleculares associados a patógenos (PAMP) e a microrganismos (MAMP) que confere resistência basal por meio da imunidade ativada por PAMP (PTI) (Faulkner \& Robatzek, 2012). Se o sistema de reconhecimento dos MAMPs falharem contra microrganismos patogênicos, a segunda linha de defesa é induzida (PTI). Esta é uma resistência específica entre a cultivar da hospedeira e a raça do patógeno, entretanto, com o aparecimento de novas raças do patógeno esse tipo de resistência pode ser quebrada (Dang et al., 2012) o que acontece com frequência com Magnaporthe oyzae, fungo causador da brusone do arroz (Dean et al., 2012). A imunidade ativada por efetores (ETI) é um tipo de resistência a doenças que as plantas ativam quando seus genes de resistência $(\mathrm{R})$ reconhecem, direta ou indiretamente, um produto específico de genes do patógeno, também chamado de efetor, codificado por gene(s) de avirulência (Avr) (Kunstler et al., 2016). Tanto em PTI quanto em ETI, o resultado do reconhecimento do patógeno é ativação de respostas de defesas que podem desencadear entre outros mecanismos, reação de hipersensibilidade (HR), que é uma forma de morte celular programada que restringe o patógeno no sítio de infecção, o que leva ao aparecimento de pontoações castanhas visíveis a olho nú (Tsuda \& Katagiri, 2010).

Como resultado do reconhecimento dos patógenos pelas plantas, a HR desencadeia em cascata uma série de respostas de defesa. Ela induz sinais celulares e bioquímicos, que ativa outras respostas de defesa que incluem fluxos de íons, indução de cascata de sinais de proteínas quinases, explosão oxidativa, aumento de hormônios elicitores como ácido jasmônico, estimulam metabolismo secundário com a produção de compostos fenólicos e fitoalexinas e aumentam a expressão de genes relacionados a patogênese, que estão envolvidos na produção de proteínas relacionadas a patogênese (Daymi et al., 2016; Kunstler et al., 2016). Essa sequência de modificações, juntamente com respostas estruturais de defesa como deposição de lignina, formação de papilas e deposição de calose, estão relacionadas com a restrição do patógeno ao sítio de 
penetração, impedindo a colonização das células e tecidos da planta pelo patógeno por meio da formação de barreias mecânicas ao crescimento do fungo.

A brusone do arroz é uma das doenças mais graves do mundo, sendo de difícil controle, reduzindo a produção anual de arroz entre 10 e 30\% (Strange \& Scott, 2005). Vários genes de resistência a M. oryzae foram identificados (Monaco et al., 2013) e muitos deles foram clonados, entretanto, a maioria dos genes $\mathrm{R}$ conferem resistência à um ou poucos isolados devido a sua especificidade com a raça do patógeno, não protegendo a planta contra outras raças deste fungo. Tanto nos casos de compatibilidade como de incompatibilidade, a expressão de respostas de defesa depende da eficiência do reconhecimento do patógeno pelo hospedeiro (Filippi et al., 2007). Investigar a interação entre $M$. oryzae-Oryza sativa, bem como a interação entre as respostas de defesa da planta são pontos fundamentais para identificar medidas alternativas para o controle da brusone.

Neste sentido, o uso de isolados avirulento para induzir respostas de defesa pode ser uma ferramenta importante para entender os mecanismos envolvidos na indução de resistência e representa uma estratégia inteligente na busca de novas fontes de resistência a brusone, assim conferindo uma ampla resistência contra não só outros isolados de M. oryzae, mas também contra outros patógenos do arroz.

O objetivo deste trabalho foi estudar o processo de indução de resistência em plantas de arroz utilizando isolados avirulentos de $M$. oryzae, observando as respostas de defesa bioquímicas e em nível histológico pelas plantas de arroz. 


\section{MATERIAL E MÉTODOS}

\subsection{Seleção de isolados de Magnaporthe oryzae}

Vinte e três isolados de $M$. oryzae foram utilizados para teste de virulência, foram eles: 4145, 4285, 4287, 4327, 4330, 4355, 4377, 4378, 4382, 4389, 4466, 4651, 10723, 10731, 10749, 10771, 10786, 10885, 10893, e 10900. Esses isolados pertencem a Coleção de Microrganismos Multifuncionais da Embrapa Arroz e Feijão e foram obtidos de monospóricos feitos a partir de lesões esporulativas de folhas. A virulência dos isolados foi testada utilizando dezesseis cultivares diferenciadoras, oito cultivares comerciais nacionais de arroz de terras altas (Carajás, Confiança, Maravilha, Primavera, Progresso, Caiapó, IAC 47 e IAC 201) e oito cultivares internacionais (Raminad, Zenith, NP 125, Usen, Dular, Kanto S1, STT e Caloro). Sementes de cada cultivar foram plantadas em linhas em bandejas de plástico $(30 \times 15 \times 10 \mathrm{~cm})$ contendo $3 \mathrm{Kg}$ de solo adubado (FTE 1g/ kg solo, Zn $1 \mathrm{~g} / 2 \mathrm{~kg}$ e NPK - 5/30/15g/kg), e mantidas em condições de $60 \%$ de umidade e temperatura de média de $25{ }^{\circ} \mathrm{C}$ em casa de vegetação. Foram semeadas em média 10 sementes por cultivar. Os isolados de M. oryzae foram reativados em meio BDA e multiplicado em placas de Petri contendo meio de Aveia (50g de aveia, $10 \mathrm{~g}$ dextrose, $15 \mathrm{~g}$ ágar, $1 \mathrm{~L}$ água), durante 10 dias a $28{ }^{\circ} \mathrm{C}$. A conidiogenese foi estimulada com a remoção do micélio aéreo, feito com o auxílio de um bastão de vidro, e as placas expostas a luz contínua, sob alta umidade, durante 48 horas. Os conídios foram coletados com água destilada e esterilizada, a suspensão foi ajustada a $3 \times 10^{5}$ conídios. $\mathrm{mL}^{-1}$ seguindo o método de Filippi \& Prabhu, 2001, e pulverizada nas folhas em plantas, 21 dias após a semeadura. Uma bandeja com as mesmas cultivares inoculadas com água foi utilizada como controle e/ou detecção de contaminação. A severidade de brusone foliar foi avaliada sete dias após a inoculação desafiadora utilizando uma escala que varia de 0 a 9 do International Rice Research Institute (1988) que leva em consideração o tipo de lesão, onde plantas com lesões de 0 , 1 e 3 são consideradas resistente (reação incompatível) e 4 a 9 como suscetível (compatível).

\subsection{Plantio cultivar BRS Primavera}

Sementes de arroz BRS Primavera foram esterilizadas com soluções de álcool $70 \%$ e hipoclorito de sódio e plantadas em bandejas com $3 \mathrm{~kg}$ de solo adubado (FTE 1g/ 
kg solo, Zn 1g/2 kg e NPK - 5/30/15g/kg), e mantidas em condições de $60 \%$ de umidade e temperatura média de $25^{\circ} \mathrm{C}$ em casa de vegetação. Cada bandeja possui oito sulcos, com 10 plantas em cada.

\subsection{Indução de resistência usando isolado avirulento de $M$. oryzae}

O Isolado avirulento de $M$. oryzae proveniente da coleção de microrganismos da Embrapa Arroz e Feijão foi selecionado com base nos critérios descritos no tópico anterior. Ele foi reativado em meio BDA (Batata-dextrose-ágar) e multiplicado em placas de Petri com meio de aveia (aveia 2\%, 1,5\% ágar, p/v), durante 10 dias a $28{ }^{\circ} \mathrm{C}$. A produção de conídios foi estimulada com a remoção do micélio aéreo da colônia de M. oryzae. Os conídios foram coletados com água destilada e esterilizada e 48 após, a suspensão será ajustada a $3 \times 10^{5}$ conídios. $\mathrm{mL}^{-1}$ (Filippi \& Prabhu, 2001) e inoculadas na cultivar de arroz Primavera 19 dias após a semeadura. A porcentagem de área foliar afetada pela brusone foi quantificada usando uma escala de notas (0-82\% de área foliar afetada) de acordo com Notteghem (1981). As plantas foram avaliadas durante uma semana após a inoculação de $M$. oryzae em condições de casa de vegetação.

\subsection{Desafio com M. oryzae}

O isolado virulento PY10900 de M. oryzae proveniente da coleção de microrganismos da Embrapa Arroz e Feijão foi cultivado nas mesmas condições de crescimento que o isolado avirulento, bem como os ajustes de concentração. A suspensão de conídios foi inoculada em cultivares primavera com 21 dias após o plantio. As plantas foram marcadas para obter-se a área abaixo da curva de progresso da doença (AUDPC - area under the disease progress curve) e a porcentagem de área foliar afetada pela brusone foi medida usando uma escala de notas $(0,5$ a $82 \%$ de área foliar afetada) de acordo com Notteghem (1981). As plantas foram avaliadas no $1^{\circ}, 2^{\circ}$, $3^{\circ}, 5^{\circ}$ e $7^{\circ}$ dia após a inoculação de $M$. oryzae em condições de casa de vegetação.

\subsection{Desenho experimental}

O delineamento realizado foi de blocos ao acaso (DBC). Os tratamentos foram: testemunha $M$. oryzae avirulento (AVR), testemunha - $M$. oryzae virulento (VIR); plantas induzidas com isolado AVR e desafiadas com VIR (AVR + VIR) e controle negativo $\left(\mathrm{H}_{2} \mathrm{O}\right)$. Foram utilizadas três bandejas por tratamento. 


\subsection{Determinação da atividade das enzimas $\beta-1,3$ glucanase, peroxidase,}

fenilalanina amônia-liase, quantificação de compostos fenólicos e ácido salicílico em plantas de arroz

A fim de detectar propriamente o estado de priming nas plantas, os valores das variáveis em questão foram checados também nos seus respectivos controles (plantas não-desafiadas com isolado virulento PY10900) tendo assim valores da atividade das respectivas enzimas, tanto em plantas induzidas, induzidas e desafiadas e plantas não induzidas e não desafiadas $\left(\mathrm{H}_{2} \mathrm{O}\right)$, para comparações e detecção de atividades significativamente superior. Plantas tratadas apenas com M. oryzae foram utilizadas como testemunhas e plantas tratadas com $\mathrm{H}_{2} \mathrm{O}$ como controle negativo. As coletas foram feitas em 1, 2, 3, 5, 7 e 9 DPI. Toda parte aérea da planta foi coletada, dez plantas por tratamento, e então acondicionadas em caixas de gelo e congeladas $\left(-20{ }^{\circ} \mathrm{C}\right)$ para uso posterior.

\section{Extração de proteínas}

As amostras da parte aérea das plantas de arroz foram maceradas em nitrogênio líquido e em cada amostra foi adicionado solução-tampão (Tris- $\mathrm{HCl} 10 \mathrm{mM} ; \mathrm{NaCl}$ [150 $\mathrm{mM}$ ]; EDTA [2 mM]; DTT [2 mM]; PMFS [1 mM]; Leptina [10 $\mu \mathrm{g} \cdot \mathrm{mL}^{-1}$ ]; Aprotinina $\left.\left[10 \mu \mathrm{g} \cdot \mathrm{mL}^{-1}\right]\right)$. Em seguida, as amostras foram agitadas num vortex durante 1 minuto e centrifugadas por 5 minutos a $10.000 \mathrm{rpm}$ a $4^{\circ} \mathrm{C}$. O sobrenadante foi utilizado para quantificar as proteínas solúveis totais e nos ensaios de determinação de atividade enzimática. Cinquenta $\mu \mathrm{L}$ de cada amostra foram transferidos para tubos do tipo Eppendorf acrescentando $1000 \mu \mathrm{L}$ de CBB (comoassie brilliant blue). As amostras foram homogeneizadas e colocadas em repouso durante 15 minutos. Após, transferiu-se $100 \mu \mathrm{L}$ para placas de Elisa as quais foram colocadas em espectrofotômetro ( $\lambda 597 \mathrm{~nm})$. O conteúdo de proteínas solúveis totais no extrato bruto foi medido de acordo com o método de Bradford (1976), com albumina sérica bovina (BSA) como padrão.

\section{$\beta$-1,3-Glucanase (EC 3.2.1.39) (GLU)}

Utilizou-se a metodologia descrita por Pan et al., (1991) com algumas modificações. Atividade de GLU em extrato proteico de folhas de arroz de diferentes tratamentos foram avaliados pela medição da taxa de redução de açúcar utilizando laminarina como substrato. O reagente DNS (ácido dinitrosalicílico) foi usado como 
agente colorimétrico. A atividade foi expressa em unidades por miligrama de proteína $\left(\mathrm{U}_{\mathrm{mg}} \mathrm{g}^{-1}\right)$. Uma unidade de atividade enzimática foi definida como atividade enzimática catalisando a formação de açúcares redutores que aumenta a absorbância de uma unidade por hora.

\section{Peroxidase (EC 1.11.1.7) (POX)}

A atividade de peroxidase foi quantificada por meio da medição do nível de oxidação de 2,2'-azino-bis-(3-etilbenzotiazolina-6-ácido sulfônico) usando suas próprias atividades colorimétricas, onde a coloração fica mais intensa a medica que a reação acontece. Uma unidade foi definida como atividade enzimática catalisando a formação de 2,2'-azino-bis-(3-etilbenzotiazolina-6-ácido sulfônico) que aumenta a absorbância de uma unidade por hora (Keesey, 1987).

\section{Fenilalanina Amônia-liase (EC 4.3.1.24) (PAL)}

A atividade de fenilalanina amônia-liase foi determinada, utilizando $2 \mathrm{ml}$ de solução de fenilalanina $10 \mathrm{mM}$, em solução tampão borato $0,1 \mathrm{M}, \mathrm{pH}$ 9,0 e $50 \mu \mathrm{lde}$ cada amostra, em triplicata. A mistura foi homogeneizada e submetida à quantificação em espectrofotômetro, em comprimento de onda $290 \mathrm{~nm}$ (ultravioleta) (Côrtes et al., 2008).

\section{Compostos Fenólicos (CF)}

A quantificação de compostos fenólicos totais foi realizada segundo a metodologia de Dicko et al. (2002).A parte aérea das plantas de arroz foram coletadas para quantificação dos compostos fenólicos. O material foi imediatamente congelado em nitrogênio líquido após a coleta. As plantas foram maceradas com auxílio de cadinhos e pistilos até a obterção de um pó fino e homogêneo. Trezentos microlitros dos compostos fenólicos solúveis foram colocados em $1500 \mu \mathrm{L}$ de metanol $70 \%$ e, após levá-las ao sonicador por 30 minutos, as amostras foram filtradas com auxílio de algodão. O ensaio foi feito em triplicata por cada amostra onde $120 \mu \mathrm{L}$ do extrato foi misturado com $220 \mu \mathrm{L}$ de $\mathrm{H}_{2} \mathrm{O}$ milli-Q e $200 \mu \mathrm{L}$ de Folin-Ciocalteu. Após 5 min de incubação foi adicionado solução de $\mathrm{Na}_{2} \mathrm{CO}_{3}$ a $20 \%$ e $600 \mu \mathrm{L}$ de $\mathrm{H}_{2} \mathrm{O}$ milli-Q. A mistura foi incubada por $30 \mathrm{~min}$ a temperatura ambiente e a leitura foi feita em espectrofotômetro numa absorbância de $720 \mathrm{~nm}$. 


\section{Ácido Salicílico (SA)}

Para quantificação de AS nas plantas de arroz, 200 mg da parte aérea de cada tratamento foram maceradas e transferidas para microtubos $(2 \mathrm{~mL})$. Em cada microtubo foi adicionado $1 \mathrm{~mL}$ de metanol (90\%), seguido de agitação em agitador, por 1 minuto. As amostras foram centrifugadas, a $5000 \mathrm{rpm}$ por 10 minutos, e transferidas para um tubo falcon, de $15 \mathrm{~mL}$. Adicionou-se em cada tubo, $1 \mathrm{~mL}$ de metanol PA e $2 \mathrm{~mL}$ de ácido tricloroacético (5\%), e $2 \mathrm{~mL}$ de acetato de etila, ciclopentano e isopropanol (50:50:1). As amostras foram agitadas em agitador por 1 minuto, e o sobrenadante foi transferido para outro tubo para liofilização. Em seguida, foi adicionado em cada tubo $200 \mu \mathrm{L}$ de metanol (23\%), em tampão acetato $(20 \mu \mathrm{mol} \mathrm{pH} 5,0)$, que foram filtradas em minifiltro milipore $(0,45 \mu \mathrm{m})$. A quantificação de ácido salicílico foi realizada em um aparelho de cromatografia líquida HPLC (High Performance Liquid Chromatography) apresentando tempo de retenção de 4,8 minutos (Saikia et al., 2006; Meher et al., 2012).

\subsection{Microscopia das folhas de arroz tratadas com isolado avirulento de $M$.} oryzae

Observação de estruturas de penetração via microscopia eletrônica de varredura $(M E V)$

As folhas de arroz foram coletadas no primeiro e segundo dia após o desafio

com o patógeno virulento (3 e 4DPI, respectivamente). Fragmentos de aproximadamente 1 centímetro das folhas foram utilizados para MEV. Esses fragmentos foram fixados em glutamina 2,5\% (p/v) por 24 horas. Após, as amostras foram lavadas em tampão fosfato $0,05 \mathrm{M}$ e submetidas a desidratação etanólica seriada de $30 \%, 40 \%$, $50 \%, 60 \%$ e $70 \%$ durante cinco minutos cada série. A secagem das amostras foi feita na condição de ponto crítico com $\mathrm{CO}_{2}$. Os fragmentos foram colocados em stubs para metalização, sendo cobertas com ouro para posterior análise em microscópio eletrônico de varredura.

\section{Microscopia de luz de estruturas fúngicas de colonização}

A colonização a nível anatômico foi observado por meio de microscopia de luz. Folhas de arroz inoculadas com isolados avirulento de M. oryzae PY10749 foram coletadas no quinto dia após a inoculação desafiadora com o isolado virulento PY 10900. Para a caracterização anatômica das folhas de arroz, foram realizadas secções transversais nas folhas à mão livre com auxílio de lâmina de aço e suporte de isopor. 
Em seguida os fragmentos foram imersos em azul de astra 0,3\% e fucsina básica $0,1 \%$ (3:1) (KRAUS et al., 1998). As secções foram montadas entre lâmina e lamínula com solução de glicerina hidratada a $50 \%$. Os resultados foram analisados e documentados em microscópico óptico (Leica ${ }^{\circledR}$ DM500) acoplado à câmera fotográfica Leica ${ }^{\circledR}$ ICC50, usando a versão 1.8.1 do software LAD EZ (Leica ${ }^{\circledR}$ Alemanha).

\subsection{Análise estatística}

\section{Análise univariada}

Os dados SBF, GLU, PAL, POX, CF e AS foram avaliados utilizando uma análise de variância (ANOVA) e as médias foram comparadas pelo teste de Tukey $(p=0.05)$.

\section{Análise multivariada}

Análise de componentes principais (PCA) reuniu as variáveis relacionadas com as respostas de defesa da planta e severidade de doença. A PCA foi realizada utilizando os pacotes Rcmdr e FactoMineR, ambos do software 'R' 2.15 (R Development Core Team, Vienna, Austria). Essa análise foi feita utilizando tanto os efeitos multivariados das variáveis de indução de resistência (PAL, GLU, PO, AS) quanto as variáveis de doença (severidade e DPI). 


\section{RESULTADOS}

\subsection{Quantificação de doença}

\subsubsection{Seleção de isolados de $M$. oryzae}

Os isolados de M. oryzae PY10749 e PY10900, foram os isolados avirulentos e virulentos selecionados para os ensaios realizados neste trabalho, respectivamente. $\mathrm{O}$ isolados de $M$. oryzae PY10749 foi escolhido pelo fato de desencadear lesões nas plantas do tipo RH e o isolado PY10900 por causar lesões grandes e esporulativas. Além desses resultados, ambos isolados apresentam boa esporulação e rápido crescimento em meio de aveia (dados não mostrados).

TABELA 1- Reação de cultivares a inoculação com diferentes isolados de M. oryzae. Os números são referentes ao tipo de lesão.

\begin{tabular}{|c|c|c|c|c|c|c|c|c|c|c|c|c|c|c|c|c|}
\hline & \multicolumn{16}{|c|}{ Cultivar } \\
\hline $\begin{array}{c}\text { Isolado } M \text {. } \\
\text { oryzae }\end{array}$ & : & 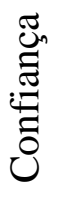 & 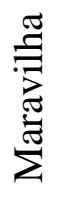 & 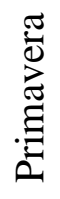 & 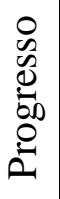 & Ů & 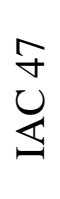 & 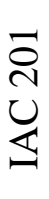 & 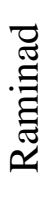 & 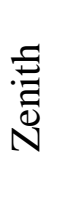 & $\frac{\mathfrak{c}}{\frac{a}{z}}$ & $\begin{array}{l}\mathscr{D} \\
\mathscr{\infty} \\
ٍ\end{array}$ & $\frac{\overline{\vec{t}}}{\bar{\Xi}}$ & 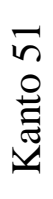 & $\bar{v}$ & $\frac{O}{0}$ \\
\hline 4145 & 0 & 0 & 0 & 3 & 1 & 0 & 0 & 0 & 1 & 0 & 3 & 5 & 0 & 5 & 9 & 9 \\
\hline 4285 & 0 & 1 & 1 & 5 & 1 & 0 & 1 & 0 & 0 & 1 & 5 & 5 & 5 & 9 & 9 & 5 \\
\hline 4287 & 0 & 0 & 0 & 5 & 0 & 0 & 1 & 0 & 0 & 0 & 7 & 5 & 3 & 5 & 9 & 7 \\
\hline 4327 & 3 & 1 & 0 & 5 & 0 & 0 & 0 & 0 & 0 & 0 & 5 & 5 & 3 & 7 & 7 & 7 \\
\hline 4330 & 0 & 0 & 0 & 7 & 0 & 0 & 0 & 0 & 1 & 0 & 3 & 5 & 3 & 7 & 9 & 7 \\
\hline 4355 & 0 & 0 & 0 & 7 & 0 & 0 & 5 & 1 & 0 & 0 & 5 & 5 & 3 & 7 & 9 & 9 \\
\hline 4377 & 0 & 0 & 1 & 5 & 0 & 0 & 0 & 0 & 0 & 0 & 3 & 5 & 1 & 5 & 7 & 7 \\
\hline 4378 & 0 & 0 & 0 & 5 & 0 & 0 & 0 & 0 & 0 & 0 & 1 & 0 & 0 & 0 & 9 & 9 \\
\hline 4382 & 0 & 1 & 0 & 5 & 0 & 0 & 0 & 0 & 0 & 0 & 3 & 3 & 0 & 5 & 7 & 7 \\
\hline 4389 & 0 & 0 & 0 & 5 & 0 & 0 & 0 & 0 & 0 & 0 & 5 & 3 & 1 & 7 & 9 & 9 \\
\hline 4466 & 0 & 0 & 0 & 5 & 0 & 0 & 1 & 3 & 1 & 3 & 3 & 5 & 1 & 7 & 9 & 5 \\
\hline 4651 & 0 & 0 & 0 & 0 & 0 & 0 & 0 & 0 & 0 & 0 & 1 & 0 & 0 & 3 & 5 & 5 \\
\hline 10723 & 1 & 1 & 1 & 1 & 0 & 3 & 7 & 5 & 0 & 1 & 0 & 9 & 3 & 1 & 7 & 9 \\
\hline 10731 & 1 & 1 & 0 & 0 & 0 & 1 & 5 & 5 & 1 & 1 & 5 & 9 & 3 & 0 & 5 & 9 \\
\hline 10749 & 3 & 3 & 1 & 1 & 1 & 0 & 5 & 5 & 1 & 5 & 5 & 9 & 1 & 0 & 5 & 9 \\
\hline 10771 & 0 & 0 & 0 & 5 & 1 & 3 & 3 & 1 & 0 & 1 & 3 & 1 & 5 & 5 & 3 & 7 \\
\hline 10786 & 3 & 5 & 5 & 5 & 7 & 1 & 3 & 1 & 0 & 5 & 5 & 9 & 9 & 9 & 9 & 9 \\
\hline 10885 & 0 & 1 & 0 & 1 & 5 & 0 & 1 & 1 & 0 & 3 & 1 & 7 & 0 & 0 & 3 & 0 \\
\hline 10893 & 0 & 0 & 0 & 1 & 1 & 0 & 0 & 0 & 0 & 0 & 5 & 5 & 0 & 0 & 5 & 0 \\
\hline 10900 & 3 & 5 & 5 & 7 & 7 & 1 & 3 & 1 & 0 & 5 & 5 & 9 & 9 & 9 & 9 & 9 \\
\hline
\end{tabular}

Plantas com 0, 1 e 3 são consideradas resistente (reação incompatível) e 4 a 9 como suscetível. 


\subsubsection{Indução de resistência e supressão de brusone foliar}

Dentre os isolados $M$. oryzae utilizados nos testes para selecionar indivíduos avirulentos e virulentos por meio das cultivares diferenciadoras, foi escolhido o isolado de M. oryzae PY10749 como agente indutor, visto que apresentou reação incompatível com a cultivar BRS Primavera, portanto avirulento, e o isolado PY10900 como M. oryzae virulento. Nas plantas de arroz suscetíveis à brusone induzidas com isolado avirulento de $M$. oryzae, os sintomas típicos apareceram entre 48 e 72 horas após a indução (dados não mostrados), com lesões de reação de hipersensibilidade (Figura 1A e1B). As lesões nas plantas induzidas com o isolado avirulento PY10749 e desafiado com PY10900 (1C) foram semelhantes àquelas encontradas nas plantas quando somente induzidas, não havendo diferenças estatísticas entre estes tratamentos e, quando comparadas com a testemunha, a redução foi maior que 90\%. Já nas testemunhas, onde o tratamento foi apenas o desafio com o patógeno virulento (PY10900), a infecção progrediu e as lesões típicas da doença (Figura 1D) atingiu 30\% da área foliar afetada (Tabela 1).

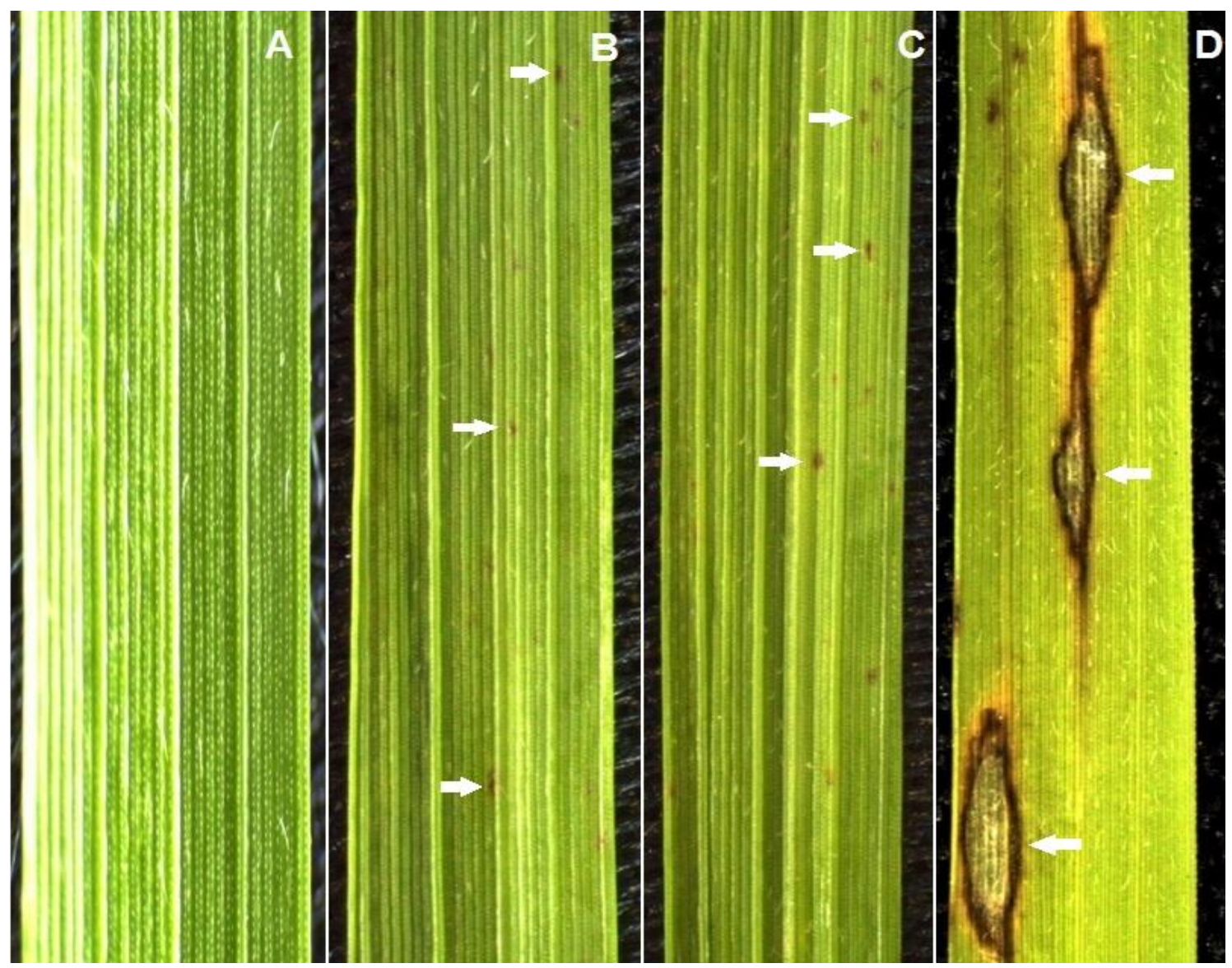

FIGURA 1- Severidade de brusone foliar em folhas de arroz. Plantas controle (A), induzidas com PY10749 (B), induzidas com PY10749 e desafiadas com PY10900 (C) e testemunha PY10900 (D). Setas indicam sintomas de RH em B e C e lesões desenvolvidas e esporulativas em D. 
3.2. Atividades das enzimas relacionadas com a defesa da planta, e quantificação dos compostos fenólicos e teores de ácido salicilico

\section{Plantas tratadas apenas com o isolado avirulento de $M$. oryzae}

A atividade de GLU em plantas induzidas foi maior em todos os dias avaliados quando comparados com o controle $\left(\mathrm{H}_{2} \mathrm{O}\right)$, exceto no 4 DPI (Tabela 2). Quando comparada com o controle, a atividade de PAL em plantas induzidas foi maior apenas no 4DPI e mostrou um aumento nos dois primeiros dias avaliados, entretanto decresceu no 3 DPI, oscilando nos outros tempos amostrados. A atividade de POX apresentou um aumento nas primeiras 48hs após a indução, com os maiores valores nas plantas induzidas com o isolado avirulento no 2DPI. A concentração de compostos fenólicos (CF) decresceram no controle e permaneceu constante nas plantas induzidas, aumentando apenas no 4DPI e 9DPI. Os teores de SA foram maiores nas plantas induzidas nos dois primeiros dias avaliados apresentando um aumento constante até o 3DPI, oscilando nos dias seguintes. A concentração de SA também aumentou do 1 ao 3DPI no controle, reduzindo sua concentração de forma significativa nos dias subsequentes. 
Tabela 2. Atividade de proteínas relacionadas à patogênese $\beta-1,3$ glucanase (GLU), fenilalanina amônia-liase (PAL), peroxidase (POX). e concentração de compostos fenólicos (CF), teor de ácido salicílico (SA) e severidade de brusone foliar em plantas de arroz de terras altas tratadas com os isolado avirulento seguidas ou não de inoculação desafiante com isolado de M. oryzae PY10900 virulento.

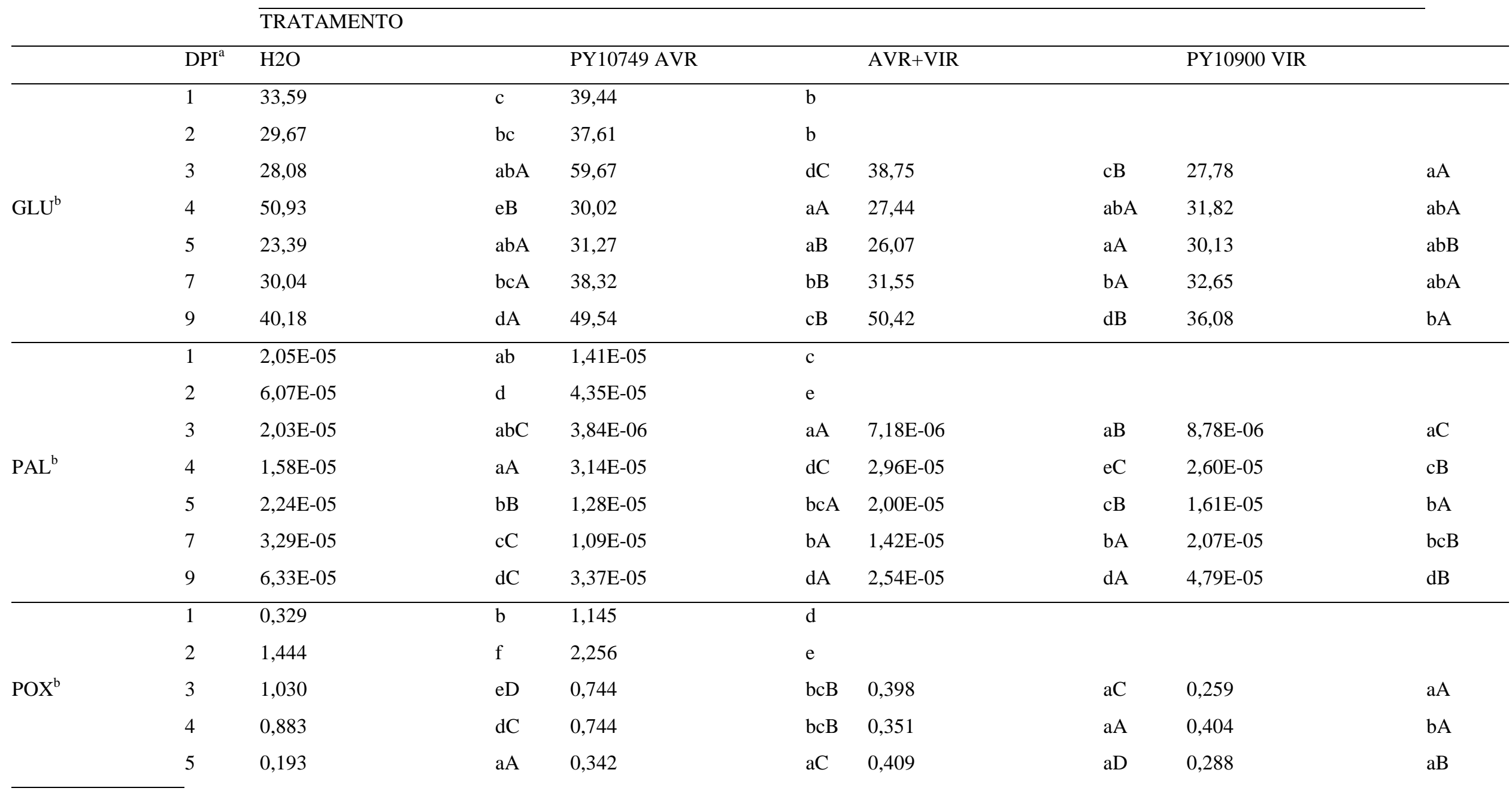




\begin{tabular}{|c|c|c|c|c|c|c|c|c|c|}
\hline & 7 & 0,350 & bA & 0,530 & $\mathrm{abB}$ & 0,368 & $\mathrm{aA}$ & 0,309 & $\mathrm{aA}$ \\
\hline & 9 & 0,701 & $\mathrm{cB}$ & 1,080 & $\mathrm{cdC}$ & 0,678 & bB & 0,382 & $\mathrm{bA}$ \\
\hline \multirow{7}{*}{$\mathrm{CF}^{\mathrm{c}}$} & 1 & 10,59 & $\mathrm{~cd}$ & 8,04 & $\mathrm{a}$ & & & & \\
\hline & 2 & 7,21 & $a b$ & 8,99 & $\mathrm{ab}$ & & & & \\
\hline & 3 & 4,84 & $\mathrm{aA}$ & 9,33 & $\mathrm{abB}$ & 9,07 & bB & 8,44 & $\mathrm{aB}$ \\
\hline & 4 & 7,31 & $\mathrm{abA}$ & 11,31 & $\mathrm{bB}$ & 5,91 & $\mathrm{aA}$ & 10,08 & bB \\
\hline & 5 & 9,00 & $\mathrm{cB}$ & 7,00 & $\mathrm{aA}$ & 6,57 & $\mathrm{aA}$ & 7,51 & $\mathrm{aA}$ \\
\hline & 7 & 9,96 & $\mathrm{cdBC}$ & 9,22 & $\mathrm{abAB}$ & 8,42 & $\mathrm{bA}$ & 10,76 & $\mathrm{bC}$ \\
\hline & 9 & 12,30 & $\mathrm{~dB}$ & 11,60 & $\mathrm{bB}$ & 9,04 & bA & 11,63 & bB \\
\hline \multirow{7}{*}{$\mathrm{SA}^{\mathrm{d}}$} & 1 & 918,67 & $\mathrm{c}$ & 962,67 & $\mathrm{~d}$ & & & & \\
\hline & 2 & 845,33 & $\mathrm{a}$ & 880,67 & $\mathrm{c}$ & & & & \\
\hline & 3 & 1125,67 & $\mathrm{eD}$ & 1088,00 & $\mathrm{fC}$ & 1065,67 & $\mathrm{cB}$ & 990,67 & $\mathrm{cA}$ \\
\hline & 4 & 1048,33 & $\mathrm{dD}$ & 866,67 & $\mathrm{bA}$ & 904,00 & $\mathrm{bB}$ & 961,67 & $\mathrm{bC}$ \\
\hline & 5 & 861,33 & $\mathrm{bC}$ & 885,33 & $\mathrm{cD}$ & 794,00 & $\mathrm{aA}$ & 809,33 & $\mathrm{aB}$ \\
\hline & 7 & 926,00 & $\mathrm{cC}$ & 747,00 & $\mathrm{aA}$ & 911,33 & $\mathrm{bB}$ & 1041,00 & $\mathrm{dD}$ \\
\hline & 9 & 1127,00 & $\mathrm{eD}$ & 1005,00 & $\mathrm{eA}$ & 1113,00 & $\mathrm{dC}$ & 1032,67 & $\mathrm{~dB}$ \\
\hline$\overline{\mathrm{SBF}^{\mathrm{e}}}$ & & 0 & & 0,5 & A & 0,6875 & A & 29,5 & B \\
\hline
\end{tabular}

Médias seguidas por letras minúsculas (colunas) iguais não diferem estatisticamente de acordo com o teste de Tukey ( $p=0,05)$.

Médias seguidas por letras maiúsculas (rows) iguais na coluna não diferem estatisticamente de acordo com o teste de Tukey $(p=0,05)$

a DPI= "days post induction".

${ }^{\mathrm{b}}$ U.mg- ${ }^{1}$

${ }^{c} \mu \mathrm{g}$ de ácido gálico.mL de extrato ${ }^{-1}$

${ }^{\mathrm{d}}$ ng.g- ${ }^{1}$.

${ }^{\text {e }}$ Severidade de brusone foliar foi medida seguindo uma escala de notas que varia de 0,5 até $82 \%$ de área foliar afetada. 


\section{Plantas tratadas com o isolado avirulento e desafiadas com isolado virulento}

de M. oryzae (PY10900)

A atividade das proteínas relacionadas à patogênese, concentração de compostos fenólicos e teores de SA foram significantemente influenciadas pelo tratamento com o isolado avirulento bem como pelo desafio com o patógeno virulento, variando na sua quantidade por miligrama de peso fresco. A atividade de GLU foi maior no tratamento induzido com isolado avirulento nas primeiras 24 após o desafio quando comparado com a testemunha. A atividade declinou nos 3 dias seguintes voltando a aumentar e atingindo seu maior valor no último dia avaliado (5DPI). Os valores de PAL apresentaram maior atividade na testemunha no 3, 7 e 9 DPI, e nas plantas induzidas e desafiadas no 2 e 3 DPI. Em folhas das plantas controles e nas plantas induzidas, o concentração de compostos fenólicos foi maior no controle no 1DPI e nas plantas induzidas no 2 DPI. De acordo com os resultados de cromatografia, nas plantas induzidas e desafiadas, a média de componentes fenólicos mostrou um pico de concentração no 3DPI (24hs após o desafio) com valor de $9,07 \mathrm{mg} . \mathrm{FW}^{-1}$, não diferenciando estatisticamente da testemunha, que apresentou concentração de compostos fenólicos maiores no 4, 7 e 9DPI (Tabela 2). A enzima POX mostrou uma maior atividade nas plantas induzidas do que na testemunha já no 1DPI e, excetuando o 2DPI, manteve esse comportamento nos demais tempos analisados, com valor no tratamento onde as plantas foram induzidas, com pico de atividade verificado no 9DPI. No primeiro dia após o desafio, o teor de SA foi maior nas plantas induzidas com o isolado avirulento, entretanto, no dias subsequentes o teor foi menor quando comparado aos valores encontrados na testemunha, aumentando no 9 DPI.

\subsection{Análise de componentes principais (PCA)}

A análise de PCA mostrou que juntos, os três primeiros componentes explicaram $87,87 \%$ da variância observada, com valores de 47, 987\%, 22,658\% e 17,225\%, como demonstrado pela tabela 2. Visto que somados o primeiro e o segundo componentes da PCA, mais de $70 \%$ da variância observada foi explicada, os resultados e a discussão será realizada em cima dos valores apresentados por esses dois primeiros componentes. Em relação às variáveis analisadas, o hormônio SA, os dias após a indução (DPI) foram responsáveis por grande parte das variâncias nos dados. Entre as PRPs avaliadas, GLU foi a que apresentou maior influência na variância. Além dessa, POX e PAL, ambas PRP, mostraram grande atuação na variância observada no segundo componente. 
Ácido salicílico e GLU foram negativamente correlacionadas com DPI (Tabela 3). Essa correlação indica que essas três respostas de defesa foram maiores no início do processo de indução, decrescendo seus níveis com o passar do tempo (Figura 2; Tabela 3). PAL também foi negativamente correlacionada com SA, sugerindo possuir um papel chave na atividade desse hormônio na planta. A atividade de POX mostrou uma forte correlação com a severidade de brusone foliar, onde os tratamentos que apresentaram os maiores níveis dessa enzima foram os que mostraram uma menor área foliar lesionada. 


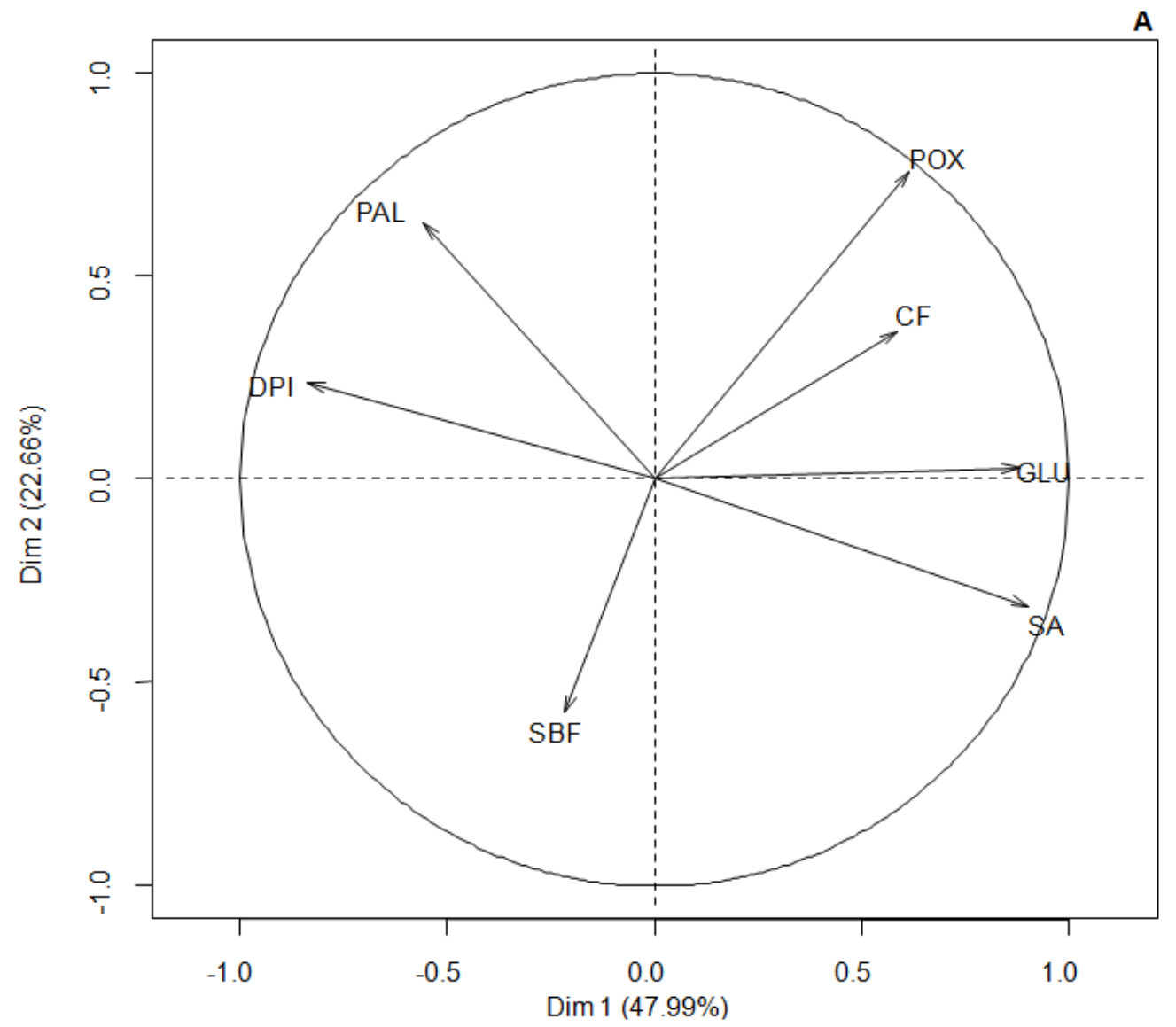

B

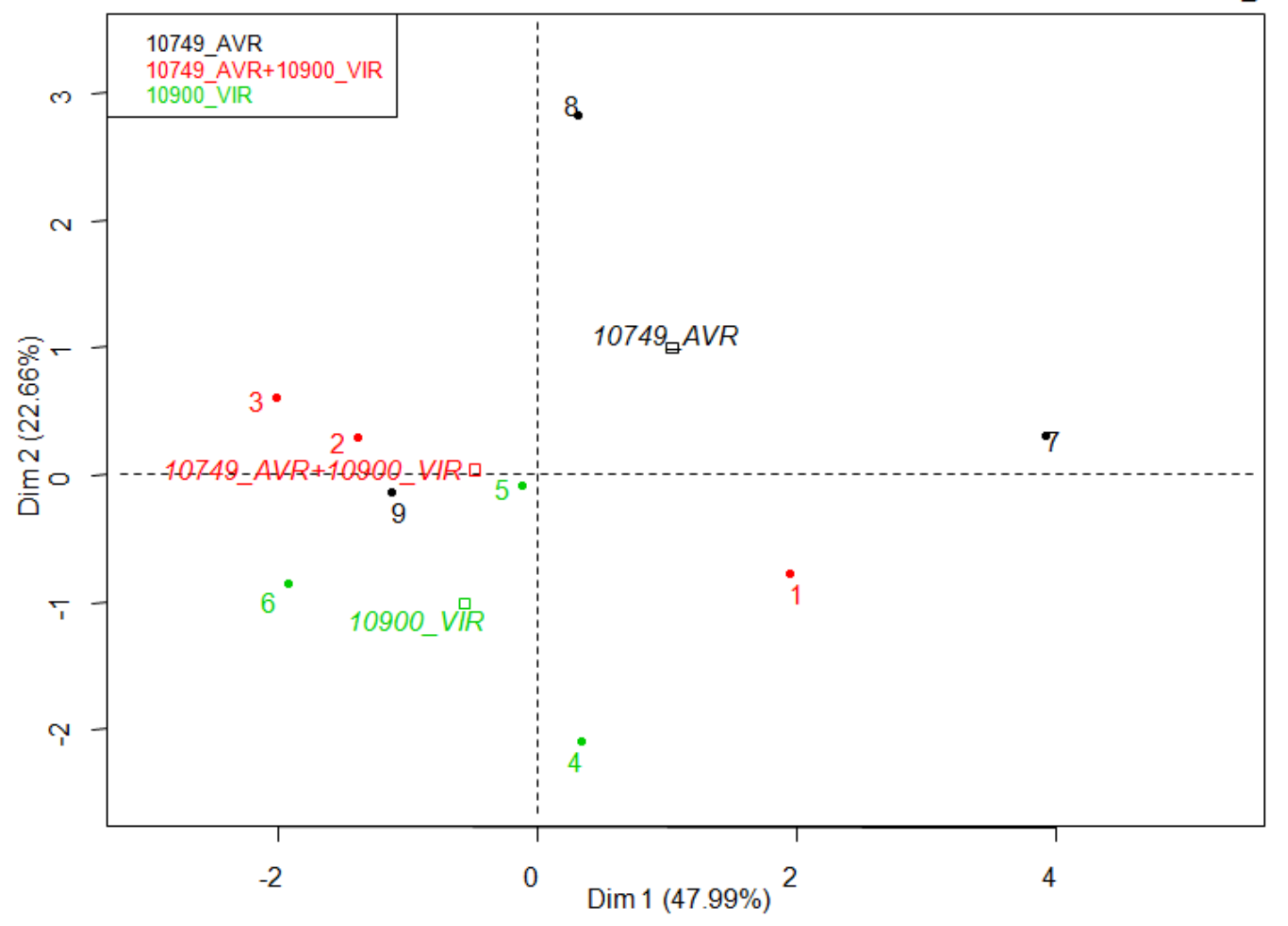

Figura 2 - PCA biplot com variaveis de investigadas na indução de resistência de plantas de arroz com isolado avirulento de $M$. oruzae de acordo com os dois primeiros componentes. A-correlação entre as variáveis; B-distribuição dos dados. 
Tabela3. Matriz de correlação das variáveis relacionadas a indução de resistência em arroz para controle da brusone foliar (Magnaporthe oryzae) por isolado de M. oryzae avirulento (PY10749) e dimensões da análise de componentes principais com significância de $p<0.05$.

\begin{tabular}{lccc}
\hline \multicolumn{1}{c}{ Variáveis } & PCA1 & PCA2 & PCA3 \\
\hline Rice blast severity & $\mathrm{NS}$ & -0.574 & 0.716 \\
Days post induction & -0.835 & $\mathrm{NS}$ & $\mathrm{NS}$ \\
B-1,3 Glucanase & 0.877 & $\mathrm{NS}$ & $\mathrm{NS}$ \\
Peroxidase & $\mathrm{NS}$ & 0.758 & $\mathrm{NS}$ \\
Phenylalanine ammonia-lyase & -0.557 & 0.629 & $\mathrm{NS}$ \\
Phenolic compounds & $\mathrm{NS}$ & $\mathrm{NS}$ & 0.668 \\
Salicylic acid & 0.903 & $\mathrm{NS}$ & $\mathrm{NS}$ \\
Explained Variance & $47,99 \%$ & $22,66 \%$ & $17,22 \%$ \\
Cumulative Variance & $47,99 \%$ & $70,65 \%$ & $87,87 \%$ \\
\hline
\end{tabular}

NS = não significante a $p<0,05$.

\subsection{Colonização de tecidos foliares de arroz cv. Primavera por Magnaporthe} oryzae

\section{Microscopia eletrônica de varredura (MEV) de folhas de arroz}

Nas folhas de arroz da cultivar suscetível induzidas com isolado PY10749 e desafiadas com o isolado virulento PY10900, bem como nas plantas apenas desafiada com o patógeno virulento, foram observados conídios germinados com a formação de apressórios formados e melanizados. Como ilustrado pela MEV (Figura 3), 24 horas após o desafio, o conídio estava murcho e o apressório não estavam mais túrgidos, apresentando-se murchos, indicando que houve sucesso na penetração dos tecidos foliares, possibilitanto o desenvolvimento da infecção. Mesmo nas plantas induzidas previamente com o isolado avirulento, conídios do isolado PY10900 germinaram e formaram apressório melanizado, entretanto, mesmo 48 horas após o desafio (4DPI), os apressórios observados permaneceram túrgidos, indicando que não houve penetração na folha e consequentemente a colonização dos tecidos do mesófilo foliar não aconteceu (Figura 4). Figura 5 representa as plantas- controle $\left(\mathrm{H}_{2} \mathrm{O}\right)$. 


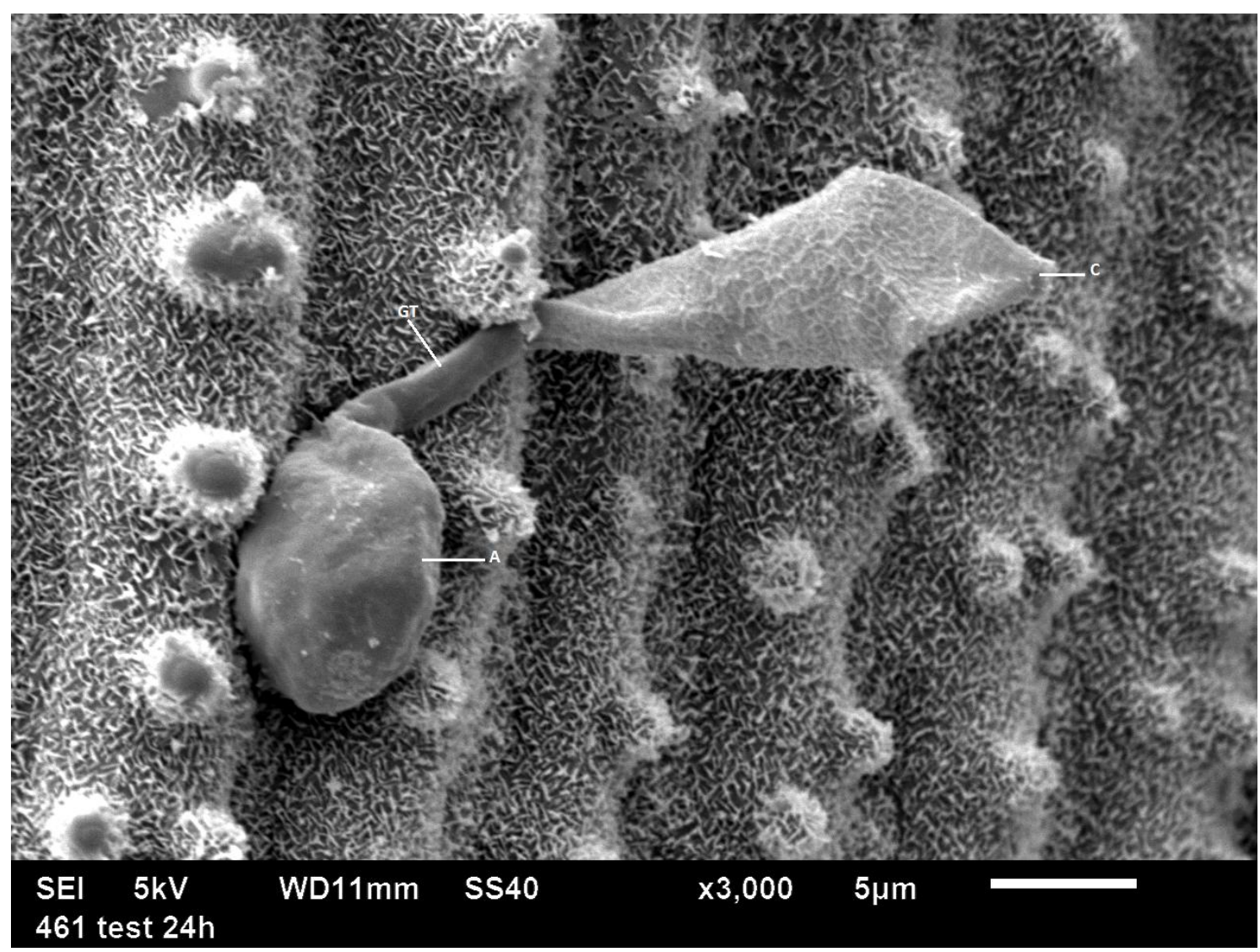

Figura 3 - Observação de microscopia eletrônica de varredura. Folha de arroz inoculada com isolado de Magnaporthe oryzae virulento PY10900 24h após o desafio (3DPI). A: apressório; GT: tubo germinativo; C: conídio. 


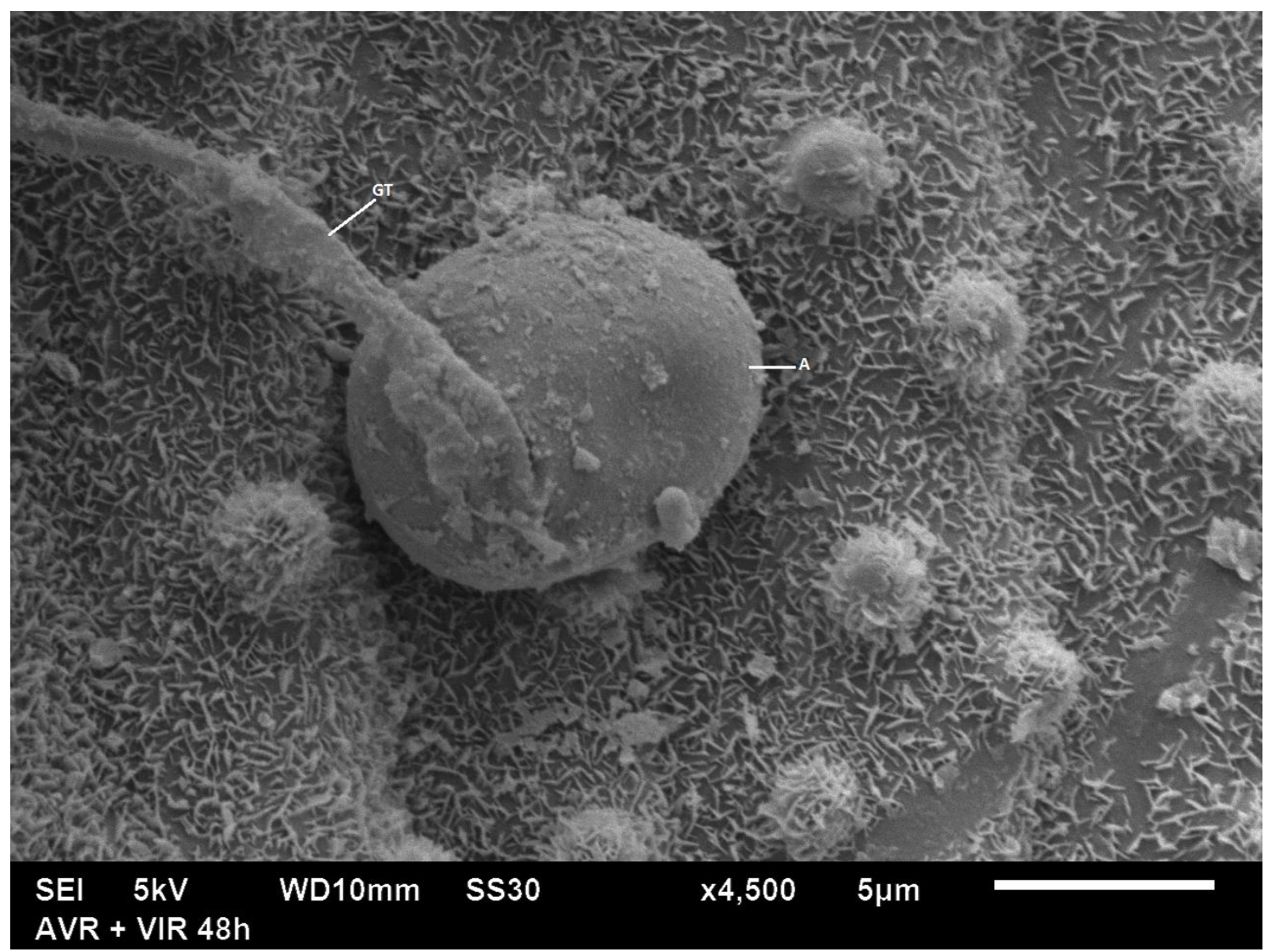

Figura 4 - Observação de microscopia eletrônica de varredura. Folha de arroz induzida com isolado avirulento PY10749 e inoculada com Magnaporthe oryzae virulento 48h após o desafio (4DPI). A: apressório; GT: tubo germinativo. 


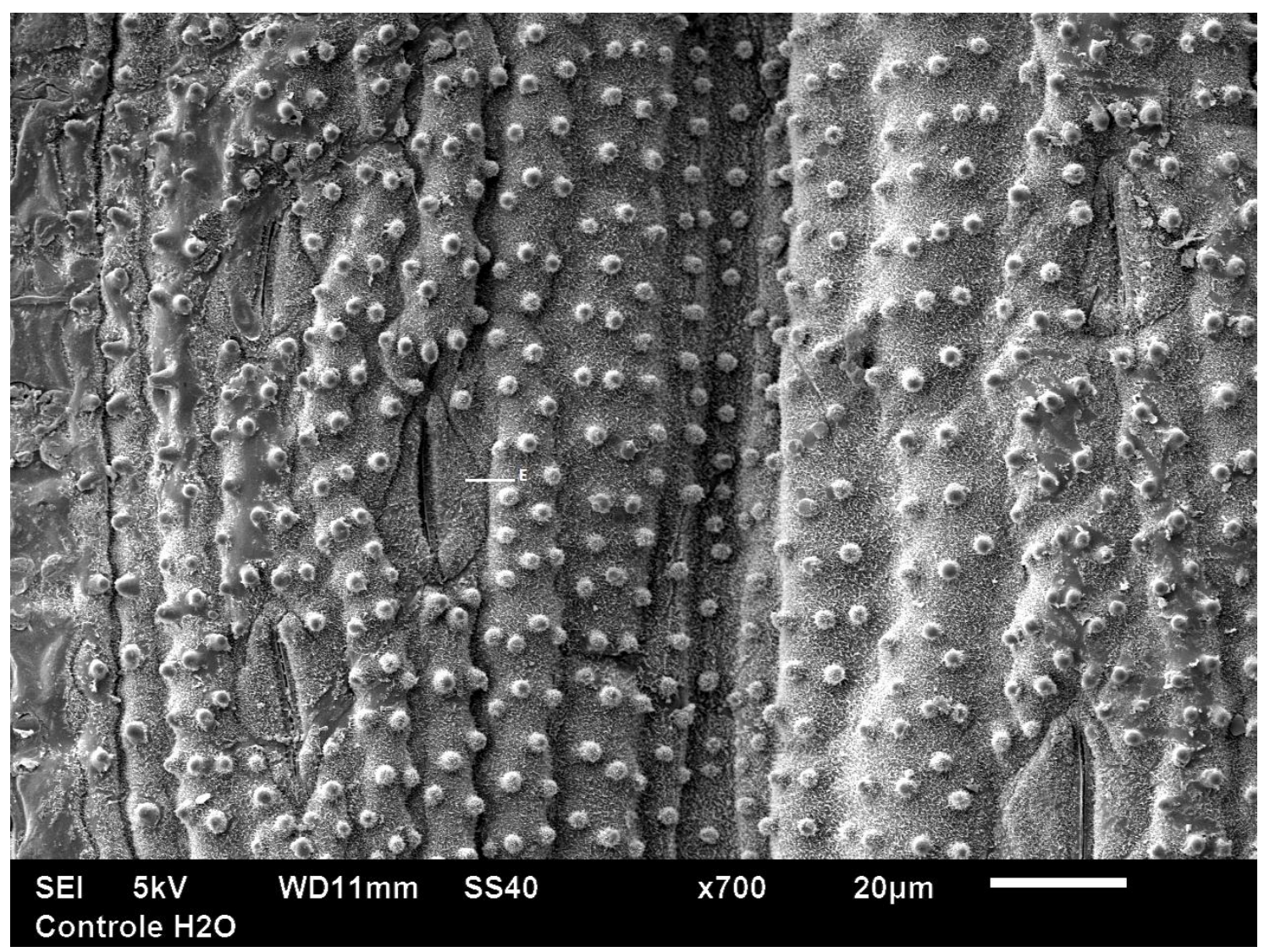

Figura 5 - Observação de microscopia eletrônica de varredura de folha de arroz tratadas com $\mathrm{H}_{2} \mathrm{O}$ (controle). E: estômato.

\section{Microscopia ótica de luz}

Os cortes transversais das folhas de arroz mostraram uma das respostas citológicas de defesas das plantas foi o aparecimento de células com sinais de RH (reconhecidas pela cor castanha) observadas nos sítios de infecção. Nas células adjacentes àquelas com $\mathrm{RH}$, foi observado o acúmulo do conteúdo citoplasmático em vesículas (Figura 6). Essas estruturas também foram observadas nas plantas que foram apenas induzidas com isolado avirulento PY10749 (Figura7) Nas plantas utilizadas como testemunha, o fungo iniciou causou a morte do tecido foliar (Figura 8). Nessa fase, verifica-se a formação de estruturas esporulativas (conidióforos e conídios) no centro das lesões (Figura 1D). Nessas plantas também foi observado o aparecimento do conteúdo citoplasmáticos em vacúolos de células circunvizinhas àquelas infectadas, mas essas respostas não foram efetivas para deter o crescimento fúngico nos tecidos foliares. Algumas células mortas dos tecidos colonizados estavam plasmolisadas, com evidente dimunuição do volume celular, com a membrana plasmática retraída e distante da 
parede celular, sendo que muitas dessas paredes estavam também degradadas (Figura 8).

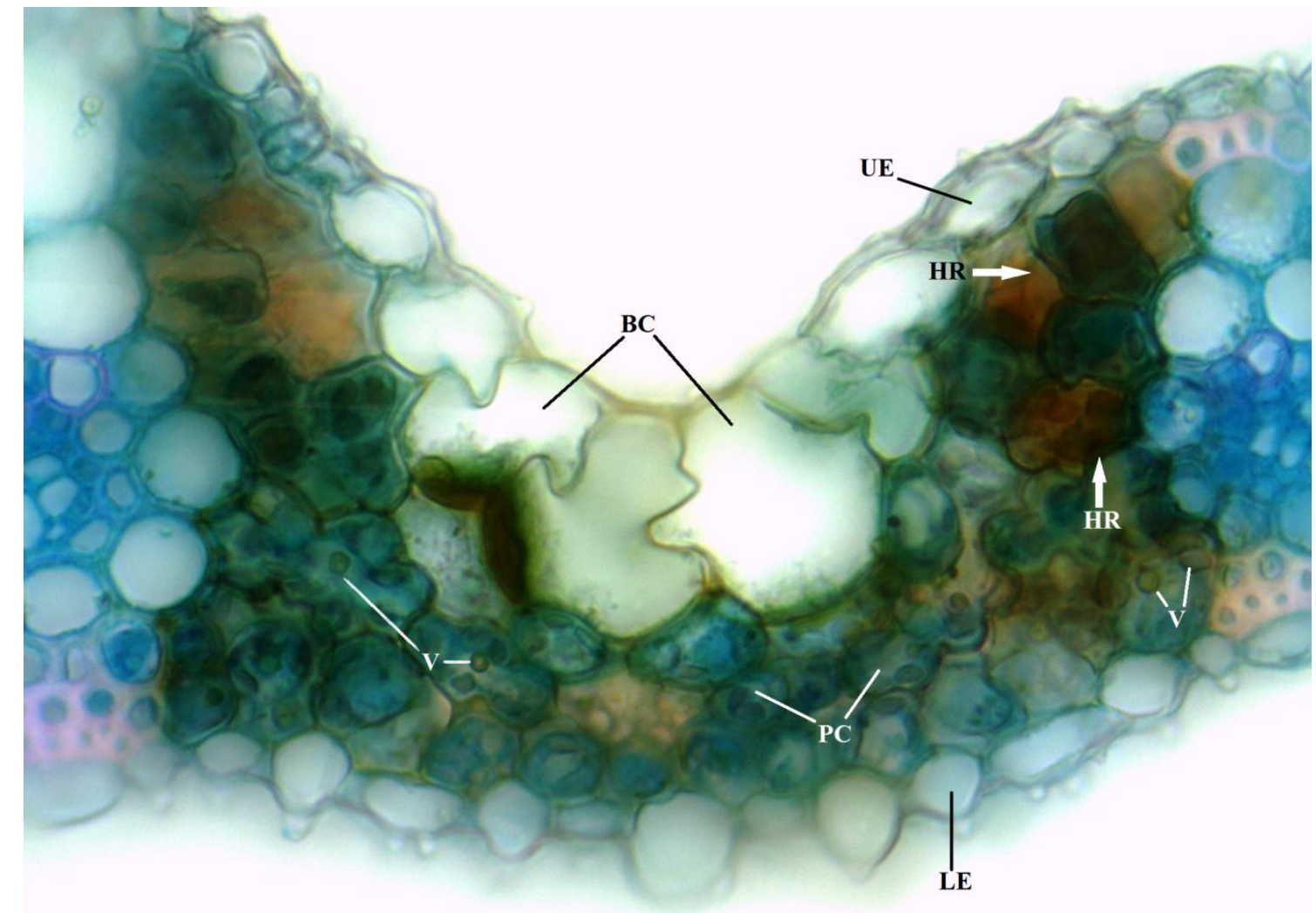

Figura 6 - Microscopia óptica de luz em plantas de arroz. Corte transversal de folhas de plantas induzidas com M. oryzae avirulento (PY10749) e desafiadas 48hs após com M. oryzae virulento (PY10900). BC: células buliformes; UE: epiderme superior; LE: epiderme inferior; PC: parênquima clorofiliano; V: vesículas com conteúdo citoplasmático; HR: reação de hipersensibilidade - células mortas. 


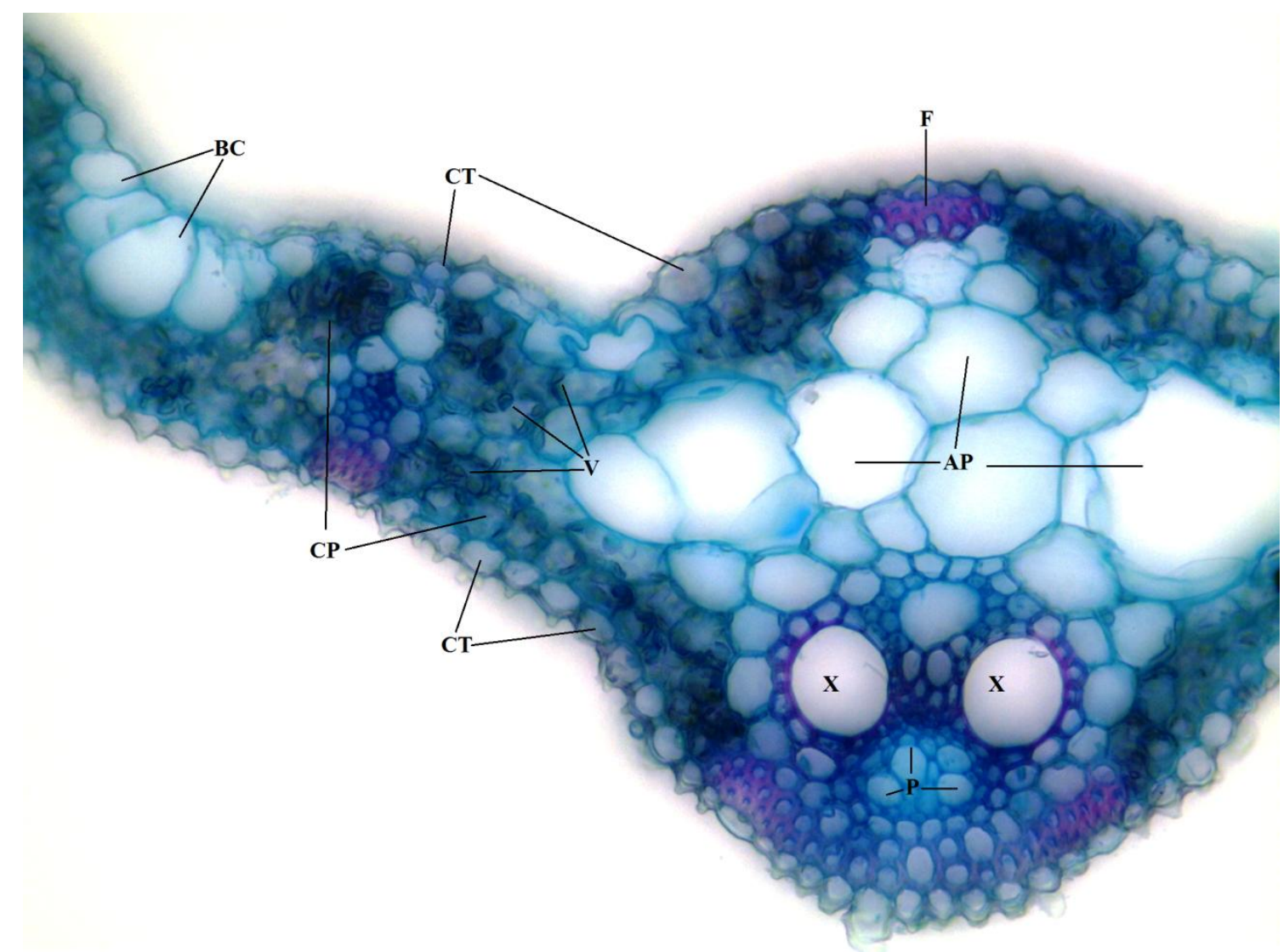

Figura 7 - Microscopia óptica de luz em plantas de arroz. Corte transversal de folhas de plantas induzidas com M. oryzae avirulento (PY10749). AP: parênquima aquífero; BC: células buliformes; CP: parênquima clorofiliano; CT: células propriamente ditas; F: fibras; V: vesículas com conteúdo citoplasmático; P: floema; X: xilema. 


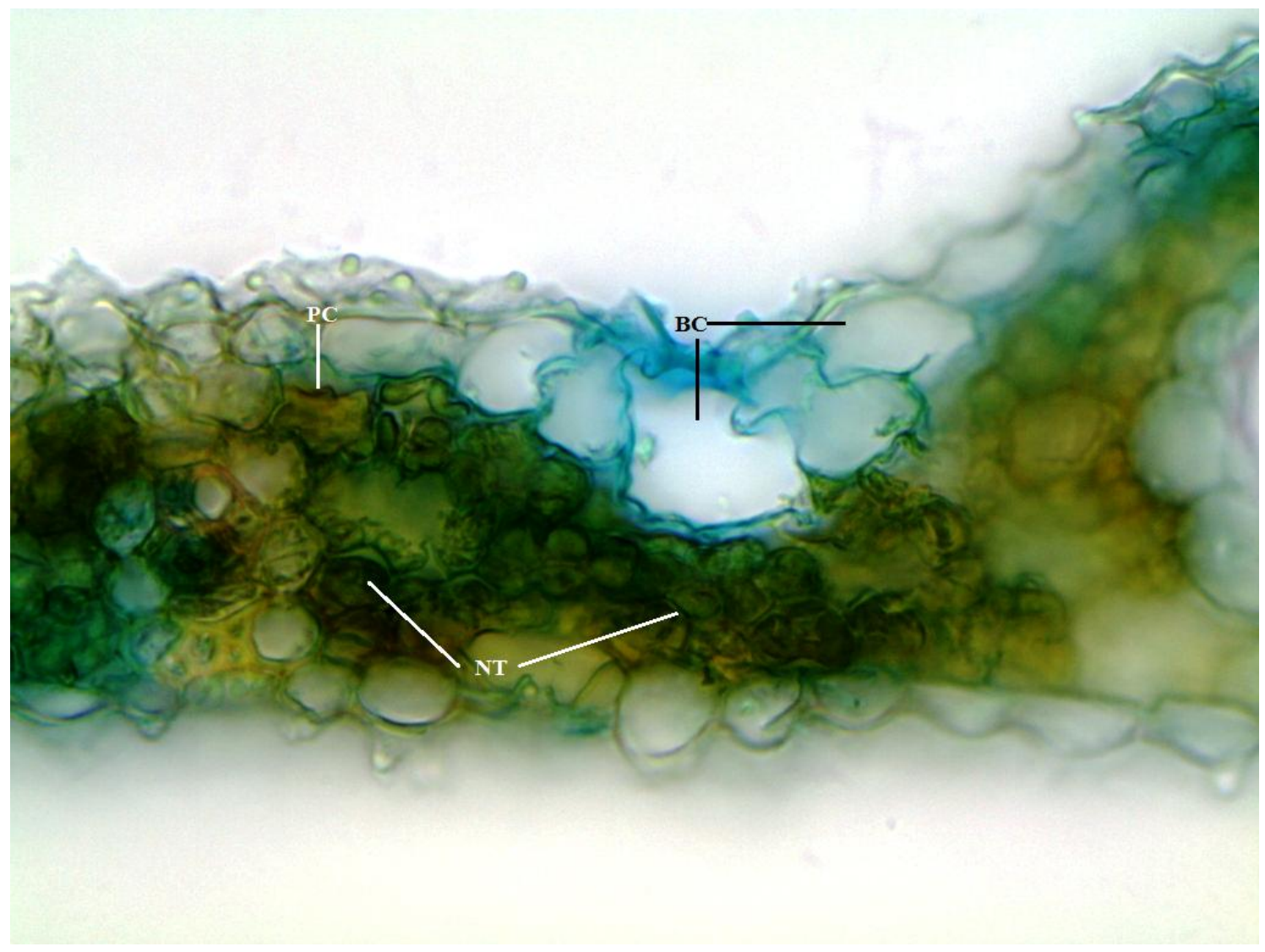

Figura 8 - Microscopia óptica de luz em plantas de arroz. Corte transversal em folhas de plantas desafiadas com PY10900 virulento (testemunha). BC: células buliformes; PC: célula plasmolisada; NT: tecido necrosado.

\section{Deposição de calose em cortes paradérmicos}

A observação por meio de microscopia de epiflorescência revelou a deposição de calose na parede celular de células epidérmicas das folhas de plantas induzidas com isolado PY10749 e desafiadas com PY10900, com fluorescência nas células vizinhas às lesões. Não foi observada fluorescência nos outros tratamentos (Figura 9). 


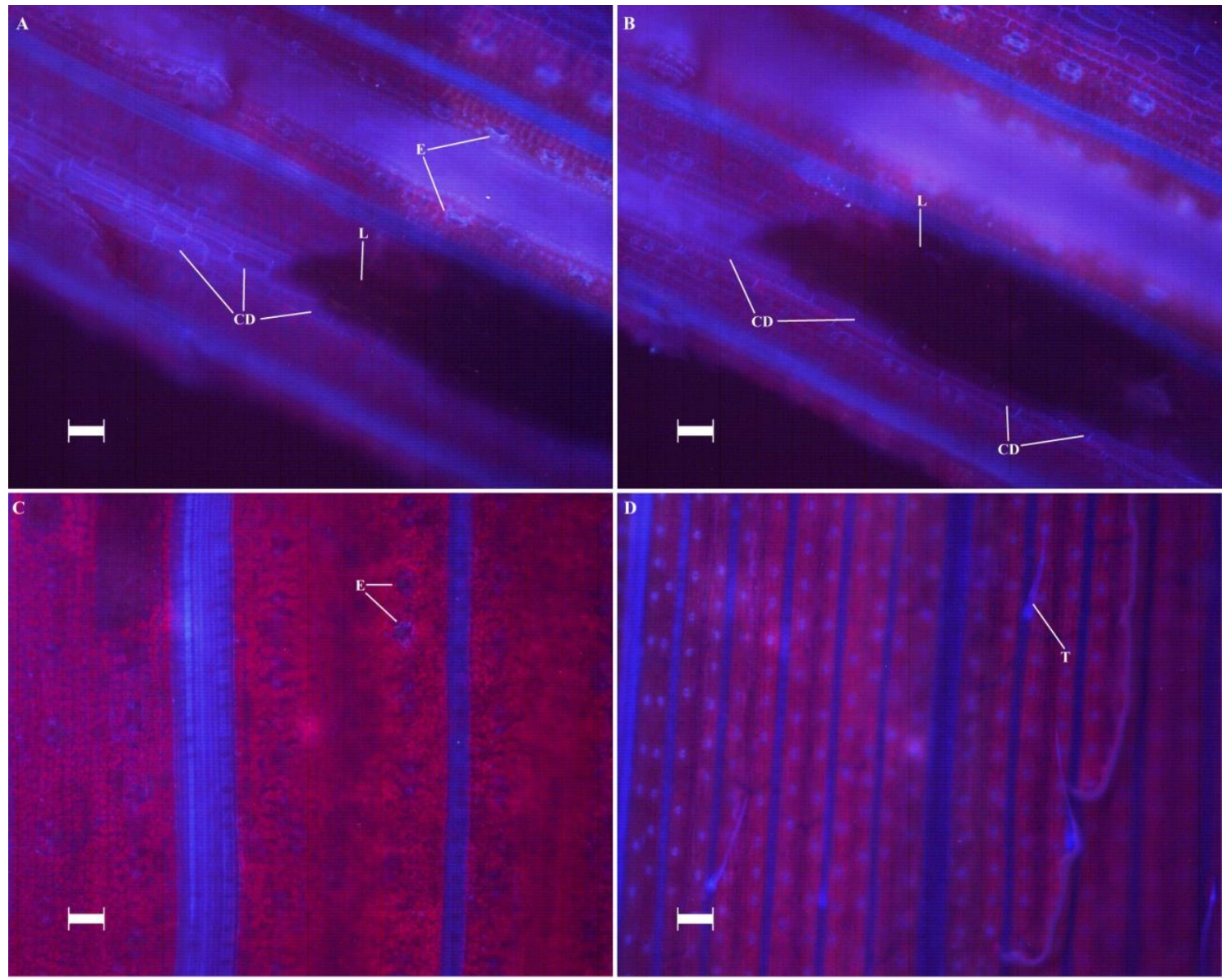

Figura 9 - Observação de microscopia óptica de epifluorescência. A e B: plantas de arroz induzidas com isolado PY10749 e desafiados com PY10900 mostrando células epidérmicas com flurescência indicando deposição de calose (CD) ao redor de áreas lesionadas (L); C: plantas tratadas com PY10900 (E=estômatos); D: plantas controle $\left(\mathrm{H}_{2} \mathrm{O}\right)$ com tricomas $(\mathrm{T})$. 


\section{DISCUSSÃO}

Neste trabalho, a indução de resistência foi comprovada em plantas de arroz contra $M$. oryzae utilizando um isolado avirulento deste mesmo patógeno. Este trabalho é pioneiro no estudo da interação das variáveis de defesa bioquímicas e estruturais em plantas de arroz induzidas com isolado avirulento de M. oryzae. A porcentagem de área foliar afetada foi significativamente maior nas plantas desafiadas com isolado virulento do que nas plantas que, mesmo desafiadas, foram previamente inoculadas com isolado avirulento de $M$. oryzae (Figura 1), com diferenças também no tipo de lesão. A ativação de mecanismos de defesa pode levar a uma rápida resposta da planta ao ataque de patógenos, o que pode ter acontecido nas plantas induzidas com $M$. oryzae avirulento com a presença de HR. Essa mudança no metabolismo da planta induz à uma alteração na bioquimica da célula, restringindo a colonização de seus tecidos por delimitar a região infectada pelo patógeno, levando a uma reação de hipersensibilidade (HR) (Kunstler et al., 2016). Em arroz, as lesões do tipo HR caracterizam-se por serem pontuais, não abertas e não esporulativas. Esse tipo de lesão é demonstrada nas figuras 1B e 1C, onde pontuações marrons indicam necrose celular nos sítios de penetração do patógeno. Essa morte celular causada pela HR desencadeia uma resposta de defesa local e sistêmica, iniciando, por exemplo, a produção de fitoalexinas, espécies reativas de oxigênio e ativação de proteínas relacionadas a patogênese (Dickman \& Fluhr, 2013). Essa resposta indica que há uma relação raça-específica entre o gene $\mathrm{R}$ do hospedeiro e o gene Avr do patógeno, entretanto, a inoculação do isolado avirulento conferiu resistência à planta contra o isolado PY10900, mesmo este isolado sendo virulento à cultivar BRS Primavera. Resultados de outro trabalho indicaram essa especificidade entre genes $\mathrm{R}$ e genes Avr, onde isolados avirulentos de $M$. oryzae conferiu proteção às planta de arroz mesmo contra raças de $M$. oryzae virulentas, aquelas capazes de estabelecer infecção (Filippi et al., 2007).

Verificou-se diferenças nas atividades de PRPs entre os tratamentos utilizados antes do desafio com $M$. oryzae virulento. A atividade de GLU foi aumentada pela presença do isolado avirulento PY10749. O valor de GLU foi constante nos dois primeiros dias após a indução e foi maior do que os valores encontrados no controle $\left(\mathrm{H}_{2} \mathrm{O}\right)$ (Tabela 2). No 3DPI, quando as plantas induzidas foram inoculadas (AVR+VIR) (24hs após o desafio com M. oryzae virulento) a atividade de GLU continuou mais alta, com 38,75 U.mg ${ }^{-1}, 28,3 \%$ maior do que na testemunha. Esses resultados sugerem que 
que a presença do fitopatógeno, avirulento ou virulento, possui a habilidade de intensificar a atividade de enzimas glucanases, já que essas enzimas hidrolisam os polímeros de $\beta$-1,3-glucana, um dos principais constituintes da parede celular de fungos (Ferreira et al., 2007). A atividade de POX foi estimulada nas plantas induzidas com isolado AVR, aumentando significativamente nas primeiras horas após a indução, aumentando mais de três vezes no 1DPI e o dobro do valor observado no 2DPI, em relação ao controle. Durante uma interação patógeno-hospedeiro, a resistência raçaespecífica age de forma específica e rápida, reconhecendo o patógeno e levando a ativação de respostas de defesa (Veneault-Fourrey et al., 2005). O número de lesões do tipo HR foi alta tanto nas plantas induzidas com isolado avirulento quanto naquelas induzidas e desafiadas com isolado virulento. Peroxidases são produzidas pela planta hospedeira também em respostas a estresses bióticos, pode produzir espécies reativas de oxigênio e levar a uma resposta de hipersensibilidade, ativando o fortalecimento da parede celular e aumentando a produção de lignina (Camejo et al., 2016).

Os valores e o padrão de atividade de PAL não foram os mesmos de GLU, onde os valores desta enzima foram maiores no controle do que nas plantas induzidas no período que antecedeu ao desafio, oscilando nos períodos subsequentes avaliados. PAL é a primeira enzima na via de biossíntese dos fenilpropanoides e possui uma importante função nas plantas após o ataque de patógenos (Zabala et al., 2006) entretanto, diferente de outros trabalhos em que apresentou uma atividade maior nas plantas induzidas do que nos controles/testemunhas, PAL mostrou um padrão diferente de indução após o contato com M. oryzae, onde os maiores valores foram encontrados no controle $\left(\mathrm{H}_{2} \mathrm{O}\right)$ e na testemunha (M. oryzae).

Assim como PAL, uma enzima que atua na biossíntese de compostos fenólicos com atividade antimicrobiana (Montesinos, 2000), os valores dos compostos fenólicos (CF) também foram menores nas plantas desafiadas com M. oryzae, entretanto, nos dois primeiros dias após a indução a sua quantidade manteve-se constante e no primeiro dia após o desafio (3DPI), o tratamento AVR+VIR apresentou concentração de CF superior ao encontrado na testemunha (Tabela 2). Compostos fenólicos são produtos do metabolismo secundário das plantas e possuem atividade antimicrobiana, podendo ser induzidos por patógenos em respostas de defesa das hospedeiras (Ferreira et al., 2007).

O tratamento das plantas com o isolado de $M$. oryzae avirulento (AVR) desencadeou um aumento no teor de SA, permanecendo alto no dia subsequente ao do desafio (3DPI). A presença de patógenos pode desencadear um aumento no nível de SA 
em hospedeiras (De Vleesschauwer et al., 2013) nada obstante, o alto nível de SA nos controles $\left(\mathrm{H}_{2} \mathrm{O}\right)$. Diferente das dicotiledôneas, nas quais os níveis de SA são baixos e podem aumentar exponencialmente durante o ataque de patógenos, as plantas de arroz acumulam altos níveis deste hormônio mesmo em condições de não-infecção (Silverman et al., 1995).

Neste trabalho, PCA revelou como os mecanismos de indução de resistência interagiram e como essa interação influenciou as respostas de defesa da planta para controle da brusone foliar. Utilizando apenas três componentes, a PCA resumiu mais 87\% da variância observada (Tabela 3). A variável DPI está negativamente correlacionada com a atividade de GLU e com o teor de SA, onde níveis decresceram com o passar do tempo e, cujos valores maiores de avitidade de teor, respectivamente, foram encontrados nos tratamentos induzidos e desafiados com M. oryzae. SA também foi correlacionado negativamente com o a enzima PAL. Houve uma alternância entre a atividade de PAL e o teor de SA. Quando o valor de uma dessas variáveis subia, o valor da outra decrescia (Tabela 2). PAL é uma enzima chave na síntese dos fenilpropanóides e tem no ácido trans-cinamico, precursor do SA, o seu substrato. Sua atividade decresce a medida que o substrato é consumido e o produto da reação vai sendo formado (Ferreira et al., 2007). A correlação entre SBF e a atividade de POX foi negativa no segundo componente da PCA. Os tratamento com menores índices de área foliar afetada foram aqueles nos quais observou-se uma maior atividade de POX. Isso sugere que essa enzima contribuiu para que a infecção não ocorresse. A atividade de peroxidase da família PR9 pode agir no fortalecimento da parede celular por meio da catálise da lignina, como também pode atuar contra o patógeno através de respostas rápidas que podem levar à uma HR (Camejo et al., 2016). A variável CF correlacionou-se positivamente com o aumento da severidade da brusone foliar. Esta correlação pode ser atribuída à presença crescente do patógeno em desenvolvimento provocando o progresso contínuo da doença. Os compostos fenólicos possuem atividade antimicrobiana, como as fitoalexinas, mecanismos de defesa induzidos em resposta ao ataque de fitopatógenos (Kuc, 1995).

A análise da superfície foliar via MEV ilustrou e comparou o início do processo de colonização, evidenciando a formação de apressórios tanto na testemunha (PY10900) bem como nas plantas tratadas com PY10749 + PY10900. Na figura 3 pode-se observar que o apressório formado deu continuidade ao processo de colonização ao penetrar no tecido foliar nas primeiras $24 \mathrm{hs}$ após o desafio nas plantas não induzidas. Já no 
tratamento PY10749 + PY10900, mesmo após 48hs o apressório permaneceu túrgido, sugerindo que não houve sucesso na penetração na folha (Bechinger et al., 1999).

Os cortes das folhas observados em microscopia óptica revelaram a presença de grupos de células mortas nas plantas induzidas com isolado avirulento e desafiadas com M. oryzae virulento, sem a presença de crescimento micelial do patógeno (Figura 6), como também não revelaram nenhum sintoma de brusone foliar (Figura 1). Manchas necróticas características de respostas de hipersensibilidade e a presença de vesículas com conteúdo citoplasmático marrons foram observadas tanto nas plantas somente induzidas no 2DPI (Figura 7), como também nas plantas desafiadas, no 4 DPI (segundo dia após o desafio) (Figura 6), confirmando a ocorrência da indução de resistência. As reações de hipersensibilidade estimulam a produção de compostos que fortificam a parece celular fazendo-a mais resistente à pressão mecânica aplicada durante a penetração feita pelo apressório, além de levar ao acumulo de produtos de oxidação fenólica amarronzados (Heath, 2000; Bolwell et al., 2001; Kadota et al., 2015).

Observou-se a fluorescência de células epidérmicas nas plantas induzidas e desafiadas, indicando a presença de calose na parede celular vegetal. A deposição desses compostos na parede celular é uma reação de defesa a estresses bióticos e, juntamente com acumulação de EROs e compostos fenólicos, constituem em mecanismos de indução de defesa contra o ataque de patógenos. 


\section{CONCLUSÃO}

Plantas induzidas com isolado avirulento PY10749 apresentaram uma área foliar afetada significativamente menor; nestas não houve o estabelecimento da infecção. Após o desafio com isolado virulento de M. oryzae (PY10900), a resistência das plantas mostrou-se estar relacionada com um rápido reconhecimento do patógeno, expressa por meio de uma resposta de hipersensibilidade.

Conídios do fitopatógeno germinaram e formaram apressório, entretanto não foram capazes de penetrar a folha das plantas previamente induzidas com isolado avirulento. O tratamento das plantas com PY10749 também foi eficiente em impedir a colonização das plantas por $M$. oryzae virulento, com a formação de estruturas vesiculares nas plantas previamente induzidas.

Em plantas de arroz, o isolado PY10749 aumentou a atividade das enzimas de defesa GLU, PAL e POX, além de aumentar a concentração de CF e SA nos primeiros dias após o desafio com PY10900. SAR em arroz desencadeada por M. oryzae avirulento pode estar associada a essas cinco variáveis de defesa. Estudos como este de interação planta-patógeno ajuda na elucidação dos mecanismos pelos quais a célula vegetal lida com essas situações de estresse. Uma visão geral das variáveis de defesa foi dada pela análise multivariada, estabelecendo a importância da relação entre as respostas de defesa desencadeadas pelo isolado avirulento para o controle da brusone foliar. 


\section{LITERATURA CITADA}

BECHINGER, C.; GIEBEL, K.F.; SCHNELL, M.; LEIDERER, P.; DEISING, H.B. \& BASTMEYER, M.. 1999. Optical measurements of invasive forces exerted by appressoria of a plant pathogenic fungus. Science 285:1896-9.

BOLWELL, P.P.; PAGE, A.; PISLEWSKA, M., \& WOJTASZEK, P. 2001. Pathogenic infection and the oxidative defences in plant apoplast. Protoplasma 217:20-32.

BRADFORD, M. 1976. A rapid and sensitive method for the quantification of microgram quantities of protein utilizing the principle of protein-dye binding. Annals of Biochemistry 72:248-254.

CAMEJO, D.; GUZMÁN-CEDEÑO, A. \& MORENO, A. 2016. Reactive oxygen species, essential molecules, during plant-pathogen interactions. Plant Physiology and Biochemistry 103:10-23.

CÔRTES, M.V.C.B.; VIANA, H.F.; SILVA, F.R.; SILVA-LOBO, V.L.; SILVA, G.B.; PRABHU, A.S. \& FILIPPI, M.C.C. 2008. Quantificação da atividade enzimáticas de proteínas relacionadas à patogênese no patossistema Oryza sativa/Magnaporthe oryzae. Embrapa Arroz e Feijão, Santo Antônio de Goiás.

DANGL, J.L.; HORVATH, D.M. \& STASKAWICZ, B.J. 2013. Pivoting the plant immune system from dissection to deployment, Science 341:746-751.

DAYMI, C.; GUZMÁN-CEDEÑO, A. \& MORENO, A. 2016. Reactive oxygen species, essential molecules, during plant-pathogen interactions. Plant Physiology and Biochemistry 103:10-23.

DEAN R, VAN KAN JAL, PRETORIUS ZA, HAMMOND-KOSACK KE, DI PIETRO A, SPANU PD, RUDD JJ, DICKMAN M, KAHMANN R, ELLIS J, FOSTER GD 2012. The Top 10 fungal pathogens in molecular plant pathology. Molecular Plant Pathology, 13:414-430 
DICKMAN, M.B. \& FLUHR, R. 2013. Centrality of Host Cell Death in Plant-Microbe Interactions. Annual Review of Phytopathology 51:543-70.

DICKO, M.H.; HILHORST, R.; GRUPPEN, H.; TRAORE, A.S.; LAANE, C.; van BERKEL, W.J.H. \& VORAGEN, A.G.J. 2002. Comparison of content in phenolic compounds, polyphenoloxidase, and peroxidase in grains of fifty sorghum varietis from Burkina Faso. Journal of Agricultural and Food Chemistry 50:3780-3788.

DONG, X.; HONG, Z.; CHATTERJEE, J. \& KIM S, VERMA, D.P.S. 2008. Expression of callose synthase genes and its connection with Npr1 signaling pathway during pathogen infection. Planta 229:87-98.

FAULKNER, C. \& ROBATZEK, S. 2012. Plants and Pathogens: putting infection strategies and defence mechanisms on the map. Current Opinion in Plant Biology, 15:699-707.

FERREIRA, R.B.; MONTEIRO, S.; FREITAS, R.; SANTOS, C.N.; CHEN, Z.; BATISTA, L.M.; BORGES, A. \& TEIXEIRA, A.R. 2007. The role of plant defence proteins in fungal pathogenesis. Molecular Plant Pathology 8:677-700.

FILIPPI, M.C. \& PRABHU, A.S. 2001. Phenotypic virulence analysis of Pyricularia grisea isolates from Brazilian upland rice cultivars. Pesquisa Agropecuária Brasileira 36:27-35.

FILIPPI, MARTA C.C.; SILVA, GISELE B. \& PRABHU, ANNE S. 2007. Indução de resistência à brusone em folhas de arroz por isolado avirulento de Magnaporthe oryzae. Fitopatologia Brasileira 32:387-392.

HEATH, M.C. 2000. Hypersensitive response-related death. Plant Molecular Biology 44:321-34.

KADOTA, Y.; SHIRASU, K. \& ZIPFEL, C. 2015. Regulation of the NADPH Oxidase RBOHD during plant immunity. Plant and Cell Physiology 56:1472-1480. 
KEESEY, J., 1987. Biochemica Information. Boehringer Manhein Biochemicals, Indianapolis.

KRAUS, J.E.; SOUSA, H.C.; RESENDE, M.H.; CASTRO, N.M.; VECCHI, C. \& LUQUE, R. 1998. Astra blue and basic fuchsin double staining of plant material. Biotechnic \& Histochemistry 73:235-24.

KUC, J. 1995. Phytalexins, stress metabolism, and disease resistance in plants. Annual Review of Phytopathology 33:275-97.

KUNSTLER, A.; BACSO, R.; GULLNER, G.; HAFEZ, Y.M. \& KIRALY, L. 2016. Staying alive - is cell death dispensable for plant disease resistance during the hypersensitive response? Physiological and Molecular Plant Pathology 93:75-84.

MEHER, H.C.; GAJBHITE, V.T. \& SINGH, G.A. 2012. Liquid chromatography method for determination of selected amino acids, coenzymes, growth regulators, and vitamins from Cicer arietinum (L.) and Solanum lycopersicum (L.). Journal AOAC International 95:1142-1152.

MONACO, M.K.; STEIN, J.; NAITHANI, S.; WEI, S.; DHARMAWARDHANA, P.; KUMARI, S.; AMARASINGHE, V.; YOUENS-CLARK, K.; THOMASON, J.; PREECE, J.; PASTERNAK, S.; OLSON, A.; JIAO, Y.; LU, Z.; BOLSER, D.; KERHORNOU, A.; STAINES, D.; BRANDON, W.; WU, G.; D'EUSTACHIO, P.; HAW, R.; CROFT, D.; KERSEY, P.J.; STEIN, L.; JAISWAL, P. \& WARE, D. 2013. Gramene 2013: comparative plant genomics resources. Nucleic Acids Research 42: 1193-1199.

MONTESINOS, E. (2000) Pathogenic plant-microbe interactions. What we know and how we benefit. Int. Microbiol. 3, 69-70.

NOTTEGHEM, J.L. 1981. Cooperative experiment on horizontal resistance to rice blast. In: BLAST and upland rice: report and recommendations from the meeting 
for international collaboration in upland rice improvement. International Rice Research Institute, Los Baños, pp 43-51.

PAN, S.Q.; YE, X.S. \& KUC, J. 1991. Association of a b-1,3-glucanase activity and isoform pattern with systemic resistance to blue mold in tobacco induced by stem injection with Peronospora tabacina or leaf inoculation with tobacco mosaic virus. Physiological and Molecular Plant Pathology 39:25-39.

SAIKIA, S.; PARKER, E.J.; KOULMAN, A. \& SCOTT, B. 2006. Four gene products are required for the fungal synthesis of the indole-diterpene, paspaline. FEBS Letters 580:1625-1630

SPOEL, S.H. \& DONG, X. 2012. How do plants achieve immunity? defense without specialized immune cells. Nature Review of Immunology 12:89-100.

STRANGE, R.N. \& SCOTT, P.R. 2005. Plant disease: a threat to global food security. Phytopathology 43: 83-116.

TSUDA, K. \& KATAGIRI, F. 2010. Comparing signaling mechanisms engaged in pattern triggered and effector-triggered immunity, Current Opinion on Plant Biology. 13:459-465.

VENEAULT-FOURREY, C.; LAUGÉ, R. \& LANGIN T. 2005. Nonpathogenic strains of Colletotrichum lindemuthianum trigger progressive bean defense responses during appressorium-mediated penetration. Applied Environmental Microbiology 71:4761-70.

De VLEESSCHAUWER, D.; GHEYSEN, G. \& HOFTE, M. 2013. Hormone defense networking in rice: tales form a different world. Trends in Plant Science 18:555565.

ZABALA, G.; ZOU, J.J.; TUTEJA, J.; GONZALEZ, D.O.; CLOUGH, S.J. \& VODKIN, L.O. 2006. Transcriptome changes in the phenylpropanoid pathway 
of Glycine max in response to Pseudomonas syringae infection, BMC Plant Biology 6:26-43. 


\section{CAPÍTULO 3}

Indução de resistência em arroz por meio de indutores abióticos para controle de Magnaporthe oryzae. 
Indução de resistência em arroz por meio de indutores abióticos para controle de Magnaporthe oryzae.

\section{RESUMO}

Acibenzolar-S-metil (ASM) e ácido jasmônico (JA) são indutores abióticos capazes de ativar respostas de defesa de plantas. A comunicação existente entre as rotas de sinalização ativadas por ASM e JA, comumente se manifesta como um antagonismo recíproco. Foi examinado o efeito de ambos no controle da brusone do arroz a fim de revelar como o processo de indução de defesa desencadeada por eles e interferência nas atividades de $\beta$-1,3-glucanase (GLU), fenil alanina-amônio liase (PAL), Lipoxigenase (LOX), Peroxidase (POX), compostos fenólicos (CF) totais, teor de ácido salicílico (SA) e no desenvolvimento da doença. Plantas de arroz foram tratadas com JA, ASM e com a mistura de ambos (JA+ASM) e então desafiadas com Magnaporthe oryzae. ASM pode ativar a resistência sistêmica induzida; JA promoveu um aumento da suscetibilidade de arroz ao ataque de $M$. oryzae. O antagonismo entre ASM e JA foi demonstrado pela aplicação conjunta de ambos, onde a severidade de brusone foliar (SBF) foi maior em plantas induzidas com ASM mas foi menor do que aquelas tratadas com JA. A atividade de LOX, maior em plantas tratadas com JA, mostrou estar correlacionado positivamente com o aumento da severidade. Plantas tratadas com ASM que apresentaram maior atividade de POX tiveram menor SBF. Esta enzima mostrou estar ligada ao metabolismo secundário de defesa devida a sua correlação com componentes da via dos fenilpropanóides como PAL, SA e compostos fenólicos (CF). Este é o primeiro relado de efeito cruzado entre ASM e JA em arroz.

Palavras-chaves: Acibenzolar-S-metil, ácido jasmônico, brusone, crosstalk, fitormônios, lipoxigenase, Oryza sativa. 
Induction of resistance in rice by abiotic inducers to control M. oryzae.

\begin{abstract}
Acibenzolar-S-methyl (ASM) and jasmonic acid (JA) are abiotic inducers capable of activating plant defense responses. The cross-talk between the ASM and JAactivated pathways commonly manifests as reciprocal antagonism. We examined the effect of both on rice blast control in order to discover how the induction triggered by them and their reciprocal interaction interfere with the defense responses and disease development. Rice plants were treated with JA, ASM and the mixture of both (JA + ASM) and then challenged with Magnaporthe oryzae. ASM can activate systemic resistance induced; JA promoted an increase in rice susceptibility to $M$. oryzae attack. The antagonism between ASM and JA was demonstrated by the joint application of both, where rice blast severity (SBF) was higher in ASM-induced plants but was lower than those treated with JA. Lipoxygenase activity (LOX), higher in plants treated with JA, was positively correlated with increased severity. Plants treated with ASM that had higher peroxidase activity (POX) had lower SBF. This enzyme has been shown to be linked to secondary defense metabolism due to its correlation with phenylpropanoid pathway components such as phenylalanine ammonia-liase (PAL), salicylic acid (SA) and phenolic compounds (CF). This is the first report of cross-effect between ASM and $\mathrm{JA}$ in rice.
\end{abstract}

Key words: Acibenzolar-S-methyl, crosstalk, jasmonic acid, phytormons, lipoxygenase, rice blast, Oryza sativa. 


\section{INTRODUÇÂO}

Plantas possuem mecanismos de defesa latentes que podem ser ativados ou reforçados quando em contato com agentes indutores, onde vias sinalizadoras governadas por hormônios vegetais têm papel preponderante.

O ácido salicílico (SA) é um hormônio fenólico, derivado do triptofano e está envolvido em diversos processos metabólicos (Vlot et al., 2009). O aumento da concentração de SA nas plantas pode desencadear resistência sistêmica adquirida (SAR). Este fenômeno é associado com o acúmulo de SA; este hormônio é requerido para a transdução de sinal, sendo efetivo na elicitação das defesas contra patógenos biotróficos. A ativação de genes relacionados à patogênese (PR), acúmulo de proteínas PR (PRPs), produção de espécies reativas de oxigênio e síntese de fitoalexinas, fazem parte das mudanças expressada pela planta quando tem suas defesas elicitadas por SA (Thaler et al., 2012; Camejo et al., 2016). A aplicação exógena de SA e seus análogos, como acibenzolar-S-metil (ASM) em plantas pode induzir resistência contra diversos fitopatógenos (de Vleesschauwer et al., 2013). O uso do ativador de plantas ASM pode induzir a expressão de genes responsivos a SA, induzindo resistência, ativando a proteção contra uma ampla gama de patógenos de diferentes tipos e diferentes modos de colonização (Jiang et al., 2010; Nahar et al., 2012; de Vleesschauwer et al., 2013).

Ácido jasmônico (JA) e seu derivados, comumente chamados de jasmonatos, são reguladores derivados de lipídios sintetizados a partir do ácido linoléico, e estão envolvidos em respostas de defesa e vários outros processos metabólicos. JA é um hormônio que ativa a proteção de plantas contra patógenos necrotróficos, como Rhizoctonia solani, e hemibiotróficos, como M. oryzae. Assim como SA, o aumento do nível de JA pode levar indução de resistência, chamada resistência sistêmica induzida (ISR), ativando também genes responsivos a JA, tais como genes PR, com o consequênte acúmulo de PRPs.

Quando desafiada por patógenos, as células das plantas reprogramam-se para ativar seus mecanismos de defesa. A morte celular programa nos sítios de infecção é uma resposta de defesa comum contra patógenos biotróficos e também contra insetos sugadores, que necessitam do tecido vivo para se nutrirem. Por outro lado, a morte celular é um pré-requisito para a colonização do tecido por patógenos necrotróficos, devido ao fato desses fungos se nutrirem de células mortas. Por isso mesmo é essencial que as plantas ativem o mecanismo apropriado de defesa de acordo com o tipo do patógeno. A resistência mediada por SA é efetiva contra patógenos biotróficos enquanto 
que o JA e/ou etileno (ET) medeiam respostas de defesa mais efetivas contra patógenos com estilo necrotrófico de colonização, sendo também importantes em respostas contra herbivoria (Glazebrook, 2005; Steven \& Dong, 2008). Além de elicitar vias de defesa, hormônios também interagem, apresentando efeitos regulatórios entre si, relação essa conhecida como crosstalk. O crosstalk entre SA e JA se manifesta comumente como um recíproco antagonismo, podendo ser adaptativo, dependendo das condições em que a planta se encontra; em plantas que exibem altos níveis de SA apresentam baixa quantidade de JA, bem como o acúmulo de JA induz uma queda na concentração de SA. Nessas situações, o efeito cruzado entre essas vias de sinalização constituem um dos mecanismos que permitem as plantas ajustar as suas respostas de defesa de acordo com o tipo do patógeno. Evolutivamente, alguns patógenos como M. oryzae, adquiriram a capacidade de interferir no crosstalk entre os hormônios como estratégia de virulência, alterando o balanço hormonal para seu benefício (Thaler et al., 2012).

Para alcançar níveis de resistência efetivos após o reconhecimento de $M$. oryzae, as plantas de arroz devem ajustar as diferentes vias sinalizadoras por meio das interações sinérgicas e antagônicas. O antagonismo entre SA e JA já conhecido, entretanto, não se sabe se existe interação entre as vias indutoras de ASM e de JA quando esses indutores são aplicados, qual o efeito dessa relação no desenvolvimento do patógeno na planta e no consequente controle da doença.

O objetivo desse trabalho foi determinar se existe antagonismo entre ácido jasmônico e ASM, aplicando-os nas plantas de forma conjunta e separada, e comparar as respostas de defesa que desencadeiam em plantas de arroz contra M. oryzae. 


\section{MATERIAL E MÉTODOS}

\subsection{Desenho experimental.}

O delineamento realizado foi de blocos ao acaso (DBC). Os tratamentos foram:

M. oryzae virlento - testemunha; plantas induzidas com ASM (Bion®, Syngenta Proteção de Cultivos Ltda), JA e desafiadas com M. oryzae virlento (ASM e/ou JA + VIR) e controle negativo $\left(\mathrm{H}_{2} \mathrm{O}\right)$. Foram utilizadas três bandejas por tratamento.

\subsection{Plantio cultivar BRS Primavera.}

Sementes de arroz BRS Primavera foram esterilizadas com soluções de álcool 70\% (1 min) e hipoclorito de sódio (3 min), enxaguadas em água e plantadas em bandejas com 3 $\mathrm{kg}$ de solo adubado (FTE $1 \mathrm{~g} / \mathrm{kg}$ solo, Zn $1 \mathrm{~g} / 2 \mathrm{~kg}$ e NPK - 5/30/15g/kg), e mantidas em condições de $60 \%$ de umidade e temperatura média de $25^{\circ} \mathrm{C}$ em casa de vegetação. Cada bandeja possui oito sulcos, com 10 plantas em cada.

\subsection{Aplicação das moléculas químicas de ASM e JA em plantas de arroz para} controle da brusone.

Vinte e um dias após o plantio, a ultima folha emitida até então foi induzidas com quatro soluções: ASM 0,5 mM (50\%), JA 0,25 mM, JA 0,25 mM + ASM 0,5 mM e água destilada. A suspensão de conídios à $10^{5}$ conídios.mL- ${ }^{1}$ de $M$. oryzae (PY10900) foi inoculada $48 \mathrm{~h}$ após a indução abiótica. Foram utilizadas 10 repetições por tratamento. A porcentagem de área foliar afetada pela brusone foi avaliada usando uma escala de notas (0,5 a 82\% de área foliar afetada) de acordo com Notteghem (1981). As plantas foram avaliadas durante uma semana após a inoculação de $M$. oryzae em condições de casa de vegetação

\subsection{Desafio com M. oryzae.}

O isolado virulento de $M$. oryzae 10900 proveniente da coleção de microrganismos da Embrapa Arroz e Feijão foi reativado em meio BDA (Batata-dextrose-ágar) e multiplicado em placas de Petri com meio de aveia (aveia 2\%, 1,5\% ágar, p/v), durante 10 dias a $28{ }^{\circ} \mathrm{C}$. A produção de conídios foi estimulada com a remoção do micélio aéreo da colônia de $M$. oryzae. Os conídios foram coletados com água destilada e esterilizada e 48 após, a suspensão foi ajustada a $3 \times 10^{5}$ conídios.mL $\mathrm{mL}^{-1}$ (Filippi \& Prabhu, 2001) e inoculadas em plantas 19 dias após a semeadura. A porcentagem de área foliar afetada pela brusone 
foi quantificada usando uma escala de notas (0-82\% de área foliar afetada) de acordo com Notteghem (1981). As plantas foram avaliadas durante uma semana após a inoculação de M. oryzae em condições de casa de vegetação.

\subsection{Determinação da atividade das enzimas $\beta-1,3$ glucanase, lipoxigenase,} peroxidase, fenilalanina amônia-liase, quantificação de compostos fenólicos e teor de ácido salicílico em plantas de arroz.

Plantas tratadas apenas com $M$. oryzae foram utilizadas como testemunhas e plantas tratadas com $\mathrm{H}_{2} \mathrm{O}$ como controle negativo. As coletas foram feitas em 1, 2, 3, 5, 7 e 9 DPI. Toda parte aérea da planta foi coletada, dez plantas por tratamento, e então acondicionadas em caixas de gelo e congeladas $\left(-20^{\circ} \mathrm{C}\right)$ para uso posterior.

\section{Extração de proteínas}

As amostras foram maceradas em nitrogênio líquido e em cada amostra foi adicionado solução-tampão (Tris- $\mathrm{HCl} 10$ mM; NaCl [150 mM]; EDTA [2 mM]; DTT [2 $\mathrm{mM}$ ]; PMFS [1 mM]; Leptina [10 $\left.\mu \mathrm{g} \cdot \mathrm{mL}^{-1}\right]$; Aprotinina $\left.\left[10 \mu \mathrm{g} \cdot \mathrm{mL}^{-1}\right]\right)$. Em seguida, as amostras foram agitadas num vortex durante 1 minuto e centrifugadas por 5 minutos a $10.000 \mathrm{rpm} \mathrm{a} 4^{\circ} \mathrm{C}$. O sobrenadante foi utilizado para quantificar as proteínas solúveis totais e nos ensaios de determinação de atividade enzimática. $50 \mu \mathrm{L}$ de cada amostra foram transferidos para tubos do tipo Eppendorf acrescentando $1000 \mu \mathrm{L}$ de CBB (comoassie brilliant blue). As amostras foram homogeneizadas e colocadas em repouso durante 15 minutos. Logo após, transferiu-se $100 \mu \mathrm{L}$ para placas de Elisa as quais foram colocadas em espectrofotômetro $(\lambda 597 \mathrm{~nm})$. O conteúdo de proteínas solúveis totais no extrato bruto foi medido de acordo com o método de Bradford (1976), com albumina sérica bovina (BSA) como padrão.

\section{$\beta$-1,3-Glucanase (EC 3.2.1.39) (GLU)}

Utilizou-se a metodologia descrita por Pan et al., (1991) com algumas modificações. Atividade de GLU em extrato proteico de folhas de arroz de diferentes tratamentos foram avaliados pela medição da taxa de redução da produção de açúcar utilizando laminarina como substrato. O reagente DNS (ácido dinitrosalicílico) foi usado como agente colorimétrico. A atividade foi expressa em unidades por miligrama 
de proteína $\left(\mathrm{U}_{\mathrm{mg}} \mathrm{m}^{-1}\right)$. Uma unidade foi definida como atividade enzimática catalisando a formação de açúcares redutores que aumenta a absorbância de uma unidade por hora.

Lipoxigenase (EC:1.13.11.12) (LOX)

A atividade de LOX foi determinada de acordo com Axelrod et al. (1981) usando ácido linoléico como substrato. $50 \mu \mathrm{l}$ do extrados da parte aérea de arroz foi adicionado em $2 \mathrm{~mL}$ de solução de ácido linoléico (10 mM) em tampão fosfato (50 mM, $\mathrm{pH}$ 6.0) $(0,1 \% \mathrm{v} / \mathrm{v})$, em temperatura ambiente. A atividade de LOX foi quantificada em espectrofotômetro $(\lambda=234 \mathrm{~nm})$.

Peroxidases (EC 1.11.1.7) (POX)

A atividade de peroxidase foi realizada por meio da medição do nível de oxidação de 2,2'-azino-bis-(3-etilbenzotiazolina-6-ácido sulfônico) usando suas próprias atividades colorimétricas. Uma unidade foi definida como atividade enzimática catalisando a formação de 2,2'-azino-bis-(3-etilbenzotiazolina-6-ácido sulfônico) que aumenta a absorbância de uma unidade por hora (Keesey, 1987).

\section{Fenilalanina Amônia-liase (EC 4.3.1.24) (PAL)}

A atividade de fenilalanina amônia-liase foi determinada, utilizando $2 \mathrm{ml}$ de solução de fenilalanina $10 \mathrm{mM}$, em solução tampão borato $0,1 \mathrm{M}, \mathrm{pH}$ 9,0 e $50 \mu \mathrm{l}$ de cada amostra, em triplicata. A mistura foi homogeneizada e submetida à quantificação do produto em espectrofotômetro, em comprimento de onda $290 \mathrm{~nm}$ (ultravioleta) (Côrtes et al., 2008).

\section{Compostos Fenólicos (CF)}

A quantificação de compostos fenólicos totais foi realizada segundo a metodologia de Dicko et al. (2002).A parte aérea das plantas de arroz foram coletadas para quantificação dos compostos fenólicos. O material foi imediatamente congelado em nitrogênio líquido após a coleta. As plantas foram maceradas com auxílio de cadinhos e pistilos até a obtenção de um pó fino e homogêneo. Trezentos miligramas dos compostos fenólicos solúveis foram colocados em $1500 \mu \mathrm{L}$ de metanol 70\% e, após levá-las ao sonicador por 30 minutos, as amostras foram filtradas com auxílio de algodão. O ensaio foi feito em triplicata por cada amostra onde $120 \mu \mathrm{L}$ do extrato foi misturado com $220 \mu \mathrm{L}$ de $\mathrm{H}_{2} \mathrm{O}$ milli-Q e $200 \mu \mathrm{L}$ de Folin-Ciocalteu. Após 5 min de 
incubação foi adicionado solução de $\mathrm{Na}_{2} \mathrm{CO}_{3}$ a $20 \%$ e $600 \mu \mathrm{L}$ de $\mathrm{H}_{2} \mathrm{O}$ milli-Q. A mistura foi incubada por $30 \mathrm{~min}$ a temperatura ambiente e a leitura foi feita em espectrofotômetro numa absorbância de $720 \mathrm{~nm}$.

\section{Ácido Salicílico (SA)}

Para quantificação de AS nas plantas de arroz, $200 \mathrm{mg}$ da parte aérea de cada tratamento foram maceradas e transferidas para microtubos $(2 \mathrm{~mL})$. Em cada microtubo foi adicionado $1 \mathrm{~mL}$ de metanol (90\%), seguido de agitação em agitador, por 1 minuto. As amostras foram centrifugadas, a $5000 \mathrm{rpm}$ por 10 minutos, e transferidas para um tubo falcon, de $15 \mathrm{~mL}$. Adicionou-se em cada tubo, $1 \mathrm{~mL}$ de metanol PA e $2 \mathrm{~mL}$ de ácido tricloroacético (5\%), e $2 \mathrm{~mL}$ de acetato de etila, ciclopentano e isopropanol (50:50:1). As amostras foram agitadas em agitador por 1 minuto, e o sobrenadante foi transferido para outro tubo para liofilização. Em seguida, foi adicionado em cada tubo $200 \mu \mathrm{L}$ de metanol (23\%), em tampão acetato $(20 \mu \mathrm{mol} \mathrm{pH} 5,0)$, que foram filtradas em minifiltro milipore $(0,45 \mu \mathrm{m})$. A quantificação de ácido salicílico foi realizada em um aparelho de cromatografia líquida HPLC (High Performance Liquid Chromatography) apresentando tempo de retenção de 4,8 minutos (Saikia et al., 2006; Meher et al., 2012).

\subsection{Análise estatística}

\section{Análise univariada}

Os dados de severidade de brusone foliar (SBF), GLU, PAL, LOX, POX, CF e AS foram avaliados utilizando uma análise de variância (ANOVA) e as médias foram comparadas pelo teste de Tukey $(p=0.05)$.

\section{Análise multivariada}

Análise de componentes principais (PCA) reuniu as variáveis relacionadas com as respostas de defesa da planta e severidade de doença. A PCA foi realizada utilizando os pacotes Rcmdr e FactoMineR, ambos do software 'R' 2.15 (R Development Core Team, Vienna, Austria). Essa análise foi feita utilizando tanto os efeitos multivariados das variáveis de indução de resistência (PAL, LOX, GLU, PO, AS) quanto as variáveis de doença (severidade e DPI). 


\section{RESULTADOS}

\subsection{Avaliação de severidade de brusone foliar.}

Em plantas tratadas com ASM e desafiadas com o patógeno, não se observou a formação de lesões esporulativas, mas evidenciou-se os sintomas de RH, que são pontoações castanhas que indicam morte celular, sem a presença de lesões esporulativas (Figura 1A). Quando as plantas de arroz foram tratadas com a mistura de ASM e JA, a porcentagem de área foliar afetada foi maior do que em plantas tratadas com ASM, apresentando lesões abertas com bordas marrons e centro acinzentado (indicando esporulação do fungo) (Figura 1B) e, quando comparado com a testemunha, houve redução de $44 \%$ de área foliar afetada (Tabela 1). Ao contrário de ASM, a severidade de brusone foliar $(\mathrm{SBF})$ nas plantas tratadas com JA foi muito superior em tamanho àquelas observadas nos outros tratamentos, inclusive na testemunha (Figura 1D). As lesões atingiram grande parte da extensão foliar, causando a morte de muitas das plantas avaliadas (Figura 1C), indicando que a aplicação de JA, 48 horas antes da inoculação desafiante, não elicitou a defesa da planta e induziu a suscetibilidade das plantas de arroz a M. oryzae. 

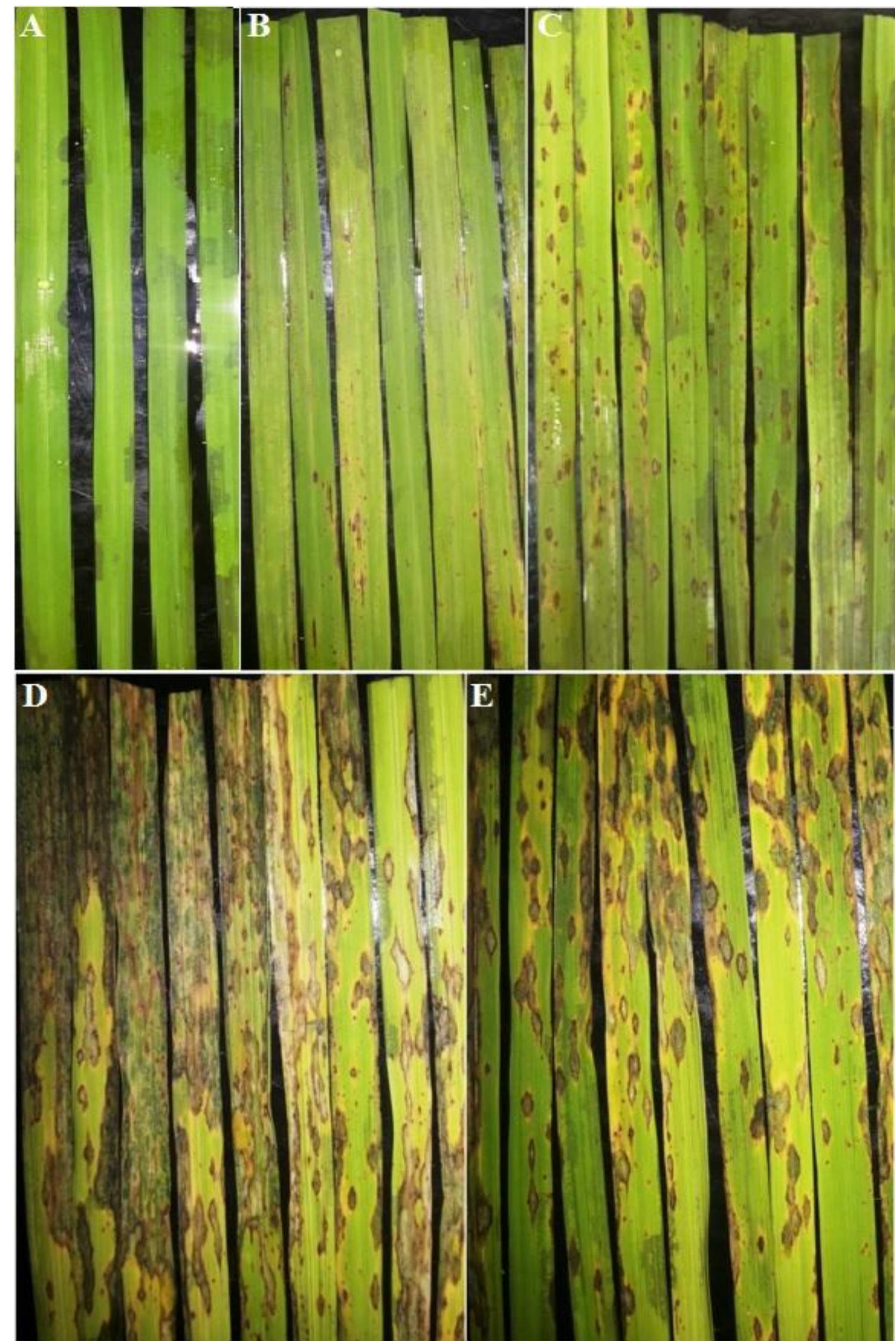

FIGURA 1- Severidade de brusone foliar em folhas de arroz. Tratamento controle $\left(\mathrm{H}_{2} \mathrm{O}\right)(\mathrm{A})$. B-E: plantas induzidas com ASM (B), induzidas com JA+ASM (C), induzidas com JA (D) e testemunha (PY10900) (E). 
3.2. Atividades das enzimas relacionadas com a defesa da planta, e quantificação dos compostos fenólicos e teores de ácido salicílico.

Plantas tratadas apenas com os agentes indutores JA, ASM e JA+ASM.

De modo geral, os valores de PRPs, compostos fenólicos (CF) e AS variaram tanto entre quanto dentro dos tratamentos. A atividade de GLU foi estimulada em todos os tratamentos nos dois primeiros dias de indução (1DPI e 2DPI), sendo maior nas plantas induzidas com os agentes indutores do que nas plantas controle $\left(\mathrm{H}_{2} \mathrm{O}\right)$. No 1DPI, seu valor foi maior em plantas tratadas com JA, seguidas de JA+ASM e ASM, em ordem decrescente. No 2DPI, somente os tratamentos JA e JA+ASM que se diferenciaram do controle. Dentre os tratamentos, apenas as plantas tratadas com JA+ASM apresentaram atividade de PAL maior do que o controle (Tabela 1). Nos dois dias subsequentes (2DPI e 3DPI), os maiores valores foram observados em plantas induzidas com ASM. Todos os tratamentos diferiram do controle no 1DPI, apresentando valores superiores. No 1DPI, a maior atividade de LOX foi observada nas plantas induzidas com JA. No 2DPI, o valor máximo de atividade de LOX foi encontrado no tratamento ASM. Já no 3DPI, o pico de atividade foi observado novamente em plantas tratadas com JA. Dentre os agentes indutores, a atividade de POX foi maior nas plantas induzidas com ASM no 1DPI e 2DPI. No 3PDI, além das plantas induzidas com ASM, a atividade de POX foi maior também em plantas tratadas com JA (Tabela 1). Os níveis de compostos fenólicos (CF) foi maior no 1DPI em plantas tratadas com JA, sendo este o único tratamento que diferiu do controle nesse primeiro tempo de avaliação. No 2DPI, todos os tratamentos diferiram do controle e o pico do teor de CF também foi maior no tratamento JA e no 3DPI, plantas induzidas com ASM mostraram os maiores valores de $\mathrm{CF}$. Os teores de SA foram maiores nos três primeiros dias naqueles tratamentos que receberam ASM tanto em forma conjunta com JA, quanto aplicado isoladamente. No 1DPI, plantas induzidas com JA+ASM apresentaram os maiores valores de SA. No 2DPI, o pico do teor foi observado em plantas tratadas com ASM e no 3DPI, em JA+ASM (Tabela 1). 
Table 1. Atividade de proteínas relacionadas à patogênese $\beta-1,3$ glucanase (GLU), fenilalanina amônia-liase (PAL), lipoxigenase (LOX), peroxidase (POX) e concentração de compostos fenólicos (CF) e de ácido salicílico (SA) e severidade de brusone foliar (SBF) em plantas de arroz de terras altas tratadas com JA, ASM, e JA+ASM seguidas ou não de inoculação desafiante com M. oryzae (PY10900).

\begin{tabular}{|c|c|c|c|c|c|c|c|c|c|c|c|c|c|c|c|c|c|}
\hline \multirow[b]{2}{*}{ Variáreis } & \multirow[b]{2}{*}{$\mathrm{DPI}^{\mathrm{a}}$} & \multicolumn{16}{|c|}{ Tratamento } \\
\hline & & JA & & $\mathrm{JA}+\mathrm{ASM}$ & & ASM & & $\mathrm{H} 2 \mathrm{O}$ & & $\begin{array}{l}\mathrm{JA}+M . \\
\text { oryzae }\end{array}$ & & $\begin{array}{c}\mathrm{JA}+\mathrm{ASM}+M \text {. } \\
\text { oryzae }\end{array}$ & & $\begin{array}{c}\mathrm{ASM}+M \\
\text { ortyzae }\end{array}$ & & M. oryzae & \\
\hline \multirow{7}{*}{$\mathrm{GLU}^{\mathrm{b}}$} & 1 & 26,65 & $\mathrm{cC}$ & 14,64 & $\mathrm{aB}$ & 11,55 & $\mathrm{aAB}$ & 9,84 & aA & & & & & & & & \\
\hline & 2 & 27,22 & cB & 29,93 & $\mathrm{~dB}$ & 18,23 & $\mathrm{cA}$ & 18,48 & bcdA & & & & & & & & \\
\hline & 3 & 27,40 & $\mathrm{cC}$ & 24,00 & $\mathrm{cBC}$ & 44,27 & $\mathrm{dD}$ & 59,29 & $\mathrm{eE}$ & 17,29 & $\mathrm{bAB}$ & 30,56 & $\mathrm{cC}$ & 16,36 & aA & 10,26 & $\mathrm{aA}$ \\
\hline & 4 & 34,76 & $\mathrm{~dB}$ & 14,07 & $\mathrm{aA}$ & 17,38 & $\mathrm{bcA}$ & 18,06 & $\mathrm{bcA}$ & 14,92 & $\mathrm{aA}$ & 16,49 & $\mathrm{aA}$ & 49,15 & $\mathrm{eC}$ & 17,50 & $\mathrm{bA}$ \\
\hline & 5 & 8,67 & $\mathrm{aA}$ & 14,56 & $\mathrm{aB}$ & 14,67 & $\mathrm{bB}$ & 22,26 & $\mathrm{cdD}$ & 18,69 & $\mathrm{bC}$ & 21,46 & $\mathrm{bD}$ & 37,84 & $\mathrm{dF}$ & 30,28 & $\mathrm{eE}$ \\
\hline & 7 & 42,99 & $\mathrm{eF}$ & 24,24 & $\mathrm{cD}$ & 10,71 & $\mathrm{aA}$ & 14,25 & $\mathrm{abB}$ & 23,02 & $\mathrm{dCD}$ & 17,24 & $\mathrm{aB}$ & 30,00 & $\mathrm{cE}$ & 20,68 & $\mathrm{cC}$ \\
\hline & 9 & 19,26 & $\mathrm{bA}$ & 20,03 & $\mathrm{bA}$ & 18,70 & $\mathrm{cA}$ & 25,09 & $\mathrm{~dB}$ & 20,92 & $\mathrm{cA}$ & 52,97 & $\mathrm{dC}$ & 25,90 & $\mathrm{bB}$ & 24,18 & $\mathrm{~dB}$ \\
\hline \multirow{7}{*}{$\mathrm{PAL}^{\mathrm{b}}$} & 1 & $1,15 \mathrm{E}-05$ & $\mathrm{cA}$ & $5,78 \mathrm{E}-05$ & $\mathrm{fC}$ & 2,19E-05 & $\mathrm{dB}$ & $2,43 \mathrm{E}-05$ & $\mathrm{eB}$ & & & & & & & & \\
\hline & 2 & $7,75 \mathrm{E}-06$ & $\mathrm{bA}$ & $6,52 \mathrm{E}-06$ & $\mathrm{bcA}$ & $2,02 \mathrm{E}-05$ & $\mathrm{cC}$ & $1,52 \mathrm{E}-05$ & $\mathrm{~dB}$ & & & & & & & & \\
\hline & 3 & $1,62 \mathrm{E}-05$ & $\mathrm{dD}$ & $7,28 \mathrm{E}-06$ & $\mathrm{cB}$ & $1,13 \mathrm{E}-05$ & $\mathrm{bC}$ & $3,27 \mathrm{E}-07$ & $\mathrm{aA}$ & $1,25 \mathrm{E}-05$ & $\mathrm{dC}$ & $5,90 \mathrm{E}-06$ & $\mathrm{aB}$ & $6,47 \mathrm{E}-06$ & $\mathrm{aB}$ & $1,24 \mathrm{E}-05$ & $\mathrm{bC}$ \\
\hline & 4 & $8,21 \mathrm{E}-06$ & $b B$ & 1,93E-06 & $\mathrm{aA}$ & $9,74 \mathrm{E}-06$ & $\mathrm{bB}$ & $1,32 \mathrm{E}-05$ & $\mathrm{cdC}$ & $6,03 \mathrm{E}-05$ & eF & $1,42 \mathrm{E}-05$ & $\mathrm{cCD}$ & $1,59 \mathrm{E}-05$ & $\mathrm{bD}$ & $3,64 \mathrm{E}-05$ & $\mathrm{cE}$ \\
\hline & 5 & $1,61 \mathrm{E}-05$ & $\mathrm{dC}$ & $1,85 \mathrm{E}-05$ & $\mathrm{eD}$ & $2,50 \mathrm{E}-05$ & $\mathrm{eE}$ & $1,15 \mathrm{E}-05$ & $\mathrm{cB}$ & 6,69E-06 & $\mathrm{cA}$ & 8,64E-06 & $\mathrm{bA}$ & $1,64 \mathrm{E}-05$ & $\mathrm{bC}$ & $1,12 \mathrm{E}-05$ & $\mathrm{cB}$ \\
\hline & 7 & $4,46 \mathrm{E}-06$ & $\mathrm{aB}$ & $1,54 \mathrm{E}-05$ & $\mathrm{dC}$ & $2,06 \mathrm{E}-05$ & $\mathrm{cdD}$ & $2,23 \mathrm{E}-05$ & $\mathrm{eD}$ & 5,59E-06 & bB & $5,86 \mathrm{E}-06$ & $\mathrm{aB}$ & $3,03 \mathrm{E}-05$ & $\mathrm{cE}$ & 2,25E-06 & $\mathrm{aA}$ \\
\hline & 9 & $2,76 \mathrm{E}-05$ & $\mathrm{eC}$ & 4,87E-06 & $\mathrm{bB}$ & 4,64E-06 & $\mathrm{aB}$ & $5,67 \mathrm{E}-06$ & $\mathrm{bB}$ & $1,57 \mathrm{E}-06$ & $\mathrm{aA}$ & 4,70E-06 & $\mathrm{aB}$ & $5,05 \mathrm{E}-06$ & $\mathrm{aB}$ & $4,45 \mathrm{E}-06$ & $\mathrm{aB}$ \\
\hline \multirow{7}{*}{$\mathrm{LOX}^{\mathrm{b}}$} & 1 & $5,72 \mathrm{E}-05$ & $\mathrm{eD}$ & $2,67 \mathrm{E}-05$ & $\mathrm{cB}$ & $3,53 \mathrm{E}-05$ & $\mathrm{cC}$ & $5,18 \mathrm{E}-06$ & $\mathrm{cA}$ & & & & & & & & \\
\hline & 2 & 4,91E-05 & $\mathrm{dC}$ & $5,42 \mathrm{E}-06$ & $\mathrm{aA}$ & $6,15 \mathrm{E}-05$ & $\mathrm{eD}$ & $1,51 \mathrm{E}-05$ & $\mathrm{fB}$ & & & & & & & & \\
\hline & 3 & 4,19E-05 & $\mathrm{cE}$ & $8,01 \mathrm{E}-06$ & $\mathrm{aBC}$ & $3,80 \mathrm{E}-06$ & aA & 7,84E-06 & $\mathrm{eB}$ & $2,65 \mathrm{E}-05$ & $\mathrm{bD}$ & $6,29 \mathrm{E}-06$ & $\mathrm{aB}$ & $1,03 \mathrm{E}-05$ & $\mathrm{bC}$ & $2,84 \mathrm{E}-05$ & $\mathrm{cD}$ \\
\hline & 4 & $2,11 \mathrm{E}-05$ & $\mathrm{aB}$ & $4,48 \mathrm{E}-05$ & $\mathrm{dD}$ & $4,23 \mathrm{E}-05$ & $\mathrm{dD}$ & $2,96 \mathrm{E}-05$ & $\mathrm{gC}$ & $4,50 \mathrm{E}-05$ & $\mathrm{cD}$ & $1,99 \mathrm{E}-05$ & $\mathrm{cB}$ & 3,29E-06 & $\mathrm{aA}$ & $3,39 \mathrm{E}-05$ & $\mathrm{dC}$ \\
\hline & 5 & 2,13E-04 & fG & 2,13E-05 & $\mathrm{bC}$ & $3,22 \mathrm{E}-05$ & $\mathrm{cD}$ & $1,10 \mathrm{E}-06$ & $\mathrm{aA}$ & $5,70 \mathrm{E}-05$ & $\mathrm{eF}$ & $1,51 \mathrm{E}-05$ & $\mathrm{bBC}$ & $9,25 \mathrm{E}-06$ & $b B$ & $4,42 \mathrm{E}-05$ & $\mathrm{eE}$ \\
\hline & 7 & $1,53 \mathrm{E}-05$ & $\mathrm{aC}$ & $6,20 \mathrm{E}-06$ & $\mathrm{aB}$ & $5,11 \mathrm{E}-07$ & aA & $6,83 \mathrm{E}-06$ & $\mathrm{~dB}$ & 1,94E-05 & $\mathrm{aD}$ & $1,48 \mathrm{E}-05$ & $\mathrm{bC}$ & 1,98E-06 & aA & $6,21 \mathrm{E}-06$ & $\mathrm{aB}$ \\
\hline & 9 & $3,38 \mathrm{E}-05$ & $\mathrm{bF}$ & $1,81 \mathrm{E}-05$ & $\mathrm{bBC}$ & $1,29 \mathrm{E}-05$ & $\mathrm{bB}$ & $2,97 \mathrm{E}-06$ & $\mathrm{bA}$ & $2,02 \mathrm{E}-05$ & $\mathrm{aCD}$ & $6,75 \mathrm{E}-06$ & $\mathrm{aA}$ & $2,72 \mathrm{E}-05$ & $\mathrm{cE}$ & $2,49 \mathrm{E}-05$ & $\mathrm{bDE}$ \\
\hline \multirow{5}{*}{$\mathrm{POX}^{\mathrm{b}}$} & 1 & 1,10 & bA & 1,08 & bA & 1,49 & $\mathrm{cdC}$ & 1,29 & $\mathrm{bB}$ & & & & & & & & \\
\hline & 2 & 1,52 & $\mathrm{cA}$ & 1,46 & $\mathrm{cA}$ & 1,78 & $\mathrm{eB}$ & 1,87 & $\mathrm{cB}$ & & & & & & & & \\
\hline & 3 & 1,36 & $\mathrm{cB}$ & 0,83 & $\mathrm{aA}$ & 1,42 & $\mathrm{cB}$ & 0,86 & $\mathrm{aA}$ & 1,55 & $a b B$ & 1,02 & $\mathrm{aA}$ & 1,92 & $\mathrm{cB}$ & 1,95 & $\mathrm{bcC}$ \\
\hline & 4 & 1,13 & $\mathrm{bBC}$ & 1,43 & $\mathrm{cDE}$ & 0,86 & $\mathrm{aA}$ & 1,25 & $\mathrm{bCD}$ & 1,57 & $a b E$ & 1,05 & $\mathrm{aB}$ & 1,59 & bEF & 1,78 & $\mathrm{cF}$ \\
\hline & 5 & 0,86 & aA & 1,21 & $\mathrm{bC}$ & 1,26 & $\mathrm{bC}$ & 1,06 & $a b B$ & 1,94 & $\mathrm{cD}$ & 1,34 & $\mathrm{bC}$ & 1,31 & $\mathrm{aC}$ & 2,06 & $c D$ \\
\hline
\end{tabular}




\begin{tabular}{|c|c|c|c|c|c|c|c|c|c|c|c|c|c|c|c|c|c|}
\hline & 7 & 0,66 & $\mathrm{aA}$ & 0,83 & $\mathrm{aAB}$ & 0,95 & $\mathrm{aB}$ & 1,02 & $a b B C$ & 1,50 & $\mathrm{aD}$ & 1,78 & $\mathrm{bE}$ & 1,17 & $\mathrm{aC}$ & 1,20 & $\mathrm{aC}$ \\
\hline & 9 & 1,46 & $\mathrm{cB}$ & 0,75 & $\mathrm{aA}$ & 1,56 & $\mathrm{~dB}$ & 1,72 & $\mathrm{cB}$ & 1,65 & $\mathrm{bB}$ & 1,38 & $\mathrm{cB}$ & 2,16 & $\mathrm{dC}$ & 2,51 & $\mathrm{dD}$ \\
\hline \multirow{7}{*}{$\mathrm{CF}^{\mathrm{c}}$} & 1 & 7,43 & $\mathrm{eC}$ & 5,60 & $\mathrm{~dB}$ & 3,96 & $\mathrm{cA}$ & 5,55 & $\mathrm{~dB}$ & & & & & & & & \\
\hline & 2 & 8,88 & $\mathrm{fC}$ & 5,86 & $\mathrm{~dB}$ & 6,13 & $\mathrm{~dB}$ & 5,14 & $\mathrm{cA}$ & & & & & & & & \\
\hline & 3 & 4,01 & $\mathrm{bB}$ & 2,63 & $\mathrm{aA}$ & 8,28 & $\mathrm{eF}$ & 5,14 & $\mathrm{cC}$ & 5,12 & $\mathrm{dC}$ & 5,69 & $\mathrm{dD}$ & 6,81 & $\mathrm{cE}$ & 11,98 & $\mathrm{eG}$ \\
\hline & 4 & 4,30 & $\mathrm{cD}$ & 7,17 & eG & 2,73 & $\mathrm{aA}$ & 4,16 & $\mathrm{bD}$ & 4,63 & $\mathrm{cE}$ & 3,41 & $\mathrm{bB}$ & 3,92 & $\mathrm{bC}$ & 6,78 & $\mathrm{cF}$ \\
\hline & 5 & 3,41 & $\mathrm{aB}$ & 9,12 & $\mathrm{fF}$ & 2,80 & $\mathrm{aA}$ & 3,45 & $\mathrm{aB}$ & 4,97 & $\mathrm{dC}$ & 7,16 & $\mathrm{eD}$ & 2,63 & $\mathrm{aA}$ & 8,45 & $\mathrm{dE}$ \\
\hline & 7 & 3,14 & $\mathrm{aB}$ & 5,09 & $\mathrm{cE}$ & 2,70 & aA & 5,28 & $\mathrm{cE}$ & 4,34 & $b D$ & 3,94 & $\mathrm{cC}$ & 7,94 & $\mathrm{dF}$ & 2,63 & $\mathrm{aA}$ \\
\hline & 9 & 5,48 & $\mathrm{dD}$ & 3,28 & $\mathrm{bB}$ & 3,38 & $\mathrm{bB}$ & 7,19 & $\mathrm{eE}$ & 2,63 & $\mathrm{aA}$ & 2,63 & $\mathrm{aA}$ & 8,64 & $\mathrm{eF}$ & 3,91 & $\mathrm{bC}$ \\
\hline \multirow{7}{*}{$\mathrm{SA}^{\mathrm{d}}$} & 1 & 807,67 & $\mathrm{bA}$ & 817,00 & $\mathrm{aB}$ & 807,00 & bA & 809,33 & $\mathrm{cA}$ & & & & & & & & \\
\hline & 2 & 835,33 & $\mathrm{~dB}$ & 860,33 & $\mathrm{cC}$ & 865,33 & $\mathrm{dD}$ & 823,33 & $\mathrm{dA}$ & & & & & & & & \\
\hline & 3 & 817,33 & $\mathrm{cA}$ & 862,00 & $\mathrm{cD}$ & 850,33 & $\mathrm{cC}$ & 826,33 & $\mathrm{deB}$ & 820,67 & bA & 889,00 & $\mathrm{cE}$ & 887,00 & $\mathrm{dE}$ & 894,00 & $\mathrm{eE}$ \\
\hline & 4 & 895,67 & $\mathrm{eB}$ & 926,00 & $\mathrm{eC}$ & 873,33 & $\mathrm{eA}$ & 895,67 & $\mathrm{fB}$ & 889,67 & $\mathrm{~dB}$ & 872,33 & $\mathrm{bA}$ & 916,33 & $\mathrm{eC}$ & 889,67 & $\mathrm{~dB}$ \\
\hline & 5 & 926,00 & $\mathrm{fE}$ & 955,33 & $\mathrm{fF}$ & 927,33 & $\mathrm{fE}$ & 832,33 & $\mathrm{eB}$ & 883,33 & $\mathrm{dC}$ & 904,33 & $\mathrm{dD}$ & 798,67 & $\mathrm{aA}$ & 798,67 & $\mathrm{cA}$ \\
\hline & 7 & 769,00 & $\mathrm{aAB}$ & 913,00 & $\mathrm{dD}$ & 929,00 & $\mathrm{fF}$ & 765,00 & $\mathrm{aA}$ & 776,00 & $\mathrm{aB}$ & 920,33 & $\mathrm{eE}$ & 826,67 & $\mathrm{cC}$ & 776,00 & $\mathrm{aB}$ \\
\hline & 9 & 807,67 & $\mathrm{bD}$ & 826,67 & $\mathrm{bE}$ & 789,67 & $\mathrm{aBC}$ & 795,33 & $\mathrm{bC}$ & 868,67 & $\mathrm{cF}$ & 762,33 & $\mathrm{aA}$ & 804,67 & $\mathrm{bD}$ & 784,00 & $\mathrm{bB}$ \\
\hline $\mathrm{SBF}^{\mathrm{e}}$ & - & - & - & - & - & - & - & - & - & 40,3125 & $\mathrm{D}$ & 12,375 & $\mathrm{~B}$ & 1,234375 & $\mathrm{~A}$ & 22,125 & $\mathrm{C}$ \\
\hline
\end{tabular}

Médias seguidas por letras minúsculas (colums) iguais não diferem estatisticamente de acordo com o teste de Tukey ( $p=0,05)$.

Médias seguidas por letras maiúsculas (rows) iguais na coluna não diferem estatisticamente de acordo com o teste de Tukey $(p=0,05)$

${ }^{\mathrm{a}} \mathrm{DPI}=$ days post induction

${ }^{\mathrm{b}}$ U.mg- ${ }^{1}$

${ }^{c} \mu \mathrm{g}$ de ácido gálico.mL de extrato ${ }^{-1}$

d ng.g- ${ }^{1}$.

${ }^{\mathrm{e}}$ Severidade de brusone foliar foi medida seguindo uma escala de notas que varia de 0,5 até $82 \%$ de área foliar afetada. 


\section{Plantas tratadas com JA, ASM e JA+ASM e desafiadas com isolado}

virulento de M. oryzae (PY10900).

Assim como na ausência do fitopatógeno, as atividades das PRPs, bem como valores de $\mathrm{CF}$ e teores de SA oscilaram entre os tratamentos e, principalmente, dentre os tratamentos (Tabela 1). A atividade de GLU foi mais intensa nas plantas que receberam a aplicação dos indutores em conjunto (JA+ASM) no primeiro dia após o desafio com o patógeno (3DPI e 9DPI). Nos quatros períodos seguintes avaliados (4DPI, 5DPI e 7DPI) os maiores valores foram encontrados nas plantas induzidas com ASM. De modo geral, a atividade de PAL foi crescente nos dois primeiros dias após o desafio (3DPI e 4DPI) em todos os tratamentos; nenhum tratamento apresentou atividade superior ou estatisticamente diferente daquela encontrada na testemunha. No 4DPI as plantas induzidas com JA foram as únicas superiores à testemunha e no 5DPI, foram as induzidas com ASM. Somente no 7DPI é que todos os outros tratamentos se diferenciaram da testemunha, onde as plantas induzidas com ASM apresentaram maiores de PAL. Os maiores valores de LOX foram observadas nas plantas induzidas apenas com JA, exceto no 5DPI. LOX apresentou um aumento contínuo do 3DPI ao 5DPI, decrescendo nos últimos períodos avaliados. Dentre os tratamentos que receberam agentes indutores, as plantas tratadas com ASM tiveram maior atividade de POX. Apenas no penúltimo período avaliado (7DPI) é que observou-se uma atividade de POX nos tratamentos induzidos (JA e JA+ASM) superior àquela registrada nas testemunhas. Os valore de CF foram maiores no 3DPI do que no 4DPI. Os valores de CF foram maiores na testemunha quase todos os tempos analisados, exceto no 7 DPI, onde as plantas induzidas tiveram maiores índices de CF, e no 9 DPI onde somente as plantas induzidas com ASM apresentaram valores superiores aos demais. De modo geral, houve um decréscimo constante na quantidade de CF nos tratamentos analisados, com exceção das plantas tratadas com ASM onde no 7DPI os valores aumentaram e no 9DPI observou-se seu pico. Na presença de $M$. oryzae, os teores de SA, no 3DPI, foi maior nas plantas induzidas com JA+ASM sem, no entanto, diferir da testemunha. Já no 4DPI, ASM apresentou o maior teor de SA e foi o único tratamento superior à testemunha. Plantas induzidas com JA+ASM apresentaram os maiores teores de SA no 5DPI e, juntamente com JA, foram os tratamentos com níveis deste hormônio maior do que os da testemunha. No 7 DPI e 9DPI, os maiores níveis de SA foram observados nos tratamentos JA+ASM e JA, respectivamente. 


\subsection{Análise de Componentes Principais (PCA).}

Os três primeiros componentes explicaram $74,13 \%$ da variância observada, com valores de 35,78\%, 21,55\% e 16,8\% para PC1, PC2 e PC3, respectivamente (Figura 2). A maioria dos resultados foram suportados principalmente pelos três primeiros componentes da PCA. As PRPs LOX, POX e GLU, juntamente com SBF mostraram grande influência na variância observada no PC1. A variância encontrada no PC2 foi influenciada principalmente pelo DPI, SA e CF. A variância encontrada no terceiro componente (PCA3) foi influenciada por PAL e também por POX, CF e SA.

Severidade de brusone foliar (SBF) foi negativamente correlacionada com GLU. Em contraste com GLU, LOX e POX por sua vez foram positivamente correlacionadas com SBF (Tabela 2). A variável DPI está correlacionada de forma negativa com CF e SA, indicando que seu valores tendem a diminuir com o passar do tempo. Os níveis de $\mathrm{CF}$ foram correlacionados positivamente com POX e claramente influenciáveis pelo hormônio SA e pela enzima PAL, ambos com valores negativos de correlação com esta primeira variável. 

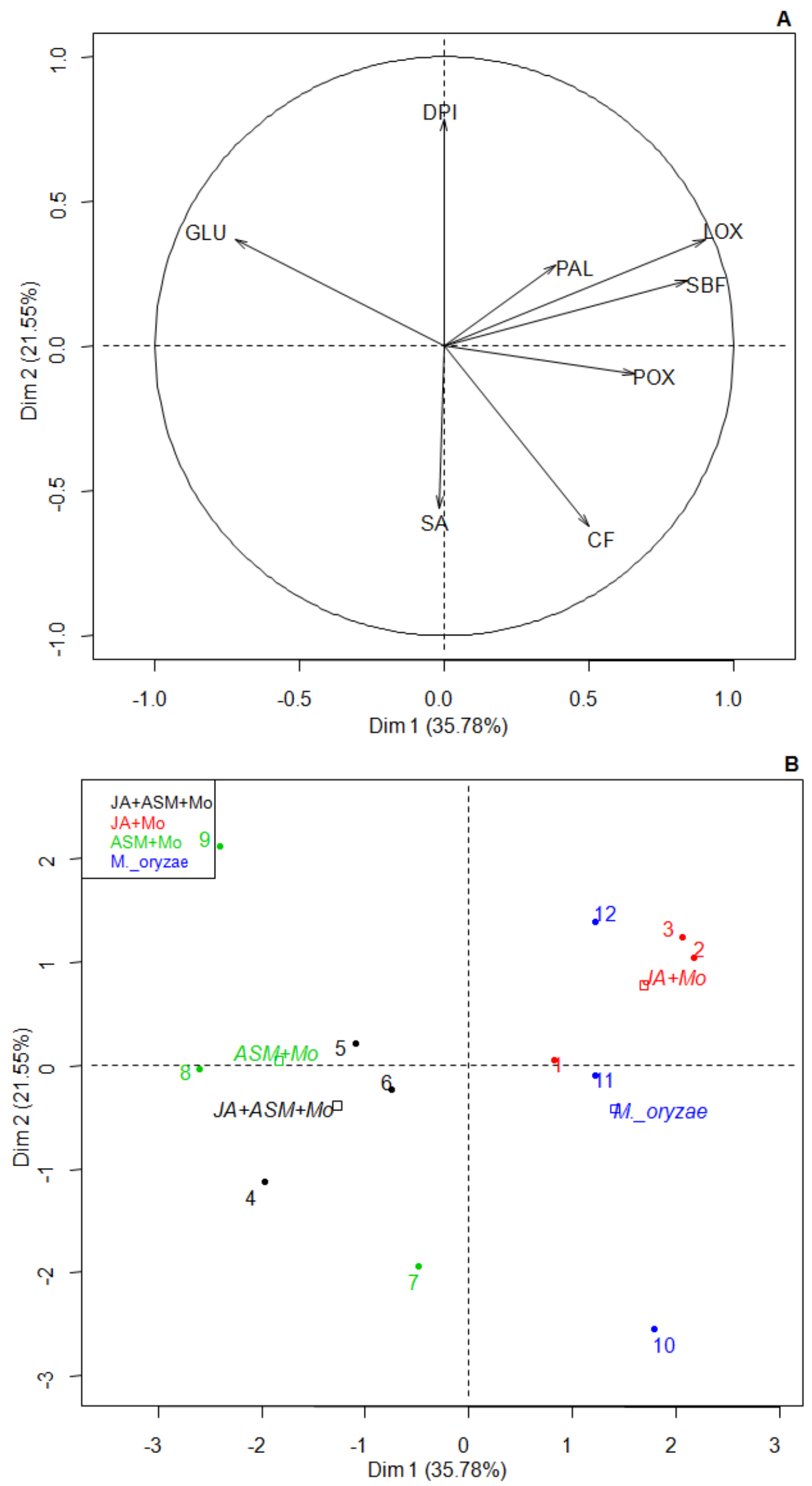
Figura 2 - PCA biplot com variaveis de investigadas na indução de resistência de plantas de arroz com JA, ASM e JA+ASM desafiadas com M. oruzae (Mo) de acordo com os dois primeiros componentes. Acorrelação entre as variáveis; B-distribuição dos dados.

Tabela 2. Matriz de correlação das variáveis relacionadas a indução de resistência em arroz para controle da brusone foliar (Magnaporthe oryzae) por JA, ASM e JA+ASM e dimenções da análise de componentes principais com significância de $p<0.05$.

\begin{tabular}{lccc}
\hline \multicolumn{1}{c}{ Variables } & PCA1 & PCA2 & PCA3 \\
\hline Rice blast severity & 0.838 & NS & NS \\
Days post induction & NS & 0.784 & NS \\
B-1,3 Glucanase & -0.723 & NS & NS \\
Peroxidase & 0.656 & NS & 0,542 \\
Phenylalanine ammonia-lyase & NS & NS & $-0,672$ \\
Lipoxygenase & 0,9 & NS & NS \\
Phenolic compounds & NS & $-0,621$ & 0,452 \\
Salicylic acid & NS & $-0,559$ & $-0,443$ \\
Explained Variance & $47,99 \%$ & $22,66 \%$ & $17,22 \%$ \\
Cumulative Variance & $47,99 \%$ & $70,65 \%$ & $87,87 \%$ \\
\hline NS
\end{tabular}

NS = not significant at $p<0,05$. 


\section{DISCUSSÃO}

Neste presente trabalho, as plantas de arroz tratadas com os agentes indutores abióticos JA e ASM apresentaram diferentes porcentagens de severidade de doença quando desafiadas por M. oryzae. A aplicação de JA tornou as plantas mais suscetíveis a infecção causada por M. oryzae. A maior área foliar afetada pela doença foi encontrada neste tratamento, inclusive maior do que na testemunha, no qual apresentou o coalecimento de lesões o que levou à morte de muitas folhas desafiadas e, eventualmente, da planta inteira (Figura 1D).

A aplicação de ASM nas plantas 48hs antes do desafio com o patógeno suprimiu a doença, com a presença de lesões de respostas de hipersensibilidade (Figura 1B) e tem demonstrado ser ativador de mecanismos de defesa, com características de indução de resistência sistêmica (Liu et al., 2008). A indução feita com a mistura dos dois compostos (JA+ASM) diminuiu a severidade da brusone foliar (Tabela 1). Apesar de não impediu o estabelecimento da infecção, com a presença de lesões abertas (Figura 1C), a área lesionada foi menor do que na testemunha (M. oryzae) (Figura 1E).

Entretanto, os resultados da SBF sugerem que há um antagonismo entre ASM e JA. O crosstalk entre JA e SA é bem documentado e comumente se manifesta como antagonismo recíproco (Thaler et al., 2012). Também há evidências que plantas de abóbora induzidas com a mistura de JA com ASM, que é análogo do SA, ficaram mais suscetíveis ao ataque de patógenos do que plantas tratadas apenas com o indutor ASM (Liu et al., 2008). A suscetibilidade de plantas ao ataque de patógenos biotróficos pode acontecer quando suas folhas são expostas ao JA (Liu et al., 2008). SA é relacionado com resistência a patógenos biotróficos e JA ativa as defesas da planta contra patógenos necrotróficos (Thaler et al., 2012). M. oryzae é um patógeno hemibiotrófico, iniciando a infecção com a forma biotrófica de colonização (Dean et al., 2012) e nessa fase da doença, o SA desempenha papel importante nas respostas de defesa. Devido ao crosstalk existente entre esses dois hormônios vegetais, a aplicação de JA aumenta a resistência contra a colonização necrotrófica, entretanto, provoca uma queda nos níveis de SA e aumenta a suscetibilidade à fase biotrófica da colonização (Robert-Seilaniantz et al., 2011).

Nos dois primeiros dias após a indução, todos os tratamentos apresentaram níveis crescentes da atividade de GLU. Já nos períodos avaliados após o desafio com $M$. oryzae, a atividade dessa enzima oscilou. A presença de acibenzolar-S-metil aumentou a 
atividade de GLU nas plantas após o desafio com o patógeno. No 3DPI e 4DPI, os maiores valores foram encontrados em plantas tratadas com JA+ASM e ASM, respectivamente. Assim como demonstrado neste trabalho, o pré-tratamento de plantas com ASM induziu a um aumento na atividade de GLU e em outras defesas das plantas, demonstrando ser efetivo na proteção contra patógenos virulentos (Niki et al., 1998; Fidantsef et al., 1999; Liu et al., 2008).

Neste estudo nós examinamos se os tratamentos influenciam na atividade de PAL. Nos dois primeiros dias de indução, plantas que receberam ASM como tratamento apresentaram maior atividade dessa enzima. Outros estudos também demonstraram a atividade indutora de ASM em plantas induzidas por aumentar a expressão de PAL em plantas tratadas (Cools \& ISHII, 2002). Na presença do patógeno, os maiores índices de PAL foram observados nas plantas que foram induzidas somente com JA nos dois primeiros dias após o desafio (3DPI e 4DPI), com valores muito superiores àqueles registrados nos tratamentos com ASM. Ao contrário do que acontece na interação muitas vezes antagônicas entre ácido jasmônico e ácido salicílico, há estudos que sugerem o papel indutor de jasmonatos na atividade de PAL (Sharan et al., 1998) indicando a existência de outra natureza de regulação entre a via dos fenilpropanóides e os jasmonatos.

Os maiores valores referentes a atividade de LOX foram observado em plantas induzidas somente com JA. Apenas no 1DPI é que todos os tratamentos tiveram uma atividade de LOX acima do nível observado no controle. A aplicação exógena de ácido jasmônico induziu a atividade de LOX. Em todos os dias avaliados, os maiores picos de atividade dessa enzima foram encontrados nas plantas induzidas com este hormônio, na presença ou na falta de $M$. oryzae (Tabela 1). JA é o produto final da via dos octadecanóides e é uma molécula sinalizadora importante para ativação de vias de defesa nas plantas da qual LOX é uma das principais enzimas envolvidas (Liu et al., 2015). Os resultados encontrados neste trabalho sugerem que JA pode estimular a atividade de LOX via mecanismo de retroalimentação. Kim et al. (2003) observaram em plântulas de milho a ativação de genes relacionados com LOX pela aplicação de metiljasmonatos. Antes do desafio, a atividade de LOX nas plantas tratadas com ASM foi maior do que no controle $\left(\mathrm{H}_{2} \mathrm{O}\right)$ no 1DPI e 2DPI e quando inoculadas, apresentaram uma baixa atividade comparada aos outros tratamentos também desafiados, não sendo superior a testemunha em nenhum dos tempos avaliados. Resultados semelhantes foram encontrados por Khalili et al. (2009) quando aplicou SA em Silybum marianum, onde a 
atividade de LOX foi maior nas primeiras horas após a indução, decrescendo nos períodos seguintes avaliados. Alguns fitopatógenos podem estimular a produção de hormônios vegetais, como etileno e JA; este último possui efeito antagônico ao SA fazendo seu nível decrescer, favorecendo assim a colonização (Pieterse et al., 2009).

A atividade de POX foi crescente em todos os tratamentos antes do desafio. A aplicação de ASM induziu um aumento na atividade dessa enzima, sendo este o único tratamento que se diferenciou do controle na ausência do patógeno e, na presença de $M$. oryzae, apresentou o maior nível de atividade de POX no dia imediato ao desafio (3DPI) (Tabela 1). A aplicação de JA e ASM em conjunto, quando comparado a outros tratamentos, mostrou-se ineficaz na indução dessa enzima. Assim como a aplicação conjunta dos agentes indutores, as plantas induzidas com JA não apresentaram um aumento na atividade de POX quando comparados ao controle. Na presença do patógeno, os níveis de POX só foram maior do que os da testemunha no 7DPI. Uma das primeiras respostas de defesa produzida pelas plantas é a explosão oxidativa, com a produção de espécies reativas de oxigênio (EROs), evento no qual POX tem papel importante (Dayme et al., 2016). Além de afetar diretamente o patógeno, EROs atua como mensageiros ativando outros mecanismos de defesa, desencadeando reações de hipersensibilidade (RH) (Liu et al., 2008; Dayme et al., 2016), como observado nas plantas induzidas com ASM (Figura 1B).

Os valores de CF variaram dependendo do(s) elicitor(es) aplicado(s). Nas plantas induzidas com JA, o nível de CF após o desafio foi crescente e maior do que o controle nos dois dias antes do desafio. Quando aplicados em conjunto, os agentes indutores não alteraram o conteúdo de CF nas plantas de arroz. Nas plantas induzidas com ASM, os valores de CF foram crescentes, mas apenas no 2DPI que diferenciaramse do controle (Tabela 1). Após o desafio, nos três primeiros dias subsequentes a inoculação, os valores de CF foram maiores na testemunha. No 3DPI, somente plantas tratadas com ASM diferiram do controle $\left(\mathrm{H}_{2} \mathrm{O}\right)$ sem, no entanto, diferir da testemunha (M. oryzae), diminuindo com o tempo. Em bananas, o nível de CF aumentou após a exposição de plantas a metil-jasmonato, com valores superiores do que em plantas induzidas com SA, apesar de este último tratamento ser superior aos controles (Ncho et $a l .$, 2016). Estes resultados sugerem que em arroz, a ação elicitora na produção de CF é relacionada ao tipo do elicitor.

As plantas tratadas com os indutores abióticos mostraram diferentes níveis de SA. Em geral, antes do desafio, as plantas apresentaram níveis crescentes de SA. Neste 
trabalho, os maiores valores de SA foram anotados nas plantas induzidas com ASM, de forma isolada ou conjunta com JA (Tabela 1). A aplicação em conjunto de JA e ASM provocou um aumento de SA no 1DPI quando comparado com o controle. No 2DPI todos os tratamentos diferiram do controle, onde o pico de SA foi observado nas plantas tratadas com ASM. Observou-se um acúmulo de SA nos dois primeiros períodos avaliados após o desafio em plantas induzidas com ASM, com valores iguais ou superiores aos da testemunha em 3DPI e 4DPI, respectivamente. A ausência do acúmulo de SA em plantas induzidas com ASM tem sido confirmada em plantas de abóbora (Orober et al., 2002) bem como em plantas de fumo (Friedrich et al., 1996) entretanto, essas plantas exibiram sinais de indução de resistência com um aumento na produção de PRPs, de uma forma não-dependente de SA. Isso sugere que em arroz, ASM pode induzir a resistência de modo similar àquele desencadeado por SA.

Três componentes da PCA foram responsáveis por 74,13\% da informação presente no conjunto das oito variáveis analisadas. A severidade de brusone foliar (SBF) e atividade de LOX foram fortemente associadas ao primeiro componente da PCA (Tabela 2) e ambas com altos valores de correlação. A maior atividade de LOX foi observada em plantas com altos índices de doença (Tabela 2). LOX são enzimas que catalisam a oxidação de ácidos graxos poliinsaturados e são uma das principais enzimas envolvidas na biossíntese de JA (Wang et al., 2008). Esse hormônio possui papel importante na defesa da planta na fase necrotófica da infecção de $M$. oryzae. Por ser um fungo hemibiotrófico, M. oryzae possui o modo biotrófico de nutrição (Vleesschauwer et al., 2013), e nesse estilo de colonização SA está associado às respostas de defesa, entretanto, JA e SA possuem uma relação antagônica. Quando níveis de JA estão altos nas etapas iniciais da infecção, a colonização dos tecidos foliares pelo patógeno é favorecida devido ao baixo teor de SA nesse período (Thaler et al., 2012). Esses resultados corroboram com aqueles encontrados no capítulo 1, onde plantas com maiores concentração de SA apresentaram menor severidade e plantas com maiores valores de LOX mostraram maiores índices de brusone. SBF também foi correlacionada com GLU. A associação dessa PRP com a severidade de doença indica a sua importância no controle da brusone foliar. Isso foi confirmado por outros trabalhos (Filippi et al., 2007; Filippi et al., 2011) e demonstrado aqui onde após o desafio com o patógeno, os tratamentos JA+ASM e principalmente ASM, plantas com maiores níveis de GLU, tiveram menor índices de SBF. GLU hidrolisa polímeros $\beta$-1,3-glucana que é um dos principais componentes da parede celular de fungos (Ferreira et al., 2007). 
Apesar de plantas tratadas com ASM mostrarem os menores índices de SBF e uma alta atividade de POX, as testemunhas e plantas induzidas com JA, que tiveram altos índices de doença, também apresentaram uma alta atividade de POX. Isso pode ser devido a presença do patógeno e o contínuo progresso da doença. Proteínas da família PR9 possuem atividade de peroxidase podem ser ativadas por indutores abiótcos como ASM (Liu et al., 2008) e também por estresses bióticos como ataque de patógenos (Daymi et al., 2016). A correlação negativa de DPI com CF e SA indica que os níveis dessas duas últimas variáveis tendem a decrescer com o tempo. SA e CF mostraram influência na variância do segundo componente, com correlação positiva entre sí. O aumento na quantidade de CF é uma resposta observada quando plantas possuem SA como elicitor. Ambos são componentes importantes em respostas de defesa de plantas onde SA atua como componente elicitor e CF são uma das respostas de defesa desencadeada por este hormônio (Misra et al., 2014). A correlação positiva entre POX e CF observada em PC3 sugere uma relação entre essas duas variáveis. Uma das primeiras respostas de defesa da planta a estresses é a produção de EROs onde POX desempenha papel primordial (Camejo et al., 2016). Dentre os mecanismos desencadeados por EROs estão a morte celular via HR e produção de CF. A produção de compostos fenólicos pode desencadear como lignificação da parede celular, estímulo da via dos fenilpropanóides, aumentando a síntese de SA e também o acúmulo de fitoalexinas (Misra et al., 2014). Essas duas características, atividade de POX e acúmulo de CF, foram observadas neste trabalho e são comumente utilizadas para identificar respostas de hipersensibilidade. PAL também foi correlacionada negativamente com os CF. Houve uma alternância entre a atividade de PAL e a quantidade de CF. Na maioria dos tratamentos, quando o valor de uma dessas variáveis estava em alta, o valor da outra estava em baixa (Tabela 1). PAL é uma enzima chave na síntese dos CF (Ferreira et al., 2007). Sua atividade decresce a medida que o substrato é consumido e o produto da reação vai sendo formado. 


\section{CONCLUSÃO}

A aplicação de acibenzolar-S-metil foi eficiente na supressão da doença; plantas com ele tratadas apresentaram RH entre 48-72hs após o desafio com o isolado PY10900.

Houve cross-talk entre JA+ASM em plantas induzidas com ambos indutores. Em plantas tratadas com JA+ASM a SBF foi maior do que nas plantas induzidas só com ASM. Entretanto, a área afetada pela doença foi menor do que aquela observada nas plantas que receberam apenas JA como indutor.

A aplicação de JA aumentou a suscetibilidade do arroz a $M$. oryzae onde a SBF de plantas por ele induzidas apresentaram maiores valores do que na testemunha.

A indução de resistência observada nas plantas pulverizadas com ASM pode estar também relacionada com a atividade de GLU, POX e concentração de SA, que foram maiores e crescentes nessas plantas.

A atividade de LOX foi estimulada pela aplicação exógena de JA e foi relacionada com alta porcentagem $\mathrm{SBF}$, sugerindo que o aumento da atividade dessa enzima nas fases iniciais da infecção não favorece a defesa da planta. A análise multivariada mostrou a importância da interação entres as respostas de defesa para o controle da doença.

Apesar de muitos autores estudarem o antagonismo entre as rotas de sinalização do SA (e análogos) e JA, este é o primeiro trabalho que registra o antagonismo entre esses dois indutores aplicados de forma exógena em arroz, avaliando suas respostas de defesa e sua consequência no controle e/ou evolução da brusone. 


\section{LITERATURA CITADA}

AXELROD, B.C.; CHEESBROUGH, T.M. \& LAASKO, S.L. 1981. Lipoxygenase from soybean. Methods in Enzymology 71:441-451.

BRADFORD, M. 1976. A rapid and sensitive method for the quantification of microgram quantities of protein utilizing the principle of protein-dye binding. Annals of Biochemistry 72:248-254.

CAMEJO, D.; GUZMÁN-CEDEÑO, A. \& MORENO, A. 2016. Reactive oxygen species, essential molecules, during plant-pathogen interactions. Plant Physiology and Biochemistry 103:10-23.

CÔRTES, M.V.C.B.; VIANA, H.F.; SILVA, F.R.; SILVA-LOBO, V.L.; SILVA, G.B.; PRABHU, A.S. \& FILIPPI, M.C.C., 2008. Quantificação da atividade enzimáticas de proteínas relacionadas à patogênese no patossistema Oryza sativa/Magnaporthe oryzae. Embrapa Arroz e Feijão, Santo Antônio de Goiás.

COOLS, H.J. \& ISHII, H. 2002. Pre-treatment of cucumber plants with acibenzolar-Smethyl systemically primes a phenylalanine ammonia lyase gene (PAL1) for enhanced expression upon attack with a pathogenic fungus. Physiological and Molecular Plant Pathology 61:273-280.

DAYMI, C.; GUZMÁN-CEDEÑO, A. \& MORENO, A. 2016. Reactive oxygen species, essential molecules, during plant-pathogen interactions. Plant Physiology and Biochemistry 103:10-23.

DEAN, R.; VAN KAN, J.A.L.; PRETORIUS, Z.A.; HAMMOND-KOSACK, K.E.; DI PIETRO, A.; SPANU, P.D.; RUDD, J.J.; DICKMAN, M.; KAHMANN, R.; ELLIS, J. \& FOSTER, G.D. 2012. The Top 10 fungal pathogens in molecular plant pathology. Molecular Plant Pathology 13:414-430.

DICKO, M.H.; HILHORST, R.; GRUPPEN, H.; TRAORE, A.S.; LAANE, C.; van BERKEL, W.J.H. \& VORAGEN, A.G.J. 2002. Comparison of content in 
phenolic compounds, polyphenoloxidase, and peroxidase in grains of fifty sorghum varietis from Burkina Faso. Journal of Agricultural and Food Chemistry 50:3780-3788.

FERREIRA, R.B.; MONTEIRO, S.; FREITAS, R.; SANTOS, C.N.; CHEN, Z.; BATISTA, L.M.; BORGES, A. \& TEIXEIRA, A.R. 2007. The role of plant defense proteins in fungal pathogenesis. Molecular Plant Pathology 8:677-700.

FIDANTSEF, A.L.; STOUT, M.J.; THALER, J.S.; DUFFEY, S.S. \& BOSTOCK, R.M. 1999. Signal interactions in pathogen and insect attack: expression of lipoxygenase, proteinase inhibitor II, and pathogenesis-related protein P4 in the tomato, Lycopersicon esculentum. Physiological and Molecular Plant Pathology 54:97-114.

FILIPPI, M.C. \& PRABHU, A.S. 2001. Phenotypic virulence analysis of Pyricularia grisea isolates from Brazilian upland rice cultivars. Pesquisa Agropecuária Brasileira 36:27-35.

FILIPPI, MARTA C.C.; SILVA, GISELE B. \& PRABHU, ANNE S. 2007. Indução de resistência à brusone em folhas de arroz por isolado avirulento de Magnaporthe oryzae. Fitopatologia Brasileira 32:387-392.

FILIPPI, M.C.C., SILVA, G.B., SILVA-LOBO, V.L., CÔRTES, M.V.C.B., MORAES, A.J.G., PRABHU, A.S., 2011. Leaf blast (Magnaporthe oryzae) suppression and growth promotion by rhizobacteria on aerobic rice in Brazil. Biological Control, 58:160-166.

FRIEDRICH, L.; LAWTON, K.; RUESS, W.; MASNER, P.; SPECKER, N.; RELLA, M.G.; MEIER, B.; DINCHER, S.; STAUB, T.; UKNES, S.; MÉTRAUX, J.P.; KESSMANN, H. \& RYALS, J. 1996. A benzothiadiazole derivative inducers systemic acquired resistance in tobacco. The Plant Journal 10:61-70.

KEESEY, J. 1987. Biochemica Information. Boehringer Manhein Biochemicals, Indianapolis. 
GLAZEBROOK, J. 2005. Contrasting mechanisms of defense against biotrophic and necrotrophic pathogens. Annual Review of Phytopathology 43:205-227.

JIANG, CJ.; SHIMONO, M.; SUGANO, S.; HOJIMA, M.; YAZAWA, K.; YOSHIDA, R.; INOUE, H.; HAYASHI, N.; SAKAKIBARA, H. TAKATSUJI, H. 2010. Abscisic acid interacts antagonistically with salicylic acid signaling pathway in rice-Magnaporthe grisea interaction. Molecular Plant Microbe Interactions 23:791-798.

KHALILI, M.; HASANLOO, T.; TABAR, S.K. \& RAHNAMA, H. 2009. Influence of exogenous salicylic acid on flavonolignans and lipoxygenase activity in hair root cultures of Silybum marianum. Cell Biology International 33:988-994.

KIM, ES.; CHOI, E.; KIM, Y.; CHO, K.; LEE, A.; SHIM, J.; RAKWAL, R.; AGRAWAL, G.K. \& HAN, O. 2003. Dual positional specificity and expression of non-traditional lipoxygenase induced by wounding and methyl jasmonate in maize seedlings. Plant Molecular Biology 52:1203-1213.

LIU, C.; RUAN, Y.; LIN, Z.; WEI, R.; PENG, Q.; GUAN, C. \& ISHII, H. 2008. Antagonism between acibenzolar- $S$-methyl-induced systemic acquired resistance and jasmonic acid-induced systemic acquired susceptibility to Colletotrichum orbiculare infection in cucumber. Physiological and Molecular Plant Pathology 72:141-145.

LIU, Z.; ZHANG, S.; SUN, N.; LIU, H.; ZHAO, Y.; LIANG, Y.; ZHANG, L. \& HAN, Y. 2015. Functional diversity of jasmonates in rice. Rice 8:5:1-13.

MISRA, N.; MISRA, R.; MARIAM, A,. YUSUF, K. \& YUSUF, L. 2014. Salicylic acid alters antioxidant and phenolics metabolism in Catharanthus roseus grown under salinity stress. African Journal of traditional, complementary, and alternative medicines: AJTCAM 11:118-25. 
MEHER, H.C.; GAJBHITE, V.T. \& SINGH, G.A. 2012. Liquid chromatography method for determination of selected amino acids, coenzymes, growth regulators, and vitamins from Cicer arietinum (L.) and Solanum lycopersicum (L.). Journal AOAC International 95:1142-1152.

NAFISI, M.; FIMOGNARI, L. \& SAKURAGI, Y. 2015. Interplays between the cell wall and phytormones in interaction between plants and necrotrophic pathogens. Phytochemistry 112:63-71.

NAHAR, K.; KYNDT, T.; NZOGELA, Y.B. \& GHEYSEN, G. 2012. Abscisic acid interacts antagonistically with classical defense pathways in rice-migratory nematode interaction. New Phytologist 196:901-913.

NCHO, X.E.; DOUMBIA, M.L.; TRAORE, S.; KONAN, Y.K.F.; KONE, M. \& KOUAKOU, T.H. 2016. Estimation of total phenolic compounds in treated leaves with methyl jasmonate and salicylic acid of banana (Musa acuminata L. AAA group cv. Grand Naine) susceptible to the Black Leaf Streak Disease. Agricultural Science Research Journal 6:175-181.

NIKI, T.; MITSUHARA, I.; SEO, S.; OHTSUBA, N. \& OHASHI, Y. 1998. Antagonistic effect of salicylic acid and jasmonic acid on the expression of pathogenesis-related (PR) protein genes in wounded mature tobacco leaves. Plant and Cell Physiology 39:500-7.

NOTTEGHEM, J.L. 1981. Cooperative experiment on horizontal resistance to rice blast. In: BLAST and upland rice: report and recommendations from the meeting for international collaboration in upland rice improvement. International Rice Research Institute, Los Baños, p.43-51.

OROBER, M.; SIEGRIST, J.; BUCHENAUER, B. \& STAUB, T. 2002. Mechanism of phosphate-induced disease resistance in cucumber. European Journal of Plant Pathology 108:345-53. 
PAN, S.Q.; YE, X.S. \& KUC, J. 1991. Association of a b-1,3-glucanase activity and isoform pattern with systemic resistance to blue mold in tobacco induced by stem injection with Peronospora tabacina or leaf inoculation with Tobacco Mosaic Virus. Physiological and Molecular Plant Pathology 39:25-39.

PIETERSE, C.M.J.; LEON-REYES, A.; VAN DER ENT, S. \& WEES, C.M.V. 2009. Networking by small-molecule hormones in plant immunity. Nature Chemical Biology 5:308-316.

ROBERT-SEILANIANTZ, A.; GRANT, M. \& JONES, J.D.G., 2011. Hormone crosstalk in plant disease and defense: more than just jasmonate-salicylate antagonism. Annual Review of Phytopathology 49:317-43.

SAIKIA, S.; PARKER, E.J.; KOULMAN, A. \& SCOTT, B. 2006. Four gene products are required for the fungal synthesis of the indole-diterpene, paspaline. FEBS Letters 580:1625-1630.

SHARAN, M.; TAGUCHI, G.; GONDA, K.; JOUKE, T.; SHIMOSAKA, M.; HAYASHIDA, N. \& OKAZAKI, M. 1998. Effects of methyl jasmonate and elicitor on the activation of phenylalanine ammonia-lyase and the accumulation of scopoletin and scopolin in tobacco cell cultures. Plant Science 132:13-19.

SPOEL, S.H. \& DONG, X. 2008. Making sense of hormone Crosstalk during plant immune responses. Cell Host and Microbes 3:347-351.

THALER, J.S.; HUMPHREY, P.T. \& WHITEMAN, N.K. 2012. Evolution of jasmonate and salicylate signal crosstalk. Trends in Plant Science 17:260-270.

De VLEESSCHAUWER, D.D.; GHEYSEN, G. \& HOFTE, M. 2013. Hormone defense networking in rice: tales from a different world. Trends in Plant Science 18:555565. 
VLOT, A.C.; DEMPSEY, D.M.A. \& KLESSING, D.F. 2009. Salicylic acid, a multifaceted hormone to combat disease. Annual Review of Phytopathology 47:177-206 


\section{CAPÍTULO 4}

promotora de crescimento Serratia sp. e isolados avirulento e virulento de Magnaporthe

oryzae. 
Comparação do trascriptoma de arroz de terras altas induzidos com rizobactéria promotora de crescimento Serratia sp. e isolados avirulento e virulento de Magnaporthe oryzae.

\section{RESUMO}

Rizobactérias promotoras de crescimento de plantas (PGPR) e fitopatógenos ativam mecanismos de defesa contra uma ampla gama de patógenos de plantas por meio da indução de resistência. Este estudo objetivou identificar alguns genes diferencialmente modulados em planta de arroz tratado com um isolado de Serratia sp., e dois isolados de Magnaporthe oryzae, um avirulento (AVR) e outro virulento (VIR), comparando as respostas de defesa desencadeados por esses agentes indutores, em buscas de novas fontes de resistência à brusone foliar. Plantas induzidas com PGPR, AVR e desafiadas com VIR tiveram seu RNA total extraído e levados a sequenciamento do transcritoma via RNAseq. A análise dos genes diferencialmente expressos (DEG) identificaram 1666, 2118 e 1600 genes modulados em respostas a PGPR, AVR e VIR, respectivamente. As rotas do ácido salicílico (SA), ácido jasmônico (JA) e etileno (ET) e genes responsivos foram ativadas em PGPR, AVR e VIR, com DEGs exclusivos em cada tratamento. Proteínas relacionadas a patogênese (PRPs) de sete atividades enzimáticas diferentes apresentaram DEG nas condições avaliadas, muitas com diferença expressiva entre os tratamentos. Um maior número de genes de fatores de transcrição da família WRKY foram encontrados em AVR e PGPR. Genes que codificam proteínas quinases ativadas por mítogeno e aqueles conhecidos com genes $\mathrm{R}$ foram DEG principalmente em AVR, entretanto, apresentaram-se genes exclusivos à cada agente indutor. Plantas em VIR apresentaram maior número de DEGs que codificam fitoalexinas. Genes que medeiam a interação entre vias hormonais também foram DE. OsNPR4 foi modulado diferencialmente em AVR e PGPR; já OsSLR1 foi responsivo apenas em VIR. Os dados de qPCR confirmaram a validade dos níveis de expressão encontrados pela técnica de RNAseq. Este é o primeiro estudo comparativo entre respostas de defesas ativadas por diferentes agentes indutores. Os resultados sugerem genes que podem ser usados como marcadores de indução bem como possíveis candidatos à fontes de resistência para melhoramento visando controle de fitodoenças do arroz.

Palavras-chave: Brusone, priming, RNA-seq, Serratia sp., sinalização hormonal. 
Comparison of the transcriptome of upland rice induced by growth promoting rhizobacterium Serratia sp. and avirulent and virulent isolates of Magnaporthe oryzae.

\section{ABSTRACT}

Plant growth-promoting rhizobacteria (PGPR) and phytopathogens can enable defense responses by inducing resistance, activating defense mechanisms against a wide range of pathogens. This study aimed to identify differentially modulated genes in rice inoculated with Serratia sp., Magnporthe oryzae avirulent (AVR) and M. oryzae virulent (VIR), comparing the defense responses triggered by these inducing agents, in search of new sources of resistance to leaf blast. Plants induced with PGPR, AVR and challenged with VIR had their total RNA extracted and led to transcriptome sequencing through RNAseq. Analysis of differentially expressed genes (DEG) identified 1666, 2118 and 1600 genes modulated in responses to PGPR, AVR and VIR, respectively. Salicylic acid (SA), jasmonic acid (JA) and ethylene (ET) and responsive genes were activated in PGPR, AVR and VIR, with DEGs unique to each treatment. Pathogenesis related proteins (PRPs) of seven different enzymatic activities had DEG under the conditions evaluated, many with great difference between treatments. A higher number of DEG WRKY transcription factors were found in AVR and PGPR. Genes that encode mitogen activated protein kinases and those known as $\mathrm{R}$ genes were mainly found in AVR, however, presented unique genes to each inducing agent. Plants challenged with VIR had higher numbers of DEGs that encode phytoalexins. Genes that mediate the interaction between hormonal pathways were also differentially expressed. OsNPR4 was differentially modulated in AVR and PGPR and OsSLR1 was responsive only in VIR. The qPCR data confirmed the validity of expression levels found by the RNAseq technique. This is the first comparative study approaching responses of defenses activated by different inducing agents. The results provide support for the importance of the activation of genes involved in the induction of resistance at initial moments of the response defense responses, highlighting genes that can serve as induction markers as well as possible candidates for resistance sources for plant breeding aimed at genetic control of diseases .

Key words: Hormonal signaling, priming, rice blast, RNA-seq, Serratia sp. 


\section{INTRODUÇÃO}

O arroz (Oryza sativa L.) é a segunda espécie de planta mais cultivada no mundo, e devido ao crescimento da população mundial, há uma necessidade do aumento de aproximadamente $40 \%$ da produção desse cereal (Khush, 2005). Além desse desafio, a orizicultura é faceada por estresses bióticos, sendo a brusone a principal doença que acomete a cultura. Esta doença, causada por Magnaporthe oryzae, é de difícil controle. O melhoramento visando resistência durável a brusone é tarefa difícil devido à alta variabilidade do patógeno, sendo necessária a busca de novas ferramentas de manejo e o melhoramento das estratégias já existentes.

Para se contra-atacarem patógenos, plantas se protegem principalmente com sistema imune de duas categorias. Servindo-se de receptores localizados nas superfícies das células, plantas reconhecem padrões moleculares associados a patógenos (PAMP) e/ou a microrganismos (MAMP). Esses receptores são moléculas estruturalmente conservadas presentes em uma ampla gama de microrganismos patogênicos, relacionados com PAMP, e benéficos, relacionados com MAMPs. Muitos desses padrões moleculares são produtos de genes housekeeping ou componentes de paredes celulares e podem induzir resistência em plantas. As respostas de defesa das plantas desencadeadas por padrões moleculares são conhecidos como imunidade desencadeada por PAMP e MAMP (PTI e MTI, respectivamente) (Schwessinger \& Zipfel, 2008; Boller \& Felix, 2009). Para que a infecção tenha sucesso, os patógenos usam efetores para suprimir as respostas de defesa ativada pelas plantas. O sistema defesa das plantas também evoluiu e possui a capacidade de detectar, direta ou indiretamente, esses efetores, colocando em ação a imunidade ativada por efetores (ETI). Vários desses elementos ativadores são comuns tanto a patógenos quanto a microrganismos benéficos, havendo semelhança também nas respostas de defesa por eles desencadeadas. ETI é constantemente acompanhada por reações de hipersensibilidade, incluindo a morte celular programada. No conjunto dessas respostas de defesa, ácido salicílico (SA) possui função importante na transdução de sinais. Outra molécula sinalizadora, etileno (ET), também está envolvido na manutenção dos reconhecimentos dos padrões moleculares na imunidade por eles ativadas (Mersmann et al., 2010). Esse sistema é efetivo contra patógenos biotróficos e hemibiotróficos, entretanto, plantas possuem sistema de defesa contra patógenos necrotróficos onde ET, juntamente com ácido jasmônico (JA), também está envolvido (Bakker et al., 2007). 
Para caracterizar respostas de plantas a determinados patógenos, a produção de hormônios e a ativação de outras componentes das respostas imunes responsivos aos hormônios podem servir como indicadores de indução de resistência. A interação entre arroz e $M$. oryzae é do tipo gene-a-gene, por isso mesmo, raças incompatíveis de $M$. oryzae podem ser usadas como ferramentas para investigar os mecanismos de resistência em arroz (Filippi et al., 2007).

A cooperação entre microrganismos benéficos como rizobactérias promotoras de crescimento (PGPR), além de resultar no aumento dos processos de crescimento, também ativa respostas de defesa das plantas. Estes fenômenos já foram estudados em arroz (Filippi et al., 2011) entretanto, pouco se sabe das mudanças envolvidas a nível molecular, especialmente em arroz de terras altas. Há trabalhos que relatam que metabólitos secundários, proteínas relacionadas à patogênese (PRP) e hormônios são mecanismos encontrados em plantas tratadas com PGPR e que essas respostas podem ser potencializadas quando as rizobactérias são utilizadas em suas cultivares de origem (Drogue et al., 2014).

A caracterização dos determinantes genéticos, semelhantes e diferentes, envolvidos na regulação das respostas de defesa induzidas por patógenos e rizobactérias fornecem elementos para compreender os mecanismos envolvidos na indução de defesa em arroz e fornecem novas possibilidades de ferramentas para controle da doença e manejo da cultura. Estudos como este permite a identificação dos principais processos biológicos e categorias funcionais de genes relacionados a defesa contra brusone do arroz, não só em interações compatíveis e incompatíveis entre $M$. oyzae e $O$. sativa mas também em plantas de arroz induzidas com PGPR. Nesse sentido, RNAseq e outras ferramentas para o estudo de expressão gênicas dão ensejo à essas oportunidades, possibilitando a identificação de genes modulados e envolvidos nos diversos processos desencadeados por esses agentes indutores.

O objetivo deste capítulo foi comparar o perfil dos transcriptomas obtidos durante a interação planta-indutor biótico/abiótico, analisando os genes modulados diferencialmente em resposta aos agentes indutores Serratia sp. e isolados avirulento e virulento de $M$. oryzae. 


\section{MATERIAL E MÉTODOS}

\subsection{Produção de suspensão da PGPR Serratia sp. BRM 32114.}

A rizobactéria utilizada neste estudo foi isolada da rizosfera de plantas de arroz provenientes de solos amazônicos, em primeiro ano de plantio de arroz, no município de Paragominas, Pará - Brasil e pertence a Coleção de Microrganismos Multifuncionais da Embrapa com o número de acesso BRM32114. Esta bactéria fora identificada como pertencente ao gênero Serratia (número de acesso no GeneBank: KX378747). A PGPR foi crescida em placas de Petri, com meio 523 (Kado \& Heskett, 1970) à $28^{\circ} \mathrm{C}$, por 24 horas. A suspensão de células bacterianas obtida foi ajustada para a uma absorbância de $550 \mathrm{~nm}$ de absorbância, correspondente a $10^{8}$ UFC. $\mathrm{mL}^{-1}$ e então aplicadas via rega em solos com plantas de arroz com 21 dias, $100 \mathrm{~mL}$ por bandeja.

Sementes da cultivar de arroz de terras altas BRS Primavera foram esterilizadas com álcool $70 \%$ e hipoclorito $2 \%$, microbiolizadas com a suspensão bacteriana (150 rpm por 24h) e secas à temperatura ambiente antes de realizar o plantio. Sementes microbiolizadas com água foram utilizadas como tratamento controle.

\subsection{Produção de inóculo do isolado avirulento de $M$. oryzae.}

O isolado avirulento de $M$. oryzae PY10749 proveniente da coleção de microrganismos da Embrapa Arroz e Feijão foi reativado em meio BDA (Batata-dextroseágar) e multiplicado em placas de Petri com meio de aveia (aveia 2\%, 1,5\% ágar, p/v), durante 10 dias a $28{ }^{\circ} \mathrm{C}$. A produção de conídios foi estimulada com a remoção do micélio aéreo da colônia de $M$. oryzae. Os conídios foram coletados com água destilada e esterilizada e 48 após, a suspensão será ajustada a $3 \times 10^{5}$ conídios.mL $\mathrm{mL}^{-1}$ (Filippi \& Prabhu, 2001) e inoculadas em plantas 21 dias após a semeadura.

\subsection{Desafio das plantas de arroz com isolado virulento de M. oryzae.}

Os isolados de $M$. oryzae foram reativados em meio BDA e multiplicado em placas de Petri contendo meio de Aveia (50g de aveia, $10 \mathrm{~g}$ dextrose, $15 \mathrm{~g}$ ágar, $1 \mathrm{~L}$ água), durante 10 dias a $28{ }^{\circ} \mathrm{C}$. A conidiogênese foi estimulada com a remoção do mícelio aéreo, feito com auxílio de um bastão de vidro e as placas expostas a luz contínua sob alta umidade, durante 48horas. Os conídios foram coletados com água destilada e 
esterilizada e a suspensão ajustada a $3 \times 10^{5}$ conídios. $\mathrm{mL}^{-1}$ seguindo o método de Filippi \& Prabhu, 2001, e inoculadas em plantas, 19 dias após a semeadura.

\subsection{Extração de RNA.}

Para análise dos transcriptomas, amostras da parte aérea das plantas induzidas com a rizobactéria BRM321144, M. oryzae VIR (PY10900), M. oryzae AVR (PY10749) foram coletadas juntamente com o controle $\left(\mathrm{H}_{2} \mathrm{O}\right)$. O experimento foi delineado em blocos ao acaso (DBC). Cada tratamento possui 3 bandejas com uma média de 80 plantas em cada. Vinte e quatro horas após a indução, coletou-se aleatóriamente das bandejas 30 plantas por tratamento. A cada dez plantas foi considerado uma réplica biológica, sendo, portanto, três réplicas por tratamento. As partes aéreas das plantas foram imediatamente congeladas em nitrogênio líquido e armazenadas em freezer $-80^{\circ} \mathrm{C}$. O RNA total foi extraído usando nitrogênio líquido. A extração de RNA foi realizada com o kit Sigma's SpectrumTM Plant Total RNA Kit seguindo as instruções do fabricante. O RNA extraído foi ressuspendido em água milli$Q$ RNase-free e armazenado a $-80^{\circ} \mathrm{C}$. A quantidade e a qualidade do RNA foi analisada por meio do NanoVue ${ }^{\mathrm{TM}}$ (GE Healthcare Life Sciences).

\subsection{Sequenciamento de RNA e análise de bioinformática.}

No total 12 amostras (três de cada tratamento) foram enviadas para sequenciamento no Centro de Genômica Funcional - Esalq (Piracicaba, SP, Brasil). As amostras foram submetidas a exame de qualidade e aquelas cujo perfil do BioAnalyser (Agilent Technologies CA, USA) com um RIN maior do que 6.5 foram sequenciadas. A plataforma utilizada foi Illumina HiSeq2500 e as reads geradas foram do tipo pairedend (PE) com tamanho de $100 \mathrm{pb}$. As análises de bioinformática foram realizadas no laboratório de enzimologia do ICB - UFG. Os arquivos FastQC foram usados para observar a qualidade das bibliotecas antes e depois da trimagem. O tratamento inicial dos dados foi feito removendo as regiões com baixa qualidade (Phred $<20$ ) e de adaptadores usando o programa Trimmomatic (versão 0.30). As reads foram filtradas e as que tinham menos de 25 nucleotídeos foram descartadas. As reads foram então alinhadas e mapeadas contra um genoma de referência de arroz (Oryza sativa ssp. japonica, Nipponbare- MSU Rice Genome version 7.0) usando o software TopHat (versão 2.0.8) em sua configuração padrão. A montagem do trascriptoma e a análise de expressão diferencial dos genes de cada biblioteca foi realizada com o software 
Cufflinks (versão 2.1.1). Os níveis de expressão foram determinados usando o software Cuffdiff dentro do Cuflinks. As reads de cada biblioteca foram normalizadas levando em consideração o tamanho dos genes, tamanho da biblioteca e o número de reads de cada gene, levando em conta a abundância de fragmentos por quilobase de exon por milhões de fragmentos mapeados. Os níveis de expressão de cada amostra foram normalizadas com a amostra do tratamento controle $\left(\mathrm{H}_{2} \mathrm{O}\right)$. Foram considerados upregulated e down-regulated os genes com valores positivos e negativos, respectivamente. Dessa forma foi possível inferir quais genes foram também diferencialmente expressos quando comparado os três tratamentos indutores entre si. Isso nos permitiu saber se houve DEGs exclusivos em algum tratamento e se estes continuariam sendo DEG mesmo quando comparado com as outras condições. Os níveis de expressão diferencial foram considerados significativos utilizando o False discovery rate (FDR) do teste de Beijamini-Hochberg $(\mathrm{P}<0.05)$.

\subsection{Validação de RNAseq pela reação em cadeia da polimerase via} transcriptase reversa quantitativa.

Vinte genes foram selecionados entre os genes diferencialmente expressos in silico para análise de expressão via RT-qPCR. O conjunto de primers foram desenhados com o sofware Primer Express Software v2.0 (Applied Biosystems) baseado nas sequências codificantes (CDS) dos genes selecionados a partir de seus transcritos. A qualidade dos primers foram avaliadas pelo programa OligoAnalyzer 3.1 (IDT Technologies). O RNA foi extraído a partir da parte aérea macerada em nitrogênio líquido usando cadinho e pistilo usando Concert ${ }^{\mathrm{TM}}$ Plant RNA Reagent (Invitrogen) de acordo com as instruções do fabricante. $500 \mu \mathrm{L}$ do reagente Concert ${ }^{\mathrm{TM}}$ Plant RNA gelado foi adicionados aos microtubos com $200 \mathrm{mg}$ do tecido macerado. A mistura foi homogeneizada em vórtex e deixada em repouso na horizontal em temperatura ambiente por $5 \mathrm{~min}$. As amostras foram centrifugadas por $5 \mathrm{~min}$ a $5^{\circ} \mathrm{C}$ a máxima velocidade. $\mathrm{O}$ sobrenadante foi transferido para novos microtubos com $100 \mu \mathrm{L}$ de $\mathrm{NaCl} 5 \mathrm{M}$ já adicionados aos tubos e então misturados por inversão. Posteriormente foram adicionados $300 \mu \mathrm{L}$ de clorofórmio gelado. Os tubos foram homogeneizados em vórtex e centrifugados por 10 min a $4{ }^{\circ} \mathrm{C}$ a $12000 \mathrm{~g}$ para separar as fases. A fase aquosa superior foi transferida para um novo tubo; o mesmo volume de isopropanol gelado foi adicionado; as amostras foram homogeneizadas e deixadas em repouso por $10 \mathrm{~min}$ a temperatura ambiente para precipitar. As amostras foram novamente centrifugadas por 
10 min a $4{ }^{\circ} \mathrm{C}$ a $12000 \mathrm{~g}$ e o sobrenadante foi então descartado. O pellet foi lavado com $1 \mathrm{~mL}$ de etanol $75 \%$ gelado e levados à centrifugação por 1 min a $12000 \mathrm{~g}$ a $4{ }^{\circ} \mathrm{C}$. O liquido residual foi removido com auxilio de pipeta e os microtubos postos a temperatura ambiente para secagem total do etanol. O RNA foi ressuspendido em $30 \mu \mathrm{L}$ de água milli- $Q$ e armazenado a $-80^{\circ} \mathrm{C}$. Para síntese de cDNA, o RNA total foi tratado com DNase I (Invitrogen ${ }^{\mathrm{TM}}$ ) para digerir o DNA presente nas amostras. Quatro microgramas de RNA de cada amostra passaram por transcrição reversa usando a trascriptase reversa Superscript II (Invitrogen ${ }^{\mathrm{TM}}$ ) seguindo as instruções do fabricante. Ao RNA foi adicionado $2 \mu \mathrm{g}$ de oligo dT, $2 \mu \mathrm{g}$ de dNTP (dATP, dCTP, dGTP e dTTP $10 \mathrm{mM}$ ) e o volume final ajustado para $24 \mu \mathrm{L}$ com $\mathrm{H}_{2} \mathrm{O}$ milli- $Q$. Os microtubos foram levados a incubação por $65{ }^{\circ} \mathrm{C}$ por cinco minutos. Em seguida, adicionou-se $8 \mu \mathrm{L}$ de tampão 5X (250 mM Tris-HCl,pH 8,3; 375 mM KCl, 15 mM MgCl 2$), 4 \mu \mathrm{L}$ de DTT 100 $\mathrm{mM}, 2 \mu \mathrm{L}$ de RNaseOUT ${ }^{\mathrm{TM}}$ e $2 \mu \mathrm{L}$ de transcriptase reversa SuperScript II. O mix foi incubado por $40{ }^{\circ} \mathrm{C}$ por $50 \mathrm{~min}$. A reação foi inativada a $70{ }^{\circ} \mathrm{C}$ por $15 \mathrm{~min}$. As amostras agora contendo cDNA foram imediatamente congeladas a $-20{ }^{\circ} \mathrm{C}$. A PCR quantitativa foi realizada utilizando o Kit Platinum $^{\circledR}$ SYBR $^{\circledR}$ Green qPCR SuperMix-UDG (Invitrogen ${ }^{\mathrm{TM}}$ ). O volume total de cada reação foi de $10 \mu \mathrm{L}$, contendo $5 \mu \mathrm{L}$ de SuperMix-UDG, $1 \mu \mathrm{L}$ de cDNA $\left(12,5 \mathrm{ng} \mathrm{x} \mu \mathrm{L}^{-1}\right)$. O volume de cada primer bem como o volume de água variou para cada gene, sendo ajustado a concentração ideal para cada oligo (Anexo tabela 1). As reações foram feitas no aparelho 7500 Real Time PCR System (Applied Biosystems ${ }^{\circledR}$ ). O programa de amplificação foi o seguinte: $50{ }^{\circ} \mathrm{C}$ por 2 minutos, $95{ }^{\circ} \mathrm{C}$ por 2 minutos, 40 ciclos de $95{ }^{\circ} \mathrm{C}$ por 15 segundos e $60{ }^{\circ} \mathrm{C}$ durante 30 segundos. Os transcritos dos genes UBQ5 e ACTIN foram usados como referências internas para normalizar o total de RNA presente em cada reação. As reações foram feitas em triplicata e a análise de expressão foi feita usando o programa DataAssit ${ }^{\mathrm{TM}}$ (Life Technologies) calculando o nível do ciclo de threshold de acordo com o método $2^{-}$ $\Delta \Delta \mathrm{CT}$. Ao final das reações foi feita uma curva de dissociação para conferir a especificidade do produto amplificado. 


\section{RESULTADOS}

\subsection{Bibliotecas de RNA-seq.}

Após a quantificação e determinação da qualidade do RNA extraído de folhas de arroz 24 horas após a indução com Serratia sp. (BRM 32114), M. oryzae avirulento (PY10749), M. oryzae virulento (PY10900) e com $\mathrm{H}_{2} \mathrm{O}$ (controle), as amostras foram submetidas ao sequenciamento de todo transcriptoma via RNA-seq. A partir do sequenciamento do trascritoma das 12 bibliotecas (três bibliotecas por tratamento), foram gerados um total de 542.562.962 de reads de 100 pb paired-ends (PE) (Tabela 1).

Para realizar as análises relativas ao trascritoma, foi utilizado o genoma de referência da espécie de arroz O. sativa japonica, versão 323_v7, ID: 29143, com tamanho de $374,471,240 \mathrm{bp}$. A cobertura total do genoma obtida por tratamento com os reads foi 60 vezes em média.

Posteriormente, as reads foram mapeadas e alinhadas por meio do software TopHat totalizaram $88,58 \%$ do número total das sequências de cada biblioteca.

\subsection{Anotação global dos genes identificados em plantas de arroz submetidas} a diferentes agentes indutores.

A análise da expressão diferencial dos transcritos relacionados com respostas de defesa desencadeadas por diferentes agentes indutores foi estimada a partir da cultivar de arroz de terras altas BRS Primavera. As reads encontrados nessa análise global do transcritoma nos auxilia a entender os mecanismos e diferenças envolvidas na indução de resistência desencadeada por diferentes agentes indutores. Foram selecionados candidatos a genes envolvidos na síntese de hormônios/moléculas elicitoras e também aqueles genes responsivos à esses fitormônios ativados pela aplicação dos indutores bióticos.

\section{Identificação dos genes diferencialmente expressos (DEGs).}

A proporção de genes diferencialmente modulados variou entre os tratamentos, com AVR apresentando maiores DEG up e down-regulated (Figura 1). Quando o tratamento indutor foi o M. oryzae avirulento (AVR), o número de DEGs foi 2118 (1627 up e 492 down-regulated), o maior dentre os tratamentos. Já quando a planta foi desafiada com M. oryzae virulento (VIR) esse número foi de 1600 (Figura 2), com 1282 up-regulated e 318 down-regulated. Em plantas induzidas com PGPR, foi encontrado 
1666 DEGs (Figura 2). Desse total, 1079 DEGs foram up-regulated e 587 downregulated (Figura 3). O diagrama de Venn (Figura 4) mostrou que dos DEGs identificados, 936 são comuns aos três tratamentos, 397, 341 e 50 DEGs foram compartilhados pelas condições AVR-VIR, AVR-PGPR e VIR-PGPR, respectivamente. O maior número de DEGs exclusivos foram encontrados em AVR (444), seguido por PGPR (339) e VIR (217).

Para investigar as funções e os papéis dos DEGs selecionados nas plantas induzidas, foi utilizado a anotação funcional dos transcritos de arroz disponibilizados por RAP-DB (http://rapdb.dna.affrc.go.jp/). Para a descrição dos genes nas sessões seguintes, o critério adotado foi baseado no papel de defesa dos genes relacionados com brusone ou em outros patossistemas, de acordo com o valor de fold changes (FC) apresentados pelos DEGs.

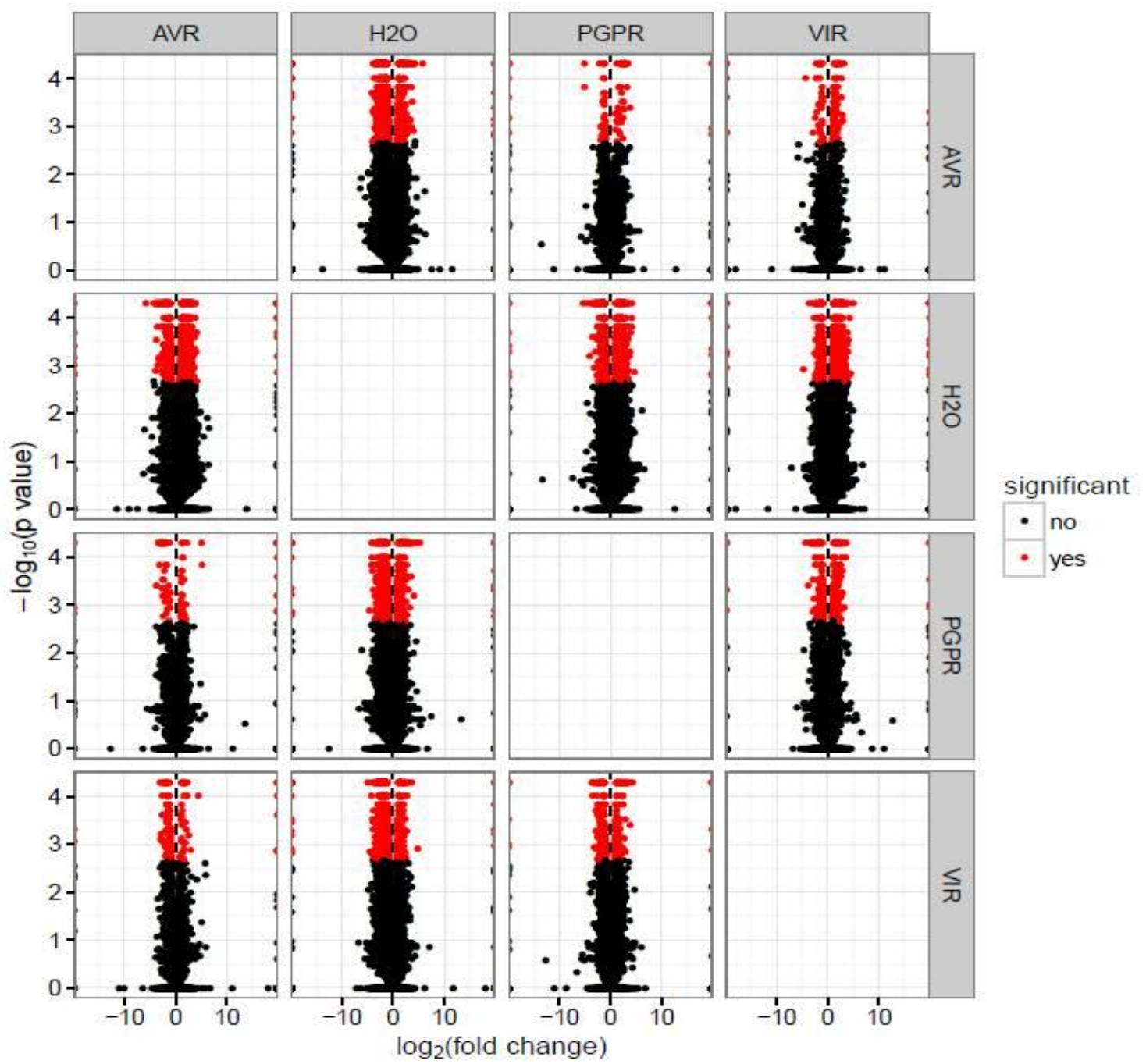

Figura 1 - Gráfico de média de expressão versus log fold change (MA-plots). Mudanças transcricionais estão presentes nas plantas de arroz após a indução. Valores de média de expressão normalizadas são plotadas contra $\log 2$ fold changes. Genes com um FDR $<0.05$ são plotados em vermelho. 


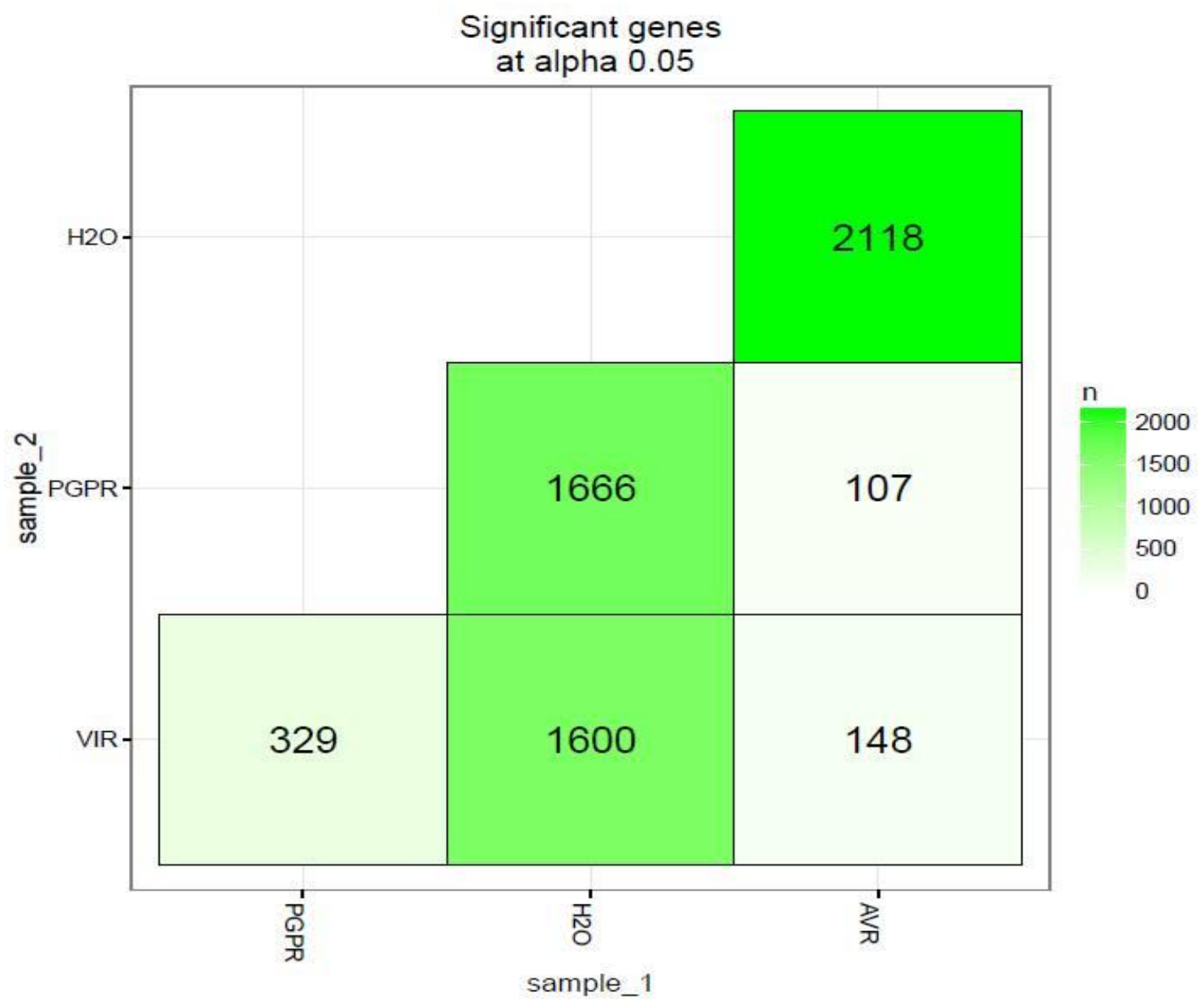

Figura 2. Diagrama de DEGs modulados pelos respectivos agentes indutores. Os DEGs encontrados 24hs após a indução.

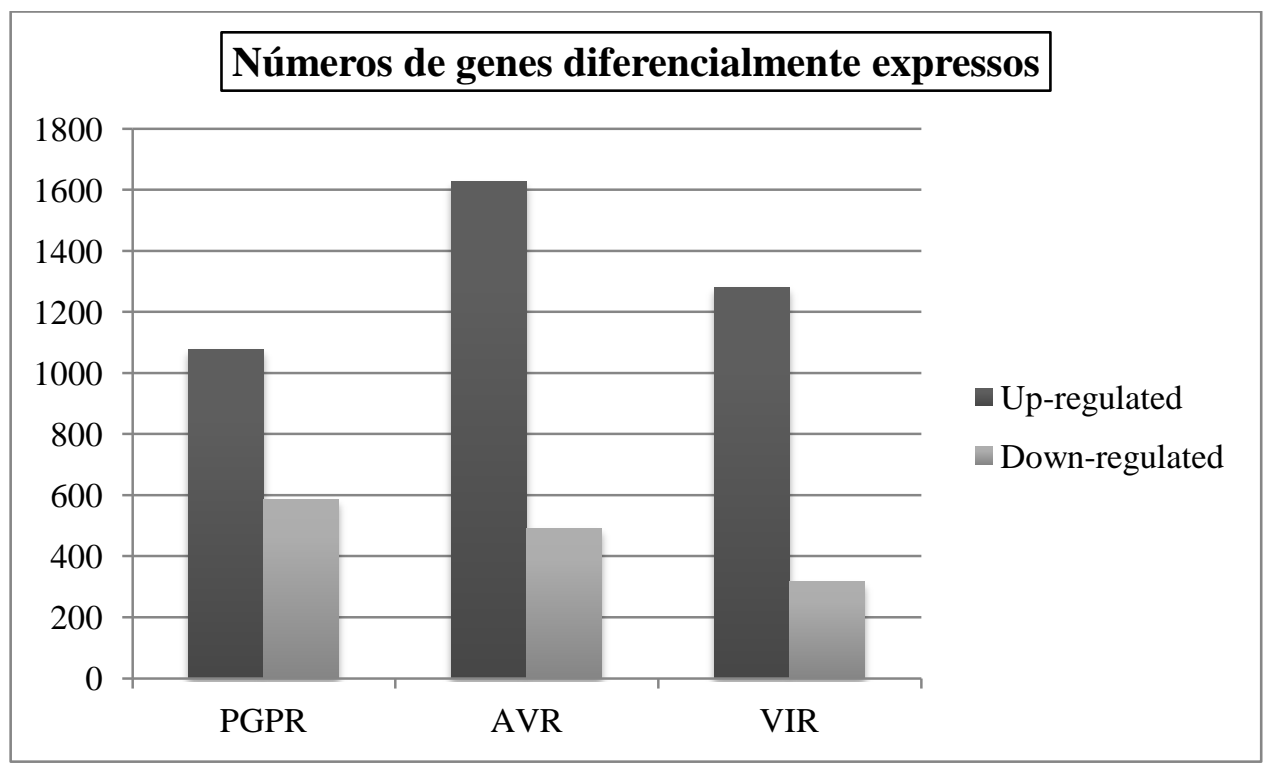

Figura 3. Mudanças no perfil de DEGs entre as três amostras. Eixo X: tratamento; eixo Y: número de genes diferencialmente expressos. 


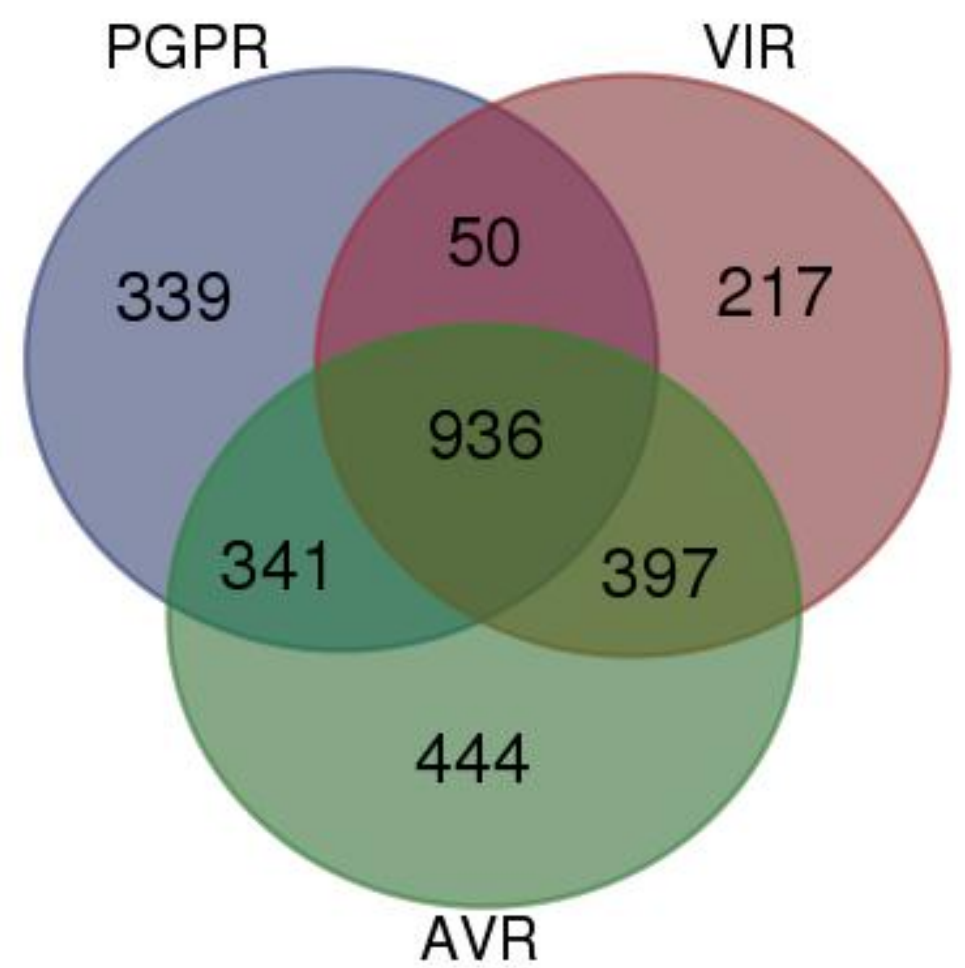

Figura 4. Diagrama de Venn ilustrando a relação entre os genes modulados nas condições PGPR, AVR e VIR.

\subsection{DEGs em plantas induzidas com Serratia sp. BRM32114.}

Três genes relacionados com via do chiquimato foram diferencialmente expressos em PGPR, todos up-regulated. Na biossíntese do triptofano foram encontrados dois DEGs: Aminodeoxi-corismato sintase (Os06g48620) e Antranilato fosforibosiltransferase (Os05g30750). Dos genes relacionados com salicilato, três foram diferencialmente modulados, todos eles com atividade de fenilalanina amônioliase (PAL), são eles: OsPAL01, OsPAL02 e OsPAL08. Desses três genes, OsPAL01 foi DEG nas plantas induzidas com a rizobactéria. OSSGT, um gene envolvido com glicosilação de SA, foi DEG e superexpresso apenas em PGPR (Figura 5; Anexo tabela 2). 

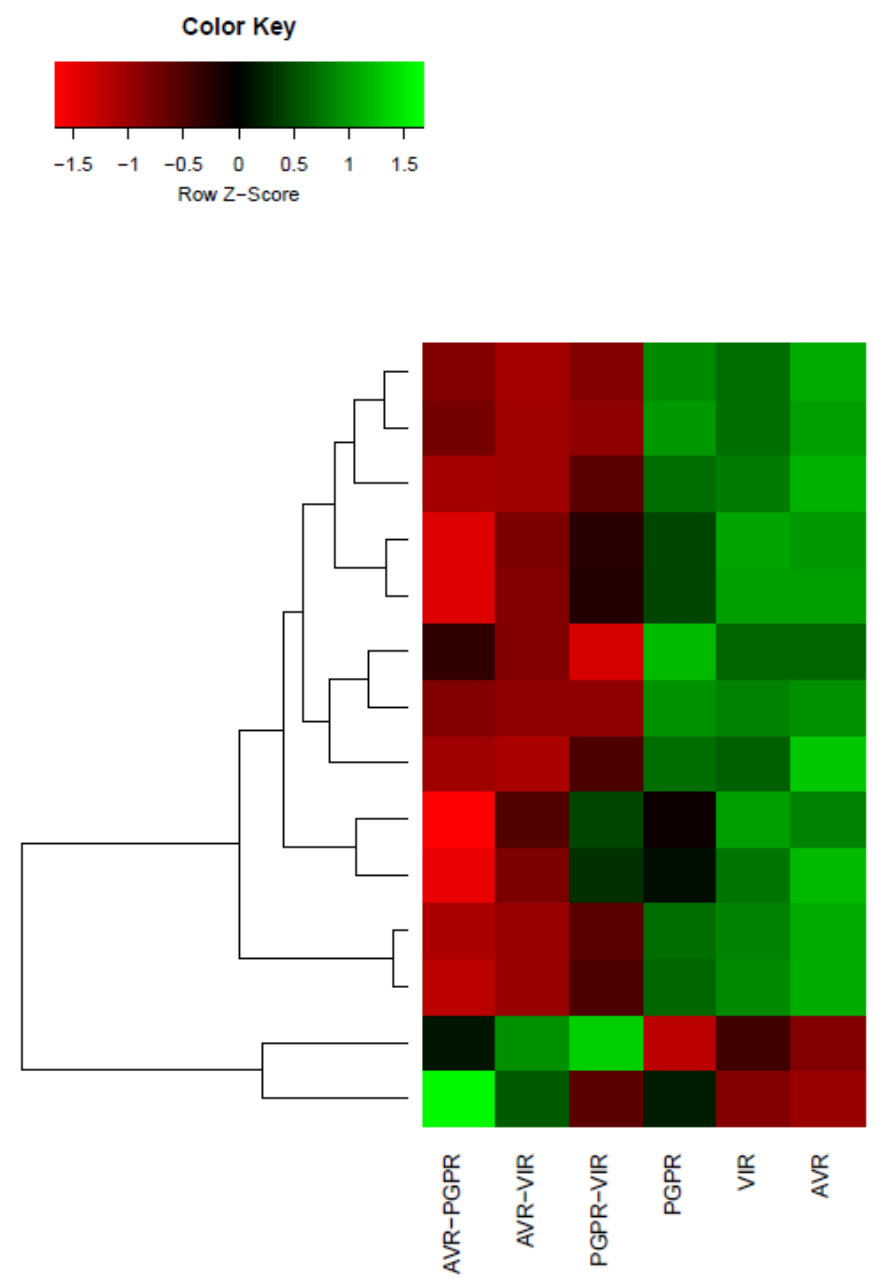

OsPAL02 Phenylalanine ammonia-lyase
OsPAL08 Phenylalanine ammonia-lyase
OsSK3 Shikimate kinase
DHQDT/SDH
OsEPSPS 5-enolpyruvylshikimate-3-phosphate synthase
OsSGT salicylic acid glucosyltransferase
OsPAL01 Phenylalanine ammonia-lyase
OsASA1 Anthranilate synthase
OsDAHP1 phospho-2-dehydro-3-deoxyheptonate aldolase
Shikimate kinase CS domain
OsDAHPS1 Chorismate biosynthesis
Anthranilate phosphoribosyltransferase
Aminodeoxychorismate synthase
Tryptophan biosynthesis Indole-3-glycerol phosphate lyase

Figura 5. Clusterização e heat map da expressão de genes da biossíntese de SA e genes responsivo a SA modulados segundo os diferentes tratamentos. A escala de cor indica o valor de expressão. O heat map foi gerado no programa R v.3.2.0 utilizando o pacote heatmap.2. Análise com distância euclidiana e usando o algorítimo UPGMA. O agrupamento do genes foi baseada na semelhança do padrão de expressão.

Oito genes que fazem parte da biossíntese do JA foram diferencialmente expressos nas plantas tratadas com a rizobactéria, onde dois foram superexpressos e seis foram reprimidos (Figura 6; Anexo tabela 3). Três genes com atividade de Lipoxigenase foram DEGs. Genes que codificam enzimas que atuam nas moléculas precursoras do metil-éster ácido jasmônico, OsAOS2 (oxidase do alene) (Os03g12500) e fosfolipases A2 (Os01g40070 e Os03g50030) foram superexpressos em PGPR. O gene oryzain beta (Os04g57440) foi DEG exclusivo dessa condição. Genes de proteínas reguladoras da ativação e biossíntese de JA como a família das proteínas JAZ (Jasmonate Zim Domain) foram reprimidos. Seis genes dessa classe foram encontrados. Vários genes ativados por JA também foram diferencialmente modulados. OsMYC2, um gene de um fator de transcrição relacionado com ativação de genes responsivos ao JA, foi reprimido nas plantas tratadas com Serratia sp. Genes relacionados com a acumulação de JA, como 
OsRERJ1 foi superexpresso. Outros genes responsivos ao JA também foram modulados (Figura 6; Anexo tabela 3). 
Tabela 1. Descrição das bibliotecas sequenciadas (RNA-seq) de plantas de arroz.

\begin{tabular}{|c|c|c|c|c|c|c|c|c|c|c|c|}
\hline Tratmento & $\begin{array}{l}\text { Reads } \\
\text { totais }\end{array}$ & $\begin{array}{l}\text { Reads } \\
\text { filtradas }\end{array}$ & $\begin{array}{l}\% \\
\text { filtradas }\end{array}$ & Mapeadas & $\begin{array}{l}\% \\
\text { mapeadas }\end{array}$ & $\begin{array}{l}\text { Reads } \\
\text { únicas }\end{array}$ & $\begin{array}{l}\text { \% reads } \\
\text { únicas }\end{array}$ & $\begin{array}{l}\text { Multi } \\
\text { reads }\end{array}$ & $\begin{array}{l}\% \text { multi } \\
\text { reads }\end{array}$ & Cobertura & Trascriptoma \\
\hline H2O_1 & 46563860 & 42447620 & 91,16001 & 37160668 & 87,54476 & 36365597 & 97,86045 & 795071 & 2,13955 & 61,67711 & 53065125 \\
\hline $\mathrm{H} 2 \mathrm{O} \_2$ & 41746416 & 37495276 & 89,81675 & 32804051 & 87,48849 & 31993749 & 97,52987 & 810302 & 2,470128 & 54,26233 & 53065125 \\
\hline H2O_3 & 44643638 & 40146602 & 89,92682 & 35488495 & 88,39726 & 34135094 & 96,18637 & 1353401 & 3,813633 & 57,89412 & 53065125 \\
\hline PGPR_1 & 46604942 & 42070598 & 90,27068 & 37738441 & 89,70265 & 34774958 & 92,14731 & 2963483 & 7,852691 & 58,97934 & 53065125 \\
\hline PGPR_2 & 42404548 & 38177556 & 90,03175 & 33956432 & 88,94344 & 33216607 & 97,82125 & 739825 & 2,178748 & 56,33633 & 53065125 \\
\hline PGPR_3 & 47092532 & 42713220 & 90,70062 & 39282066 & 91,967 & 38354981 & 97,63993 & 927085 & 2,360072 & 65,05117 & 53065125 \\
\hline AVR_1 & 40450488 & 36641020 & 90,58239 & 32514312 & 88,73746 & 31822638 & 97,87271 & 691674 & 2,127291 & 53,97212 & 53065126 \\
\hline AVR_2 & 44840962 & 40515176 & 90,35305 & 36349458 & 89,71813 & 35634144 & 98,03212 & 715314 & 1,967881 & 60,43655 & 53065127 \\
\hline AVR_3 & 42446670 & 38503816 & 90,71104 & 33709987 & 87,54973 & 32943115 & 97,72509 & 766872 & 2,27491 & 55,87248 & 53065128 \\
\hline VIR_1 & 46049680 & 41558736 & 90,24761 & 36266841 & 87,26647 & 35493040 & 97,86637 & 773801 & 2,133632 & 60,19723 & 53065129 \\
\hline VIR_2 & 46129858 & 41608946 & 90,1996 & 36879057 & 88,63252 & 36116780 & 97,93304 & 762277 & 2,066964 & 61,25511 & 53065130 \\
\hline VIR_3 & 53589368 & 48508928 & 90,51969 & 42251816 & 87,10111 & 41340798 & 97,84384 & 911018 & 2,156163 & 70,11519 & 53065131 \\
\hline TOTAL & 542562962 & 490387494 & - & 434401624 & - & 422191501 & - & 12210123 & - & 716,0491 & - \\
\hline MÉDIA & 45213580 & 40865624,5 & 90,37667 & 36200135 & 88,58742 & 35182625,1 & 97,20486 & 1017510 & 2,795139 & 59,67076 & \\
\hline
\end{tabular}




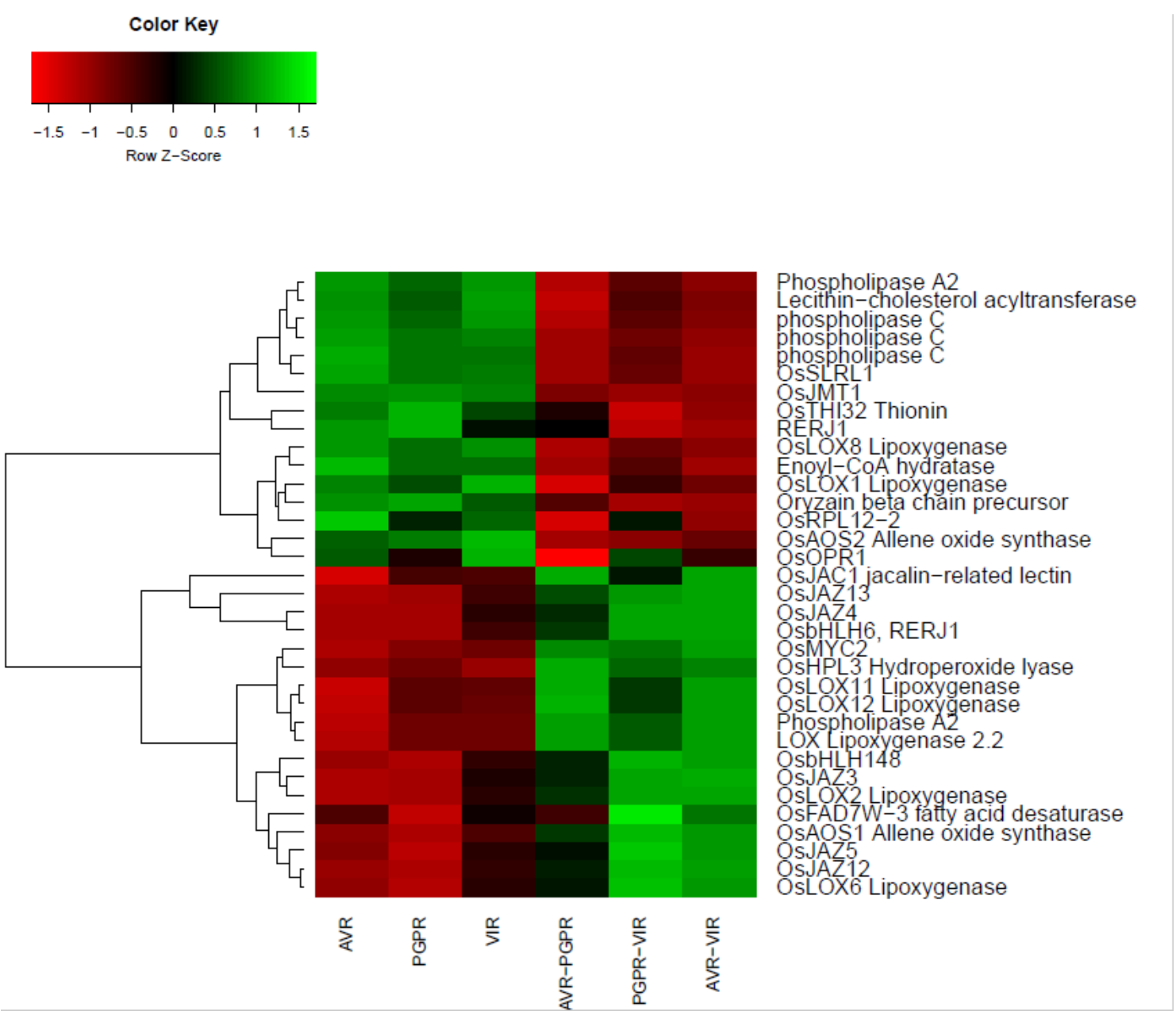

Figura 6. Clusterização e heat map da expressão de genes da biossíntese do JA e genes reponsivos a JA modulados segundo os diferentes tratamentos. A escala de cor indica o valor de expressão. O heat map foi gerado no programa R v.3.2.0 utilizando o pacote heatmap.2. Análise com distância euclidiana e usando o algorítimo UPGMA. O agrupamento do genes foi baseada na semelhança do padrão de expressão.

Três genes de arroz relacionados com a síntese de etileno foram encontrados (Anexo tabela 4), todos eles reprimidos. OsACO5 (Os05g05680) foi DEG apenas nas plantas induzidas com a rizobactéria (Figura 7; Anexo tabela 4)..OsERFs regulam a transcrição des genes envolvidos em resposta ao etileno. Três deles foram DEGs neste trabalho. OsERF1 (Os04g46220) foi superexpressos, OsERF91 e OsERF101 foram reprimidos (Figura 7; anexo tabela 4). 

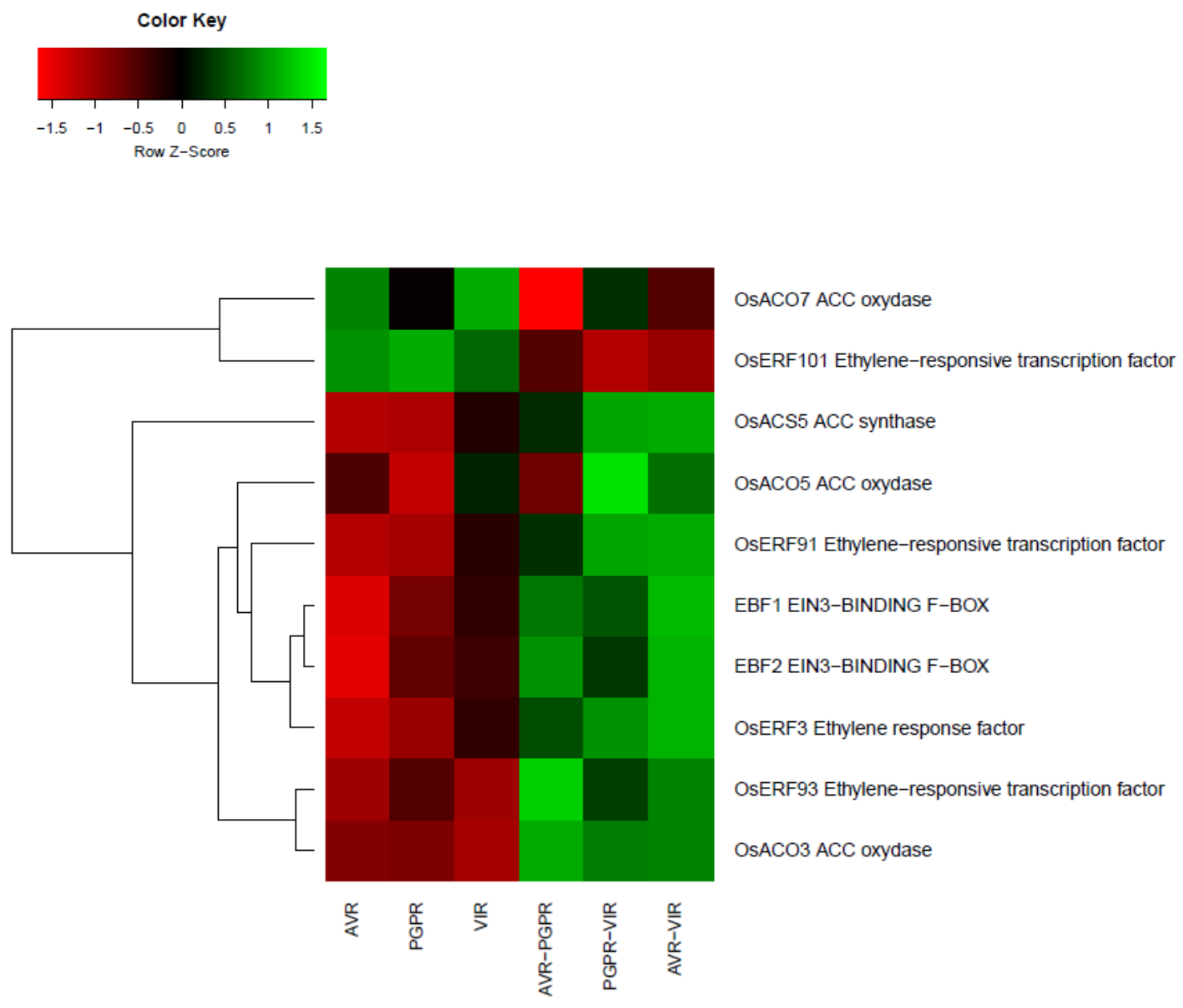

Figura 7. Clusterização e heat map da expressão de genes da biossíntese de etileno (ET) e de genes responsivos ao ET modulados segundo os diferentes tratamentos. A escala de cor indica o valor de expressão. O heat map foi gerado no programa R v.3.2.0 utilizando o pacote heatmap.2. Análise com distância euclidiana e usando o algorítimo UPGMA. O agrupamento do genes foi baseada na semelhança do padrão de expressão.

Proteínas PR (PRP) possuem atividades antimicrobianas contra uma ampla gama de fitopatógenos, sendo conhecidas dezessete famílias de PRPs. Genes relacionados a patogênese de diferentes famílias foram encontrados (Anexo tabela 5). Um gene da família proteica PR10, com atividade de ribonuclease, foi superexpresso: $O s P R 10 B$ (Os12g36850). OsPR5 (Os03g45960), pertence a família PR5, que possuem atividade de taumatina e permeabilizam a membrana fúngica, também foi superexpresso (Figura 8; anexo tabela 5). A famíla PR6, que possuem atividade inibidora de proteinase, é aqui representada pelo gene OsScil (Os12g25090), foi superexpressa e apresentou os maiores valores de FC em PGPR.

$\beta$-1,3-Glucanases (GLU) pertence a família PR2 e possuem atividade de $\beta$-1,3glucanases. Sete DEGs membros dessa família foram encontrados em planas tratadas 
com Serratia sp. Desse total, apenas dois genes foram reprimidos e cinco superexpressos, e um gene (Os03g46666) foi exclusivo dessa condição.

Quitinases (CHI) pertencem a famílias de proteínas PR PR3, 4, 8 e 11. Cinco genes foram DEGs em PGPR, sendo todos eles superexpressos. Estes genes foram modulados diferencialmente também nos outros tratamentos (Figura 8; anexo tabela 5).

PR9 são proteínas PR que possuem atividade de peroxidase (POX). Entre as proteínas PRs que tiveram o nível transcricional avaliados, POX foram as enzimas com maior quantidade de genes diferencialmente expressos: 33 no total. Vinte genes foram superexpressos. Cinco deles foram DEGs exclusivos deste tratamento, sendo 4 reprimidos (Os04g52300, Os07g47990, Os07g48010 e Os08g02110). Apenas dois genes da maquinaria celular de detoxificação de EROs, como ascorbato-peroxidase (OsAPX8) e catalase (OsCATB), foram encontrados.

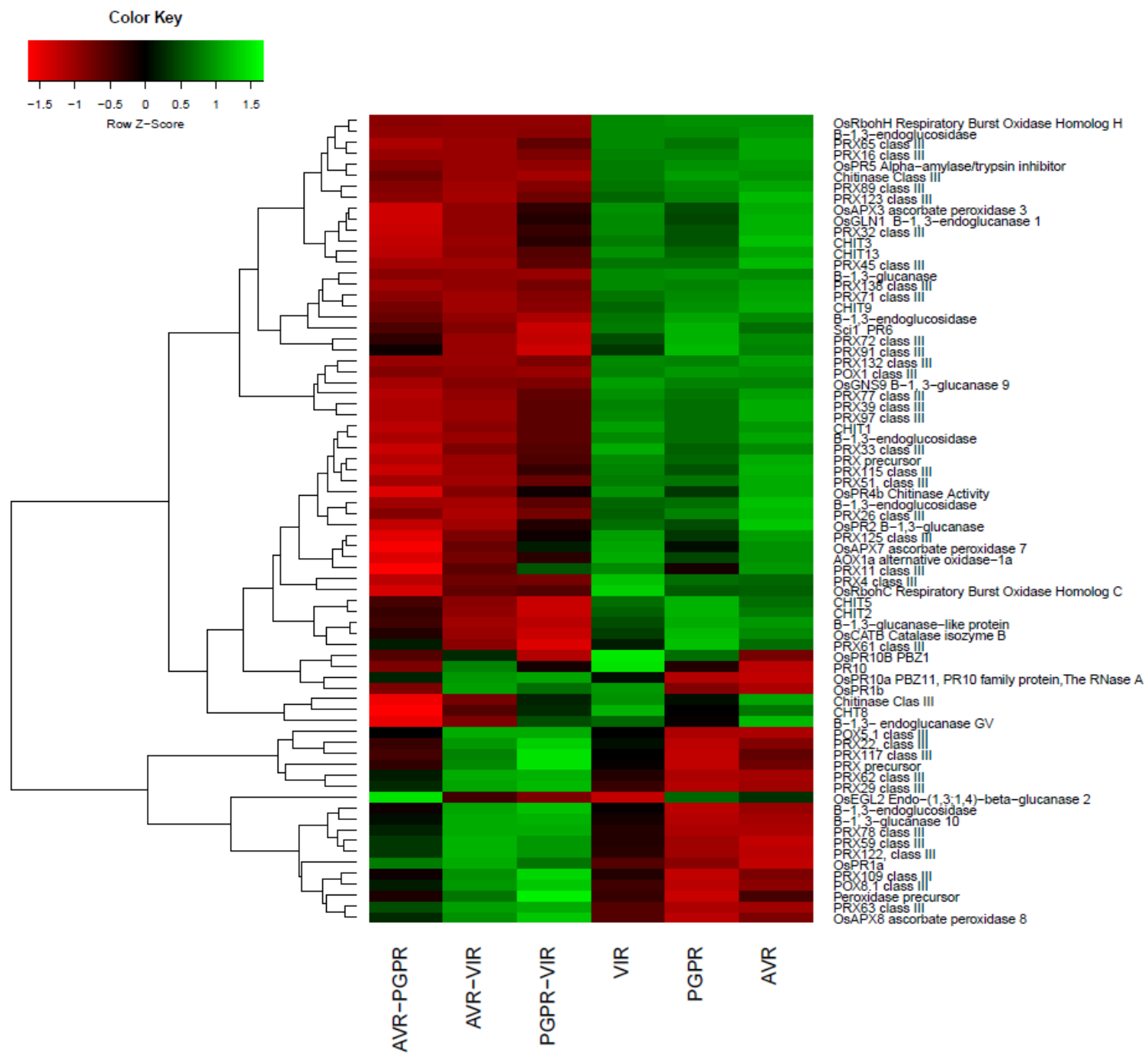

Figura 8. Clusterização e heat map da expressão de genes de proteínas relacionadas a patogênese (PRP) modulados segundo os diferentes tratamentos. A escala de cor indica o valor de expressão. $\mathrm{O}$ heat map foi gerado no programa R v.3.2.0 utilizando o pacote heatmap.2. Análise com distância euclidiana e usando o algorítimo UPGMA. O agrupamento do genes foi baseada na semelhança do padrão de expressão. 
WRKY são fatores de transcrição relacionados a respostas de defesa. Em plantas tratadas com Serratia sp., dez genes foram diferencialmente expressos: oito reprimidos (WRKY 4, 18, 22, 46, 63, 69, 60 e 61) e dois superexpressos (WRKY 17 e 31). OsWRKY69 foi diferencialmente expresso apenas em PGPR (Figura 9; anexo tabela 6).

Color Key
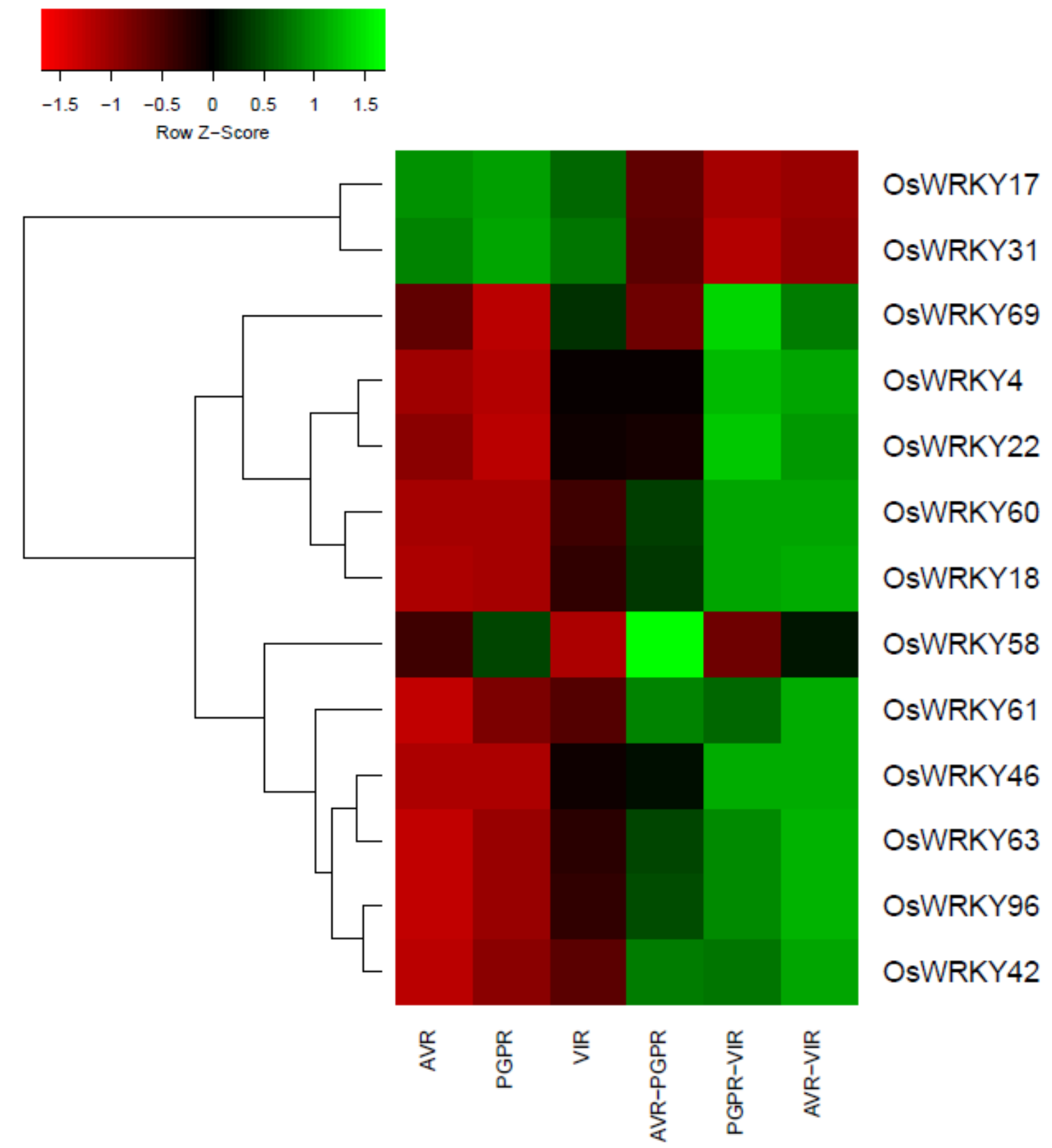

Figura 9. Clusterização e heat map da expressão de genes fatores de trasncrição WRKY modulados segundo os diferentes tratamentos. A escala de cor indica o valor de expressão. O heat map foi gerado no programa R v.3.2.0 utilizando o pacote heatmap.2. Análise com distância euclidiana e usando o algorítimo UPGMA. O agrupamento do genes foi baseada na semelhança do padrão de expressão.

Nove genes de proteínas quinases ativadas por mitógenos (MAPK, MAPKK e $M A P K K K$ ) foram identificados como diferencialmente expressos, três superexpressos e 
seis com FC negativo. Os genes que foram DEGs e superexpressos são: MAPK10 (Os01g43910), MAPKKK30 (Os02g02780) e MAPKKK74 (Os01g66860) (Figura 10; anexo tabela 7).

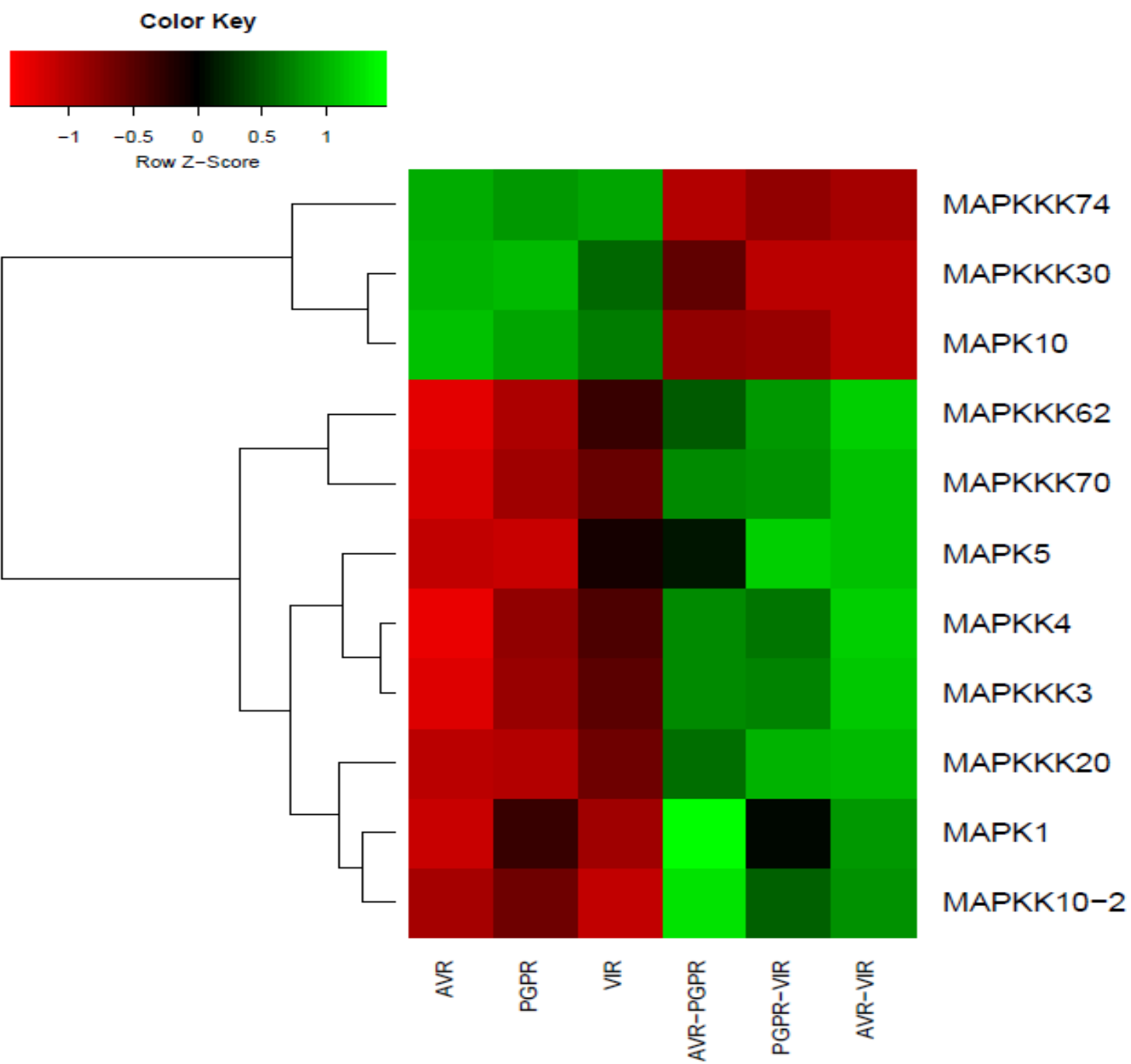

Figura 10. Clusterização e heat map da expressão de genes MAP quinases modulados segundo os diferentes tratamentos. A escala de cor indica o valor de expressão. $\mathrm{O}$ heat map foi gerado no programa $\mathrm{R}$ v.3.2.0 utilizando o pacote heatmap.2. Análise com distância euclidiana e usando o algorítimo UPGMA. $\mathrm{O}$ agrupamento do genes foi baseada na semelhança do padrão de expressão.

Em plantas de arroz induzidas com Serratia sp. sete genes relacionados com fitoalexinas foram superexpressos (Anexo tabela 9). Destes, dois genes relacionados são relacionados com maaquiaina (Os01g01650 e Os01g660), uma fitoalexina do grupo dos isoflavonoides. Dois genes são relacionados com fitocassano e três com momilactonas, duas das fitoalexinas sintetizadas a partir da via metabólica dos fenilpropanoides (Figura 11; anexo tabela 9). 


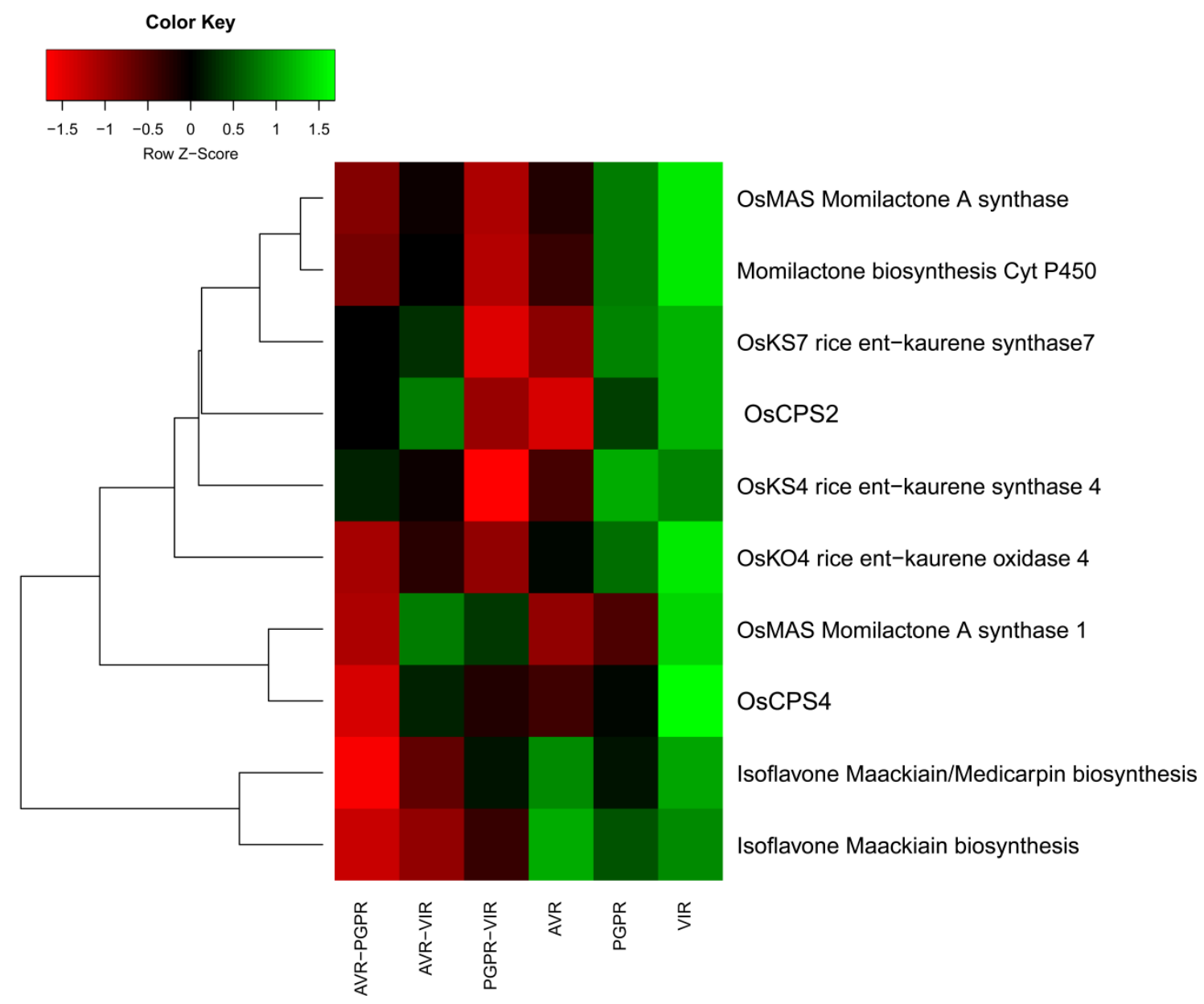

Figura 11. Clusterização e heat map da expressão de genes da biossíntese de fitoalexinas modulados segundo os diferentes tratamentos. A escala de cor indica o valor de expressão. O heat map foi gerado no programa R v.3.2.0 utilizando o pacote heatmap.2. Análise com distância euclidiana e usando o algorítimo UPGMA. O agrupamento do genes foi baseada na semelhança do padrão de expressão.

P450s é um grupo de enzimas do grupo das monoxigenases envolvidas na catálise da oxidação de diversos substratos por meio da ativação do oxigênio molecular. Elas estão envolvidas no processo metabólico de várias vias de sinalização relacionadas com respostas de defesa da planta, como hormônios vegetais, fitoalexinas e lignina. Vinte e oito genes foram diferencialmente expressos nessa condição, sendo 11 reprimidos e 17 superexpressos. (Anexo tabela 10; Figura 12). Dois desses genes P450, localizados no cromosso 7 (LOC_OS07g23570 e LOC_OS07g44140), são relacionados com respostas de defesa mas sem função definida, foram superexpressos nas três condições avaliadas. 


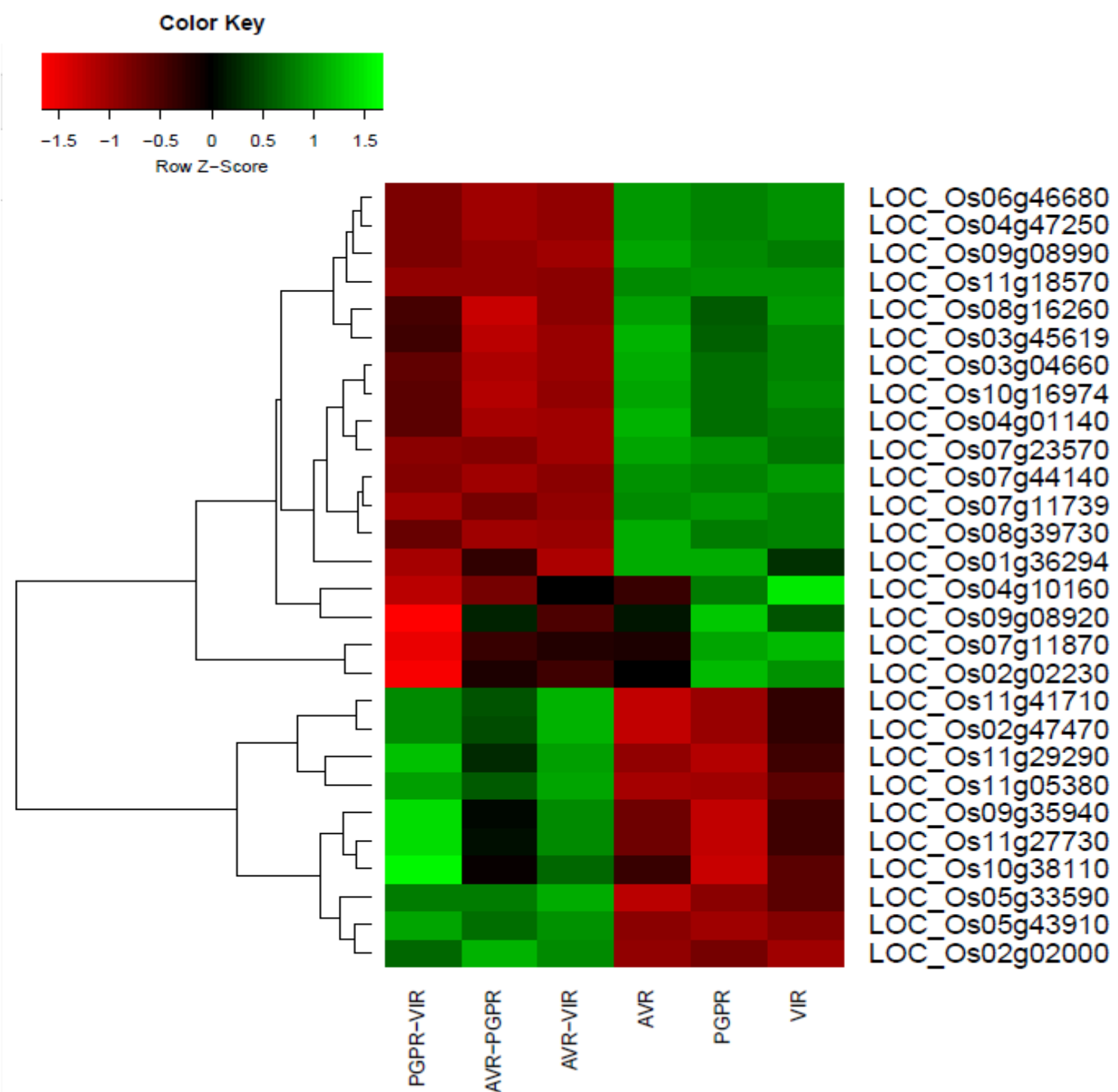

Figura 12. Clusterização e heat map da expressão de genes do citocromo $\mathrm{P} 450$ modulados segundo os diferentes tratamentos. A escala de cor indica o valor de expressão. O heat map foi gerado no programa $\mathrm{R}$ v.3.2.0 utilizando o pacote heatmap.2. Análise com distância euclidiana e usando o algorítimo UPGMA. O agrupamento do genes foi baseada na semelhança do padrão de expressão.

\section{Genes de resistência $(\mathbf{R})$.}

Sete genes relacionados com resistência contra diversos patógenos foram diferencialmente modulados em planas induzidas com Serratia sp. (Figura 13; Anexo tabela 8). Quatro deles foram reprimidos, entre eles o gene Pi2/9 que possui o sítio NBS-LRR e confere resistência à algumas raças de $M$. oryzae. Três genes foram superexpressos, entre eles $O s X B 3$, relacionado a resistência de arroz a Xanthomonas oryzae pv. oryzae. 


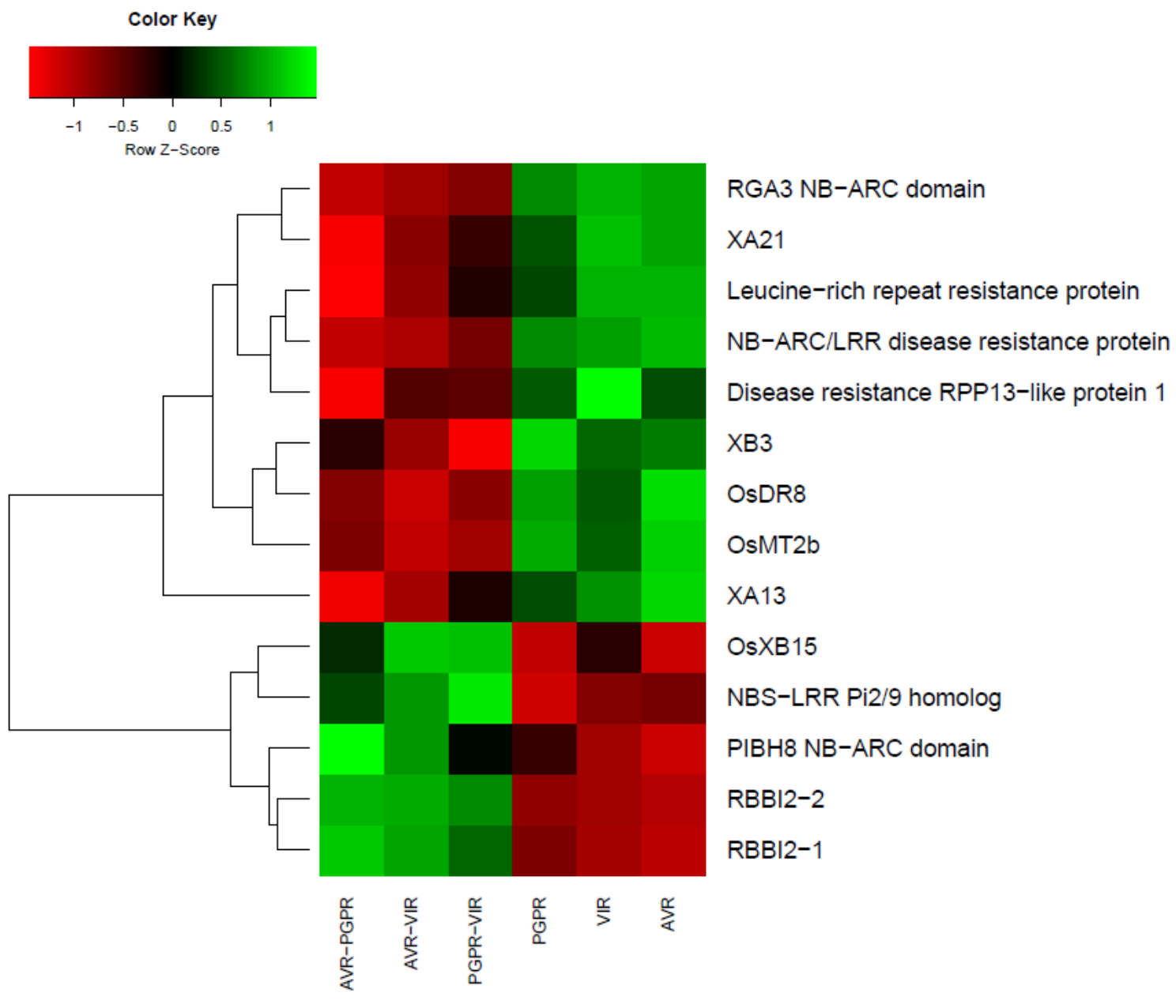

Figura 13. Clusterização e heat map da expressão de genes relacionados com resistência (R) modulados segundo os diferentes tratamentos. A escala de cor indica o valor de expressão. O heat map foi gerado no programa R v.3.2.0 utilizando o pacote heatmap.2. Análise com distância euclidiana e usando o algorítimo UPGMA. O agrupamento do genes foi baseada na semelhança do padrão de expressão.

Dois genes responsivos a mais de um hormônio de defesa foram encontrados sendo diferencialmente expressos neste trabalho: OsNPR4 e OsStr11 (Os02g49680). OsNPR4, responsivo a JA e SA, foi reprimido. Quando os valores de expressão (FC) de PGPR foram normalizados com VIR, houve diferença significativa nos níveis de expressão (Figura 14; anexo tabela 11). 

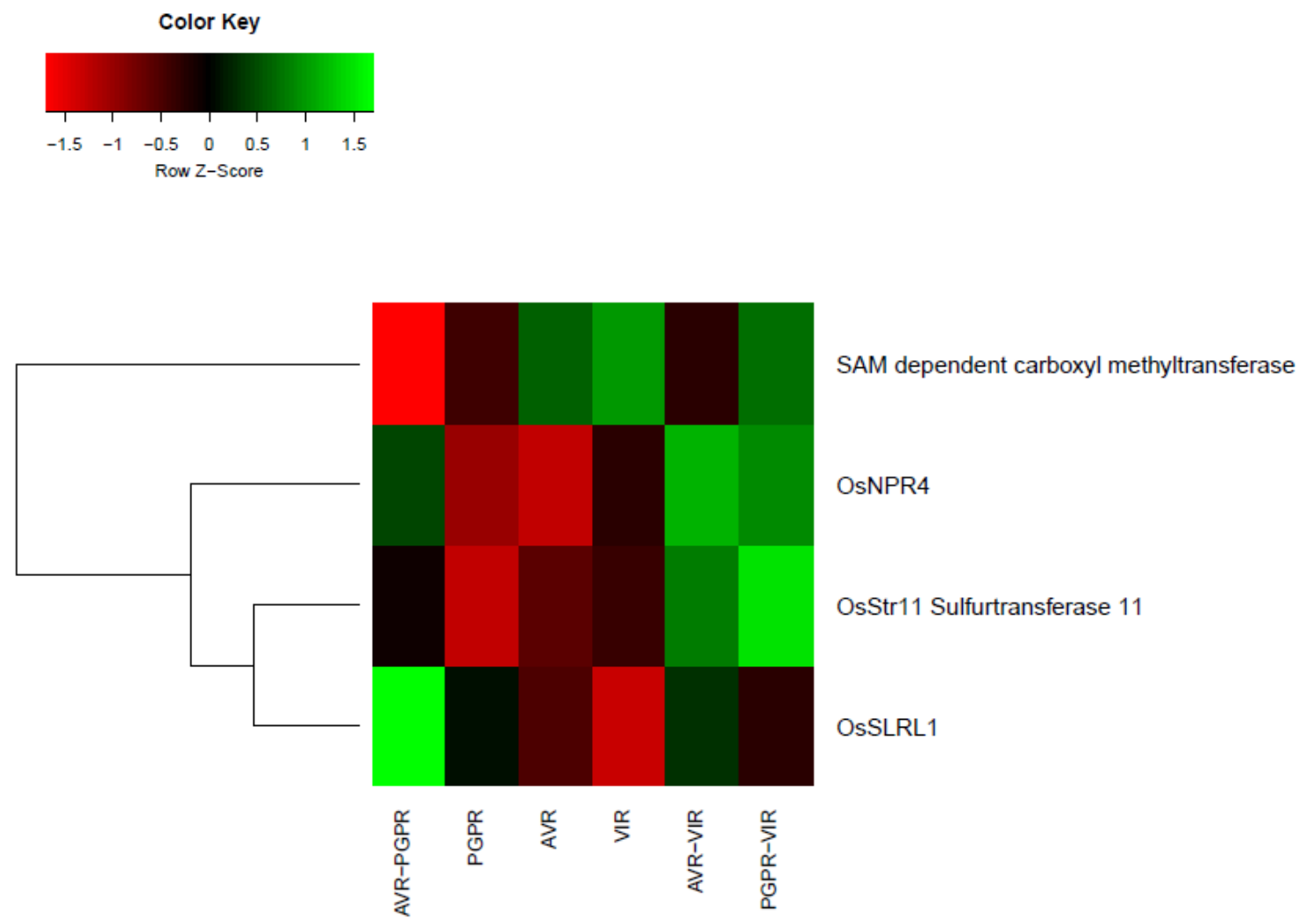

Figura 14. Clusterização e heat map da expressão de genes envolvidos na interação de hormônios de defesa e modulados segundo os diferentes tratamentos. A escala de cor indica o valor de expressão. O heat map foi gerado no programa R v.3.2.0 utilizando o pacote heatmap.2. Análise com distância euclidiana e usando o algorítimo UPGMA. O agrupamento do genes foi baseada na semelhança do padrão de expressão.

\subsection{DEGs em plantas induzidas com M. oryzae avirulento PY10749.}

Para investigar os genes envolvidos com SA, foi avaliada a expressão de genes relacionados com a biossíntese de SA e genes a eles responsivos, bem como a via biossintética de duas vias precursoras ao SA: rota do chiquimato e do triptofano (Figura 5; Anexto tabela 2). No presente trabalho, seis genes relacionados com via do chiquimato foram superexpressos em AVR, sendo o gene Os10g42700 (uma quinasechiquimato que transforma 3-dehidro-chiquimato em chiquimato) exclusivo desta condição. Três genes relacionados a biossíntese do triptofano foram DEGs: um reprimido e dois superexpressos. Apenas um gene envolvidos com a síntese de salicilatos foi diferencialmente expresso em AVR: OsPALO2 foi superexpresso nesta condição (Figura 5; Anexo tabela 2).

Onze genes que fazem parte da biossíntese do JA foram diferencialmente expressos, a maioria reprimido (7 genes) e apenas 4 superexpressos (Figura 6; Anexo tabela 3). Dos sete genes com atividade de Lipoxigenase que foram DEGs, apenas OSLOX8 foi superexpresso. OSOPR1 (atua no precursor do isojasmonato), proteína 
ribossomal L7/L12 (Os01g47330), OsAOS1 (oxidase do alene) (Os03g55800) e fosfolipases A2 (Os01g40070 e Os03g50030), genes estes que atuam nas moléculas precursoras do metil-éster ácido jasmônico, também foram DEG nas plantas que receberam $M$. oryzae avirulento. Genes envolvidos na regulação da síntese de JA, como JAZ (Jasmonate Zim Domain) também foram diferencialmente modulados: todos os cinco foram reprimidos. Genes responsivos a JA também foram diferencialmente modulados. $O s M Y C 2$, um gene de um fator de transcrição relacionado com ativação de genes responsivos ao JA, foi reprimido. OsRERJ1, genes envolvido na acumulação de JA, foi superexpresso (Figura 6; Anexo tabela 3).

Três genes de arroz relacionados com a síntese de ET foram encontrados (Anexo tabela 4). Um gene ACC sintase (OsACS5 - Os01g09700) foi reprimido. Dois genes ACC oxidase, envolvidos na segunda etapa da biossintese desse hormônio, OsACO3 e OsACO7, foi reprimido e superexpresso, respectivamente. A transdução de sinal do etileno entre os receptores e o núcleo é governado por produtos dos genes EBF (EIN3BINDING F-BOX); estes foram reprimidos apenas neste tratamento apenas AVR (OsEBF1 e OsEBF2).Genes ERF regulam a transcrição des genes envolvidos em resposta ao etileno, deles foram DEGs em AVR (Figura 7; anexo tabela 4).

Genes de proteínas relacionadas a patogênese de diferentes famílias foram encontrados (Anexo tabela 5). O gene OsPRla, cujo produto possui atividade de proteinase, foi reprimido em AVR. Um gene da família PR5 (OsPR5 - Os03g45960) foi encontrado com valores positivos de FC (Figura 8; anexo tabela 5). O produto do gene OsScil, que pertence à famíla PR6, possui atividade inibidora de proteinase, também foi superexpresso em AVR. Enzimas com atividade de $\beta$-1,3-glucanase pertencem a família PR2. Onze DEGs dessa família foram encontrados neste tratamento. Nove foram superexpressos e apenas 2 foram reprimidos, fazendo deste tratamento (AVR) aquele que mais ativou essas enzimas, inclusive apresentando DEGs exclusivos (Figura 8; anexo tabela 5). A presença de $M$. oryzae avirulento aumentou a expressão de genes que codificam enzimas com atividade de quitinase (CHI). Estas enzimas pertencem a famílias de proteínas PR PR3, 4, 8 e 11. Dez membros dessas famílias foram DEGs em AVR, sendo este tratamento aquele com mais genes CHI que foram DEG, onde todos eles foram superexpressos. Alguns desses DEGs foram exclusivos a esta condição (Figura 8; anexo tabela 5). Trinta e um genes que codificam enzimas com atividade de peroxidase foram DEG. Nove deles foram reprimidos; os outros 22 foram superexpressos. Os03g55420 foi o único DEG presente nas plantas tratadas com $M$. 
oryzae, sendo up-regulated na condição AVR. Assim como em PGPR, dois DEGs da maquinaria celular de detoxificação de EROs como ascorbato-peroxidase (OsAPX3) e catalase (OsCATB) foram encontrados (Figura 8; anexo tabela 5).

Onze genes da superfamília de genes $W R K Y$, que são fatores de transcrição envolvidos em respostas de defesa, foram diferencialmente expressos neste tratamento. Nove deles foram modulados negativamente, com exceção dos genes OsWRKY17 e OsWRKY31. Deste total, dois foram DEG somente em AVR (OsWRKY42 e OsWRKY96) (Figura 9; anexo tabela 6).

De forma semelhante aos fatores de transcrição mencionados anteriormente, 11 genes pertencentes à família de proteínas quinases ativadas por mitógenos foram encontrados em plantas induzidas com $M$. oryzae avirulento, onde oito deles foram reprimidos (MAPK 1 e 5; MAPKK 4 e 10-2; MAPKKK 3, 20, 62 e 70) e apenas três superexpressos (MAPK 10; MAPKKK 30 e 74) (Figura 10; anexo tabela 7).

Dos genes relacionados com fitoalexinas que foram diferencialmente expressos, apenas três foram encontrados em AVR: um gene relacionado com momilactonas (OsKO4), uma fitoalexina sintetizada a partir dos fenilpropanoides, e dois genes relacionados com maaquiaina (Os01g01650 e Os01g660), uma fitoalexina do grupo dos isoflavonoides (Figura 11; anexo tabela 9).

Em plantas de arroz tratadas com M. oryzae AVR, encontramos 21 genes que pertencem a essa classe de monooxigenases (Figura 12; anexo tabela 10). O número de DEGs que foram superexpressos foi maior do que aqueles reprimidos, 13 e 8 , respectivamente.

Nove genes relacionados com resistência contra diversos patógenos foram diferencialmente modulados nas condições estudadas (Anexo tabela 8). Três deles foram comum a todas as condições. $O S R F 2 B$ (Os01g03310), que confere resistência ao vírus RTBV foi reprimido e DEG nos três tratamentos. Dois genes R contra infecção causada por Xanthomonas oryzae pv. oryzae foram DEGs: OsXA13 (Os08g42350) e OsXA21 (Os11g35500) ambos superexpressos. O gene PIBH8 (Os08g42700), que confere resistência à $M$. oryzae, foi reprimido. Genes que codificam as proteínas $R P P 13$ protein 1 e RPP13-like protein 1 (Os10g04090 e Os03g14900, respectivamente) e que contém o domínio NB-LRR foram superexpressos em AVR. Outros genes relacionados com resistência à patógenos foram encontrados (Figura 13; anexo tabela 8).

Genes responsivos a mais de um hormônio de defesa foram encontrados sendo diferencialmente expressos neste trabalho. Neste tratamento (AVR), o gene OsNPR4 foi 
e reprimido em AVR. Houve diferença significativa nos níveis de expressão quando os valores de expressão (FC) desses tratamentos foram normalizados com VIR (Figura 14; anexo tabela 11).

\subsection{DEGs em plantas induzidas com $M$. oryzae virulento PY10900.}

Cinco genes relacionados com via do chiquimato foram diferencialmente expressos nas condições avaliadas, todos up-regulated, são eles: OsDHQDT/OsSDH, OsDAHP1, OsDAHPS1, OsEPSPS5 e OsSK3. Apenas dois genes relacionados com a síntese do triptofano foram DEGs em VIR: Anitrilato fosforibosiltransferase e Indol-3glicerol fosfato-liase. Estes foram superexpresso e reprimido, respectivamente. OsPALO2 e OsPAL03, ambos com atividade de fenilalanina amônio-liase e relacionados com biossíntese de salicilatos, foram superexpressos em plantas tratadas com M. oryzae virulento (Figura 5; Anexo tabela 2).

Apenas oitos genes envolvidos na biossíntese do JA foram diferencialmente expressos em VIR. Entretanto, diferente de plantas tratadas com Serratia sp. e $M$. oryzae AVR onde houve mais DEGs reprimidos do que superexpressos, cinco genes foram positivamente regulando e apenas três apresentaram valores de FC negativos (Figura 6; Anexo tabela 3). Apenas um DEG foi exclusivo desse tratamento: OsLOX1. Dois genes das proteínas JAZ (Jasmonate Zim Domain) (proteínas reguladoras da ativação da biossíntese de JA) bem como outros genes responsivos ao JA também foram modulados (Figura 6; Anexo tabela 3).

Três genes envolvidos na síntese de ET foram modulados diferencialmente em plantas de arroz neste tratamento (Anexo tabela 4). OsACS5 (ACC sintase) foi reprimido. OsACO3 e OsACO5, ambos envolvidos na segunda etapa da biossíntese de etileno, foram reprimidos e superexpressos, respectivamente. Apenas dois genes ERFs (regulam a transcrição de genes envolvidos em resposta ao ET) foram DEG: OsERF93 (reprimido) e OsERF101 (superexpresso) (Figura 7; anexo tabela 4).

Várias proteínas PR tiveram seus respectivos genes diferencialmente expressos. OsPRIb, cujos produtos são inibidores de proteinases, foi DEG exclusivo de VIR, com valor de FC positivo, com valores também significativo quando normalizado com os valores de FC dos demais tratamentos. Dois genes da família proteica PR10, com atividade de ribonuclease foram encontrados: OsPR10 e OsPR10B PBZ1, ambos superexpressos. Assim como em PGPR e AVR, OsPR5 foi superexpresso (Figura 8; 
anexo tabela 5). A famíla PR6 é aqui representada pelo gene OsScil (Os12g25090), também superexpresso em VIR.

Apenas sete genes relativos a $\beta$-1,3-glucanase foram DEGs. OsEGL2 foi reprimido e DEG exclusivo de AVR. Seis genes com atividade de GLU foram superexpressos. Oito genes com atividade de quitinase (CHI) foram superexpressos em plantas tratadas com $M$. oryzae virulento, quantidade inferior ao observado em AVR mas superior a PGPR.

Dos genes que codificam enzimas com atividade de peroxidase (POX), apenas 20 foram DEG em VIR; menor número dentre os tratamentos deste trabalho. Deste total, somente 1 foi reprimido, a maioria foi superexpresso (19). NADPH oxidase de plantas, aqui representadas pelos genes OsRbohC (Os05g45210) e OsRbohH (Os12g35610) foram DEGs e superexpressos apenas nas plantas desafiadas com $M$. oryzae virulento. Entre as funções atribuídas a estes genes, estão a produção de espécies reativas de oxigênio (EROs) e morte celular programada. DEGs da maquinaria celular de detoxificação de EROs como oxidase-alternativa $(O s A O X 1 a)$ e ascorbato-peroxidase (OsAPX3 e OsAPX7) também foram DEG; diferente das POXs, esses genes foram mais numerosos neste tratamento.

A superfamília de WRKY, fatores de transcrição, possui mais de 100 genes em arroz. Deste total, apenas 5 foram diferencialmente modulados em VIR (Figura 9; anexo tabela 6). Dois apresentaram valores positivos de FC e três genes foram reprimidos. Dentre estes reprimidos, OsWRKY58 foi exclusivo de plantas tratadas com M. oryzae virulento.13 foram DEG nas condições avaliadas (Figura 9), também apresentando FC significativo quando seus valores de expressão foram normalizados com PGPR.

Plantas tratadas com $M$. oryzae AVR apresentaram sete genes de proteínas quinases ativadas por mitógenos, sendo este o menor número dentre as condições avaliadas. Desse total, quatro foram reprimidos (MAPK1, MAPKK10-2, MAPKKK3 e $M A P K K K 70)$ e três apresentaram valores de FC positivos (MAPK10, MAPKKK30 e MAPKKK74) (Figura 10; anexo tabela 7).

Nas condições em que plantas de arroz foram aqui estudadas, 10 genes relacionados com fitoalexinas foram diferencialmente expressos com valores positivos de FC (Anexo tabela 9). A presença do isolado M. oryzae virulento PY10900 modulou positivamente esses genes. Todos genes foram DEG e superexpressos em VIR. Desse total, oito DEGs são relacionados com fitocassano e momilactonas, duas das fitoalexinas sintetizadas a partir da via metabólica dos fenilpropanoides e dois genes 
relacionados com maaquiaina (Os01g01650 e Os01g660), uma fitoalexina do grupo dos isoflavonoides.

Vinte e dois genes do citocromo P450, um grupo de enzimas envolvidas na catálise da oxidação de diversos substratos por meio da ativação do oxigênio molecular, foram DEG em VIR. Elas estão envolvidas no processo metabólico de várias vias de sinalização relacionadas com respostas de defesa da planta, como hormônios vegetais, fitoalexinas e lignina. A maioria dos genes (16) foram superexpressos e apenas seis foram reprimidos (Figura 12; anexo tabela 10).

Genes relacionados com resistência contra diversos patógenos foram diferencialmente modulados em VIR (Figura 13; anexo tabela 8). Dois genes R contra infecção causada por Xanthomonas oryzae pv. oryzae foram superexpressos (OsXA13 e OsXA21) em AVR e VIR, todos eles superexpressos. O gene PIBH8 (Os08g42700) bem como o gene homólogo ao Pi2/9 (ambos conferem resistência à $M$. oryzae) foram reprimidos.

Genes responsivos a mais de um hormônio de defesa foram encontrados sendo diferencialmente expressos neste trabalho. O gene SAM (ácido salicílico carboxil metiltransferase, Os06g20960) foi superexpresso. Já o gene OsSLR1 foi DE e reprimido apenas em VIR (Figura 14; anexo tabela 11).

\subsection{Validação dos dados de RNAseq via qRT-PCR}

Para validação dos dados do sequenciamento do transcriptoma via RNA-seq, dez DEGs foram selecionados baseados no seu padrão de expressão (FC) para fazer quantificação de expressão também via RT-PCR quantitativo (qRT-PCR) usando as mesmas amostras utilizadas para RNA-seq. O resultado da expressão fornecida pelo técnica de RNA-seq e aqueles mostrados pela qRT-PCR mostraram concordância entre si (Figura 15), demonstrando similaridade no nivel de expressão analisados pelas duas técnicas, fornecendo solidez ao dados de indução aqui apresentados. 

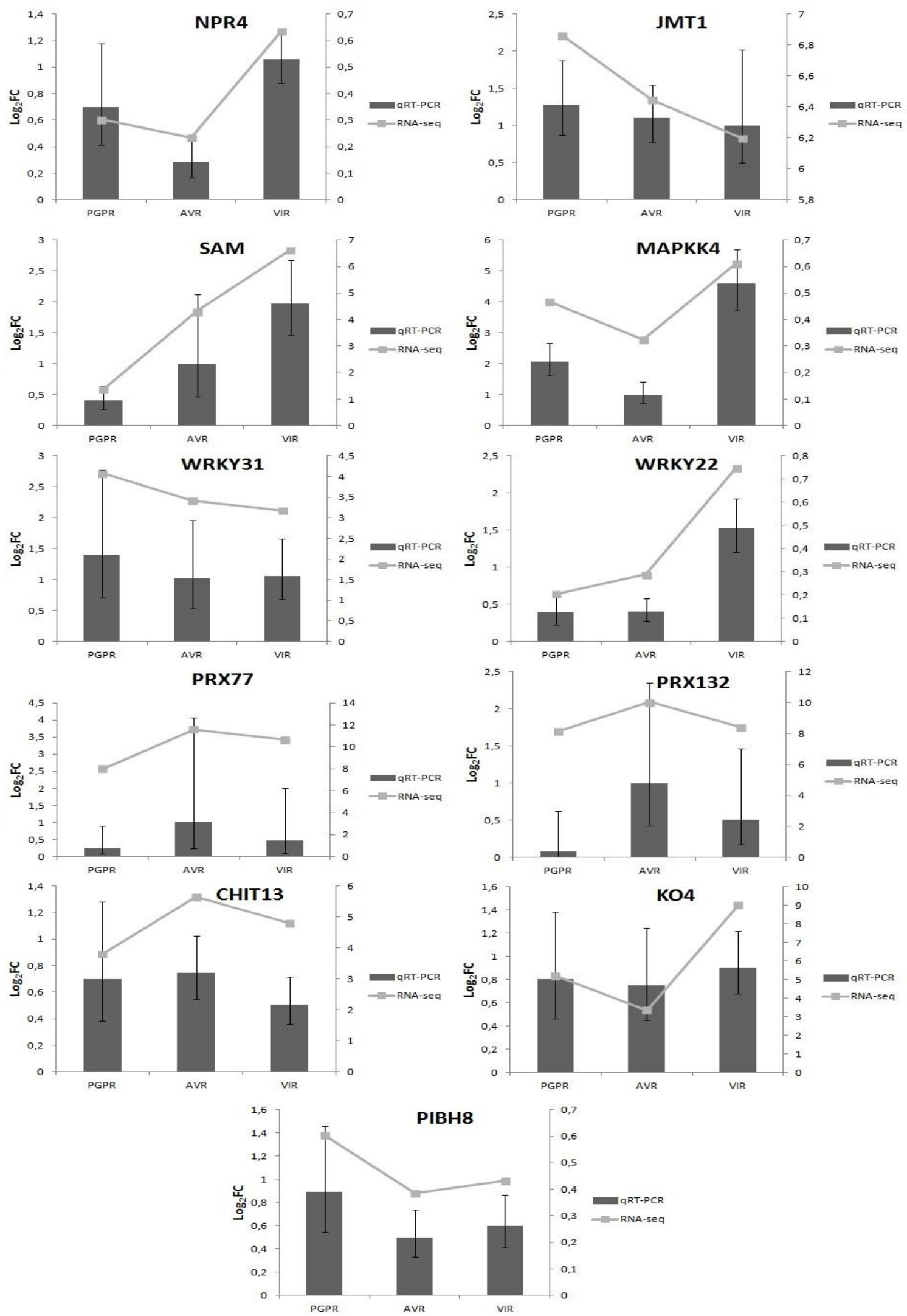

Figura 15 - Validação via qRT-PCR dos dados da expressão relativa do genes obtidos via RNA-seq. Níveis de expressão dos transcritos selecionados estão na barra preta (qRT-PCR) e na linha (RNA-seq). Dois genes, um de actina e outro de ubiquitina foram utilizados para normalização dos dados de qRTPCR. As barras de erro indicam o desvio padrão para ensaios feitos com duplicata técnica. 


\section{DISCUSSÃO}

É notável que o perfil dos transcritoma dos três tratamentos foram diferentes (Figura 1). Levando-se em consideração a quantidade de genes modulados de forma diferencial, M. oryzae avirulento (AVR) foi o que apresentou o maior número de DEGs, seguido pelo indutor PGPR que pertence ao gênero Serratia sp. BRM32114 (PGPR) e M. oryzae virulento (VIR) (Figura 3).

A base genética dos componentes envolvidos na transdução de sinal que medeiam a relação entre PGPR e plantas é pouco conhecida com poucas informações relacionadas com a mudança no transcritoma de plantas colonizadas por rizobactérias (Stearns et al., 2012; Poupin et al., 2013). Até onde sabemos, esse é o primeiro relato de estudo relacionado com a mudança global na transcrição de genes em arroz induzido por Serratia sp. Os dois isolados de $M$. oryzae foram diferentes em relação ao trascritoma. Levando-se em consideração genes relacionados as resposta de defesa, a mudança no nível de expressão desencadeados na relação Oryzae sativa-M. oryzae é maior na interação incompatível do que na compatível. Isso sugere que as reações responsivas envolvidas na defesa da planta ao ataque do patógeno são mais ativas na interação incompatível (Kawahara et al., 2012).

$\mathrm{O}$ perfil dos genes diferencialmente expressos nas plantas tratadas com os isolados de $M$. oryzae foram semelhantes. A quantidade de genes superexpressos em relação aos genes reprimidos foi maior nos tratamentos com o fungo $M$. oryzae (tanto AVR quanto VIR) do que nas plantas tratadas com PGPR (Figura 2). A quantidade de DEGs em comum entre AVR e VIR pode ser atribuído à natureza dos microrganismos, que apesar da diferença entre a virulência, se trata da mesma espécie de fungo, nada obstante a diferença entre o número de DEG observado em cada uma dessas condições (Figura 4). Apesar de se tratarem de agentes indutores diferentes, AVR e PGPR tiveram uma alta quantidade de DEGs compartilhados. Isso sugere que embora sejam agentes indutores distintos, há semelhanças nos mecanismo por eles são ativados nas plantas, contudo, existem particularidades no perfil gênico ativado em cada um desses tratamentos, como demonstrado pelos DEGs exclusivos em cada um. A alteração na resposta diferencial dos transcritos relacionados a defesa do arroz pode ser atribuída à diferença dos agentes indutores, indicando que fungos fitopatogênicos virulentos e rizobactérias desencadeiam diferentes respostas na planta de arroz. Além daqueles genes envolvidos em vias de sinalização de defesa, PGPRs podem promover o 
crescimento e alteram rotas metabólicas envolvidas em outros processos fisiológicos da planta (Stearns et al., 2012).

SA desempenha papel importante na resistência e defesa contra ataque de fitopatógenos. Em plantas induzidas com Serratia sp. BRM32114, genes envolvidos na síntese de SA e dos seus precursores, chiquimato e triptofano, foram modulados de forma diferencial. Três genes relacionados ao chiquimato foram superexpressos, bem como dois genes relacionados ao triptofano. Três genes com atividade de PAL também foram superexpressos nesta condição. Isso sugere que há uma modulação desses genes envolvidos com SA em plantas de arroz após a inoculação com Serratia sp. Trabalhos com Azospirillum também em arroz demonstraram a expressão diferencial de genes envolvidos na síntese de SA (Drogue et al., 2014). Estes resultados corroboram com aqueles apresentados neste trabalho no capítulo 1, onde plantas induzidas com Serratia sp., quando comparadas com os demais tratamentos, apresentaram maiores concentrações de SA antes e após o desafio com $M$. oryzae. Usa-se o termo SAR para indução de resistência ativada por patógenos ou dependente de SA e para ISR quando a indução de resistência é ativada por microrganismos benéficos (por exemplo: PGPR ou PGPF) de forma independente de SA e dependente de JA/ET (Pieterse et al., 2014). Entretanto, diferente das informações contidas na maioria dos trabalhos, os resultados aqui apresentados indicam que indução de resistência em arroz ativada por rizobactérias aconteça de forma dependente de SA e que este hormônio interfere nas respostas de indução governadas por de JA e ET. Isso sugere que, em algumas situações, o termo SAR possa ser utilizado para induções dependentes de SA ativadas por PGPR ou que ISR englobe esse tipo de situação.

Jasmonato é um fitormônio que desempenha papel fundamental no crescimento de plantas e em respostas de defesa (Liu et al., 2015). No total, 8 genes envolvidos na biossíntese de JA foram DEG em PGPR, porém, a maioria desses genes foram reprimidos. Genes que codificam enzimas com atividade de LOX tiveram valores negativos de FC; o mesmo se deu com genes responsivos a JA. Esses resultados estão de acordo com aqueles encontrados no capítulo 1 onde avaliou-se a atividade dessa enzima. Nos primeiros momentos avaliados, a atividade de LOX foi menor nas plantas tratadas com rizobactérias do que nas testemunhas (plantas apenas desafiadas com $M$. oyzae). Esses resultados diferem de alguns trabalhos nos quais verificou-se a superexpressão de genes envolvidos na biossíntese de JA bem como aqueles 
responsivos a este hormônio em plantas tratadas com rizobactérias (Pieterse et al., 2014; Kouzai et al., 2016).

Todos os três genes envolvidos na síntese etileno encontrados em PGPR foram reprimidos. O gene ACC sintase apresentou um FC negativo (OsACS5), (Figura 7; anexo tabela 4). Essa enzima catalisa o primeiro passo da via do etileno clivando o ácido 1-carboxílico-1-aminociclopropano (ACC), precursor imediato do etileno (Rzewuski, et al., 2008). Os outros dois genes reprimidos foram OsACO3 e OsACO7. ACC oxidase catalisa a segunda etapa da biossíntese deste hormônio. Quando estirpes de Azospirillum foram inoculadas em arroz, genes da síntese de ET foram reprimidos (Drogue at al., 2012). Quatro genes ERF com modulação diferencial foram encontrados em AVR e PGPR. Genes OsERF regulam a transcrição de genes envolvidos em resposta ao etileno (Riechman \& Meyerowitz, 1998). PGPRs podem interferir na síntese de etileno nas plantas, diminuindo o nível desse hormônio por ter a capacidade de também produzi-lo (Stearns et al., 2012).

Sete genes da família PR-2 foram DEG em plantas induzidas com Serratia sp. BRM32114. Essas enzimas apresentam atividade de $\beta$-1,3-glucanase, clivando $\beta-1,3-$ glucano. A presença da rizobactéria ocasionou a superexpressão de cinco genes e repressão de dois genes desses genes (Figura 8; anexo tabela 5). Diversos trabalhos nos quais foram utilizados rizobactérias como agentes indutores demonstraram um aumento na atividade de GLU nas plantas tratadas (Filippi et al., 2011; Raj et al., 2012). Assim como GLU, genes que codificam CHI também foram superexpressos, embora a quantidade desses genes tenha sido menor do que nas plantas tratadas com os isolados de $M$. oryzae AVR e VIR. Apenas cinco genes CHI foram superexpressos. Essa diferença pode ser atribuída à presença de quitina na parede celular dos fungos e ausente em bactérias (Minic, 2008). O gene Sci, similar ao MPI encontrado em milho, foi DEG em todas as condições, sendo mais superexpressos em PGPR. O produto desse gene é uma enzima que possui atividade inibidora de proteinase, sendo induzida em respostas a ferimentos causados por herbivoria e em resposta ao ataque de patógenos (Vila et al., 2005). Diferente das outras PRPs aqui citadas, plantas induzidas com Serratia sp. apresentaram o maior número de genes $P O X$ (ou $P R X$ ) modulados diferencialmente dentre as três condições citadas com 33 representantes: 22 superexpressos e 13 reprimidos., . Embora PGPR também sejam capazes de ativar enzimas relacionadas a estresse oxidativo (García-Cristobal et al., 2015), este foi dentre os tratamentos que teve maior números de genes $P O X$ reprimidos e maior quantidade de reprimidos. Apenas 
dois genes envolvidos com metabolismo antioxidante foram DEG (OsAPX8 $e$ OsCATB). Talvez isso tenha relação com a grande quantidade de genes POX reprimidos. O genes $O s P R 10 B$, membro da família PR-10, foi superexpresso em plantas induzidas com Serratia sp. O produto desses genes possui atividade de ribonuclease e pode desencadear respostas de defesa como a morte celular programada em plantas (Kim et al., 2011). Este é o primeiro relato de rizobactérias induzindo resistência e modulando diferencialmente gene dessa família em arroz.

Dez fatores de transcrição pertencentes à familia $W R K Y$ foram DEGs. A maioria deles foi reprimida (8 genes); apenas $O s W R K Y 17$ e $O s W R K Y 31$ foram superexpressos (Figura 9; anexo tabela 6). A superexpressão do gene OsWRKY31 pode conferir resistência a brusone do arroz (Zhang et al., 2008). Dentre esses TF, há genes responsivos a hormônios de defesa e ao ataque de patógenos, como o gene OsWRKY22 apresentou os menores valores de FC em PGPR. Ele está envolvido na resistência de arroz a M. oryzae e a outros fungos não-patogênicos ao arroz (Abbruscato et al., 2012). Alguns desses genes permaneceram como DEGs quando seus valores de FC foram normalizados com VIR, candidatando-os como marcadores de indução.

A cascata de MAPK é composta de três proteínas quinases ligadas funcionalmente, onde MAPK é fosforilada e ativada por uma MAPK quinase (MAPKK) que por sua vez é ativada por outra proteína quinase: MAPKK quinase (MAPKKK). OsMAPKK4 que foi DEG em PGPR, está envolvido nos estágios iniciais da infecção, morte celular e na via dos diterpenóides, tanto em reações compatíveis quanto em incompatíveis (Kawahara et al., 2012). Proteínas quinases são conhecidas também por atuarem no reconhecimento de PAMPs e MAMPs (Kishi-Kaboshi et al., 2010; Yang et al., 2015).

Pi2/9 (Os06g17970), gene $\mathrm{R}$ a brusone, foi DE apenas em PGPR. Esse envolvimento de PGPR na ativação de genes R em arroz já foi relatado (Drogue et al., 2014). $X B 3$, qene $\mathrm{R}$ relacionados a queima bacteriana, foi superexpresso apenas nas plantas induzidas com a rizobactéria. Isso pode ser atribuído à natureza do agente indutor ser semelhante ao do patógeno.

Genes que codificam fitoalexinas do arroz foram superexpressos em PGPR: dois do grupo dos flavonoides e cinco dos diterpenoides. Um gene que codifica uma isoflavona (Os01g01660) apresentou diferenças significativas em relação às outras condições (Figura 11; tabela anexo 9). Drogue et al. (2014) observaram a produção de fitoalexinas em arroz após o contato com rizobactérias. 
Os resultados indicam que plantas tratadas com PGPR apresentaram maiores números de DEGs relacionados com P450. Desse total, 28 foram DE em PGPR, $22 \mathrm{em}$ AVR e 22 em VIR. Há na literatura diversos trabalhos relacionados com a expressão diferencial de genes P450 induzida por patógenos (Abbruscato et al., 2012; Matic et al., 2016), entretanto, como aqui observado, rizobactérias promotoras de crescimento de plantas também possuem essa capacidade (Kurabachew et al., 2013; Drogue et al., 2014), sugerindo que estas também são capazes de modificar genes envolvidos nessa rota metabólica.

Algumas proteínas reguladoras envolvendo o cross-talk entre SA e JA em arroz já foram identificadas, dentre elas estão as proteínas NPRs (De Vleesschauwer et al., 2013) que, além desse papel regulador de vias hormonais, também está envolvido em respostas de defesa e indução de resistência (Pajerowska-Mukhtar et al., 2013). O gene OsNPR4 foi reprimido em PGPR, apresentando diferença significativa quando o FC desse tratamentos foi normalizado com VIR.

A presença de $M$. oryzae avirulento modulou de forma diferencial alguns genes relacionados com a biossíntese de SA e seus precursores. Na via do chiquimato, seis genes foram superexpressos. Três genes envolvidos na síntese do triptofano foram encontrados com expressão diferenciada, $\mathrm{O}$ gene que codifica a enzima anitrilato sintase (OsASA1) (Figura 5; anexo tabela 2) foi DEG apenas nas plantas induzidas com $M$. oryzae avirulento. Essa enzima está associada à sintese de compostos de defesa derivados da via do triptofano (Maeda \& Dudaeva, 2012). Durante respostas de defesa, muitas plantas usam componentes derivados dos fenilpropanóides para se defender e as enzimas PAL são componentes-chaves nessa via metabólica, participando diretamente da biossíntese de SA (Kouzai et al., 2016). OsPAL02 apresentou maiores valores de FC em AVR. O aumento da expressão de genes envolvidos nas diferentes etapas de síntese de SA é comum em plantas apresentando SAR (Bagnaresi et al., 2012).

Assim como em PGPR, plantas induzidas com AVR apresentaram um maior número de genes reprimidos da biossíntese de JA do que genes superexpressos. No total foram encontrados 11 DEGs, sete reprimidos e 4 superexpressos (Figura 6; anexo tabela 3). Este é um fitormônio que desempenha papel fundamental em respostas de defesa (Liu et al., 2015) entretanto, em arroz, JA não é eficaz em respostas de defesa nos primeiros momentos da infecção por $M$. oryzae, sendo efetivo apenas na fase necrotrófica da colonização. Outros genes responsivos a JA e envolvidos também em respostas de defesa foram DEG nas condições avaliadas. OsJAC1 e OsHPL3 podem 
conferir resistência a herbivoria. Estes e outros genes regulam respostas de defesa contra patógenos, como morte celular e, dependendo do nível de expressão, podem conferir resistência ou desencadear suscetibilidade a estresses bióticos (Tong et al., 2012; Ishiga et al., 2013).

A maioria dos DEGs envolvidos na síntese de ET e, principalmente, aqueles responsivos a este hormônio, foram encontrados em AVR. A presença do isolado de $M$. oryzae avirulento reprimiu grande parte desses genes. Genes que codificam componentes de sinalização do etileno como $E B F$ foram DEG apenas em AVR (OsEBF1 e OsEBF2), ambos reprimidos. $E B F$ são genes envolvidos na transdução de sinal do etileno entre o receptor e o núcleo, ativando cascata de sinais de componentes após a detecção do etileno. Eles agem como proteínas $F$-box, envolvidos na interação proteína-proteína (Rzewuski, et al., 2008). Uma das características de SAR é o acúmulo de SA. Assim como JA, ET também pode ser antagônico ao SA em respostas de defesa de plantas (Pieterse et al., 2014). A repressão dos genes envolvidos com ET aqui encontrada pode devido a planta estar no "modo" SAR, onde suas respostas são mais efetivas contra a fase biotrófica de M. oryzae.

O gene OsPRla foi reprimido e DEG apenas nas plantas induzidas com $M$. oryzae avirulento (Figura 8; anexo tabela 5). PR-1 possui atividade antifúngica e é a PRP mais abundante dentre as 17 famílias acumulando de 1 à $2 \%$ do conteúdo proteico total da planta. A expressão de genes PR1 pode ser utilizada com marcador molecular para indicar respostas de defesa da planta (Gordon et al., 1997). A presença do isolado avirulento aumentou a expressão de genes cujo produto são enzimas com atividade de $\beta$-1,3-glucanase. Estas são enzimas da família PR-2. A expressão diferencial de genes PR-2 pode indicar a ativação de mecanismos de degradação da parece celular de fungos uma vez que esses fitopatógenos possuem $\beta$-1,3-glucana como constituinte dessa estrutura. Bagnaresi et al. (2012) encontraram um maior número de genes que codificam $\beta$-1,3-glucanase em interações incompatíveis no patossitema Oryza sativaMagnaporthe oryzae. Esses resultados estão de acordo com os resultados encontrados no segundo capítulo deste trabalho onde plantas de arroz induzidas com $M$. oyzae avirulento tiveram uma maior atividade de GLU quando comparada com as plantas não induzidas. Quitinases (CHI), outras enzimas envolvidas na degradação de produtos contidos na parede celular de fungos foi DEG nas condições aqui avaliadas. Dez genes que codificam quitinases (CHI) foram encontrados em AVR sendo superexpressos (Figura 8; anexo tabela 5). A presença do fungo avirulento foi mais eficiente na ativação 
diferencial desses genes. Assim como observado no presente trabalho, outros artigos relatam a um aumento na quantidade de genes diferencialmente expressos que codificam CHI em plantas, especialmente em interações incompatíveis entre patógeno e hospedeira (Bagnaresi et al. 2012; Matic et al., 2016). Quitinases têm representantes em quatro famílias de PRPs: PR-3, PR-4, PR-8 e PR-11. Essas enzimas hidrolisam a ligação $\beta, 1-4$ de cadeias de quitina encontradas na parede de patógenos, produzindo Nacetilglucosamina, constituindo o segundo maior grupo de proteínas antifúngicas (Ferreira et al., 2007). A expressão diferencial de quitinases e glucanases encontradas neste trabalho indicam suas funções mútuas de degradação da parede celular fúngica (Minic, 2008). Sob estresse, a produção de espécies reativas de oxigênio é induzida. O tratamento AVR foi o que apresentou maior número de genes $P O X$ superexressos, 22 genes de um total de 31. (Figura 8; anexo tabela 5). Isolados avirulentos de M. oryzae são capazes de ativar enzimas relacionadas a estresse oxidativo (Kim et al., 2009). Essa incompatibilidade entre patógeno-hospedeiro tem como uma das respostas o acúmulo de POX. Esses resultados respaldam aqueles encontrados no capítulo 2 onde plantas induzidas com isolado PY10749 AVR apresentaram uma maior atividade de POX, antes e após o desafio com M. oryzae virulento.

A maioria dos genes WKRY diferencialmente modulados em AVR foram reprimidos. Alguns estudos em arroz indicam a complexidade do papel dos fatores de transcrição WRKY desempenham em respostas de defesa, onde a superexpressão de genes WRKY como WRKY96 leva à um aumento na resistência contra Xanthomonas oryzae pv. oryzae e a repressão de WRKY4 pode ocasionar suscetibilidade. Resultados semelhantes foram encontrados por Bagnaresi et al. (2012) onde vários genes WRKY foram modulados negativamente em cultivares de arroz resistentes à $M$. oryzae.

Neste estudo, 11 genes que codificam proteínas quinases foram diferencialmente expressos em AVR: 8 reprimidos e 3 superexpressos. Este foi o tratamento com maior número de DEGs. Todos os genes quinases DE aqui encontrados, com exceção de OsMAPK1, estão relacionados diretamente no reconhecimento de patógenos como $X$. oryzae pv. oyzae e $M$. oryzae e alguns deles, como OsMAPK5, são responsivos também a estresses abióticos (Yang et al., 2015; Chandran et al., 2016). A quantidade de genes $M A P K, M A P K K$ e $M A P K K K$ reprimidos aqui encontrados na interação incompatível foram superior aqueles encontrados em outros trabalhos semelhantes (Bagnaresi et al., 2012). 
A maioria dos genes $\mathrm{R}$ a diferentes patógenos foram diferencialmente modulados em AVR. PIBH8 (Os08g42700), gene R a M. oryzae foi reprimido e o gene Os03g14900, cujo produto possui uma região NB-ARC/LRR foi DEG e suprexpresso apenas em plantas induzidas com $M$. oryzae avirulento. Identificação de genes de resistência (R) a diversas doenças é a meta do melhoramento genético para as doenças do arroz e o uso de patógenos avirulentos pode ser útil nessa busca (Drogue et al., 2014). Genes com estruturas motif relacionadas com genes $R$ como quinases, sítio de ligação de nucleotídeo (NBS), região fica em leucina (LRR) e NBS-LRR. foram DEG (Figura 13; anexo tabela 8).

Dentre os tratamentos aqui utilizados AVR foi aquele com menor número de genes DEG relacionados com fitoalexinas. A presença do patógeno avirulento modulou diferencialmente apenas três desses genes. Dentre esses três, os maiores valores de FC foi observado nos dois genes que codificam isoflavonas redutases (Os01g01650 e Os01g01660), (envolvidos na síntese das maaquiaina e medicarpina) O gene OsKO4, envolvido na síntese de momilactona, foi o único DEG em AVR relacionado com fitoalexidas derivadas dos diterpenóides. Esse menor núrmero de genes de fitoalexinas pode ser atribuído a interação incompatível entre planta e patógeno. Fitoalexinas são compostos produzidos após a infecção de plantas por patógenos e neste tratamento não houve infecção (Ahuja et al., 2012).

Algumas proteínas reguladoras envolvendo o cross-talk entre SA e JA em arroz já foram identificadas, dentre elas estão as proteínas NPRs (De Vleesschauwer et al., 2013) que, além desse papel regulador de vias hormonais, também está envolvido em respostas de defesa e indução de resistência (Pajerowska-Mukhtar et al., 2013). O gene OsNPR4 foi reprimido em PGPR, apresentando diferença significativa quando o FC desse tratamentos foi normalizado com VIR.

O gene OsNPR4 foi DEG e reprimido em PGPR e AVR e quando o FC desses tratamentos eram normalizados com VIR, houve diferença significativa nos níveis de expressão, sugerindo que esses dois agentes indutores ativam a expressão diferencial desse gene. Genes NPR codificam proteínas reguladoras envolvendo o cross-talk entre SA e JA. Ele também está envolvido no downstream de processos de indução de resistência, regulando a evolução de SAR e ISR (Pieterse et al., 2014). No presente trabalho, esse gene foi diferencialmente expressos tanto em ISR (aqui desencadeado por Serratia sp.) como em SAR (ativado por M. oryzae avirulento PY10749) 
Dos nove genes diferencialmente expressos em VIR envolvidos vias precursoras e de biossíntese de SA, a maioria deles estão envolvidos na síntese de chiquimato. Apenas dois envolvidos com triptofano e outros dois com SA. (Figura 5; Anexto tabela 2). Talvez isso seja devido a interferência que o fungo faz na planta, usando seus efetores para modular a expressão de SA a seu favor. $M$. oryzae é um patógeno hemibiotrófico. A colonização inicial dos tecidos da hospedeira ocorre biotroficamente. Nesse estilo de colonização, as respostas da planta de arroz governadas por SA são mais efetivas (Talbolt, 2003).

Dentre os tratamentos aqui utilizados, o tratamento VIR, onde plantas de arroz foram desafiadas com $M$. oryzae virulento, foi aquele que apresentou uma maior quantidade de genes superexpressos envolvidos na biossíntese de JA (5) (Figura 6; Anexo tabela 3). A mesma situação se deu com genes DEG responsivos a este hormônio. A maior quantidade de genes dessa classe que foram superexpressos foram encontrados em VIR (Figura 6; Anexo tabela 3). Esses resultados estão de acordo com aqueles encontrados nos capítulos 1 e 3 , onde nos momentos iniciais avaliados, a atividade de LOX, uma enzima chave na biossíntese de JA, foi alta nas plantas apenas desafiadas com M. oryzae virulento (testemunha). Altas concentrações de jasmonatos no início da infecção favorece a colonização dos tecidos infectados, pois JA atua como antagonista do SA; este último hormônio é essencial nas repostas de defesa da planta nos primeiros eventos da interação planta-patógeno. Alta resistência a patógenos necrotróficos é frequentemente correlacionada com um aumento na suscetibilidade à patógenos biotróficos (Robert-Seilaniantz et al., 2011). Isso sugere que patógenos podem modular os genes da hospedeira a seu favor. Uma vez que $M$. oryzae possui os dois tipos de colonização, portanto um patógeno hemibiotrófico, ele libera efetores que regulam a expressão gênica do arroz de modo a facilitar a colonização (Yi \& Valent, 2013).

Quando comparado com os demais tratamentos, VIR apresentou menor quantidade de genes envolvidos na síntese e responsivos a ET (Figura 7; anexo tabela 4). Entretanto, OsACS5 e OsACO7, genes envolvidos na primeira e segunda etapa de biossíntese de ET, apresentaram os maiores de FC em plantas desafiadas com $M$. oryzae virulento. Assim como JA, ET também pode antagonizar SA, favorecendo assim a colonização (Pieterse et al., 2014).

Várias famílias de gene PR foram modulados diferencialmente em VIR. De modo geral, quando comparado aos demais tratamentos, o número de genes foi menor. 
OsPR1b (Os01g28450) cujos produtos são inibidores de proteinases foi DEG apenas em plantas desafiadas com $M$. oryzae virulento, com FC muito superior aos demais tratamentos. Essa é uma proteína básica (Basic PR-1) considerada marcador de respostas de defesa e encontrada em cereais como arroz (Buchel et al., 1999). Seu gene pode ter sido superexpresso em resposta a infecção de $M$. oyzae. Dois genes da família proteica PR10, com atividade de ribonuclease foram superexpressos em VIR: OsPR10 (Os12g36860) OsPR10B (Os12g36850). Esses genes codificam proteínas em resposta a infecções e possuem papel-chave na morte celular programada (Kim et al., 2011). OsPR5 (Os03g45960) que possuem atividade de taumatina e permeabilizam a membrana fúngica, e OsScill, que possui atividade inibidora de proteinase também foram superexpressos em VIR (Figura 8; anexo tabela 5). Plantas tratadas com $M$. oryzae virulento foram aqueles que apresentaram menos genes que codificam $\beta-1,3$ glucanases. PR-2 apresentam atividade de $\beta$-1,3-glucanase, clivando $\beta$-1,3-glucano. A presença do isolado virulento do patógeno não foi tão eficiente quando os outros tratamentos em desencadear a modulação diferencial de genes da família PR-2. A expressão diferencial desses genes pode indicar a ativação de mecanismos de degradação da parece celular de fungos uma vez que esses fitopatógenos possuem $\beta$ 1,3-glucana como constituinte dessa estrutura. Bagnaresi et al. (2012) encontraram um menor número de genes que codificam $\beta$-1,3-glucanase em interações compatíveis no patossitema Oryza sativa-Magnaporthe oryzae. Esses resultados estão de acordo com os resultados de atividade de GLU dos capítulos 2 e 3, onde registrou-se menores atividades dessa enzima nas testemunhas. Outro grupo de genes envolvidos na degradação de produtos contidos na parede celular de fungos foi DEG nas condições aqui avaliadas. Oito genes que codificam quitinases (CHI) foram superexpressos em VIR, entretanto, os seus valores de FC foram menores do que aqueles observados em plantas tratadas com $M$. oryzae avirulento. Resultados semelhantes foram encontrados por Bagnaresi et al. (2012) onde o número de genes CHI em arroz foram menores em interações compatíveis do que em relações incompatíveis com M. oryzae. A presença de $M$. oryzae virulento ativou genes $P O X$, entretanto, não foi tão eficiente quanto outros tratamentos, uma vez que o número desses genes foi menor quando comparado aos outros tratamentos (20 genes). A presença do patógeno virulento (VIR) ativou gene de duas enzimas também envolvidas na explosão oxidativa: OsRbohC e OsRbohH. Esses genes codificam enzimas com a atividade de NADPH oxidase. Na interação com patógenos, a invasão dos tecidos das plantas pelo agente patogênico pode desencadear 
diferentes respostas de defesa da hospedeira; nesses casos, a falta ou a superexpressão de genes RBHO altera a produção de EROs, o que pode ser determinante para condições de suscetibilidade ou de resistência (Denness et al., 2011). Por outro lado, neste tratamento também foi observado vários genes envolvidos no mecanismo antioxidante sendo superexpressos, como os genes OsAOX1a, OsAPX3 e OsAPX7. Uma menor ativação de genes $P O X$ e ativação da maquinaria antioxidante da célula pode ser resultado de efetores do patógeno, modulando esses genes a seu favor, umas vez que a geração de espécies reativas de oxigênio (EROs) pelas POX gera um efeito dominó, ativando outras respostas de defesa (Camejo et al., 2016).

Fatores de transcrição (TF) são proteínas que podem ativar ou reprimir a transcrição em cascata de genes alvo por se ligarem diretamente aos promotores desses genes de maneira específica. O tratamento VIR foi aquele que apresentou menos genes $W R K Y$. Muitos desses genes são genes relacionados a patogênese, envolvidos na indução de diferentes vias sinalizadoras de defesa de plantas e mostram forte respostas transcricional em plantas de arroz sob estresses (Rushton et al., 2010), entretanto os resultados aqui mostrados sugerem que essa família gênica não foi modulada diferencialmente em plantas tratadas com $M$. oryzae virulento.

Proteínas quinases possuem papel importante no reconhecimento e amplificação de sinais e a subsequente ativação de mecanismos de defesa das plantas durante infecções causadas por patógenos. Em VIR, 7 genes que codificam proteínas quinases foram diferencialmente expressos. A maioria desses genes aqui encontrados que foram DE estão relacionados diretamente no reconhecimento de $M$. oryzae e alguns deles, (Yang et al., 2015; Chandran et al., 2016). Proteínas quinases (MAPK, KK e KKK) estão envolvidas no reconhecimento de padrões moleculares associados a patógenos (PAMP), ativando a maquinaria celular de defesa por meio de cascata de sinais (KishiKaboshi et al., 2010; Yang et al., 2015). Um menor número desses genes DEG encontrados em VIR pode levar ao não-ativação de respostas de defesas mais eficientes, facilitando a colonização da planta de arroz por M. oryzae.

O gene PIBH8 (Os08g42700) foi reprimido em VIR. Esse é um gene de resistência a brusone do arroz e a sua repressão pode levar à um aumento da suscetibilidade a $M$. oryzae. Genes $\mathrm{R}$ relacionados a queima bacteriana foram superexpressos apenas nas plantas tratadas com M. oryzae virulento (Figura 13; anexo tabela 8). Os alelos recessivos de OsXA13 e OsXA21 conferem resistência X. oryzae e quando na forma dominante e superexpressos, esses genes conferem suscetibilidade 
tanto a X. oryzae quando a M. oryzae (Peng et al., 2008; Antony et al., 2010), sugerindo que o patógeno modula a expressão desses genes ao seu favor.

Metabólitos secundários de baixo peso molecular com atividade antimicrobiana e induzíveis por estresses são conhecidos como fitoalexinas, possuem papel importante dentre os componentes de defesa de plantas (Ahuja et al., 2012). Vinte e quatro horas após a aplicação dos indutores, dez genes relativos às fitoalexinas foram superexpressos. As fitoalexinas do arroz pertecem ao grupo dos flavonoides e diterpenoides. Muitos DEGs apresentaram diferenças significativas em relação às outras condições (Figura 11; tabela anexo 9). Fitoalexinas são compostos produzidos majoritariamente após o estabelecimento da infecção (Ahuja et al., 2012; Bagnaresi et al., 2012). Isso suporta os resultados aqui apresentados, onde plantas desafiadas com $M$. oryzae tiveram um maior número de genes DEG envolvidos na síntese de fitoalexinas.

Citocromo P450 (P450) são enzimas universais que, por meio da ativação do oxigênio molecular, catalizam uma ampla gama de substratos. Há na literatura diversos trabalhos relacionados com a expressão diferencial de genes P450 induzida por patógenos (Abbruscato et al., 2012; Matic et al., 2016), assim como observado neste trabalho.

Alguns genes que codificam proteínas reguladoras envolvendo o cross-talk entre SA e JA em arroz foram DEG em VIR. SAM (ácido salicílico carboxil metiltransferase, Os06g20960) foi diferencialmente expresso em, sendo também DEG quando os FC dos referidos tratamentos foram normalizados com VIR (Figura 14; anexo tabela 11). Ele codifica uma enzima que, além de atuar na conversão de SA em metil-salicilato, também pode agir em outros substratos, como JA, podendo ser um mediador entre as vias desses hormônios (Ogawa et al., 2001). A superexpressão do gene SLR1 (DELLA protein Slender Rice 1) confere resistência ao arroz contra brusone foliar por meio da amplificação e integração das vias sinalizadoras envolvendo SA e JA (De Vleesschauwer et al., 2016). O gene OsSLRI foi DEG e reprimido apenas nas plantas desafiadas com $M$. oryzae virulento, sugerindo ter sido modulado pelo patógeno para favorecer a infecção. 


\section{CONCLUSÃO}

Este trabalho apresentou informações inéditas de estudos comparativos entre trascriptomas obtidos de plantas de arroz induzidas por diferentes microrganismos indutores.

O conjunto amplo de genes diferencialmente expressos observados mostrou que há variações nas respostas de defesa da planta quando induzida com diferentes agentes indutores, embora haja semelhanças entre as vias metabólicas por eles ativadas.

A rizobactéria Serratia sp. desencadeou ISR modulando de forma diferencial genes da biossíntese de SA e aumento na atividade de várias PRPs. M. oryzae avirulento PY10749 ativou SAR principalmente superexpressando genes POX, GLU e CHI. O isolado de M. oryzae virulento PY10900 interferiu na expressão diferencial de genes importantes da planta de arroz, modulando-os a seu favor.

Muitos transcritos encontrados neste trabalho podem ser utilizado como marcadores de indução das respostas de defesa associados com seu respectivo agente indutor. Estudos posteriores mais detalhado desses genes podem abastecer os bancos de fontes de resistência do melhoramento de cultivares visando o controle sustentável de diversas doenças dessa cultura. 


\section{LITERATURA CITADA}

ABBRUSCATO, P.; NEPUSZ, T.; MIZZI, L.; DEL CORVO, M.; MORANDINI, P.; FUMASONI, I.; MICHEL, C.; PACCANARO, A.; GUIDERDONI, E.; SCHAFFRATH, U.; MOREL, JB.; PIFFANELLI, P. \& FAIVRE-RAMPANT, O. 2012. OsWRKY22, a monocot WRKY gene, plays a role in the resistance response to blast. Molecular Plant Pathology 13:828-841.

AHUJA, I.; KISSEN, R. \& BONES, A.M. 2012. Phytolaexins in defense against pathogens. Trends in Plant Science 17:73-90.

ANTONY, G.; ZHOU, J.; HUANG, S.; LI, T.; LIU, B.; WHITE, F. \& YANG, B. 2010. Rice $x a 13$ recessive resistance to bacterial blight is defeated by introduction of the disease susceptibility gene Os-11N3. The Plant Cell 1-13. DOI 10.1105/tpc.110.078964.

BAGNARESI, P.; BISELLI, C.; ORRÙ, L.; URSO, S.; CRISPINO, L.; ABBRUSCO, P.; PIFFANELli, P.; LUPOTTO, E.; CATTIVELli, L. \& VALE, G. 2012. Comparative transcriptome profiling of the early response to Magnaporthe oryzae in durable resistant vs susceptible rice (Oryza sativa L.) genotypes. Plos One 7:e51609.

BOLLER, T. \& FELIX, G. 2009. A renaissance of elicitors: perception of microbeassociated molecular patterns and danger signals by pattern-recognition receptors. Annual Review of Plant Biology 60:379-406.

BUCHEL, A.S.; BREDERODE, F.T.; BOL, J.F.; LINTHORST, H.J. 1999. Mutation of GT-1 binding sites in the Pr-1 A promoter influences the level of inducible gene expression in vivo. Plant Molecular Biology 40:387-396.

CAMEJO, D.; GUZMÁN-CEDEÑO, A. \& MORENO, A. 2016. Reactive oxygen species, essential molecules, during plant-pathogen interactions. Plant Physiology and Biochemistry 103:10-23. 
CHANDRAN, A.K.N.; YOO, YH.; CAO, P.; SHARMA, R.; SHARMA, M.; CHRISTOPER, D.; RONALD, P. \& JUNG, KH. 2016. Updated Rice Kinase Database RKD 2.0: enabling transcriptome and functional analysis of rice kinase genes. Rice 9:40.

DENNESS, L.; MCKENNA, J.F.; SEGONZAC, C.; WORMIT, A.; MADHOU, P.; BENNETT, M.; MANSFIELD, J.; ZIPFEL, C. \& HAMANN, T. 2011. Cell wall damage-induced lignin biosynthesis is regulated by a reactive oxygen speciesand jasmonic acid dependent process in Arabidopsis. Plant Physiology 156:1364-1374.

DROGUE, B.; SANGUIN, H.; CHAMAM, A.; MOZAR, M.; LLAURO, C.; PANAUD, O.; PRINGENT-COMBARET, C.; PICAULT, N. \& WINIEWSKI-DYE, F. 2014. Plant root transcriptome profiling reveals a strain-dependent response during Azospirillum-rice cooperation. Frontiers in Plant Science 5:607.

FERREIRA，R.B.; MONTEIRO, S.; FREITAS, R.; SANTOS, C.N.; CHEN, Z.; BATISTA, L.M.; BORGES, A. \& TEIXEIRA, A.R. 2007. The role of plant defense proteins in fungal pathogenesis. Molecular Plant Pathology 8:677-700.

FILIPPI, M.C., PRABHU, A.S., 2001. Phenotypic virulence analysis of Pyricularia grisea isolates from Brazilian upland rice cultivars. Pesquisa Agropecuária Brasileira 36: 27-35.

FILIPPI, MARTA C.C.; SILVA, GISELE B. \& PRABHU, ANNE S. 2007. Indução de resistência à brusone em folhas de arroz por isolado avirulento de Magnaporthe oryzae. Fitopatologia Brasileira 32:387-392.

FILIPPI, M.C.C.; SILVA; G.B.; SILVA-LOBO, V.L.; CÔRTES, M.V.C.B.; MORAES; A.J.G. \& PRABHU, A.S., 2011. Leaf blast (Magnaporthe oryzae) suppression and growth promotion by rhizobacteria on aerobic rice in Brazil. Biological Control, 58:160-166. 
GARCÍA-CRISTOBAL, J.; GARCÍA-VILLARACO, A.; RAMOS, B.; GUTIERREZMAÑERO, J.; LUCAS, J.A. 2015. Primming of pathogenesis related-proteins and enzymes related to oxidative stress by plant growth promoting rhizobacteria on rice plants upon abiotic and biotic stress challenge. Journal of Plant Physiology 188:72-79.

GORDON-WEEKS, R.; SUGARS, J.M.; ANTONIUW, J.F. \& WHITE, R.F. 1997. Accumulation of novel PR1 proteins in Nicotiana leaves in response to virus infection or treatment with salicylic acid. Physiological and Molecular Plant Pathology 50:263-273

ISHIGA, Y.; ISHIGA, T.; UPPALAPATI, S.R. \& MYSORE, K.S. 2013. Jasmonate ZIM-Domain (JAZ) protein regulates host and nonhost pathogen-induced cell death in tomato and Nicotiana benthamiana. Plos One 8(9):e75728.

KAWAHARA, Y.; OONO, Y.; KANAMORI, H.; MATSUMOTO, T.; ITOH, T. \& MINAMI, E. 2012. Simultaneous rna-seq analysis of a mixed transcriptome of rice and blas fungus interaction. Plos One, 7(11):e49423.

KHUSH, G.S. 2005. What it will take to feed 5.0 billion rice consumers in 2030. Plant Molecular Biology 59:1-6.

KIM, S.G.; KIM, S.T.; WANG, Y.; YU, S.; CHOI, I.S.; KIM, Y.C.; KIM, W.T.; AGRAWAL, G.J.; RAKWAL, R. \& KANG, K.Y. 2011. The RNase activity of rice Probenazole-Induced Protein 1 (PBZ1) plays a key role in cell death in plants. Molecules and Cells 31:25-31.

KIM, S.T.; KANG, Y.H.; WANG, Y.; WU, J.; PARK, Z.Y.; RAKWAL, R.; AGRAWAL, G.K.; LEE, S.Y. \& KANG, K.Y. 2009. Secretome analysis of differentially induced proteins in rice suspension-cultured cells triggered by rice blast fungus and elicitor. Proteomics 9:1302-1313.

KISHI-KABOSHI, M.; OKADA， K.; KURIMOTO, L.; MURAKAMI, S.; UMEZAWA, T.; SHIBUYA, N.; YAMANE, H.; MIYAO, A.; TAKATSUJI, H.; 
TAKAHASHI, A. \& HIROCHIKA, H. 2010. A rice fungal MAMP-responsive MAPK cascade regulates metabolic flow to antimicrobial metabolite synthesis. The Plant Journal 63:599-612.

KOUZAI, Y.; KIMURA, M.; YAMANAKA, Y.; WATANABE, M.; MATSUI, H.; YAMAMOTO, M.; ICHINOSE, Y.; TOYODA, K.; ONDA, Y.; MOCHIDA, K. \& NOUTOSHI, Y. 2016. Expression profiling of marker genes responsive to the defense-associated phytohormones salicylic acid, jasmonic acid and ethylene in Brachypodium distachyon. BMC Plant Biology 16:59.

KURABACHEW, H.; STAHL, F. \& WYDRA, K. 2013. Global gene expression of rhizobacteria-silicon mediated induced systemic resistance in tomato (Solanum lycopersicum) against Ralstonia solanacearum. Physiological and Molecular Plant Pathology 84:44-52.

LIU, Z.; ZHANG, S.; SUN, N.; LIU, H.; ZHAO, Y.; LIANG, Y.; ZHANG, L. \& HAN, Y. 2015. Functional diversity of jasmonates in rice. Rice 8:5:1-13.

MAEDA, H. \& DUDAREVA, N. 2012. The Shikimate pathway and aromatic amino acid biosynthesis in plants. Annual Review of Plant Biology 63:73-105.

MATIC, S.; BAGNARESI, P.; BISELli, C.; ORRU, L.; CARNEIRO, G.A.; SICILIANO, I.; VALE, G.; GULLINO, M.L. \& SPADARO, D. 2016. Comparative transcriptome profiling of resistant and susceptible rice genotypes in response to the seedborne pathogen Fusarium fujikuroi. BMC Genomics 17:608.

MERSMANN, S.; BOURDAIS, G.; RIETZ, S. \& ROBATZEK S. 2010. Ethylene signaling regulates accumulation of the FLS2 receptor and is required for the oxidative burst contributing to plant immunity. Plant Physiology 154:391-400.

MINIC, Z. 2008. Physiological roles of plant glycoside hydrolases. Planta. 227:723-40. 
MONTEIRO, S.; BARAKAT, M.; PIÇARRA-PEREIRA, M.A.; TEIXEIRA, A.R. \& FERREIRA, R.B. 2003. Osmotin and thaumatin from grape: a putative general defense mechanism against pathogenic fungi. Phytopathology, 93:1505-1512.

OGAWA, M.; HERAI, Y.; KOIZUMI, N.; KUSANO, T. \& SANO, H. 2001. 7Methylxanthine Methyltransferase of coffee plants. The Journal of Biological Chemistry 276:8213-8218.

PAJEROWSKA-MUKHTAR, K.M.; EMERINE, D.K. \& MUKHTAR, M.S. 2013. Tell me more: roles of NPRs in plant immunity. Trends in Plant Science 7:402-411.

PENG, Y.; BARTLEY, L.E.; CHEN, X.; DARDICK, C.; CHERN, M.; RUAN, R.; CANLAS, P.E. \& RONALD, PC. 2008. OsWRKY62 is a negative regulator of basal and Xa21-mediated defense against Xanthomonas oryzae pv. oryzae in rice. Molecular Plant 1:446-458.

PIETERSE, C.M.J.; ZAMIOUDIS, C.; BERENDSEN, R.L.; WELLER, D.M.; Van WEES, S.C.M. \& BAKKER, P.A.H.M. 2014. Induced systemic resistance by beneficial microbes. Annual Review of Phytopathology 52:347-375.

POUPIN, M.J.; TIMMERMANN, T.; VEGA, A.; ZUÑIGA, A. \& GONZÁLEZ, B. 2013. Effects of the plant growth-promoting bacteria, Burkholderia phytofirmans PsJN throughout the life cycle of Arabidopsis thaliana. Plos One 8(7):e69435.

RAJ, S.N.; LAVANYA, S.N.; AMRUTHESH, K.N.; NIRANJANA, S.R.; REDDY, M.S. \& SHETTY, H.S. 2012. Histo-chemical changes induced by PGPR during induction of resistance in pearl millet against downly mildew disease. Biological Control, 60:90-102.

RIECHMANN, J.M. \& MEYEROWITZ, E.M. 1998. The AP2/EREBP family of plant transcription factors. Biological Chemistry 379:633-646. 
ROBERT-SEILANIANTZ, A.; GRANT, M. \& JONES, J.D.G. 2011. Hormone crosstalk in plant disease and defense: more than just JASMONATESALICYLATE antagonism. Annual Review of Phytopathology, 49:317-343.

RUSHTON, P.J.; SOMSSICH, I.E.; RINGLER, P. \& SHEN, Q.J. 2010. WRKY transcription factors. Trends in Plant Science 15:247-58.

RZEWUSKI, G. \& SAUTER, M. 2008. Ethylene biosynthesis and signaling in rice. Plant Science 175:32-42.

STEARNS, J.C.; WOODY, O.Z.; MCCONKEY, B.J. \& GLICK, B.R. 2012. Effects of bacterial ACC deaminase on Brassica napus gene expression. Molecular Plant Microbe Interactions 25:668-676.

SCHWESSINGER, B. \& ZIPFEL, C. 2008. News from the frontline: recent insights into PAMP-triggered immunity in plants. Current Opinion in Plant Biology, 11:389-395.

TALBOT, N.J. 2003. On the trail of a cereal killer: Exploring the biology of Magnaporthe grisea. Annual review of microbiology 57: 177-202.

TONG, X.; QI, J.; ZHU, X.; MAO, B.; ZENG, L.; WANG, B.; LI, Q.; ZHOU, G., XU, X.; LOU, Y.; HE, Z. 2012. The rice hydroperoxide lyase OsHPL3 functions in defense responses by modulating the oxylipin pathway. Plant Journal 71:763775 .

VILA, L.; QUILIS, J.; MEYNARD, D.; BREITLER, J.C.; MARFA, V.; MURILLO, I.; VASSAL, J.M.; MESSENGUER, J.; GUIDERDONI, E. \& SAN SEGUNDO, E. 2005. Expression of the maize proteinase inhibitor (mpi) gene in rice plants enhances resistance against the striped stem borer (Chilo suppressalis): effects on larval growth and insect gut proteinases. Plant Biotechnology Journal 3:187202. 
De VLEESSCHAUWER, D.; GHEYSEN, G. \& HOFTE, M. 2013. Hormone defense networking in rice: tales from a different world. Trends in Plant Science 18:555565.

De VLEESSCHAUWER, D.; SEIFI, H.S.; FILIPE, O.; HAECK, A.; HUU, S.N.; DEMEESTERE, K. \& HOFE, M. 2016. The DELLA protein SLR1 integrates and amplifies salicylic acid- and jasmonic acid-dependent innate immunity in rice. Plant Physiology 170:1831-1847.

YANG, Z.; MA, H.; HONG, H.; YAO, W.; XIE, W.; XIAO, J.; LI, X. \& WANG, S. 2015. Transcriptome-based analysis of mitogen-actived protein kinase cascades in the rice response to Xanthomonas oryzae infection. Rice 8:4.

YI, M.; VALENT, B. 2013. Communication between filamentous pathogens and plants at the biotrophic interface. Annual Review of Phytopathology 51: 587-611.

ZHANG J, PENG Y, GUO Z. 2008. Constitutive expression of pathogen-inducible OsWRKY31 enhances disease resistance and affects root growth and auxin response in transgenic rice plants. Cell Research 18: 508-521 


\section{CONSIDERAÇÕES FINAIS}

Os resultados aqui apresentados foram importantes para descrever como diferentes agentes, bióticos e abióticos, desencadeiam indução de resistência de forma sistêmica. O patossistema Oryza sativa-Magnaporthe oryzae é intensamente estudado e considerado um modelo para estudo em interação planta-patógeno, gerando muitas publicações. Entretanto, este trabalho foi o primeiro a comparar as vias de defesa na indução e suas interações.

Nos resultados obtidos foi possível observar a influência dos agentes indutores nas respostas de defesa e a interação entre essas respostas. A rizobactéria Serratia sp. BRM32114 promoveu crescimento das plantas de arroz e reduziu o progresso da doença. O balanço das repostas de defesa foi feito pela interação entre ácido salicílico e lipoxigenase (LOX) (enzima envolvida na síntese de ácido jasmônico).

A ativação das defesas da planta por isolado avirulento antes do desafio com $M$. oryzae virulento possibilitou resposta imune efetiva, não permitindo o estabelecimento da infecção. Os resultados indicam que houve um rápido reconhecimento do patógeno pela planta, envolvendo explosão oxidativa seguida do aumento na produção de proteínas relacionadas à patogênese e modificações histológicas que culminaram em respostas de hipersensibilidade (HR).

A aplicação exógena do ativador sintético acibenzolar-S-metil desencadeou respostas de defesa da planta semelhante à resposta ao isolado avirulento de $M$. oryzae, com a formação de sintomas de hipersensibilidade e altos níveis de peroxidase (POX). A aplicação de JA como agente indutor desencadeou uma suscetibilidade sistêmica das plantas de arroz que apresentaram alta severidade de brusone foliar. Esse elevado índice de doença esta relacionada com os altos valores de atividade LOX nas horas iniciais da infecção, uma vez que favoreceu a colonização dos tecidos foliares pelo patógeno. Quando JA e ASM foram aplicados em conjunto, as plantas apresentaram menor SBF do que as plantas que foram tratadas apenas com JA e maior área do que nas plantas induzidas com ASM, indicando o efeito antagônico entre ambos.

Finalmente, como observado nos outros capítulos, os genes que foram modulados diferencialmente nas plantas de arroz mostraram que há diferenças nas vias sinalizadoras bem como nas respostas de defesa desencadeadas por Serratia sp. e isolados AVR e VIR de M. oryzae. 
As informações aqui reveladas demonstram que as interações das respostas imunes não são pontuais, onde muitos "atores" estão envolvidos e são capazes de mediar a comunicação com os indutores e também entre as rotas sinalizadoras. Desvendar o efeito cruzado das vias hormonais e os genes responsivos a elas servirão para determinar suas funções e potencializar os mecanismos envolvidos na relação benéfica entre agentes indutores e plantas. 


\section{$\underline{\text { ANEXOS }}$}


Tabela 1. Oligos utilizados na validação dos dados de RNAseq via qRT-PCR.

\begin{tabular}{|c|c|c|c|}
\hline Nome do oligonucleotídeo & Sequência & $\begin{array}{l}\text { Escala de } \\
\text { síntese }\end{array}$ & Purificação \\
\hline LOC_Os01g61990_NPR4_F & GCAACTATCTCTGCTCGCTTTTT & $25 \mathrm{~N}$ & Dessalinizado \\
\hline LOC_Os01g61990_NPR4_R & CACTTGTCGACGCTGATCCA & $25 \mathrm{~N}$ & Dessalinizado \\
\hline LOC_Os05g01140_JMT1_F & CCGAAGTGTGGTCCAAGCA & $25 \mathrm{~N}$ & Dessalinizado \\
\hline LOC_Os05g01140_JMT1_R & CCCGCTCATGCCAATCC & $25 \mathrm{~N}$ & Dessalinizado \\
\hline LOC_Os06g20960_SAM_F & TGCACTATTGCTGGCTCGAA & $25 \mathrm{~N}$ & Dessalinizado \\
\hline LOC_Os06g20960_SAM_R & CGATGGCCCACGATACTTTC & $25 \mathrm{~N}$ & Dessalinizado \\
\hline LOC_Os02g54600_MAPKK4_F_N & CCCACAATTTGCAGAATCCA & $25 \mathrm{~N}$ & Dessalinizado \\
\hline LOC_Os02g54600_MAPKK4_R_N & GGTGTCCATCTGCTCCAGTTG & $25 \mathrm{~N}$ & Dessalinizado \\
\hline LOC_Os01g53260_WRKY31_F_N & TCCCAGTTCTAATTAACGACCCATA & $25 \mathrm{~N}$ & Dessalinizado \\
\hline LOC_Os01g53260_WRKY31_R_N & TGTGTGTTATTGTGTTTGTGTAGTAACTTG & $25 \mathrm{~N}$ & Dessalinizado \\
\hline LOC_Os01g61080_WRKY22_F_N & CCAGAACTCGCTCTACTGACTGAA & $25 \mathrm{~N}$ & Dessalinizado \\
\hline LOC_Os01g61080_WRKY22_R_N & ACGTACAAGTACAAAACCCCCCTAA & $25 \mathrm{~N}$ & Dessalinizado \\
\hline LOC_Os06g16350_PRX77_F & CCAGCTCGAACCCCTTCAG & $25 \mathrm{~N}$ & Dessalinizado \\
\hline LOC_Os06g16350_PRX77_R & CAGGGTTGCGATGGATCAGT & $25 \mathrm{~N}$ & Dessalinizado \\
\hline LOC_Os11g10460_PRX132_F & GTTGTTCACCTCCGCGTTATTC & $25 \mathrm{~N}$ & Dessalinizado \\
\hline LOC_Os11g10460_PRX132_R & CCCCGCCCTTGTTCGT & $25 \mathrm{~N}$ & Dessalinizado \\
\hline LOC_Os09g32080_CHIT13_F & GTGAGGAGCTGTGGTTTGCA & $25 \mathrm{~N}$ & Dessalinizado \\
\hline LOC_Os09g32080_CHIT13_R & CAАCAААТTТСССАААТСССАТА & $25 \mathrm{~N}$ & Dessalinizado \\
\hline LOC_Os06g37300_KO4_F & TTCAGTTGAATTGAGCACAACCA & $25 \mathrm{~N}$ & Dessalinizado \\
\hline LOC_Os06g37300_KO4_R & GAAGCCTCATCAGACGTTTGC & $25 \mathrm{~N}$ & Dessalinizado \\
\hline LOC_Os08g42700_PIBH8_F & GGGAAAACCACTCTCGTCAAAA & $25 \mathrm{~N}$ & Dessalinizado \\
\hline LOC_Os08g42700_PIBH8_R & GCTGGAAAGGACGCAATACAG & $25 \mathrm{~N}$ & Dessalinizado \\
\hline LOC_Os05g36290_Sim-Actin1_F & GCAAAACCTGCCTTGACCAT & $50 \mathrm{~N}$ & Dessalinizado \\
\hline LOC_Os05g36290_Sim-Actin1_R & GCCTCGTCAAGCAGAAGCA & $50 \mathrm{~N}$ & Dessalinizado \\
\hline LOC_Os01g22490_UBQ5_F & AGGTGTTCAGTTCCAAGGAGACTAG & $50 \mathrm{~N}$ & Dessalinizado \\
\hline LOC_Os01g22490_UBQ5_R & GGAAGTAAGGAAGGAGGAGGAAAT & $50 \mathrm{~N}$ & Dessalinizado \\
\hline
\end{tabular}


TABELA 2. Genes diferencialmente expressos (DEG) relacionados com ácido salicílico (SA).

\begin{tabular}{|c|c|c|c|c|c|c|c|c|c|c|c|c|c|c|}
\hline & \multirow[b]{2}{*}{ Anotação } & \multirow[b]{2}{*}{ Gene ID } & \multicolumn{2}{|c|}{$\mathrm{H} 2 \mathrm{O}-\mathrm{AVR}$} & \multicolumn{2}{|c|}{ H2O-PGPR } & \multicolumn{2}{|c|}{$\mathrm{H} 2 \mathrm{O}-\mathrm{VIR}$} & \multicolumn{2}{|c|}{ AVR-PGPR } & \multicolumn{2}{|c|}{ AVR-VIR } & \multicolumn{2}{|c|}{ PGPR-VIR } \\
\hline & & & DEG & $\mathrm{FC}$ & DEG & $\mathrm{FC}$ & DEG & $\mathrm{FC}$ & DEG & $\mathrm{FC}$ & DEG & $\mathrm{FC}$ & DEG & $\mathrm{FC}$ \\
\hline \multirow{6}{*}{ 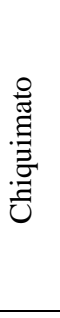 } & DHQDT/SDH shikimate dehydrogenase & LOC_Os01g27750 & yes & 1,4955 & no & 1,0718 & yes & 1,5790 & no & $-0,4237$ & no & 0,0836 & no & 0,5073 \\
\hline & OsDAHP1 & LOC_Os07g42960 & yes & 1,0945 & no & 0,4260 & yes & 1,2289 & no & $-0,6685$ & no & 0,1344 & no & 0,8029 \\
\hline & OsDAHPS1 & LOC_Os03g27230 & yes & 2,3533 & yes & 1,8502 & yes & 2,0133 & no & $-0,5031$ & no & $-0,3399$ & no & 0,1631 \\
\hline & OsEPSPS 5 & LOC_Os06g04280 & yes & 1,3747 & yes & 0,9372 & yes & 1,3753 & no & $-0,4375$ & no & 0,0005 & no & 0,4381 \\
\hline & OsSK3 Shikimate kinase & LOC_Os04g54800 & yes & 1,7678 & yes & 1,3184 & yes & 1,3831 & no & $-0,4494$ & no & $-0,3846$ & no & 0,0647 \\
\hline & Shikimate kinase CS domain & LOC_Os10g42700 & yes & 1,1290 & no & 0,3283 & no & 0,8171 & no & $-0,8007$ & no & $-0,3119$ & no & 0,4888 \\
\hline \multirow{4}{*}{ 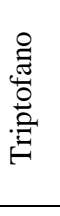 } & Aminodeoxychorismate synthase & LOC_Os06g48620 & no & $-0,8263$ & yes & $-1,0627$ & no & $-0,5560$ & no & $-0,2363$ & no & 0,2703 & no & 0,5066 \\
\hline & Anthranilate phosphoribosyltransferase & LOC_Os05g30750 & yes & 2,3037 & yes & 1,7243 & yes & 1,9967 & no & $-0,5794$ & no & $-0,3070$ & no & 0,2724 \\
\hline & OsASA1 Anthranilate synthase & LOC_Os03g61120 & yes & 1,2109 & no & 0,7846 & no & 0,7243 & no & $-0,4263$ & no & $-0,4866$ & no & $-0,0603$ \\
\hline & Indol-3-glicerol fosfato-liase & LOC_Os03g58320 & yes & $-1,1204$ & no & $-0,2119$ & yes & $-1,0075$ & no & 0,9086 & no & 0,1129 & no & $-0,7957$ \\
\hline \multirow{4}{*}{ 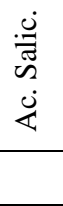 } & OsPAL01 Phenylalanine ammonia-lyase & LOC_Os02g41680 & no & 0,8633 & yes & 0,8639 & no & 0,8125 & no & 0,0006 & no & $-0,0508$ & no & $-0,0514$ \\
\hline & OsPAL02 Phenylalanine ammonia-lyase & LOC_Os04g43760 & yes & 1,5155 & yes & 1,3283 & yes & 1,1447 & no & $-0,1872$ & no & $-0,3709$ & no & $-0,1836$ \\
\hline & OsPAL08 Phenylalanine ammonia-lyase & LOC_Os02g41650 & no & 1,3061 & yes & 1,2578 & yes & 1,0807 & no & $-0,0484$ & no & $-0,2254$ & no & $-0,1770$ \\
\hline & OsSGT salicylic acid glucosyltransferase & LOC_Os09g34250 & no & 0,8895 & yes & 1,2049 & no & 0,8951 & no & 0,3153 & no & 0,0055 & no & $-0,3098$ \\
\hline
\end{tabular}

FC: fold change. 
TABELA 3. Genes diferencialmente expressos (DEG) relacionados com ácido jasmônico (JA).

\begin{tabular}{|c|c|c|c|c|c|c|c|c|c|c|c|c|c|c|}
\hline & \multirow[b]{2}{*}{ Anotação } & \multirow[b]{2}{*}{ Gene ID } & \multicolumn{2}{|c|}{ H2O-AVR } & \multicolumn{2}{|c|}{ H2O-PGPR } & \multicolumn{2}{|c|}{ H2O-VIR } & \multicolumn{2}{|c|}{ AVR-PGPR } & \multicolumn{2}{|c|}{ AVR-VIR } & \multicolumn{2}{|c|}{ PGPR-VIR } \\
\hline & & & DEG & $\mathrm{FC}$ & DEG & $\mathrm{FC}$ & DEG & $\mathrm{FC}$ & DEG & $\mathrm{FC}$ & DEG & $\mathrm{FC}$ & DEG & FC \\
\hline \multirow{14}{*}{ 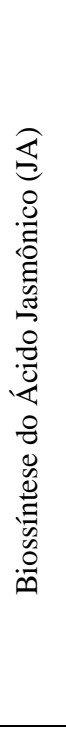 } & Oryzain beta chain precursor & LOC_Os04g57440 & no & 0,877782 & yes & 0,932404 & no & 0,679451 & no & 0,0546217 & no & $-0,198331$ & no & $-0,25295$ \\
\hline & OsAOS1 Allene oxide synthase & LOC_Os03g55800 & yes & $-1,7554$ & yes & $-2,02794$ & yes & $-1,26698$ & no & $-0,272533$ & no & 0,488425 & no & 0,760957 \\
\hline & OsAOS2 Allene oxide synthase & LOC_Os03g12500 & no & 1,37845 & yes & 1,51736 & yes & 1,79591 & no & 0,138918 & no & 0,417469 & no & 0,27855 \\
\hline & OsLOX1 Lipoxygenase & LOC_Os03g49380 & no & 0,883937 & no & 0,712633 & yes & 1,0223 & no & $-0,171304$ & no & 0,138363 & no & 0,309668 \\
\hline & LOX Lipoxygenase 2.2 & LOC_Os12g37320 & yes & $-1,97853$ & no & $-1,46404$ & no & $-1,48164$ & no & 0,51449 & no & 0,496889 & no & $-0,0176$ \\
\hline & OsLOX11 Lipoxygenase & LOC_Os12g37260 & yes & $-1,93237$ & no & $-1,14921$ & no & $-1,21423$ & no & 0,783159 & no & 0,718134 & no & $-0,06502$ \\
\hline & OsLOX12 Lipoxygenase & LOC_Os12g37350 & yes & $-1,82876$ & yes & $-1,09099$ & yes & $-1,2089$ & no & 0,737775 & no & 0,619867 & no & $-0,11791$ \\
\hline & OsLOX2 Lipoxygenase & LOC_Os08g39840 & yes & $-1,87369$ & yes & $-1,82077$ & no & $-0,766901$ & no & 0,0529223 & yes & 1,10679 & yes & 1,05387 \\
\hline & OsLOX6 Lipoxygenase & LOC_Os04g37430 & yes & $-1,41429$ & yes & $-1,68323$ & no & $-0,705941$ & no & $-0,268943$ & no & 0,708349 & no & 0,977293 \\
\hline & OsLOX8 Lipoxygenase & LOC_Os08g39850 & yes & 1,28537 & no & 1,12376 & yes & 1,27643 & no & $-0,161611$ & no & $-0,00894102$ & no & 0,15267 \\
\hline & OsOPR1 & LOC_Os06g11290 & yes & 1,27143 & no & 0,623613 & yes & 1,75194 & no & $-0,647819$ & no & 0,480512 & yes & 1,12833 \\
\hline & OsRPL12-2 & LOC_Os01g47330 & yes & 0,996576 & no & 0,326807 & no & 0,609515 & no & $-0,669769$ & no & $-0,387061$ & no & 0,282708 \\
\hline & Phospholipase A2 & LOC_Os01g40070 & yes & $-1,75366$ & yes & $-1,28497$ & yes & $-1,25481$ & no & 0,468682 & no & 0,498845 & no & 0,030163 \\
\hline & Phospholipase A2 & LOC_Os03g50030 & yes & 2,12316 & yes & 1,76966 & yes & 2,11601 & no & $-0,353504$ & no & $-0,00714608$ & no & 0,346358 \\
\hline \multirow{10}{*}{ 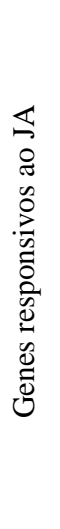 } & Enoyl-CoA hydratase & LOC_Os01g47350 & yes & 1,62151 & yes & 1,16846 & yes & 1,19091 & no & $-0,453054$ & no & $-0,430605$ & no & 0,022449 \\
\hline & Lecithin-cholesterol acyltransferase & LOC_Os02g37800 & yes & 1,9973 & yes & 1,62653 & yes & 2,10334 & no & $-0,370761$ & no & 0,106049 & no & 0,47681 \\
\hline & OsbHLH148 & LOC_Os03g53020 & yes & $-2,33398$ & yes & $-2,58574$ & yes & $-1,21784$ & no & $-0,251763$ & yes & 1,11614 & yes & 1,3679 \\
\hline & OsbHLH6, RERJ1 & LOC_Os04g23550 & yes & $-3,19871$ & yes & $-3,25805$ & yes & $-1,72405$ & no & $-0,0593459$ & yes & 1,47465 & yes & 1,534 \\
\hline & OsFAD7W-3 fatty acid desaturase & LOC_Os03g18070 & yes & $-1,20056$ & yes & $-2,29879$ & no & $-0,609845$ & yes & $-1,09823$ & no & 0,590717 & yes & 1,68894 \\
\hline & OsHPL3 Hydroperoxide lyase & LOC_Os02g02000 & yes & $-1,52089$ & yes & $-1,36349$ & yes & $-1,57421$ & no & 0,157394 & no & $-0,0533237$ & no & $-0,21072$ \\
\hline & OsJAC1 jacalin-related lectin & LOC_Os12g14440 & yes & $-4,14152$ & yes & $-1,66899$ & yes & $-1,79616$ & yes & 2,47253 & yes & 2,34536 & no & $-0,12717$ \\
\hline & OsJAZ12 & LOC_Os10g25290 & yes & $-1,42106$ & yes & $-1,60017$ & no & $-0,698766$ & no & $-0,179108$ & no & 0,722295 & no & 0,901403 \\
\hline & OsJAZ13 & LOC_Os10g25230 & yes & $-5,6665$ & yes & $-5,22021$ & yes & $-2,92285$ & no & 0,446289 & yes & 2,74365 & yes & 2,29736 \\
\hline & OsJAZ3 & LOC_Os03g08310 & yes & $-2,15691$ & yes & $-2,07221$ & no & $-0,587665$ & no & 0,084698 & yes & 1,56924 & yes & 1,48455 \\
\hline
\end{tabular}




\begin{tabular}{|c|c|c|c|c|c|c|c|c|c|c|c|c|c|}
\hline OsJAZ4 & LOC_Os03g08330 & yes & $-3,26719$ & yes & $-3,26477$ & yes & $-1,33316$ & no & 0,00242113 & yes & 1,93403 & yes & 1,9316 \\
\hline OsJAZ5 & LOC_Os03g28940 & yes & $-1,056$ & yes & $-1,32533$ & no & $-0,56464$ & no & $-0,269324$ & no & 0,491364 & no & 0,760688 \\
\hline OsJMT1 & LOC_Os05g01140 & yes & 2,68811 & yes & 2,77915 & yes & 2,63175 & no & 0,0910449 & no & $-0,0563578$ & no & $-0,1474$ \\
\hline OsMYC2 & LOC_Os10g42430 & yes & $-1,17301$ & yes & $-0,986484$ & no & $-0,890457$ & no & 0,186525 & no & 0,282552 & no & 0,096027 \\
\hline OsSLRL1 & LOC_Os01g45860 & yes & 1,99366 & no & 1,64973 & no & 1,68309 & no & $-0,343939$ & no & $-0,310578$ & no & 0,033361 \\
\hline OsTHI32 Thionin & LOC_Os09g24350 & yes & 1,77558 & yes & 2,24052 & no & 1,27576 & no & 0,464937 & no & $-0,499823$ & no & $-0,96476$ \\
\hline phospholipase C & LOC_Os03g30130 & yes & 1,77609 & yes & 1,53564 & yes & 1,62329 & no & $-0,240458$ & no & $-0,152807$ & no & 0,087651 \\
\hline phospholipase C & LOC_Os05g 03610 & yes & 2,39088 & yes & 1,89142 & yes & 1,93933 & no & $-0,499461$ & no & $-0,451554$ & no & 0,047907 \\
\hline phospholipase C & LOC_Os08g01310 & yes & 1,67094 & yes & 1,40877 & yes & 1,68506 & no & $-0,262174$ & no & 0,0141139 & no & 0,276288 \\
\hline RERJ1 & LOC_Os01g09620 & yes & 1,50857 & yes & 1,70203 & no & 0,31214 & no & 0,193454 & Yes & $-1,19643$ & yes & $-1,38988$ \\
\hline
\end{tabular}

FC: fold change. 
TABELA 4. Genes diferencialmente expressos (DEG) relacionados com Etileno (ET).

\begin{tabular}{|c|c|c|c|c|c|c|c|c|c|c|c|c|c|c|}
\hline & \multirow[b]{2}{*}{ Anotação } & \multirow[b]{2}{*}{ Gene ID } & \multicolumn{2}{|c|}{ H2O-AVR } & \multicolumn{2}{|c|}{ H2O-PGPR } & \multicolumn{2}{|c|}{ H2O-VIR } & \multicolumn{2}{|c|}{ AVR-PGPR } & \multicolumn{2}{|c|}{ AVR-VIR } & \multicolumn{2}{|c|}{ PGPR-VIR } \\
\hline & & & DEG & FC & DEG & FC & DEG & FC & DEG & FC & DEG & FC & DEG & $\mathrm{FC}$ \\
\hline \multirow{4}{*}{ 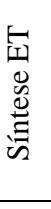 } & OsACO3 ACC oxydase & LOC_Os09g27750 & yes & $-1,40637$ & yes & $-1,36816$ & yes & $-1,55895$ & no & 0,03822 & no & $-0,15258$ & no & $-0,19079$ \\
\hline & OsACO5 ACC oxydase & LOC_Os05g05680 & no & $-0,55325$ & yes & $-1,36026$ & no & 0,18823 & no & $-0,80702$ & no & 0,74148 & yes & 1,54850 \\
\hline & OsACO7 ACC oxydase & LOC_Os01g39860 & yes & 2,15657 & no & 1,04013 & yes & 2,52130 & no & $-1,11644$ & no & 0,36473 & yes & 1,48117 \\
\hline & OsACS5 ACC synthase & LOC_Os01g09700 & yes & $-4,07224$ & yes & $-3,94518$ & yes & $-1,38810$ & no & 0,12707 & yes & 2,68414 & yes & 2,55708 \\
\hline \multirow{6}{*}{ 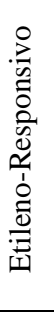 } & EBF1 EIN3-BINDING F-BOX & LOC_Os06g40360 & yes & $-1,19616$ & no & $-0,66440$ & no & $-0,30965$ & no & 0,53177 & yes & 0,88652 & no & 0,35475 \\
\hline & EBF2 EIN3-BINDING F-BOX & LOC_Os02g10700 & yes & $-1,32652$ & no & $-0,64020$ & no & $-0,44232$ & no & 0,68632 & no & 0,88420 & no & 0,19788 \\
\hline & OsERF3 Ethylene response TF & LOC_Os01g58420 & yes & $-1,08277$ & yes & $-0,90144$ & no & $-0,40895$ & no & 0,18133 & no & 0,67382 & no & 0,49249 \\
\hline & OsERF93 Ethylene-responsive TF & LOC_Os04g46220 & yes & $-1,36781$ & yes & $-1,02598$ & yes & $-1,38592$ & no & 0,34184 & no & $-0,01811$ & no & $-0,35994$ \\
\hline & OsERF91 Ethylene-responsive TF & LOC_Os02g43790 & yes & $-2,02052$ & yes & $-1,90522$ & no & $-0,70392$ & no & 0,11529 & yes & 1,31659 & yes & 1,20130 \\
\hline & OsERF101 Ethylene-responsive TF & LOC_Os04g32620 & yes & 1,20858 & yes & 1,34435 & yes & 1,01498 & no & 0,13577 & no & $-0,19360$ & no & $-0,32937$ \\
\hline
\end{tabular}
FC: fold change. 
TABELA 5. Genes diferencialmente expressos (DEG) relacionados proteínas relacionadas à patogênese (PRP).

\begin{tabular}{|c|c|c|c|c|c|c|c|c|c|c|c|c|c|}
\hline \multirow[b]{2}{*}{ Anotação } & \multirow[b]{2}{*}{ Gene ID } & \multicolumn{2}{|c|}{ H2O-AVR } & \multicolumn{2}{|c|}{ H2O-PGPR } & \multicolumn{2}{|c|}{ H2O-VIR } & \multicolumn{2}{|c|}{ AVR-PGPR } & \multicolumn{2}{|c|}{ AVR-VIR } & \multicolumn{2}{|c|}{ PGPR-VIR } \\
\hline & & DEG & $\mathrm{FC}$ & DEG & $\mathrm{FC}$ & DEG & $\mathrm{FC}$ & DEG & $\mathrm{FC}$ & DEG & $\mathrm{FC}$ & DEG & $\mathrm{FC}$ \\
\hline B-1, 3-glucanase 10 & LOC_Os01g51570 & yes & $-1,21035$ & yes & $-1,26831$ & no & $-0,28917$ & no & $-0,05796$ & no & 0,92118 & yes & 0,97914 \\
\hline B-1,3- endoglucanase GV & LOC_Os01g71810 & yes & 2,36491 & no & 0,29159 & no & 1,48634 & yes & $-2,07332$ & no & $-0,87857$ & no & 1,19475 \\
\hline B-1,3-endoglucosidase & LOC_Os02g04670 & yes & 1,39523 & no & 1,12080 & yes & 1,24522 & no & $-0,27443$ & no & $-0,15001$ & no & 0,12442 \\
\hline B-1,3-endoglucosidase & LOC_Os07g32600 & yes & 1,67937 & no & 1,18620 & no & 1,13471 & no & $-0,49317$ & no & $-0,54467$ & no & $-0,05150$ \\
\hline B-1,3-endoglucosidase & LOC_Os07g35560 & yes & $-1,24801$ & yes & $-1,47356$ & no & $-0,12795$ & no & $-0,22555$ & yes & 1,12006 & yes & 1,34561 \\
\hline B-1,3-endoglucosidase & LOC_Os09g09980 & yes & 2,06265 & yes & 1,96841 & yes & 1,94231 & no & $-0,09424$ & no & $-0,12034$ & no & $-0,02610$ \\
\hline B-1,3-endoglucosidase & LOC_Os11g36940 & yes & 2,73427 & yes & 3,00828 & yes & 2,55546 & no & 0,27401 & no & $-0,17881$ & no & $-0,45282$ \\
\hline B-1,3-glucanase & LOC_Os01g71820 & yes & 2,46108 & yes & 2,53004 & yes & 2,47646 & no & 0,06897 & no & 0,01538 & no & $-0,05358$ \\
\hline B-1,3-glucanase-like protein & LOC_Os03g46660 & no & 0,86856 & yes & 0,96159 & no & 0,60843 & no & 0,09303 & no & $-0,26013$ & no & $-0,35316$ \\
\hline OsEGL2 Endo-( 1,$3 ; 1,4)$-beta-glucanase 2 & LOC_Os05g31140 & no & $-0,45585$ & no & $-0,25099$ & yes & $-1,30800$ & no & 0,20486 & no & $-0,85215$ & yes & $-1,05701$ \\
\hline OsGLN1 B-1, 3-endoglucanase 1 & LOC_Os01g71474 & yes & 2,25525 & no & 1,36849 & yes & 1,90837 & no & $-0,88676$ & no & $-0,34687$ & no & 0,53988 \\
\hline OsGNS9 B-1, 3-glucanase 9 & LOC_Os01g71830 & yes & 2,75064 & yes & 2,70037 & yes & 3,01429 & no & $-0,05027$ & no & 0,26365 & no & 0,31392 \\
\hline OsPR2 B-1,3-glucanase & LOC_Os02g53200 & yes & 1,29471 & no & 0,71721 & no & 0,88491 & no & $-0,57751$ & no & $-0,40981$ & no & 0,16770 \\
\hline Chitinase Clas III & LOC_Os11g47600 & yes & 2,52346 & no & 1,04387 & yes & 2,31595 & yes & $-1,47959$ & no & $-0,20752$ & yes & 1,27208 \\
\hline Chitinase Class III & LOC_Os11g47500 & yes & 1,75465 & yes & 1,84648 & yes & 1,60490 & no & 0,09182 & no & $-0,14975$ & no & $-0,24158$ \\
\hline CHIT1 & LOC_Os06g51060 & yes & 1,33423 & yes & 1,13065 & yes & 1,35365 & no & $-0,20358$ & no & 0,01943 & no & 0,22300 \\
\hline CHIT2 & LOC_Os04g41620 & yes & 1,32016 & yes & 1,61988 & yes & 1,14625 & no & 0,29972 & no & $-0,17391$ & no & $-0,47363$ \\
\hline CHIT3 & LOC_Os06g51050 & yes & 2,39048 & no & 1,42739 & no & 1,79135 & no & $-0,96308$ & no & $-0,59913$ & no & 0,36396 \\
\hline CHIT5 & LOC_Os04g41680 & yes & 1,31458 & yes & 1,66361 & yes & 1,30466 & no & 0,34903 & no & $-0,00992$ & no & $-0,35895$ \\
\hline CHT8 & LOC_Os10g39680 & yes & 1,66946 & no & 0,88997 & yes & 2,04146 & no & $-0,77949$ & no & 0,37200 & yes & 1,15149 \\
\hline CHIT9 & LOC_Os05g33140 & yes & 2,80389 & no & 2,56298 & no & 2,13050 & no & $-0,24092$ & no & $-0,67340$ & no & $-0,43248$ \\
\hline CHIT13 & LOC_Os09g32080 & yes & 2,50306 & yes & 1,93080 & yes & 2,26750 & no & $-0,57225$ & no & $-0,23556$ & no & 0,33670 \\
\hline OsPR4b Chitinase Activity & LOC_Os11g37960 & yes & 1,74990 & no & 1,00966 & yes & 1,56262 & no & $-0,74025$ & no & $-0,18728$ & no & 0,55296 \\
\hline OsPR1a & LOC_Os07g03730 & yes & $-1,00699$ & no & $-0,78533$ & no & $-0,57659$ & no & 0,22166 & no & 0,43040 & no & 0,20875 \\
\hline OsPR1b & LOC_Os01g28450 & no & $-0,01347$ & no & 0,13898 & yes & 1,13920 & no & 0,15245 & yes & 1,15267 & yes & 1,00022 \\
\hline
\end{tabular}




\begin{tabular}{|c|c|c|c|c|c|c|c|c|c|c|c|c|c|}
\hline OsPR5 Alpha-amylase/trypsin inhibitor & LOC_Os03g45960 & yes & 1,91788 & yes & 1,89502 & yes & 1,74998 & no & $-0,02286$ & no & $-0,16790$ & no & $-0,14504$ \\
\hline Sci1 PR6 & LOC_Os12g25090 & yes & 1,92920 & yes & 2,45164 & yes & 2,06427 & no & 0,52244 & no & 0,13507 & no & $-0,38738$ \\
\hline PR10 & LOC_Os12g36860 & no & 0,27198 & no & 0,71556 & yes & 1,46646 & no & 0,44358 & no & 1,19448 & no & 0,75090 \\
\hline OsPR10a PBZ11 & LOC_Os12g36830 & no & 0,20646 & no & 0,25120 & no & 0,87882 & yes & 0,92972 & yes & 1,32787 & yes & 1,36448 \\
\hline OsPR10B PBZ1 & LOC_Os12g36850 & no & 0,55066 & yes & 1,19672 & yes & 1,55768 & no & 0,64605 & yes & 1,00702 & no & 0,36097 \\
\hline Peroxidase precursor & LOC_Os04g51300 & no & $-0,86988$ & yes & $-1,51822$ & no & $-0,78989$ & no & $-0,64834$ & no & 0,07999 & no & 0,72832 \\
\hline POX1 class III & LOC_Os05g41990 & yes & 3,06950 & yes & 3,10051 & yes & 2,87936 & no & 0,03102 & no & $-0,19014$ & no & $-0,22115$ \\
\hline PRX4 class III & LOC_Os01g16450 & yes & 1,59807 & yes & 1,65068 & yes & 2,07687 & no & 0,05260 & no & 0,47880 & no & 0,42619 \\
\hline POX5.1 class III & LOC_Os07g48040 & yes & $-2,30900$ & yes & $-2,32541$ & no & $-0,06553$ & no & $-0,01641$ & yes & 2,24347 & yes & 2,25989 \\
\hline POX8.1 class III & LOC_Os07g48010 & no & $-1,46551$ & yes & $-1,78676$ & no & $-0,91988$ & no & $-0,32125$ & no & 0,54564 & no & 0,86689 \\
\hline PRX precursor & LOC_Os01g22249 & yes & $-2,21569$ & yes & $-3,53941$ & no & $-0,71512$ & no & $-1,32372$ & no & 1,50057 & yes & 2,82429 \\
\hline PRX precursor & LOC_Os01g28030 & yes & 1,73406 & yes & 1,30314 & yes & 1,50083 & no & $-0,43092$ & no & $-0,23323$ & no & 0,19769 \\
\hline PRX11 class III & LOC_Os01g19020 & no & 0,88525 & no & 0,22485 & no & 0,85088 & no & $-0,66040$ & no & $-0,03437$ & no & 0,62603 \\
\hline PRX16 class III & LOC_Os01g22370 & yes & 2,05234 & yes & 1,83084 & yes & 1,81426 & no & $-0,22150$ & no & $-0,23807$ & no & $-0,01657$ \\
\hline PRX22, class III & LOC_Os01g73200 & yes & $-1,47434$ & yes & $-2,11782$ & no & 0,12520 & no & $-0,64348$ & yes & 1,59953 & yes & 2,24301 \\
\hline PRX26 class III & LOC_Os02g14170 & yes & 1,60379 & yes & 1,27485 & no & 1,04579 & no & $-0,32894$ & no & $-0,55801$ & no & $-0,22907$ \\
\hline PRX29 class III & LOC_Os02g14440 & yes & $-2,64842$ & yes & $-2,89885$ & yes & $-1,42170$ & no & $-0,25043$ & yes & 1,22672 & yes & 1,47715 \\
\hline PRX32 class III & LOC_Os02g58720 & yes & 2,15293 & yes & 1,45555 & yes & 1,84618 & no & $-0,69737$ & no & $-0,30675$ & no & 0,39062 \\
\hline PRX33 class III & LOC_Os03g02920 & yes & 1,43224 & yes & 1,21946 & yes & 1,58275 & no & $-0,21278$ & no & 0,15052 & no & 0,36330 \\
\hline PRX39 class III & LOC_Os03g13200 & yes & 3,31846 & yes & 2,61974 & yes & 2,85189 & no & $-0,69872$ & no & $-0,46657$ & no & 0,23215 \\
\hline PRX45 class III & LOC_Os03g25330 & yes & 2,57656 & yes & 1,93024 & yes & 1,95564 & no & $-0,64633$ & no & $-0,62093$ & no & 0,02540 \\
\hline PRX51, class III & LOC_Os03g55420 & yes & 1,58511 & no & 1,27135 & no & 1,30470 & no & $-0,31376$ & no & $-0,28041$ & no & 0,03335 \\
\hline PRX59 class III & LOC_Os04g59150 & yes & $-1,58544$ & yes & $-1,34419$ & no & $-0,40231$ & no & 0,24125 & yes & 1,18313 & yes & 0,94188 \\
\hline PRX61 class III & LOC_Os04g59190 & no & 0,95913 & yes & 1,42439 & no & 0,48421 & no & 0,46526 & no & $-0,47492$ & no & $-0,94018$ \\
\hline PRX62 class III & LOC_Os04g59200 & yes & $-2,37540$ & yes & $-2,44490$ & no & $-0,81560$ & no & $-0,06951$ & yes & 1,55980 & yes & 1,62931 \\
\hline PRX63 class III & LOC_Os04g59210 & yes & $-1,31645$ & yes & $-1,38543$ & no & $-0,91293$ & no & $-0,06898$ & no & 0,40352 & no & 0,47250 \\
\hline PRX65 class III & LOC_Os05g04380 & yes & 2,17184 & yes & 1,77567 & yes & 1,91975 & no & $-0,39617$ & no & $-0,25210$ & no & 0,14407 \\
\hline PRX71 class III & LOC_Os05g04500 & yes & 2,64029 & yes & 2,36325 & yes & 2,16255 & no & $-0,27704$ & no & $-0,47773$ & no & $-0,20070$ \\
\hline
\end{tabular}




\begin{tabular}{|c|c|c|c|c|c|c|c|c|c|c|c|c|c|}
\hline PRX72 class III & LOC_Os05g06970 & yes & 2,38710 & yes & 2,81913 & yes & 1,74046 & no & 0,43202 & no & $-0,64665$ & no & $-1,07867$ \\
\hline PRX77 class III & LOC_Os06g16350 & yes & 3,53625 & yes & 3,00207 & yes & 3,40916 & no & $-0,53417$ & no & $-0,12709$ & no & 0,40709 \\
\hline PRX78 class III & LOC_Os06g20150 & yes & $-1,61012$ & yes & $-1,62692$ & no & $-0,57486$ & no & $-0,01680$ & no & 1,03526 & no & 1,05206 \\
\hline PRX89 class III & LOC_Os06g46799 & yes & 2,15615 & yes & 1,94379 & yes & 1,73216 & no & $-0,21236$ & no & $-0,42399$ & no & $-0,21163$ \\
\hline PRX91 class III & LOC_Os06g48020 & yes & 2,09201 & yes & 2,67580 & no & 1,28043 & no & 0,58379 & no & $-0,81158$ & yes & $-1,39536$ \\
\hline PRX97 class III & LOC_Os07g01370 & yes & 2,94031 & yes & 2,34454 & yes & 2,57986 & no & $-0,59577$ & no & $-0,36045$ & no & 0,23531 \\
\hline PRX109 class III & LOC_Os07g47990 & no & $-1,29978$ & yes & $-1,81951$ & no & $-0,68625$ & no & $-0,51973$ & no & 0,61353 & no & 1,13326 \\
\hline PRX115 class III & LOC_Os07g48060 & yes & 1,68838 & no & 1,10908 & yes & 1,39910 & no & $-0,57929$ & no & $-0,28928$ & no & 0,29002 \\
\hline PRX117 class III & LOC_Os08g02110 & no & $-1,40956$ & yes & $-2,51455$ & no & $-0,33174$ & no & $-1,10499$ & no & 1,07782 & yes & 2,18281 \\
\hline PRX122, class III & LOC_Os09g29490 & yes & $-1,41655$ & yes & $-1,25625$ & no & $-0,48565$ & no & 0,16030 & no & 0,93090 & no & 0,77060 \\
\hline PRX123 class III & LOC_Os09g32964 & yes & 2,39489 & yes & 1,92842 & yes & 1,70352 & no & $-0,46648$ & no & $-0,69138$ & no & $-0,22490$ \\
\hline PRX125 class III & LOC_Os10g02040 & yes & 1,08317 & no & 0,66807 & yes & 1,07309 & no & $-0,41510$ & no & $-0,01008$ & no & 0,40503 \\
\hline PRX132 class III & LOC_Os11g10460 & yes & 3,32826 & yes & 3,02896 & yes & 3,07646 & no & $-0,29930$ & no & $-0,25181$ & no & 0,04750 \\
\hline PRX138 class III & LOC_Os12g34524 & yes & 2,54376 & yes & 2,27448 & yes & 2,36420 & no & $-0,26928$ & no & $-0,17956$ & no & 0,08972 \\
\hline AOX1a alternative oxidase-1a & LOC_Os04g51150 & no & 0,83291 & no & 0,62035 & yes & 0,92205 & no & $-0,21256$ & no & 0,08914 & no & 0,30170 \\
\hline OsAPX3 ascorbate peroxidase 3 & LOC_Os04g14680 & yes & 2,24821 & no & 1,49133 & yes & 2,00048 & no & $-0,75688$ & no & $-0,24774$ & no & 0,50914 \\
\hline OsAPX7 ascorbate peroxidase 7 & LOC_Os04g35520 & no & 0,95422 & no & 0,48991 & yes & 1,01581 & no & $-0,46430$ & no & 0,06159 & no & 0,52590 \\
\hline OsAPX8 ascorbate peroxidase 8 & LOC_Os02g34810 & yes & $-1,16271$ & yes & $-1,45635$ & no & $-0,93537$ & no & $-0,29364$ & no & 0,22734 & no & 0,52098 \\
\hline OsCATB Catalase isozyme B & LOC_Os06g51150 & no & 0,80670 & yes & 0,96719 & no & 0,51894 & no & 0,16048 & no & $-0,28777$ & no & $-0,44825$ \\
\hline OsRbohC Respiratory Burst Oxidase Homolog C & LOC_Os05g45210 & no & 1,00415 & no & 0,96806 & yes & 1,37071 & no & $-0,03610$ & no & 0,36656 & no & 0,40266 \\
\hline OsRbohH Respiratory Burst Oxidase Homolog H & LOC_Os12g35610 & no & 2,09205 & no & 2,09316 & yes & 2,05553 & no & 0,00112 & no & $-0,03651$ & No & $-0,03763$ \\
\hline
\end{tabular}
FC: fold change. 
TABELA 6. Genes diferencialmente expressos (DEG) da família de fatores de transcrição WRKY.

\begin{tabular}{|c|c|c|c|c|c|c|c|c|c|c|c|c|c|}
\hline \multirow[b]{2}{*}{ Anotação } & \multirow[b]{2}{*}{ Gene ID } & \multicolumn{2}{|c|}{ H2O-AVR } & \multicolumn{2}{|c|}{ H2O-PGPR } & \multicolumn{2}{|c|}{ H2O-VIR } & \multicolumn{2}{|c|}{ AVR-PGPR } & \multicolumn{2}{|c|}{ AVR-VIR } & \multicolumn{2}{|c|}{ PGPR-VIR } \\
\hline & & DEG & $\mathrm{FC}$ & DEG & $\mathrm{FC}$ & DEG & $\mathrm{FC}$ & DEG & $\mathrm{FC}$ & DEG & $\mathrm{FC}$ & DEG & $\mathrm{FC}$ \\
\hline OsWRKY4 & LOC_Os06g44010 & yes & $-1,83049$ & yes & $-2,02189$ & no & $-0,16877$ & no & $-0,19140$ & yes & 1,66172 & yes & 1,85312 \\
\hline OsWRKY17 & LOC_Os02g53100 & yes & 2,44555 & yes & 2,59832 & yes & 2,05925 & no & 0,15278 & no & $-0,38629$ & no & $-0,53907$ \\
\hline OsWRKY18 & LOC_Os02g08440 & yes & $-2,80103$ & yes & $-2,73397$ & yes & $-1,28228$ & no & 0,06706 & yes & 1,51875 & yes & 1,45169 \\
\hline OsWRKY22 & LOC_Os01g61080 & yes & $-1,78758$ & yes & $-2,28387$ & no & $-0,41491$ & no & $-0,49629$ & yes & 1,37267 & yes & 1,86897 \\
\hline OsWRKY31 & LOC_Os01g53260 & yes & 1,77129 & yes & 2,03111 & yes & 1,66821 & no & 0,25981 & no & $-0,10308$ & no & $-0,36290$ \\
\hline OsWRKY46 & LOC_Os05g46020 & yes & $-1,14194$ & yes & $-1,12337$ & no & $-0,13591$ & no & 0,01858 & yes & 1,00603 & no & 0,98746 \\
\hline OsWRKY63 & LOC_Os05g09020 & yes & $-1,45527$ & yes & $-1,17784$ & no & $-0,47963$ & no & 0,27743 & yes & 0,97564 & no & 0,69821 \\
\hline OsWRKY69 & LOC_Os05g39720 & no & $-0,56447$ & yes & $-1,22390$ & no & 0,49802 & no & $-0,65943$ & yes & 1,06250 & yes & 1,72193 \\
\hline OsWRKY58 & LOC_Os09g25060 & no & $-0,73446$ & no & $-0,22925$ & yes & $-1,16555$ & no & 0,50522 & no & $-0,43109$ & yes & $-0,93631$ \\
\hline OsWRKY42 & LOC_Os04g21950 & yes & $-1,01826$ & no & $-0,81993$ & no & $-0,63394$ & no & 0,19833 & no & 0,38431 & no & 0,18598 \\
\hline OsWRKY60 & LOC_Os05g50700 & yes & $-2,27437$ & yes & $-2,27415$ & no & $-1,19011$ & no & 0,00022 & no & 1,08425 & no & 1,08403 \\
\hline OsWRKY61 & LOC_Os05g27730 & yes & $-2,01679$ & yes & $-1,48539$ & yes & $-1,13918$ & no & 0,53141 & no & 0,87761 & no & 0,34620 \\
\hline OsWRKY96 & LOC_Os01g14440 & yes & $-1,04951$ & no & $-0,87226$ & no & $-0,39531$ & no & 0,17725 & no & 0,65420 & no & 0,47695 \\
\hline
\end{tabular}

FC: fold change. 
TABELA 7. Genes diferencialmente expressos (DEG) da família proteínas quinases ativadas por mitógenos (MAPK, MAPKK e MAPKKK).

\begin{tabular}{|c|c|c|c|c|c|c|c|c|c|c|c|c|c|}
\hline \multirow[b]{2}{*}{ Anotação } & \multirow[b]{2}{*}{ Gene ID } & \multicolumn{2}{|c|}{ H2O-AVR } & \multicolumn{2}{|c|}{ H2O-PGPR } & \multicolumn{2}{|c|}{ H2O-VIR } & \multicolumn{2}{|c|}{ AVR-PGPR } & \multicolumn{2}{|c|}{ AVR-VIR } & \multicolumn{2}{|c|}{ PGPR-VIR } \\
\hline & & DEG & FC & DEG & $\mathrm{FC}$ & DEG & $\mathrm{FC}$ & DEG & $\mathrm{FC}$ & DEG & $\mathrm{FC}$ & DEG & $\mathrm{FC}$ \\
\hline MAPK1 & LOC_Os08g42700 & yes & $-1,37432$ & no & $-0,72751$ & yes & $-1,20552$ & no & 0,64681 & no & 0,16880 & no & $-0,47801$ \\
\hline MAPK5 & LOC_Os03g17700 & yes & $-1,39612$ & yes & $-1,44889$ & no & $-0,32213$ & no & $-0,05277$ & yes & 1,07399 & yes & 1,12676 \\
\hline MAPK10 & LOC_Os01g43910 & yes & 1,52699 & yes & 1,37009 & yes & 1,18199 & no & $-0,15690$ & no & $-0,34499$ & no & $-0,18809$ \\
\hline MAPKK4 & LOC_Os02g54600 & yes & $-1,62786$ & yes & $-1,10022$ & no & $-0,70848$ & no & 0,52764 & no & 0,91938 & no & 0,39174 \\
\hline MAPKK10-2 & LOC_Os03g12390 & yes & $-1,30029$ & yes & $-1,10877$ & yes & $-1,41147$ & no & 0,19151 & no & $-0,11118$ & no & $-0,30270$ \\
\hline MAPKKK3 & LOC_Os02g32610 & yes & $-1,61140$ & yes & $-1,22874$ & yes & $-0,87212$ & no & 0,38266 & no & 0,73928 & no & 0,35662 \\
\hline MAPKKK20 & LOC_Os07g38530 & yes & $-0,84621$ & no & $-0,84033$ & no & $-0,63282$ & no & 0,00588 & no & 0,21339 & no & 0,20751 \\
\hline MAPKKK30 & LOC_Os02g02780 & yes & 1,71473 & yes & 1,74678 & yes & 1,22123 & no & 0,03205 & no & $-0,49350$ & no & $-0,52555$ \\
\hline MAPKKK62 & LOC_Os01g50420 & yes & $-2,93351$ & yes & $-2,29300$ & no & $-0,97435$ & no & 0,64051 & yes & 1,95916 & no & 1,31865 \\
\hline MAPKKK70 & LOC_Os01g50410 & yes & $-2,66003$ & yes & $-2,18934$ & yes & $-1,65682$ & no & 0,47069 & no & 1,00321 & no & 0,53252 \\
\hline MAPKKK74 & LOC_Os01g66860 & yes & 2,66536 & yes & 2,50577 & yes & 2,64350 & no & $-0,15958$ & no & $-0,02186$ & no & 0,13773 \\
\hline
\end{tabular}

FC: fold change. 
TABELA 8. Genes diferencialmente expressos (DEG) relacionados com genes de resistência (R).

\begin{tabular}{|c|c|c|c|c|c|c|c|c|c|c|c|c|c|}
\hline \multirow[b]{2}{*}{ Anotação } & \multirow[b]{2}{*}{ Gene ID } & \multicolumn{2}{|c|}{ H2O-AVR } & \multicolumn{2}{|c|}{ H2O-PGPR } & \multicolumn{2}{|c|}{ H2O-VIR } & \multicolumn{2}{|c|}{ AVR-PGPR } & \multicolumn{2}{|c|}{ AVR-VIR } & \multicolumn{2}{|c|}{ PGPR-VIR } \\
\hline & & DEG & $\mathrm{FC}$ & DEG & $\mathrm{FC}$ & DEG & $\mathrm{FC}$ & DEG & $\mathrm{FC}$ & DEG & $\mathrm{FC}$ & DEG & $\mathrm{FC}$ \\
\hline Disease resistance RPP13-like protein 1 & LOC_Os10g04090 & no & 0,78275 & no & 0,81283 & yes & 1,20561 & no & 0,03008 & no & 0,42286 & no & 0,39278 \\
\hline Leucine-rich repeat resistance protein & LOC_Os03g11340 & yes & 1,27189 & no & 0,83419 & yes & 1,27887 & no & $-0,43770$ & no & 0,00698 & no & 0,44468 \\
\hline OsDR8 & LOC_Os07g34570 & yes & 1,02973 & no & 0,81063 & no & 0,55667 & no & $-0,21910$ & no & $-0,47306$ & no & $-0,25396$ \\
\hline OsMT2b & LOC_Os05g02070 & yes & 1,58601 & yes & 1,37504 & no & 0,97344 & no & $-0,21097$ & no & $-0,61256$ & no & $-0,40160$ \\
\hline OsXB15 & LOC_Os03g60650 & yes & $-1,13752$ & yes & $-1,12879$ & no & $-0,38618$ & no & 0,00873 & no & 0,75134 & no & 0,74261 \\
\hline RBBI2-1 & LOC_Os01g03320 & yes & $-1,65909$ & yes & $-1,35395$ & yes & $-1,53562$ & no & 0,30514 & no & 0,12347 & no & $-0,18167$ \\
\hline RBBI2-2 & LOC_Os01g03310 & yes & $-1,21261$ & yes & $-1,08628$ & yes & $-1,12591$ & no & 0,12633 & no & 0,08670 & no & $-0,03962$ \\
\hline NB-ARC/LRR disease resistance protein & LOC_Os03g14900 & yes & 1,24126 & no & 1,03509 & no & 1,11156 & no & $-0,20617$ & no & $-0,12970$ & no & 0,07647 \\
\hline NBS-LRR Pi2/9 homolog & LOC_Os06g17970 & no & $-0,69782$ & yes & $-0,91847$ & no & $-0,72778$ & no & $-0,22065$ & no & $-0,02996$ & no & 0,19069 \\
\hline PIBH8 NB-ARC domain & LOC_Os08g42700 & yes & $-1,37432$ & no & $-0,72751$ & yes & $-1,20552$ & no & 0,64681 & no & 0,16880 & no & $-0,47801$ \\
\hline RGA3 NB-ARC domain & LOC_Os06g47800 & yes & 1,86137 & yes & 1,70733 & yes & 1,91901 & no & $-0,15404$ & no & 0,05764 & no & 0,21168 \\
\hline XA13 & LOC_Os08g42350 & yes & 2,84240 & no & 1,56029 & yes & 2,20710 & no & $-1,28210$ & no & $-0,63529$ & no & 0,64681 \\
\hline XA21 & LOC_Os11g35500 & yes & 1,84396 & no & 1,37894 & yes & 1,99502 & no & $-0,46502$ & no & 0,15106 & no & 0,61608 \\
\hline XB3 & LOC_Os05g02130 & no & 0,70456 & yes & 0,96170 & no & 0,65094 & no & 0,25714 & no & $-0,05362$ & no & $-0,31076$ \\
\hline
\end{tabular}

FC: fold change. 
TABELA 9. Genes diferencialmente expressos (DEG) relacionados com síntese de fitoalexinas.

\begin{tabular}{|c|c|c|c|c|c|c|c|c|c|c|c|c|c|}
\hline \multirow[b]{2}{*}{ Anotação } & \multirow[b]{2}{*}{ Gene ID } & \multicolumn{2}{|c|}{ H2O-AVR } & \multicolumn{2}{|c|}{ H2O-PGPR } & \multicolumn{2}{|c|}{ H2O-VIR } & \multicolumn{2}{|c|}{ AVR-PGPR } & \multicolumn{2}{|c|}{ AVR-VIR } & \multicolumn{2}{|c|}{ PGPR-VIR } \\
\hline & & DEG & FC & DEG & FC & DEG & FC & DEG & FC & DEG & $\mathrm{FC}$ & DEG & $\mathrm{FC}$ \\
\hline Isoflavone Maackiain biosynthesis & LOC_Os01g01650 & yes & 2,46475 & yes & 1,68552 & yes & 2,18617 & no & $-0,77923$ & no & $-0,27858$ & no & 0,50065 \\
\hline Isoflavone Maackiain/Medicarpin biosynt. & LOC_Os01g01660 & yes & 2,22962 & yes & 1,23847 & yes & 2,50434 & no & $-0,99116$ & no & 0,27472 & yes & 1,26587 \\
\hline OsKS7 rice ent-kaurene synthase 7 & LOC_Os02g36140 & no & 0,61063 & yes & 1,83657 & yes & 2,05357 & yes & 1,22594 & yes & 1,44294 & no & 0,21700 \\
\hline OsCPS2 & LOC_Os02g36210 & no & 0,34444 & yes & 1,93540 & yes & 2,63321 & no & 1,59097 & yes & 2,28877 & no & 0,69781 \\
\hline OsCPS4 & LOC_Os04g09900 & no & 0,73976 & no & 0,97390 & yes & 1,80346 & no & 0,23414 & yes & 1,06371 & no & 0,82956 \\
\hline OsMAS Momilactone A synthase 1 & LOC_Os04g09920 & no & 0,38628 & no & 0,66389 & yes & 1,87037 & no & 0,27761 & no & 1,48409 & no & 1,20647 \\
\hline OsMAS Momilactone A synthase & LOC_Os04g10010 & no & 1,11962 & no & 1,83186 & yes & 2,33691 & no & 0,71224 & no & 1,21729 & no & 0,50505 \\
\hline OsKS4 rice ent-kaurene synthase 4 & LOC_Os04g10060 & no & 1,00031 & yes & 2,72129 & yes & 2,41892 & yes & 1,72097 & no & 1,41861 & no & $-0,30236$ \\
\hline Momilactone biosynthesis Cyt P450 & LOC_Os04g10160 & no & 0,96044 & yes & 1,68475 & yes & 2,13741 & no & 0,72431 & no & 1,17697 & no & 0,45266 \\
\hline OsKO4 rice ent-kaurene oxidase 4 & LOC_Os06g37300 & yes & 1,74238 & yes & 2,37854 & yes & 3,17204 & no & 0,63616 & yes & 1,42966 & no & 0,79350 \\
\hline
\end{tabular}

FC: fold change. 
TABELA 10. Genes diferencialmente expressos (DEG) do citocromo P450.

\begin{tabular}{|c|c|c|c|c|c|c|c|c|c|c|c|c|}
\hline \multirow[b]{2}{*}{ Gene ID } & \multicolumn{2}{|c|}{ H2O-AVR } & \multicolumn{2}{|c|}{ H2O-PGPR } & \multicolumn{2}{|c|}{ H2O-VIR } & \multicolumn{2}{|c|}{ AVR-PGPR } & \multicolumn{2}{|c|}{ AVR-VIR } & \multicolumn{2}{|c|}{ PGPR-VIR } \\
\hline & DEG & $\mathrm{FC}$ & DEG & $\mathrm{FC}$ & DEG & FC & DEG & $\mathrm{FC}$ & DEG & FC & DEG & $\mathrm{FC}$ \\
\hline LOC_Os01g36294 & yes & 1,51726 & yes & 1,48641 & no & 0,62233 & no & $-0,03085$ & no & $-0,89493$ & no & $-0,86408$ \\
\hline LOC_Os02g02000 & yes & $-1,52089$ & yes & $-1,36349$ & yes & $-1,57421$ & no & 0,15739 & no & $-0,05332$ & no & $-0,21072$ \\
\hline LOC_Os02g02230 & no & 2,24210 & yes & 4,19875 & yes & 3,80368 & no & 1,95665 & no & 1,56158 & no & $-0,39506$ \\
\hline LOC_Os02g47470 & yes & $-2,68880$ & yes & $-2,22308$ & yes & $-0,95975$ & no & 0,46572 & yes & 1,72906 & yes & 1,26333 \\
\hline LOC_Os03g04660 & yes & 2,17713 & yes & 1,72261 & yes & 1,86172 & no & $-0,45452$ & no & $-0,31540$ & no & 0,13911 \\
\hline LOC_Os03g45619 & yes & 2,72587 & yes & 1,89996 & yes & 2,26166 & no & $-0,82591$ & no & $-0,46421$ & no & 0,36170 \\
\hline LOC_Os03g55800 & yes & $-1,75540$ & yes & $-2,02794$ & yes & $-1,26698$ & no & $-0,27253$ & no & 0,48843 & no & 0,76096 \\
\hline LOC_Os04g01140 & yes & 1,84209 & yes & 1,38433 & yes & 1,45835 & no & $-0,45776$ & no & $-0,38374$ & no & 0,07402 \\
\hline LOC_Os04g10160 & no & 0,96044 & yes & 1,68475 & yes & 2,13741 & no & 0,72431 & no & 1,17697 & no & 0,45266 \\
\hline LOC_Os04g47250 & yes & 2,51648 & yes & 2,36046 & yes & 2,48782 & no & $-0,15601$ & no & $-0,02866$ & no & 0,12735 \\
\hline LOC_Os05g33590 & yes & $-1,36132$ & yes & $-1,11991$ & no & $-0,86649$ & no & 0,24142 & no & 0,49483 & no & 0,25342 \\
\hline LOC_Os05g43910 & yes & $-1,31146$ & yes & $-1,42663$ & yes & $-1,28671$ & no & $-0,11517$ & no & 0,02475 & no & 0,13992 \\
\hline LOC_Os06g46680 & yes & 2,73314 & yes & 2,51642 & yes & 2,65783 & no & $-0,21672$ & no & $-0,07531$ & no & 0,14142 \\
\hline LOC_Os07g11739 & yes & 1,18059 & yes & 1,23503 & yes & 1,12857 & no & 0,05444 & no & $-0,05202$ & no & $-0,10646$ \\
\hline LOC_Os07g11870 & no & 2,12856 & yes & 4,02038 & yes & 4,17219 & yes & 1,89183 & yes & 2,04364 & no & 0,15181 \\
\hline LOC_Os07g23570 & yes & 1,58880 & yes & 1,47781 & yes & 1,32575 & no & $-0,11100$ & no & $-0,26305$ & no & $-0,15205$ \\
\hline LOC_Os07g44140 & yes & 1,24178 & yes & 1,20056 & yes & 1,28458 & no & $-0,04123$ & no & 0,04280 & no & 0,08403 \\
\hline LOC_Os08g16260 & yes & 2,67039 & yes & 2,04459 & yes & 2,62220 & no & $-0,62580$ & no & $-0,04819$ & no & 0,57761 \\
\hline LOC_Os08g39730 & yes & 1,39358 & yes & 1,15768 & yes & 1,18658 & no & $-0,23591$ & no & $-0,20701$ & no & 0,02890 \\
\hline LOC_Os09g08920 & no & 0,98877 & no & 2,10067 & no & 1,39047 & no & 1,11189 & no & 0,40169 & no & $-0,71020$ \\
\hline LOC_Os09g08990 & yes & 2,70243 & yes & 2,39998 & yes & 2,27117 & no & $-0,30245$ & no & $-0,43126$ & no & $-0,12881$ \\
\hline LOC_Os09g35940 & no & $-1,05281$ & yes & $-1,51425$ & no & $-0,80987$ & no & $-0,46144$ & no & 0,24294 & no & 0,70438 \\
\hline LOC_Os10g16974 & yes & 2,03922 & yes & 1,61848 & yes & 1,83368 & no & $-0,42074$ & no & $-0,20554$ & no & 0,21520 \\
\hline LOC_Os10g38110 & no & $-0,62285$ & yes & $-1,08679$ & no & $-0,72991$ & no & $-0,46394$ & no & $-0,10706$ & no & 0,35688 \\
\hline LOC_Os11g05380 & yes & $-3,43032$ & yes & $-3,39073$ & yes & $-2,36337$ & no & 0,03959 & no & 1,06695 & no & 1,02736 \\
\hline
\end{tabular}




\begin{tabular}{|c|c|c|c|c|c|c|c|c|c|c|c|c|}
\hline LOC_Os11g18570 & yes & 2,21784 & yes & 2,24788 & yes & 2,28565 & no & 0,03005 & no & 0,06782 & no & 0,03777 \\
\hline LOC_Os11g27730 & no & $-0,62807$ & yes & $-0,86729$ & no & $-0,47911$ & no & $-0,23922$ & no & 0,14896 & no & 0,38818 \\
\hline LOC_Os11g29290 & yes & $-2,45499$ & yes & $-2,83870$ & yes & $-1,49956$ & no & $-0,38371$ & no & 0,95543 & no & 1,33913 \\
\hline LOC_Os11g41710 & yes & $-2,42315$ & yes & $-1,93994$ & no & $-0,88482$ & no & 0,48321 & yes & 1,53833 & no & 1,05512 \\
\hline
\end{tabular}


TABELA 11. Genes diferencialmente expressos (DEG) envolvidos no crosstalk das vias hormonais.

\begin{tabular}{|c|c|c|c|c|c|c|c|c|c|c|c|c|c|}
\hline \multirow[b]{3}{*}{ Anotação } & \multirow[b]{3}{*}{ Gene ID } & \multirow{2}{*}{\multicolumn{2}{|c|}{ H2O-AVR }} & \multirow{2}{*}{\multicolumn{2}{|c|}{ H2O-PGPR }} & \multirow{2}{*}{\multicolumn{2}{|c|}{ H2O-VIR }} & \multirow{2}{*}{\multicolumn{2}{|c|}{ AVR-PGPR }} & \multirow{2}{*}{\multicolumn{2}{|c|}{ AVR-VIR }} & \multirow{2}{*}{\multicolumn{2}{|c|}{ PGPR-VIR }} \\
\hline & & & & & & & & & & & & & \\
\hline & & DEG & FC & DEG & FC & DEG & FC & DEG & FC & DEG & FC & DEG & FC \\
\hline OsNPR4 & LOC_Os01g61990 & yes & $-2,08764$ & yes & $-1,72222$ & no & $-0,65187$ & no & 0,36542 & yes & 1,43577 & yes & 1,07036 \\
\hline OsStr11 Sulfurtransferase 11 & LOC_Os02g49680 & no & $-0,71391$ & yes & $-1,12920$ & no & $-0,55542$ & no & $-0,41530$ & no & 0,15849 & no & 0,57379 \\
\hline SAM dependent carboxyl methyltransferase & LOC_Os06g20960 & no & 2,10950 & no & 0,46385 & yes & 2,72871 & no & $-1,64565$ & no & 0,61921 & yes & 2,26486 \\
\hline OsSLRL1 & LOC_Os07g46920 & no & $-0,97783$ & no & $-0,63341$ & yes & $-1,46562$ & no & 0,34442 & no & $-0,48779$ & no & $-0,83221$ \\
\hline
\end{tabular}
FC: fold change. 